Florida International University

FIU Digital Commons

$12-3-2018$

\title{
Genocide in the Modern Age: State-Society Relations in the Making of Mass Political Violence, 1900-2015
}

Zachary Karazsia

zkarazsia@georgiasouthern.edu

Follow this and additional works at: https://digitalcommons.fiu.edu/etd

Part of the Comparative Politics Commons, International Relations Commons, and the Other Political Science Commons

\section{Recommended Citation}

Karazsia, Zachary, "Genocide in the Modern Age: State-Society Relations in the Making of Mass Political Violence, 1900-2015" (2018). FIU Electronic Theses and Dissertations. 4068.

https://digitalcommons.fiu.edu/etd/4068

This work is brought to you for free and open access by the University Graduate School at FIU Digital Commons. It has been accepted for inclusion in FIU Electronic Theses and Dissertations by an authorized administrator of FIU Digital Commons. For more information, please contact dcc@fiu.edu. 


\title{
FLORIDA INTERNATIONAL UNIVERSITY
}

Miami, Florida

GENOCIDE IN THE MODERN AGE:

STATE-SOCIETY RELATIONS IN THE MAKING OF MASS POLITICAL VIOLENCE, 1900-2015

\author{
A dissertation submitted in partial fulfillment of \\ the requirements for the degree of \\ DOCTOR OF PHILOSOPHY \\ in \\ POLITICAL SCIENCE \\ by \\ Zachary A. Karazsia
}

2019 
To: Dean John F. Stack, Jr.

Steven J. Green School of International and Public Affairs

This dissertation, written by Zachary A. Karazsia, and entitled Genocide in the Modern Age: State-Society Relations in the Making of Mass Political Violence, 1900-2015, having been approved in respect to style and intellectual content, is referred to you for judgment.

We have read this dissertation and recommend that it be approved.

Hannibal Travis

Oren Stier

Richard S. Olsen

Harry D. Gould, Co-Major Professor

John F. Clark, Co-Major Professor

Date of Defense: December 3, 2018

The dissertation of Zachary A. Karazsia is approved.

Dean John F. Stack, Jr. Steven J. Green School of International and Public Affairs

Andrés G. Gil

Vice President for Research and Economic Development and Dean of the University Graduate School

Florida International University, 2019 
(C) Copyright 2019 by Zachary A. Karazsia

All rights reserved. 


\section{DEDICATION}

To my mom and dad, without your support, care, and love this would all have been in vain. Thank you for always believing in me. 


\section{ACKNOWLEDGMENTS}

I would like to thank my dissertation committee - chair John F. Clark, co-chair

Harry D. Gould, committee members Richard S. Olson, Oren Stier, and Hannibal Travis - for their patience, guidance, support, and encouragement. This has been a long,

arduous, and trying journey but I have only been able to reach this point with the delicate and sometimes firm guidance you all have provided. From the bottom of my heart, thank you! 


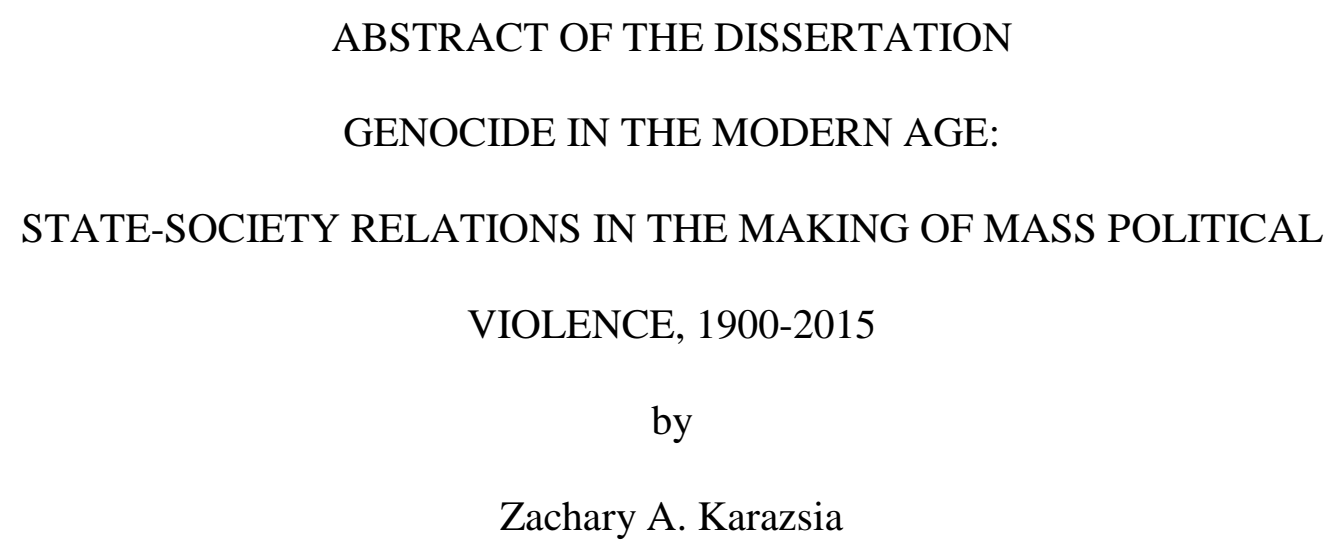

Florida International University, 2018

Miami, Florida

Professor John F. Clark, Co-Major Professor

Professor Harry D. Gould, Co-Major Professor

This dissertation presents a new conceptual framework for understanding genocide and mass political violence. I build upon existing theories of mass violence that take into account motivations for committing mass atrocities, combine these with the task of counting civilian casualties, and propose a new framework based on the perpetrators' socio-political standing in society. This model develops a four-part typology of perpetrators by examining the level of government participation and societal participation in the process of violence. Four patterns of perpetrators emerge from this deductive assessment of large-scale violence. These mass political violence perpetrator categories are: a) state perpetrators; b) state-society coalitions; c) state-sponsored groups; and d) non-state actors. Based on the evidence and analysis in this dissertation I found four central conclusions. First, perpetrator type implicitly limits the scope of violence and target group(s). Second, when assessing the severity and destructive power of each perpetrator category, we must use both absolute and relative thresholds. Neither on its 
own is sufficient for understanding why and how perpetrators target and eliminate vast segments of society. Third, based on this typological framework, there are variations between perpetrator categories (i.e., state perpetrators and state-society coalitions) and there is variation within each perpetrator category. The final conclusion is that scholars must question the so-called unitary role of the state when theorizing about genocide and mass political violence perpetrators. The role of state and society is not unitary nor as parsimonious as previous theories of mass violence suggest. 


\section{TABLE OF CONTENTS}

CHAPTER

PAGE

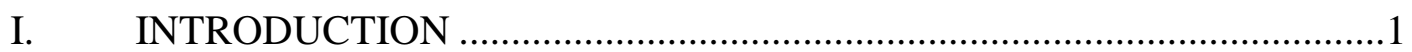

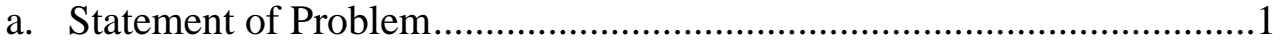

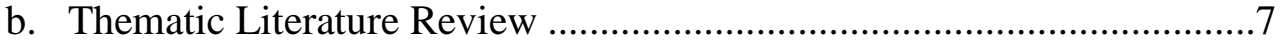

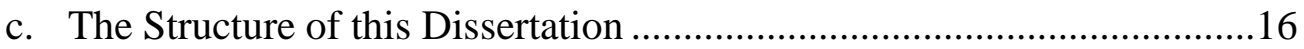

II. A CRIME BY MANY NAMES: MASS POLITICAL VIOLENCE AND

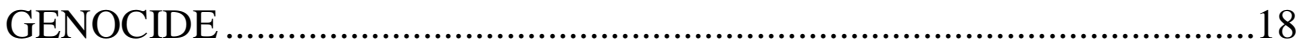

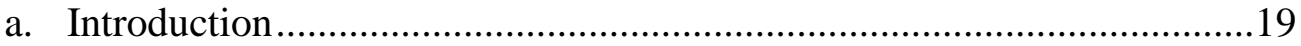

b. Raphael Lemkin: A New Perspective on an Old Crime .........................21

c. Problems and Pitfalls: Barriers to Explaining and Prosecuting the

Crime of Genocide ..............................................................................30

i. Problem 1: The Contested Meaning of "Intent" ...................31

ii. Problem 2: Who Counts? ......................................................34

iii. Problem 3: Thresholds and Scales of Violence .....................36

iv. Problem 4: Politicization of the "G-Word" ...........................37

v. Problem 5-6: Inside Baseball: Dilemmas in Adhering Too Rigorous, Scientific Standards in Genocide Research...........40

d. The Post-Lemkin Era: Terms and Categories ........................................43

i. First Wave: Changes Around the Edge: Alternative Definitions of "Genocide"

ii. Second Wave: Qualifications and Caveats: Sub-Categories of Genocide

iii. Third Wave: Discontent with "Tradition": Substitutive Terms for Genocide

e. What is Mass Political Violence?

III. THE CAUSES AND CONSEQUENCES OF MASS POLITICAL

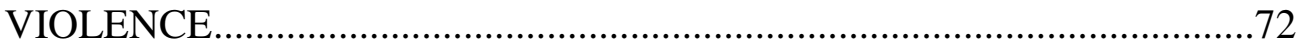

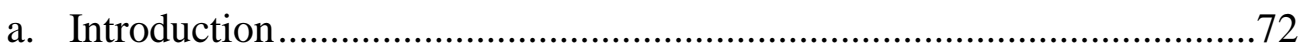

b. A Typology of Mass Political Violence..................................................76

i. Assumptions and Debates in Theory Building ...........................76

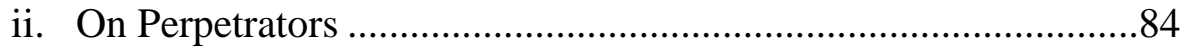

c. Four Modes of Mass Political Violence.................................................91

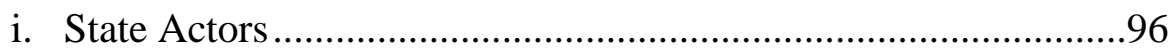

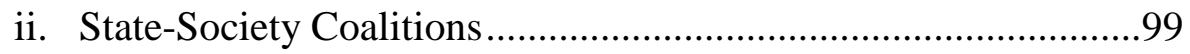

iii. State-Sponsored Groups...........................................................102

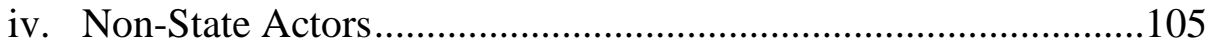

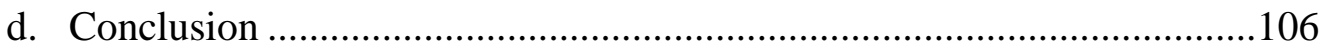


IV. STATE ACTORS AND MASS POLITICAL VIOLENCE ...........................108

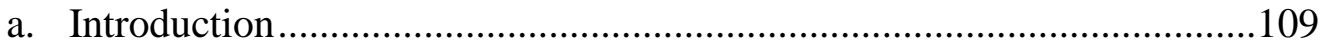

b. A Dynamic Structural Approach to State-Led Mass Political Violence...115

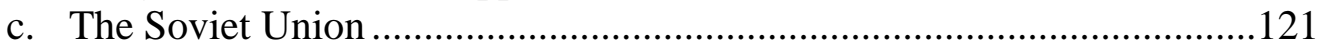

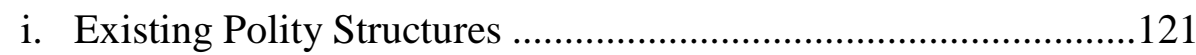

ii. Cycle of Violence ……………………….............................136

iii. Decision Points ..........................................................................138

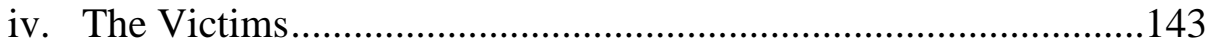

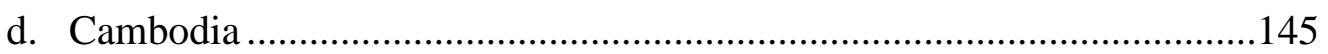

i. Existing Polity Structures ………………………………........145

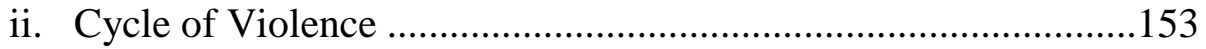

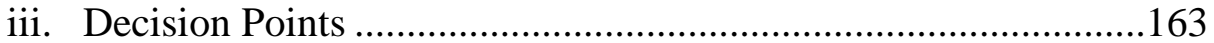

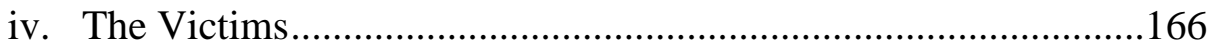

V. STATE-SOCIETY COALITIONS: THE HOLOCAUST AND

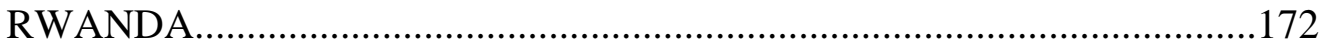

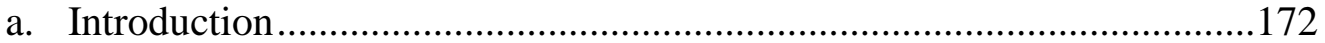

b. A Dynamic Structural Approach to State-Society Coalitions...................176

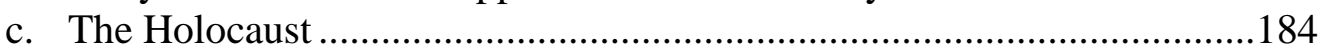

i. Existing Polity Structures …………………………………......186

ii. The "Ordinary Men" or "Willing Executioners" Debate..............197

iii. The Cycle of Violence .................................................................104

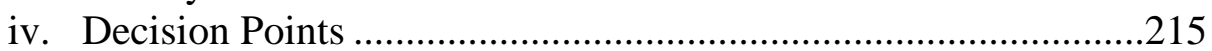

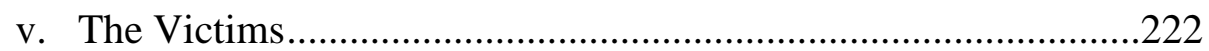

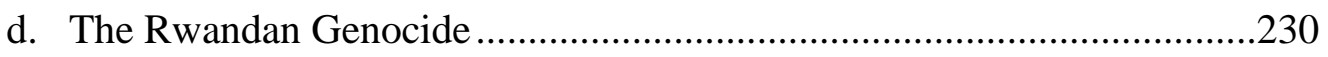

i. Existing Polity Structures .......................................................231

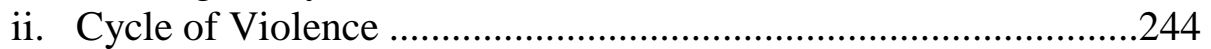

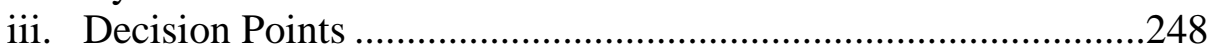

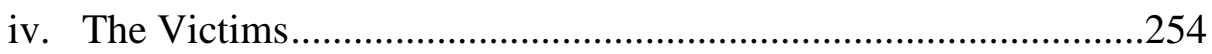

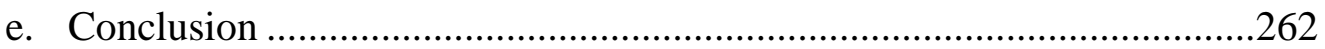

VI. HIDDEN TRENDS: STATE-SPONSORED GROUPS AND NON-STATE

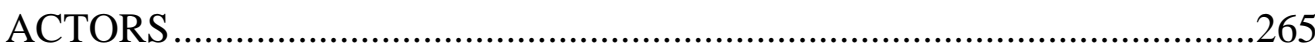

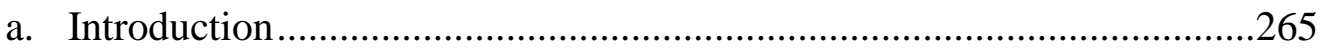

b. A Dynamic Structural Approach to State-Sponsored Groups ..................265

c. Brief Case Studies: State-Sponsored Groups...........................................269

i. Massacres of Armenians in the Ottoman Empire .......................269

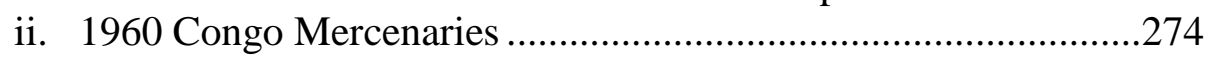

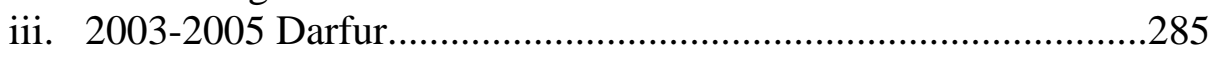

d. A Dynamic Structural Approach to Non-State Actors .............................297

e. Brief Case Studies: Non-State Actors......................................................300

i. 1920s-1940s China.....................................................................300

ii. 1987 Lord's Resistance Army …………………......................308

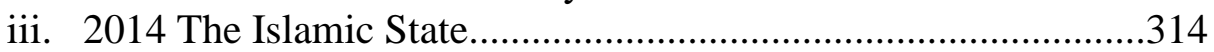




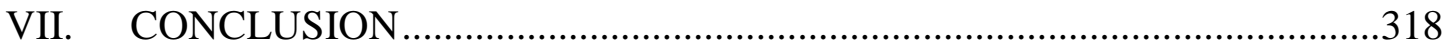

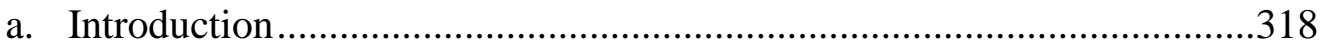

b. Why Rely on a Dynamic Structural Approach to Mass Political

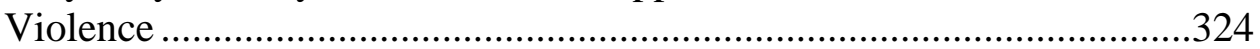

c. Expectations of Mass Political Violence in a $21^{\text {st }}$ Century ........................333

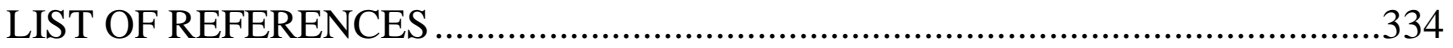

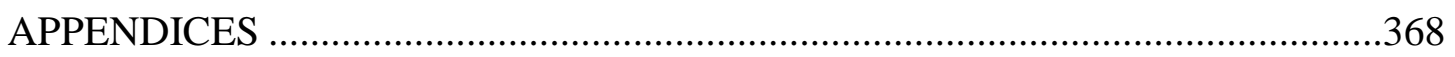

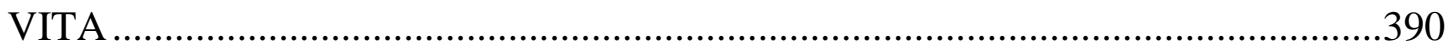




\section{LIST OF TABLES}

TABLE

PAGE

1. Competing and Contested Definitions of Genocide, Listed by Author (Year).......47

2. Sub-Categories of Genocide Classification ..................................................54

3. Substitutive Terms and Categories for Genocide ............................................59

4. A Typological Framework of Mass Political Violence Perpetrators ....................81

5. Perpetrator Ideal Types (Modes) and Defining Characteristics...........................93 


\section{LIST OF FIGURES}

FIGURE

PAGE

1. Major Concepts of Extreme Violence with Overlapping Characteristics ...............5

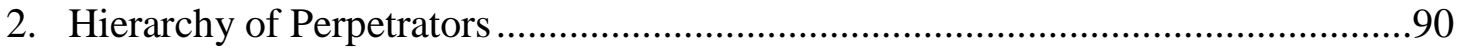

3. A Model of the Generic Process of Mass Political Violence................................117

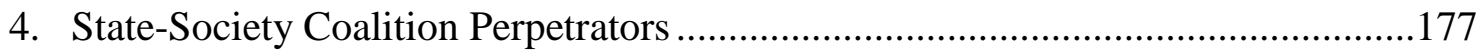

5. Mapping Case Studies of Mass Political Violence by Perpetrator Ideal Type .......323 


\section{CHAPTER I: INTRODUCTION}

\section{Statement of Problem}

In March 2016, the U.S. Secretary of State John Kerry announced that a non-state armed group calling itself the "Islamic State" (IS) committed genocide against religious and ethnic minorities in Iraq and Syria. ${ }^{1}$ This acknowledgement came more than 65 years after the international community ratified a Convention whose aim was to prevent and punish such crimes. ${ }^{2}$ The twentieth century has seen an extraordinarily large degree of mass murder, which culminated in between 60 and 360 million deaths as a result of genocide and mass killing episodes. ${ }^{3}$ This trend of extreme violence, qualitatively, shows little sign of abatement in the $21^{\text {st }}$ century. Perhaps, now more than ever, the central question of this dissertation needs asking: why do different kinds of genocide and mass political violence emerge in different social and political contexts?

Why is there a large range in the number of civilians killed? One reason estimates of civilian casualties vary stems from the plethora of terms describing intentional killing of civilians and non-combatants. Since the 1940s there have been two categories of terms. First, legal terms, which hold tangible consequences for individuals when they are violated; and second, political terms, which were developed by those in academia and policy circles but have not been codified into domestic or international law. Raphael

\footnotetext{
${ }^{1}$ Elise Labott and Tal Kopan. March 18, 2016. "John Kerry: ISIS responsible for genocide," CNN. URL: http://www.cnn.com/2016/03/17/politics/us-iraq-syria-genocide/.

${ }^{2}$ In 1948 the United Nations General Assembly adopted The Convention on the Prevention and Punishment of the Crime of Genocide, codifying into international law this crime. The Convention entered into force in January 1951.

${ }^{3}$ Rudolph Rummel. 1997. Statistics of Democide: Genocide and Mass Murder since 1900. Piscatawy, NJ: Transaction Publishers, Rutgers University, p. 355.
} 
Lemkin initiated this conceptual debate in 1944 by introducing the term "genocide," to characterize a coordinated campaign of mass murder under Hitler's Third Reich. ${ }^{4}$

Lemkin's concept was adopted by the United Nations and incorporated into the Genocide Convention by designating such acts as an international crime. The Convention states that genocide is "[the] intent to destroy, in whole or in part, a national, ethnical, racial or religious group, as such:

a) Killing members of the group;

b) Causing serious bodily or mental harm to members of the group;

c) Deliberately inflicting on the group conditions of life calculated to bring about its physical destruction in whole or in part;

d) Imposing measures intended to prevent births within the group;

e) Forcibly transferring children of the group to another group,"5

Near the conclusion of the $20^{\text {th }}$ century the term "ethnic cleansing" emerged out of the Yugoslav wars of the 1990s to describe genocidal acts that occur within a geographically defined territory. Ethnic cleansing was adopted as a crime against humanity by the United Nations in $1993 .^{6}$

Nearly concurrent to these debates under international law was an explosion of conceptual terms in academia. Barbara Harff and Ted Gurr advanced the term "politicide," which is "the murder of any person or people by a government because of

\footnotetext{
${ }^{4}$ Raphael Lemkin. 1944. Axis Rule in Occupied Europe. Washington, D.C.: Carnegie Endowment for International Peace.

${ }^{5}$ Leo Kuper. 1981. Genocide. New Haven, CT: Yale University Press.

${ }^{6}$ Ruti Teitel. 1996. “Judgment at The Hague.” East European Constitutional Review 5(4) (Fall): 80-85.
} 
their politics or for political purposes. ${ }^{17}$ Harff and Gurr sought to capture episodes of mass violence that were not covered under the Genocide Convention, specifically peoples targeted for their political beliefs. Rudolph Rummel argued his concept of "democide" was most suitable for examining this level of violence. Defined as, "The murder of any person or people by a government, including genocide, politicide, and mass murder." Benjamin Valentino examined major episodes of political violence in the twentieth century and introduced "mass killing" into our lexicon, defined as, "the intentional killing of a massive number of noncombatants."

Valentino's introduction of the term mass killing to our debate revolutionized the way we think of major episodes of political violence (see footnote 11). Christian Gerlach developed "extreme violence" to describe mass violence and murder within society that is characteristically fluid. ${ }^{10}$ Despite the notoriety of these terms and their wide usage, others remains to define similar episodes of violence, including: mass political murder, massacres, pogroms, and political violence to describe types of conflicts civilians confront. Figure 1 maps the highly complex and subjective nature of these terms. The line thickness, color, and shape serve to distinguish their overlapping qualities in a manner that makes them easily seen. The size of the circle indicates each term's analytical ability to classify cases of extreme violence.

\footnotetext{
${ }^{7}$ Rudolph Rummel. 1994. Death by Government. New Brunswick, NJ: Transaction Publishers, p. 31.

${ }^{8}$ Ibid.

${ }^{9}$ Benjamin Valentino. 2004. Final Solutions: Mass Killing and Genocide in the $20^{\text {th }}$ Century. Ithaca, NY: Cornell University Press, 10-15.

${ }^{10}$ Christian Gerlach. 2010. Extremely Violent Societies: Mass Violence in the Twentieth-Century World. Cambridge: Cambridge University Press.
} 
As displayed in Figure 1, many of these dominant concepts in genocide studies (i.e., genocide, democide, mass murder, mass political murder / politicide, mass killing, ethnic cleansing, and the author's term, "mass political violence” overlap a great deal. There are two good reasons to study the overlapping nature of these concepts. First, the reader can visually comprehend the highly complex and overlapping nature of, for example, ethnic cleansing with all other terms except mass murder. Second, scholars have been perpetually confronted by the continual development of such terms and when asked to classify cases by these categories, they are faced with near insurmountable decisions. This dissertation, in part, aims to address this debate by introducing a new concept, "mass political violence," which covers a much broader range of violent cases in human history, thereby lending itself too greater scholarly, academic, political, and policymaking relevance. 
Figure 1.1:

\section{Major Concepts of Extreme Violence with Overlapping Characteristics ${ }^{11}$}

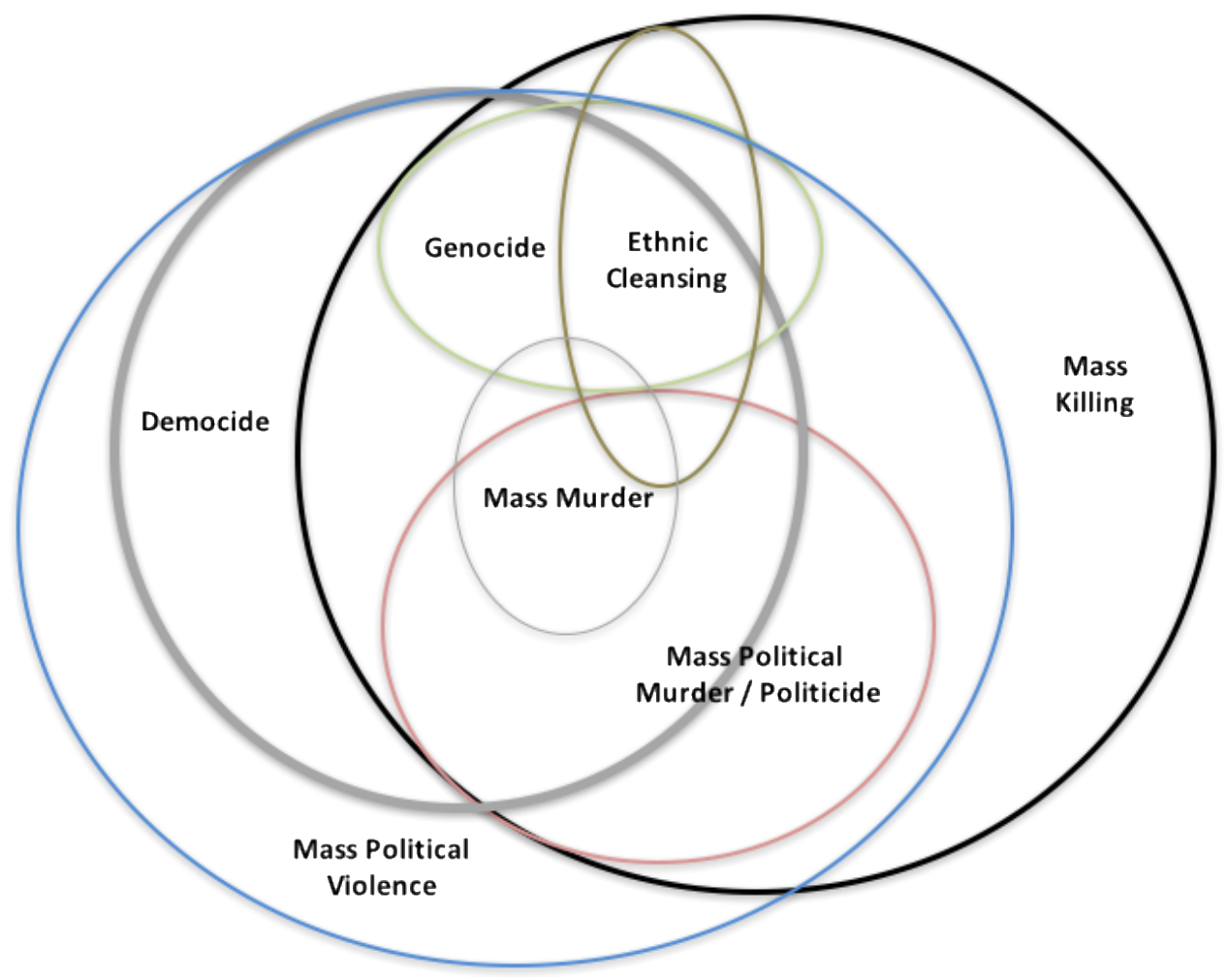

Part of the problem in the sub-field of genocide studies is the seemingly

exponential growth of concepts to define large-scale loss of life. In the perspective of the

author, Benjamin Valentino's characteristics of mass killing capture a large number of

\footnotetext{
${ }^{11}$ Here is a list of concepts with their definitions included in Figure 1. Mass killing is "the intentional killing of a massive number of noncombatants," with three associated characteristics. First, the killing is intentional, second, there must be a minimum of 50,000 victims within a period of five or fewer years, and third the victims must be civilians or noncombatants, see Valentino, 2004, Final Solutions, p. 9-15; Mass political murder is "Politically motivated violence that directly or indirectly kills a substantial proportion of a targeted population, combatants and noncombatants alike, regardless of their age or gender" in Chirot and McCauley, 2006, Why Not Kill Them All?, p. 19; Politicide is "the murder of any person or people by a government because of their politics or for political purposes," Rummel, 1994, Death by Government; Mass murder is "the indiscriminate killing of any person or people by a government," Rummel, 1994, Death by Government; For genocide definition see text above; Ethnic cleansing is "focused on geography and on forced removal of ethnic or related groups from particular areas (related to genocide)" by Benjamin Lieberman; Democide is "the murder of any person or people by a government, including genocide, politicide, and mass murder" Rummel, 1994; Mass political violence is "Mass political violence is the intentional killing, in whole or part, of a discernible group, by a government, its agents, or an organized social unit," with four associated characteristics described in the "Theoretical Framework" section of this dissertation.
} 
these episodes, but with one significant drawback: The threshold requirement of at least fifty thousand victim deaths within a five-year period or less presents a high bar for scholars. It is with this shortcoming in mind that I introduce the concept of study for this dissertation, mass political violence. Rather than introducing a new concept that is narrowly defined, this dissertation introduces and defines mass political violence in such a way as to lend itself for greater comparison of episodes of violence and murder directed against civilian populations. In Part II, I will define mass political violence and its four characteristics for the reader.

This dissertation addresses the issue of generalizability. Since the Holocaust, the sub-field of genocide studies has based our understanding of this phenomenon on the Holocaust as prototypical of all genocides. ${ }^{12}$ The Nazi campaign of extermination against Jews, Roma, homosexuals, political dissenters, handicapped, and other religious minorities has established a benchmark to which all other cases have been compared, either directly or indirectly. This dissertation challenges, however, this implicit assumption within the field that all genocides are directly comparable to one another. It is true that the Holocaust and Rwanda are comparable at a high level of abstraction. However, to gain greater analytical leverage, we must begin to disaggregate episodes of mass political violence into comparable categories that exhibit similar causal mechanisms. In doing this, we can better unpack the problem of why perpetrators of genocide and mass political violence emerge, and how they accomplish these goals. Understanding these two complexities will be the focus of this dissertation.

\footnotetext{
${ }^{12}$ Alexander Laban Hinton, Thomas La Pointe, and Douglas Irvin-Erickson, eds. 2014. Hidden Genocides: Power, Knowledge, Memory. New Brunswick, NJ: Rutgers University Press, 5-9.
} 


\section{Thematic Literature Review}

As an interdisciplinary field, the study of genocide and mass atrocities has substantially grown over the past two decades. This line of inquiry has grown in both size and sophistication since the seminal works of Raphael Lemkin, Hannah Arendt, Irving Louis Horowitz, Helen Fein, Leo Kuper, and Israel Charny between the mid-1940s and early 1980s. ${ }^{13}$ Most scholarship emanated from the study of the Holocaust until the early 1990s, when scholars began to examine more episodes from Africa and Eastern Europe. ${ }^{14}$ In the decades since, there have been six primary analytical research programs: (1) intergroup relations, (2) regime type, (3) hardship and upheaval, (4) ideology, (5) leaders' strategies and (6) modernity and development. ${ }^{15}$ This literature review categorizes the bulk of scholarship in the field along these lines, identifying competing theories of state and society involvement as a crucial issue across the literature. It concludes by discussing existing risk factors that contribute to the onset of genocide and mass political violence, another key problem in the literature.

Research Domain 1: Intergroup relations. Scholars operating within this research paradigm emphasize the role intergroup relations play in fomenting conflict in society.

\footnotetext{
${ }^{13}$ Raphael Lemkin. 1944. Axis Rule in Occupied Europe. Washington, D.C.: Carnegie Endowment for International Peace; Hannah Arendt. 1951. The Origins of Totalitarianism. New York: Harcourt, Brace \& World; Hannah Arendt. 1970. On Violence. New York: Harcourt Brace Jovanovich, Publishers; Irving Louis Horowitz. 1976. Genocide: State Power and Mass Murder. New Brunswick, NJ: Transaction; Helen Fein. 1979. Accounting for Genocide: National Responses and Jewish Victimization during the Holocaust. New York: Free Press; Leo Kuper. 1981. Genocide. New Haven, CT: Yale University Press; Israel Charny. 1982. How Can We Commit the Unthinkable? Genocide, the Human Cancer. Boulder, CO: Westview.

${ }^{14}$ Finkel and Straus. 2012. "Macro, Meso, and Micro Research on Genocide: Gains, Shortcomings, and Future Areas of Inquiry." Genocide Studies and Prevention 7(1) pp. 56-67.

${ }^{15}$ Ibid.
} 
For these individuals, lack of positive intergroup relations bears a central role in the development of conflict and extreme violence. Leo Kuper argued that it is this division between groups that must be present for the evolution of genocide to emerge. ${ }^{16}$ Kuper's analysis of societal divisions helped generate this domain of inquiry. Building upon Kuper's assessment of social cleavages, Helen Fein expanded the analysis beyond intergroup (or lack thereof) relations and introduced the role of power. ${ }^{17}$ Fein contends when the dominant group determines a subordinate group to be "outside the universe of obligation," extreme violence may emerge as a result of this elite determination. In recent years Daniel Chirot and Clark McCauley have stressed two factors in the onset of genocide: group power imbalances and a lack of interdependence and social interactions between groups. Chirot and McCauley claim these two factors enables elites and groups to capitalize on four drivers of violence: convenience, revenge, simple fear, and fear of polluting the quality of one's socio-cultural group. ${ }^{18}$ Similarly, Daniel Goldhagen argues that "widespread eliminationist hatred" is the cause of the Nazi Holocaust. ${ }^{19}$ These scholars often rely on the work of Philip Zimbardo, a psychologist who, among many other things, contributed to political science's understanding of the role dehumanization and deindividuation play in enabling perpetrators to commit heinous crimes. ${ }^{20}$

\footnotetext{
${ }^{16}$ Kuper, 1981, Genocide.

${ }^{17}$ Fein, 1979, Accounting for Genocide.

18 Daniel Chirot and Clark McCauley. 2006. Why Not Kill Them All? The Logic and Prevention of Mass Political Murder. Princeton, NJ: Princeton University Press.

${ }^{19}$ Daniel Goldhagen. 2009. Hitler's Willing Executioners: Ordinary Germans and the Holocaust. New York: Knopf.; Daniel J. Goldhagen, 2009. Worse than War: Genocide, Eliminationism, and the Ongoing Assault on Humanity. New York: Public Affairs.

${ }^{20}$ Philip Zimbardo. 2007. The Lucifer Effect. New York: The Random House.
} 
Research Domain 2: Regime type. Analyzing the role regime type plays in instigating violence has always been a central line of inquiry within political science broadly and this particular sub-field. Rudolph Rummel's seminal works on authoritarianism and totalitarianism's links to democide (genocide and mass murder by the state) catapulted this research program into relevancy. Rummel asserted totalitarian states are more likely to commit mass murder than authoritarian regimes, and both are significantly more likely to engage in this policy than democracies. ${ }^{21}$ Likewise, Irving Horowitz, a sociologist by training, links regime type, in the aggregate sense to enhanced likelihoods of state-directed mass murder. ${ }^{22}$ Both Rummel and Horowitz's work initiated this research domain by making broad, generalizations about the correlations between regime type and extreme violence. In the years since their seminal works, other scholars have provided increased nuance. Barbara Harff asserts regime type matters alongside supporting other supporting factors, including: ethno-cultural minority elites for instance. ${ }^{23}$ However, unlike the former research domain, there is less consensus on the impact of regime type with the onset of extreme violence. Benjamin Valentino, Jay Ulfelder, and Matthew Krain do not find evidence that greater autocracy leads to greater mass murder. ${ }^{24}$

\footnotetext{
${ }^{21}$ Rudolph J. Rummel. 1994. Death by Government. New Brunswick, N.J.: Transactions Publishers; Rudolph Rummel. 1998. Statistics on Democide: Genocide and Mass Murder since 1900. Wissenschaftliche Paperbacks.

${ }^{22}$ Horowitz, 1976, Genocide.

${ }^{23}$ Barbara Harff. 2003. "No Lessons Learned from the Holocaust? Assessing Risks of Genocide and Political Mass Murder since 1955.” American Political Science Review 97(1), pp. 57-73.

${ }^{24}$ Valentino, 2004, Final Solutions; Jay Ulfelder and Benjamin Valentino. 2008. “Assessing Risks of StateSponsored Mass Killing,” Political Instability Task Force, http://papers.ssrn.com/sol3/papers.cfm?
} 
Research Domain 3: Hardship and upheaval. The chief concern for researchers who stress the role of hardship and upheaval in society focus lies in deep-seated structural problems or tipping points that trigger extreme violence. As Freek Colombijn and J. Thomas Lindblad assert the roots of (mass?) violence in Indonesia lie in hardships of specific actors (e.g., youth organizations or economic disenfranchisement) as factors supporting violence after triggering events (i.e., the coup d'état). ${ }^{25}$ David Gibbs argues, counterfactually, absent economic downturns in Yugoslavia and Rwanda the onset of extreme violence in these respective states could have been less severe or minimized during the conflict. ${ }^{26}$ Fundamentally, at the core of this research program, lies the frustration-aggression hypothesis, that is, the idea that these tensions and resentments enable actors to capitalize on structural factors or immediate triggering events that shift society from "normal" levels of violence into extreme violence. ${ }^{27}$ Ervin Staub and Peter Uvin explored this hypothesis in their respective works on political violence. ${ }^{28} \mathrm{Harff}$ makes similar claims that political upheaval can significantly increase the onset of geno/politicide in states. ${ }^{29}$ She contends, that dramatic political shifts can make

\footnotetext{
abstract_id=1703426; Matthew Krain. 1997. "State Sponsored Mass Murder: The Onset and Severity of Genocides and Politicides," Journal of Conflict Resolution 41(3): 331-60.

${ }^{25}$ Freek Colombijn and J. Thomas Lindblad, eds. 2002. Roots of Violence in Indonesia: Contemporary violence in historical perspective. Leiden, The Netherlands: KITLV Press.

${ }^{26}$ David N. Gibbs. 2009. First Do No Harm: Humanitarian Intervention and the Destruction of Yugoslavia. Nashville: Vanderbilt University Press.

${ }^{27}$ Finkel and Straus, 2012, "Macro, Meso, and Micro Research on Genocide."

${ }^{28}$ Ervin Staub. 1989. The Roots of Evil: The Origins of Genocide and Other Group Violence. Cambridge: Cambridge University Press; Peter Uvin. 1998. Aiding Violence: The Development Enterprise in Rwanda. West Hartford: Kumarian.

${ }^{29}$ Harff, 2003, "No Lessons Learned from the Holocaust."
} 
(statistically) significant shifts in the likelihood in onset of extreme violence, particularly, if actors act upon existing social, political, cultural, and economic or otherwise determine cleavages in society.

Research Domain 4: Ideology. Perhaps the most researched field inside political science on genocide is based in unpacking the role ideology plays. Examining ideological frameworks of elites and the masses has clued scholars into deep-rooted belief systems and cued us into understanding motivators of violence. To the layperson, ideology is the sine qua non of genocide studies. Scott Straus asserts ideology played a critical role in the development of Rwanda's 1994 genocide against the Tutsi and moderate Hutus. Straus stresses the role race, as an ideology of "ethnic group categorization," played in grouping an opposing ethny's ${ }^{30}$ civilians with opposing ethny enemy combatants. ${ }^{31}$ This eliminationist ideology based on racial grouping of civilians and elites is arguably one of the main drivers of extreme violence after the end of the Cold War. Similarly, Ben Kiernan contends race, agrarianism, and territorial expansion are key factors in the development of genocide. ${ }^{32}$ Timothy Snyder writes that the Holocaust was conceived, in part, for the Nazi ideological goal of racial purity alongside the establishment of territorial expansion and in that development of "living space" for the ethnic German

\footnotetext{
${ }^{30}$ According to Darnell Felix Hawkins, an ethny, or its plural ethnies, is, “... a group of people who claim common descent and share a common language and culture..." in Hawkins. 1995. Ethnicity, Race, and Crime: Perspectives Across Time and Place. Albany, NY: State University Press of New York, p. 4.

${ }^{31}$ Scott Straus. 2006. The Order of Genocide: Race, Power, and War in Rwanda. Ithaca, NY: Cornell University Press.

${ }^{32}$ Ben Kiernan. 2007. Blood and Soil: A World History of Genocide and Extermination from Sparta to Darfur. New Haven: Yale University Press.
} 
populations. ${ }^{33}$ Those who subscribe to this line of research, tend to argue in top-down or elite-centric modes of violence emanating from perpetrators who espouse an ideological viewpoint with the aim of violence.

Research Domain 5: Leaders'strategy. This dissertation falls squarely within this realm of genocide studies traditions, insofar as we can study the strategies, motivations, and tactics of perpetrators. This research claims that genocide and mass atrocities are implemented by elites (predominantly political and military, but also including ethnic, cultural, and other elites as context deems influential) instrumental in achieving desired goals and objectives. ${ }^{34}$ Benjamin Valentino is perhaps most influential in this sub-subfield. Taylor Seybolt argues mass killing is instrumentally chosen by elites during times of crisis (i.e., at specific "tipping points"). ${ }^{35}$ Manus Midlarsky argues that state imprudence and realpolitik measures coupled with the fear of loss have led to genocide and mass murder in the twentieth century. ${ }^{36}$ Other emerging scholars assert that ethnicity, race and cultural differences are by-products of competition for state supremacy and the maintenance of power in post-colonial settings. ${ }^{37}$ For the most part, these scholars, spearheaded by Valentino, Dylan Balch-Lyndsay, Ulfelder, and Paul Huth, contend

\footnotetext{
${ }^{33}$ Timothy Snyder. 2015. Black Earth: The Holocaust as History and Warning. London: The Bodley Head.

${ }^{34}$ Benjamin Valentino, 2004, Final Solutions.

${ }^{35}$ Seybolt, Taylor B. with Shena L. Cavallo, Stephen Coulthart, Zachary A. Karazsia, Aurora Matthews, and Farhod Yuldashev (2011) "Unpacking the Process of Mass Killing: Motives, Means, and Opportunities," presented by Dr. Taylor B. Seybolt, at the Annual Meeting of the American Political Science Association, Seattle, Washington, September 1-2, 2011.

${ }^{36}$ Manus Midlarsky. 2005. The Killing Trap: Genocide in the Twentieth Century. Cambridge: Cambridge University Press.

${ }^{37}$ Noah R. Bassil. 2013. The Post-Colonial State and Civil War in Sudan: The Origins of Conflict in Darfur. London: I.B. Tauris.
} 
context matters in shaping politico-military elite strategies. Valentino, Balch-Lyndsay and Huth assert that governments are more likely to engage in mass killing during guerrilla wars than other military contexts. ${ }^{38}$ This dissertation will engage with this subscholarship of literature on comparative genocide studies, while accounting for competing risk factors and correlated research programs as discussed herein.

Research Domain 6: Modernity and development. To a lesser extent, scholars have linked the process of modernization and development to the systematic mass murder of civilians and non-combatants. This area of inquiry is less developed and comprehensive than the previous research domains, though Zygmunt Bauman has written on the Holocaust and its correlation to modernity. ${ }^{39}$ Bauman's work tracing the evolution of state formation and its impact on the Holocaust. He asserts "Medieval societies were more like preserves overseen by gamekeepers-do little and the species will reproduce themselves. But modern society is more like one sculpted by a gardener. Each plant must have a reason to be there, or it may be deemed a weed and deserved extermination." 40

The argument Bauman makes is against the traditional notion that Nazism was evil because it was composed of Nazis, and Nazis were evil because they tended to attract evil people. ${ }^{41}$ Bauman contends this traditional, individual level explanation of the

\footnotetext{
38 Benjamin Valentino, Paul Huth, and Dylan Balch-Lyndsay. 2004. "Draining the Sea: Mass Killing, Guerrilla Warfare," International Organization 58(2): 375-407.

${ }^{39}$ Finkel and Straus. 2012. "Macro, Meso, and Micro Research on Genocide Studies", pp. 58.

40 Zygmunt Bauman. 1989. Modernity and The Holocaust. Ithaca: Cornell University Press, p. 57.

${ }^{41}$ Bauman, 1989, p. 157.
} 
Holocaust is inadequate and illogical. He argues we need to examine the process of modernization, that is, the development of bureaucracies, state-capacity, and formation as an integral part of the explanation. If this line of inquiry bear fruit, we should reconsider the role of modernity in the development of mass political violence.

In addition to the sixth research streams of macro-level genocide research, as discussed by Finkel and Straus so eloquently, there are four, non-mutually exclusive theories worth noting in some detail. These paradigmatic viewpoints help shed light on the debate surrounding the process of violence and mass atrocities. Specifically, it is worth mentioning four paradigms: (1) state-centric views of atrocities, (2) genocide as social practice, (3) a revisionary attempt to bring the former and latter together, and not directly related to the above debates but important in its own right is the debate over (4) intentionalist versus functionalist scholarship of genocide and extreme violence. This dissertation grapples with these competing perspectives and ultimately take a position within this conceptual and theoretical debate.

Beginning with Hannah Arendt, who is not exclusively a genocide scholar but a political theorist first and foremost, and continuing with Leo Kuper, Frank Chalk and Kurt Jonassohn, Rudolph Rummel to more recent contributors, the sub-field has been dominated by those who argue genocide and mass atrocities driven from above, in a topdown manner. ${ }^{42}$ These state-centric approaches capture many of the causes, motivations,

\footnotetext{
${ }^{42}$ Frank Chalk and Kurt Jonassohn. 1990. The History and Sociology of Genocide: Analyses and Case Studies. New Haven, CT: Yale University Press. Chalk and Jonassohn provide more than regime centered discussions of this phenomenon, but in part because of the time periods they examine, deal with regimes and elites to a greater extent, as well as intergroup conflict and other motivators.
} 
and connective tissue that enables governmental elites to organize, mobilize and implement one-sided violence directed against civilians.

In recent decades, on the other hand, academics like Christian Gerlach, Yang Su, and Evelina Bonnier et al. have forced the sub-field to reassess the role community level actors play in not only the implementation of violence but in its genesis. ${ }^{43}$ Daniel Feierstein juxtaposes, in varying ways, these approaches by examining the Holocaust and Argentina's military juntas as remaking society through genocide. In many aspects, both conceptually and theoretically, these dialectal positions are difficult to reconcile.

Scholarship along this area is developing, and this dissertation aims to close part of this gap.

Finally, scholars of the Holocaust disagree on the role and importance of Hitler. ${ }^{44}$ Largely speaking, this disagreement among scholars falls into two divergent camps. First, intentionalists, who assert Hitler (and since other central figures of genocide, such as, Mao, Pol Pot, Stalin etc.) are critically important for the development of the Holocaust. The phrase "no Hitler, no genocide" is a brief caricature of this camp's perspective. Intentionalists argue, the mass extermination of Jews, homosexuals, handicapped persons, political opponents, and other religious minorities were a direct result of Hitler's long-term planning and strategic framework. Contrary to this viewpoint, functionalists assert the Holocaust was a "function" of concurrent events during the war. Hitler's role as

\footnotetext{
${ }^{43}$ Evelina Bonnier, Jonas Poulsen, Thorsten Rogall, and Miri Stryjan. May 2015. "Preparing for Genocide: Community Work in Rwanda." Presented at: ASWEDE Conference on Development Economics, SSE, and Columbia Development Colloquium.

${ }^{44}$ Doris L. Bergen. 2009. War \& Genocide: A Concise History of the Holocaust, second edition. New York: Rowman \& Littlefield Publishers, Inc, pp. 30.
} 
national puppet master is not in contention, but it is debatable whether he conceived of these events in a long-term pre-planned fashion a priori to contingent events. I will return to this debate in the concluding section of Part II and extrapolate on my proposed contributions to this discussion. This dissertation, in part, brackets this debate by addressing a more fundamental question, that is, the actual process of mass political violence which can resemble both intentionalist and functionalist perpetrators.

\section{The Structure of this Dissertation}

The remainder of this dissertation consists of six chapters. Chapter 2 traces the evolution of Raphael Lemkin and the creation of the term "genocide." It then explains six common problems and pitfalls to understanding and prosecuting the crime of genocide. Following this section is a comprehensive analysis of most - if not all - terms and categories conceptualized within the field of Genocide Studies during the post-Lemkin era. Each term and category is discussed in relation to three waves of research: a) first wave which saw limited changes in the definition of genocide; b) second wave which saw the creation of sub-categories and caveats; and c) third wave which includes the creation of alternative concepts for genocide. The chapter concludes by defining the dependent variable of this research project - mass political violence.

Chapter 3 addresses the causes and consequences of mass political violence. This chapter begins with a discussion of contemporary approaches to theorizing genocide and mass political violence episodes. Then it provides information on common assumptions and debates in theory building - within this field of study. The bulk of this chapter is dedicated to a discussion of perpetrators, the presentation of my theory of mass political 
violence and its four conceptually and empirically distinct categories of perpetrators, and a note on how we should define "severity" in analyzing and comparing mass political violence episodes.

With this theoretical framework in mind, Chapters 4-6 address the question of why and how mass political violence perpetrators emerge and enact large-scale violence target populations. Chapter 4 examines the dynamic-structural approach to state-led mass political violence in the Soviet Union and Cambodia. Chapter 5 unpacks the dynamicstructural approach to state-society coalitions in the Holocaust and Rwandan mass political violence episodes. Chapter 6 addresses historically hidden trends in mass political violence studies by analyzing both state-sponsored groups and non-state actors. The first part of this chapter analyzing a dynamic-structural approach to state-sponsored groups with case studies in the Ottoman Empire, Congo-Kinshasa, and Darfur. The second half of the chapter applies the same dynamic-structural approach to non-state actor case studies: 1920s-1940s China, the Lord's Resistance Army, and the Islamic State.

The concluding chapter summarizes the major findings and discusses implications for future research into Genocide Studies and Mass Political Violence. The dissertation ends with a discussion of its potential utility and limitations as they pertain to the wider field of study. The aim of this dissertation is to explore a new theoretical lens by which policymakers, academics, and public intellectuals can understand and compare episodes of mass political violence in our modern society. 


\section{CHAPTER II:}

\section{A CRIME BY MANY NAMES: MASS POLITICAL VIOLENCE AND}

\section{GENOCIDE}

"One look is worth a thousand words."

- Frederick R. Barnard, $1921^{45}$

"Since the Mongol invasions of Europe in the Sixteenth Century, there has never been methodical, merciless butchery on such a scale, or approaching such a scale. And this is but the beginning. Famine and pestilence have yet to follow in the bloody ruts of Hitler's tanks. We are in the presence of a crime without a name."

- Winston Churchill, $1941^{46}$

"The failure of the international community to tackle the problem of genocide is reflected by the failure of the academic community to contribute much to our understanding of the problem."

- Michael Freeman, $1991^{47}$

\footnotetext{
${ }^{45}$ Frederick R. Barnard, Printers' Ink Monthly. Vol. 4, December 1921-May 1922, 96.

${ }^{46}$ Winston Churchill, “The Atlantic Charter” Speech, July 29, 1941, The International Churchill Society, Accessed on February 3, 2017. URL: http://www.winstonchurchill.org/resources/speeches/1941-1945-warleader?start $=10$.

${ }^{47}$ Michael Freeman, "The Theory and Prevention of Genocide," Holocaust and Genocide Studies Vol. 6. (1991) 185.
} 


\section{Introduction}

No single word has emerged to capture the totality of human suffering brought about by the hands of governments and societies, who have "systematically" murdered disfavored groups throughout history. The closest we have come, is the term "genocide," although, even this relatively new concept falls short in some regards. The twentieth century has brought us death and destruction of unimaginable proportions. From the killing of the Herero and Nama populations in present day Namibia ${ }^{48}$, to mass deportations and massacres of Slavs and Armenians under the Ottoman Empire during World War I, ${ }^{49}$ to the systematic extermination of European Jews, Roma, homosexuals, and others marginalized groups by Adolf Hitler's Nazi Germany; ${ }^{50}$ or be it the tens of millions of victims killed at the hands of radical communist regimes, the last twelve decades have brought about a diversity of devastation unparalleled in the modern world. ${ }^{51}$ So much so that some have

\footnotetext{
${ }^{48}$ The German conquest of present day Namibia, formerly known as "German Southwest Africa," was the training ground for German use of the concentration camp. The Herero, Nama and Damara indigenous communities faced the brunt of German colonial violence. Ben Kiernan, Blood and Soil: A World History of Genocide and Extermination from Sparta to Darfur (New Haven, CT: Yale University Press, 2007) 380-390; Adam Jones, Genocide: A Comprehensive Introduction, Second Edition (New York: Routledge, Taylor \& Francis Group, 2011) 122-124.
}

${ }^{49}$ Hannibal Travis, Genocide in the Middle East: The Ottoman Empire, Iraq, and Sudan. Durham, (NC: Carolina Academic Press, 2010) 173-235; Richard G. Hovannisan, "Etiology and Sequence of the Armenian Genocide," in George J. Andreopoulos, eds. Genocide: Conceptual and Historical Dimensions (Philadelphia, University of Pennsylvania Press, 1994) 111-140; Frank Chalk and Kurt Jonassohn, The History and Sociology of Genocide: Analyses and Case Studies (New Haven: Yale University Press, Montreal Institute for Genocide Studies, 1990) 249-289; Vahakn N. Dadrian and Taner Akçam, Judgment at Istanbul: The Armenian Genocide Trials (New York: Berghahn Books, 2011).

${ }^{50}$ Nazi propaganda and ideology portrayed Jews as the root of all social-political problems in Germany. This propaganda also extended to Roma (or gypsies), homosexuals, Communists, Jehovah's Witnesses, AfroGermans, Slavic peoples, criminals or any political discontent. Doris L. Bergen, War \& Genocide: A Concise History of the Holocaust, Second Edition (New York: Rowman \& Littlefield Publishers, Inc., 2009); Timothy Snyder, Black Earth: The Holocaust as History and Warning (London: The Bodley Head, 2015).

${ }^{51}$ Benjamin A. Valentino, Final Solutions: Mass Killing and Genocide in the $20^{\text {th }}$ Century (Ithaca: Cornell University Press, 2004); Yang Su, Collective Killings in Rural China during the Cultural Revolution (Cambridge: Cambridge University Press, 2011); Stéphane Courtois, Nicolas Werth, Jean-Louis Panné, 
called this the "century of genocide." ${ }^{52}$ Chapter four provides a more detailed description of the Holocaust and other Nazi genocidal atrocities. It is worth commenting here, that, though Nazi propaganda may have extended to groups other than European Jews this does not mean that these secondary groups were targets of a "systematic" extermination campaign. European Jewry was specifically and systematically targeted by Nazi propaganda and policy for complete destruction, while other groups like the Roma, gays and lesbians, and other religious minorities were targeted in widespread killing, they did not receive the same level of systematic killing as Jewish communities had.

Comparative Genocide Studies is an adolescent field that aims to understand a centuries old crime. Yet, Adam Jones writes, "Genocide studies has never been a more diffuse enterprise. ${ }^{{ }^{53}}$ It is also one of the most attractive fields of research today to up and coming scholars. The most murderous conflicts no longer exist between and among states of the international community, but are being waged within their borders - largely since the end of the Cold War. ${ }^{54}$ Until the early 2000s, most works in our field focused on "unigenocidal" case studies.$^{55}$ In recent years, influential scholarship has emerged to address patterns among and between genocides. However, much remains to be studied here.

Andrezej Paczkowski, Karel Bartošek, and Jean-Louis Margolin, eds., The Black Book of Communism: Crimes, Terror, Repression (Cambridge, MA: Harvard University Press, 1999).

${ }^{52}$ Samuel Totten, William S. Parsons, and Israel W. Charny, eds., Century of Genocide: Critical Essays and Eyewitness Accounts, Second Edition (New York and London: Routledge, 2004).

${ }^{53}$ Adam Jones, "Diffusing Genocide Studies, Defusing Genocides," Genocide Studies and Prevention 6:3 (Winter 2011) 270.

${ }^{54}$ Christian P. Scherrer, "Towards a theory of modern genocide. Comparative genocide research: Definitions, criteria, typologies, cases, key elements, patterns and voids," Journal of Genocide Research 1:1 (1999) 1323.

${ }^{55}$ A. Dirk Moses, "From the Editor: the eagles and the worms: on the future agenda of genocides studies," Journal of Genocide Research 3:3 (2001) 345-346. 
This chapter traces the evolution of Genocide Studies from Raphael Lemkin to present day. Section two recounts professor Lemkin's founding influences on this academic field and the creation of an international legal regime aimed at protecting social groups from genocide. This following section explains the common problems and pitfalls of studying genocide from an academic and legal perspective. Section three describes the evolution of terms and categories deployed after Lemkin and the UN Genocide Convention's first cut. Finally, this chapter concludes by offering a substitutive term "mass political violence" - for understanding genocide in relation to other forms of largescale political violence.

\section{Raphael Lemkin: A New Perspective on an Old Crime}

In 1943, Raphael Lemkin (1901-1959), a Polish-Jewish lawyer, conceived the term "genocide," to describe Nazi atrocities for his book, Axis Rule in Occupied Europe. ${ }^{56}$ Having grown up with stories of "his family's flight from pogroms and wars by and between Slavs and Germans, ${ }^{57}$ and in conducting his own investigations into the plight of Christians murdered by the Ottoman Empire, Lemkin chose a career in law, because he believed such a job would enable him to punish those who make it their priority, as he said, "[to destroy] groups of human beings." ${ }^{58}$ Lemkin completed his law degree in 1926; in the

\footnotetext{
${ }^{56}$ According to A. Dirk Moses, Lemkin coined the term in 1943 for his book; however, his work was not published until the subsequent year because of "contractual negotiations with the publisher." A. Dirk. Moses, "Raphael Lemkin, Culture, and the Concept of Genocide" in Donald Bloxham and A. Dirk Moses, eds. The Oxford Handbook of Genocide Studies (New York: Oxford University Press, 2010) 22.

${ }^{57}$ Travis, Genocide in the Middle East, 27; Donald Bloxham and A. Dirk Moses, eds., The Oxford Handbook of Genocide Studies (New York: Oxford University Press, 2010) xi.

58 "From the guest editors: Raphael Lemkin: the "founder of the United Nation's Genocide Convention" as a historian of mass violence," Journal of Genocide Research 7:4 (2005) 448; Raphael Lemkin, "Totally
} 
following year he joined the faculty at the Free University of Warsaw, teaching criminal law, and in 1928, was appointed the prosecuting attorney for Warsaw. ${ }^{59}$ Here Lemkin remained until 1934, when he was forced out "by the pro-Hitler Polish government."60 Professor Lemkin thereafter argued through his teachings and research at the university, to achieve the goal of prosecuting governments for committing acts of mass violence against their citizens, requires placing some limits on state sovereignty. ${ }^{61}$ To this end, Lemkin eventually persuaded over 58 countries to ratify the Convention on the Prevention and Punishment of the Crime of Genocide (UNGC) after World War II ended. ${ }^{62}$

As is well known, Lemkin chose the words genos (Greek, meaning race, kin, or tribe) and caedere/occidere (Latin for, to kill or fall) as the basis for devising this new term "genocide." ${ }^{63}$ Lemkin's scholarly and activist work led to a profound change within international law and the academy. ${ }^{64}$ It is thanks to Professor Lemkin's foresight and intellectual abilities, that we now have a vocabulary for writing about heinous crimes such

unofficial," manuscript, undated, New York Public Library, Manuscript and Archives Division, The Raphael Lemkin Papers, Box 2: Bio- and Autobiographical Sketches of Lemkin.

59 Daniel Marc Segesser and Myriam Gessler, "Raphael Lemkin and the international debate on the punishment of war crimes (1919-1948)," Journal of Genocide Research 7:4 (2005) 456.

${ }^{60}$ Tanya Elder, "What you see before your eyes: documenting Raphael Lemkin's life by exploring his archival Papers, 1900-1959," Journal of Genocide Research 7:4 (2005) 471.

61 "From the guest editors: Raphael Lemkin: the "founder of the United Nation's Genocide Convention," 448.

${ }^{62}$ Elder, "What do you see before your eyes," 470; Travis, Genocide in the Middle East, 27; Bloxham and Moses, The Oxford Handbook of Genocide Studies, xi.

${ }^{63}$ Christian J. Tams, Lars Berster, and Björn Schiffbauer, Convention on the Prevention and Punishment of the Crime of Genocide: A Commentary (Oxford: Hart Publishing, 2014) 6.

${ }^{64}$ Dominik J. Schaller, "From Lemkin to Clooney: The Development and State of Genocide Studies," Genocide Studies and Prevention 6:3 (Winter 2011) 245. 
as genocide. Lemkin's views of genocide however, was not restricted to a group's complete physical destruction, but also included any coordinated action:

"...aiming at the destruction of essential foundations of the life of national groups, with the aim of annihilating the groups themselves. The objective of such a plan would be disintegration of the political and social institutions of culture, language, national feelings, religion, and the economic existence of national groups and the destruction of the personal security, liberty, health, dignity and even the lives of the individuals belonging to such groups. Genocide is directed against individuals, not in their individual capacity, but as members of the national [sic] group." ${ }^{.65}$

In this respect, Lemkin envisioned a maximalist understanding of genocide, which included attempts at dismantling inter-generational traditions (e.g., language and culture) and personal freedoms (e.g., liberty, health, and dignity). In other words, genocide is the systematic attempt to "liquidate a national population" which emanates from a chosen "political policy to assure conformity and participation by the citizenry." 66 Therefore, genocide is fundamentally linked to the ethnicization of politics by elites and, according to Scherrer, a "wave[s] of ethnic nationalism-from-below."67

Professor Lemkin opposed equating the term genocide solely with incidents where one group attempted or succeeded in exterminating another group. ${ }^{68}$ Genocide, according to Lemkin, is not simply the mass murder or attempted mass murder of a group, in whole or part, but is the attempt to destroy another group's past, present, and future through

\footnotetext{
${ }^{65}$ Raphael Lemkin, Axis Rule in Occupied Europe: Laws of Occupation, Analysis of Government, Proposals for Redress (Washington, DC: Carnegie Endowment for International Peace, Division of International Law, 1944) 79 , emphasis added.

${ }^{66}$ Irving Louis Horowitz, Genocide: State Power and Mass Murder (New Brunswick, NJ: Transaction Books, 1976) 18.

${ }^{67}$ Christian P. Scherrer, "Towards a theory of modern genocide. Comparative genocide research: Definitions, criteria, typologies, cases, key elements, patterns and voids," Journal of Genocide Research 1:1 (1999) 14.

${ }^{68}$ Travis, Genocide in the Middle East, 29.
} 
eliminating their collective life-force, heritage, and very existence from this world. ${ }^{69}$ Lemkin's maximalist understanding of genocide is made apparent by his many efforts to "search for a word that would capture Nazi ghettos, exclusion from economic life, biopolitical laws like the Nuremberg Laws, and occupation efforts," activities that go beyond mass murder. ${ }^{70}$ This "total war" aspect distinguishes genocide from other crimes against humanity, peace, and war in general. Due to its insidious nature, it has been called the "crime of crimes." 71

No more than five years after the publication of Axis Rule, Lemkin witnessed the United Nations adopt the UNGC. ${ }^{72}$ Drafted in the aftermath of the Holocaust, the UNGC was adopted in 1948. The Convention presents "a very broadly worded" set of offenses that does not limit itself to simply mass murder. ${ }^{73}$ Nevertheless, scholars have debated this legal definition for decades, with some arguing it embodies a minimalist description, based on the limited number of protected groups delineated in its text. ${ }^{74}$ The Convention sets

\footnotetext{
${ }^{69} \mathrm{Ibid}, 32$.

${ }^{70}$ Hannibal Travis comments in electronic communication with the author, March 2, 2018.

${ }^{71}$ William Schabas, Genocide in International Law: The Crime of Crimes (Cambridge: Cambridge University Press, 2009); Larry May, Genocide: A Normative Account (New York: Cambridge University Press, 2010) 1.

72 The General Assembly adopted Resolution 260(III) A on December 9, 1948, and after obtaining the requisite twenty ratifications by member states, the Convention entered into force on January 12, 1951. "Audiovisual Library of International Law," retrieved January 30, 2017, http://legal.un.org/avl/ha/cppcg/cppcg.html.
}

${ }^{73}$ Hannibal Travis, "Genocide, Counterinsurgency, and the Self-Defense of UN Member States Before the International Criminal Court," UC Davis Journal of International Law \& Policy Vol. 22, No. 2, (Spring 2016) 156; Travis, Genocide in the Middle East, 32.

${ }^{74}$ Originally, United Nations Resolution 96(I) "The Crime of Genocide" included racial, religious, political and other groups." The political category was later struck from the final draft of the Genocide Convention, which severely undercut the strength of signatories to prevent and punish systematic attempts to murder a population based on their political beliefs. Ultimately, the UNGC bestows protection on four social groups: national, racial, ethnical, and religious populations. See Barbara Harff, Genocide and Human Rights: 
forth a definition of genocide that reflects the era of its conception. It is vital to remember that international laws particularly of wide ranging magnitudes, are products of their sociopolitical environments. In this case, the Convention was an artifact of much debate between democratic and non-democratic states, of which many previously engaged in campaigns of mass slaughter against civilian populations (e.g., Joseph Stalin's political purges and mass deportations of eight national groups from the Caucus region before the Second World War).$^{75}$

The Norwegian representative to the Convention's proceedings, argued that a new international agreement was necessary "since States could not be depended upon to enforce the Nuremberg Principles against their own leaders." in the wake of World War II and presented states with a set of guidelines for determining which actions constitute war crimes. Similarly, Cuba's representative noted that not all countries have adopted the Nuremberg Principles; therefore a new, superseding international convention was vital to protect citizens. ${ }^{77}$ It was the United States that emphasized the need for a convention because, Lippman claims, "the intent to destroy a group" is what distinguishes genocide from ordinary crimes, such as homicide. ${ }^{78}$ The

\footnotetext{
International Legal and Political Issues (Denver, CO: Monograph Series in World Affairs, Graduate School of International Studies, University of Denver, 1984) Vol. 20, Book 3; Barbara Harff and Ted Robert Gurr, "Toward Empirical Theory of Genocides and Politicides: Identification and Measurement of Cases Since 1945, International Studies Quarterly, Vol. 32, No. 3, (1988) 359-371.

${ }^{75}$ Robert Conquest, The Nation Killers: The Soviet Deportation of Nationalities (The Macmillan Company, 1970).

${ }^{76}$ Matthew Lippman, "A road map to the 1948 Convention on the Prevention and Punishment of the Crime Genocide” Journal of Genocide Studies 4:2 (2002) 178.

${ }^{77}$ Ibid, 178.

${ }^{78}$ Ibid, 181.
} 
United States signed the UNGC, despite opposition from the American Bar Association's president Frank Holman who refused to support "any human rights legislation that infringed on the workings on the US Bill of Rights." ${ }^{.79}$ Holman's argument was that, the US constitution is a contract between the government and its citizens; therefore, international human rights law inherently violates this contract. Thankfully, the US government took its first step toward genocide prevention and punishment even though future administrations would not measure up to the spirit of the Convention i.e., the U.S. did not become a party for another 40 years.

Significantly, however, Article 2 of the UNGC bestows protection against this crime to four social groups: ethnic, racial, religious, and national groups, who confront the following:
a. "Killing members of the group;
b. Causing serious bodily or mental harm to members of the group;
c. Deliberately inflicting on the group conditions of life calculated to bring about its physical destruction in whole or in part;
d. Imposing measures intended to prevent births within the group;
e. Forcibly transferring children of the group to another group;" 80

To the layperson, genocide is often exclusively considered to be the killing of individuals who belong to a minority group. For obvious reasons, this action is easiest to observe because of the magnitude of resources required in murdering large groups of people. Killing, however, is only a fraction of the possible activities génocidaires (perpetrators of genocide) have relied on to annihilate social groups. Killing members of a group, is perhaps the most brutal and direct means of inflicting physical destruction upon them.

\footnotetext{
${ }^{79}$ Elder, "What you see before your eyes," 484.

${ }^{80}$ The Convention on the Prevention and Punishment of the Crime of Genocide, Article 2.
} 
Unfortunately, génocidaire strategies have evolved over the centuries to include many indirect methods, such as starvation from man-made famines, deportation or forced relocations, malnutrition, disease, and neglect. ${ }^{81}$

Leo Kuper describes the initial stages of the Armenian genocidal process that exhibit such characteristics. First, the Armenian soldiers serving in the Turkish army were "emasculated," stripped of their ranks and positions. Soon after this purge of the army, the military began disarming Armenian civilians, thereby making resistance futile. In subsequent years, the military initiated mass deportations countrywide. "The deportations were carefully timed, moving from one region to another... Toynbee reports that in areas of strategic significance, because of proximity to the advancing Russians, the military authority, with the help of the local Kurds, carried out an extermination of the civilian population." ${ }^{\prime 2}$ These actions constitute a direct method of killing. After massacres stopped, "The next stage in the genocide, was the journey to the final destination, the dreary, desolate waste of the Syrian desert and the Mesopotamian valley. The convoys of the exiles were little more than death caravans. The long journey on foot inflicted terrible physical sufferings... The deportations were merely a cloak for genocide. ${ }^{" 83}$ As witnessed during the Turkish Armenian genocide, perpetrators can carefully interweave direct methods of human destruction with indirect means in order to inflict serious harm on a population.

\footnotetext{
${ }^{81}$ Benjamin Valentino outlines a range of indirect activities perpetrators have employed to elicit death and destruction of civilians. "Deaths results from these kind of policies, whether perpetrators devise them to kill civilians or simply coerce them, should not be underestimated. Starvation, malnutrition, exposure, exhaustion, and disease were responsible for a large proportion of mass killing deaths in the twentieth century. Fatalities resulting from these factors sometimes rival direct methods of killing, even in cases notorious for their violence and brutality." Valentino, Final Solutions, 11.

${ }^{82}$ Toynbee, cited in Leo Kuper, Genocide (New Haven: Yale University Press, 1981) 109-112.

${ }^{83}$ Ibid, 109-112.
} 
Further muddying traditional conceptions of genocide is Article 2, subpart (b), which includes actions that cause serious "bodily or mental harm to members of a group (emphasis added)." What constitutes mental harm? Can perpetrators face prosecution if they solely cause "mental harm" but no physical harm to a population? Claudia Card argues that the notion of harm in the UNGC should be "best understood in terms of the loss of significant aspects of one's identity." ${ }^{84}$ Card goes on to equate loss of an identity almost exclusively with an individual's physical death. Scholars like Larry May have pushed back against this conservative assessment, arguing physical death is a significant component of loss, but it is not the sole aspect worth studying. ${ }^{85}$ In fact, during the deliberations preceding the UNGC, a Chinese representative to the ad hoc committee responsible for drafting the text of the Convention raised the issue of mental harm. ${ }^{86}$ The Chinese representative referred his Committee members to Japanese actions during the Second World War. Stephen Gorove summarizes this discussion for us as follows:

“... [Where Japan] built a huge opium extraction plant in Mukden, which could process some 400 tons of opium annually, producing fifty tons of heroin - at least fifty times the legitimate world requirements. This quantity, according to medical authorities, would be enough to administer lethal doses to [sic] from 200 to 400 million persons. The representatives of China pointed out that the Japanese had intended to commit and had actually committed genocide by debauching the Chinese population with narcotics. He considered this to be the most sinister and monstrous conspiracy known in history." 87

\footnotetext{
${ }^{84}$ Quoting Larry May, Genocide: A Normative Account, summarizing Claudia Card's argument, 10.

${ }^{85}$ Ibid, 10.

${ }^{86}$ See p. 176 of Stephen Gorove, "The Problem of "Mental Harm" in the Genocide Convention," Washington University Law Quarterly Vol. 1951, Issue 2 (1951) 174-187.

${ }^{87}$ Ibid, 176-177.
} 
Do systematic alterations of a population's mental state through narcotics rise to the level of causing serious "mental harm" under the UNGC? Historically, common law has resisted giving protections to a person's "peace of mind." ${ }^{\text {" }}$ Nonetheless, judicial bodies have awarded redress when a victim suffers "mental anguish," "mental distress," or "mental cruelty," though, no direct references to "mental harm" have been discovered in judicial decisions. ${ }^{89}$ All this is to say, the UNGC definition allows for a multi-layered maximalist, and simultaneously minimalist, definition of genocide. It is maximalist, in the sense that individuals may be prosecuted for crimes committed against members of a group, even though they fall short of the group's physical destruction. And, minimalist in the sense of limiting these protections to only four protected groups (ethnic, racial, religious, and national) while excluding others (e.g., on the basis of political parties, sexual orientation, or gender).

The UNGC's single greatest achievement was the codification of the prohibition of the use of genocide in international law, and the recognition that the international community, at least in spirit if not action, would work to achieve the Convention's dual mandate of prevention and punishment of systematic attempts to exterminate a population, based solely on its communal characteristics. Despite this substantial improvement to international law, there remain significant drawbacks to the UNGC. ${ }^{90}$

\footnotetext{
${ }^{88}$ Ibid, 180.

${ }^{89}$ Ibid, 183.

90 It is worth noting, the UNGC prohibitions fall under two universal categories of international law: obligatiuris erga omnes and jus cogens. The former being obligatiuris which supersede any single state's territorial boundaries and represents "...integrally structured obligations linking states upon which the obligation is incumbent to the international community as a whole and, thus to all other states." The latterjus cogens - are rules that are "absolute, unconditional, exceptionless, and (perhaps) not dependent upon consent," therefore meaning under no circumstances states or their nationals are permitted to commit,
} 


\section{Problems and Pitfalls:}

\section{Barriers to Explaining and Prosecuting the Crime of Genocide}

In the aftermath of large-scale atrocities, it has become common practice for debates to emerge about whether such acts constitute genocide. ${ }^{91}$ In one respect, this repetitive dialogue has only been possible because of Raphael Lemkin and his tireless effort to promote and educate the global public on the crime of genocide. ${ }^{92}$ However, these deliberations have become all too scripted, with perpetrators and bystander governments alike, making denials, and victims, survivors, and activist groups lobbing complaints. As we know, the term genocide has brought about seismic changes in various academic and professional fields, yet it remains a deeply contested concept. ${ }^{93}$ By definition, genocide was supposed to identify a distinct social phenomenon that had not existed in our lexicon before 1943. ${ }^{94}$ This section will show, despite the benefits of naming mass atrocities "genocide," substantial flaws exist in the legal concept and the process of conducting

participate, or facilitate genocide regardless of exigent circumstances. In short, the international community, at the behest of Raphel Lemkin, has codified these behaviors as illegal and immoral in perpetuity with the ratification of the UNGC in 1951. See Jordan J. Paust, M. Cherif Bassiouni, Michael Scharf, Leila Sadat, Jimmy Gurulé, and Bruce Zagaris, Human Rights Module: On Crimes Against Humanity, Genocide, Other Crimes Against Human Rights, and War Crimes: Third Edition (Durham, NC: Carolina Academic Press, 2014) 5; Harry D. Gould, The Legacy of Punishment in International Law (Palgrave Macmillan, 2010) 65; Harry D. Gould, "Categorical obligation in international law" International Theory Vol 3., No. 2, (2011) 255; The Convention on the Prevention and Punishment of the Crime of Genocide, was adopted by the United Nations in December 9, 1948 and entered into force on January 12, 1951.

${ }^{91}$ Paul Boghossian, “The concept of genocide,” Journal of Genocide Research 12:1-2 (2010) 69.

${ }^{92}$ Elder, "What you see before your eyes," 471.

${ }^{93}$ See Paul Boghossian, “The concept of genocide," Journal of Genocide Research 12:1-2 (2010) 69-80 for a discussion of three flaws to the term genocide.

${ }^{94}$ Eric D. Weitz, "Genocide and the rigor of philosophy: a comment on Paul Boghossian," Journal of Genocide Research 12:1-2 (2010) 101-104. 
rigorous scientific enquiry into its etiology. I am not the first author to highlight some of these concerns. What follows is an explanation of four drawbacks to the UN Genocide Convention that have contributed to the disarray of labelling crimes genocide and two dilemmas that have emerged within academic circles. Other shortcomings exist, but I argue those described here are the most pressing concerns that future scholarship must address.

\section{Problem 1: The Contested Meaning of "Intent"}

Under the UNGC, heads of state or government, public officials, or private individuals can be prosecuted if their actions were "committed with intent to destroy, in whole or part, a national, ethnical, racial or religious group (emphasis added)."95 Two questions arise in response to assessing genocidal intent. How did the drafters of the UNGC envision "intent" and how have opposing interpretations of original intent impeded subsequent prosecutions? Hannibal Travis argues that Genocide Studies have been held back by the creation of an unrealistic standard of intent, which "is nearly impossible to satisfy because it requires the total destruction of a race." 96 In fact, the UNGC is quite clear that genocides directed at exterminating a social group from existence in whole or in part are equally heinous crimes, and subject to punishment under the convention. It is here that we see a collision between genocide's legal and political connotations that has resulted in confusion and misinterpretation for decades. In a court of law, prosecutors must prove dolus specialis, a legal assessment that a "perpetrator clearly seeks to produce the act

\footnotetext{
${ }^{95}$ Convention on the Prevention and Punishment of the Crime of Genocide, 1948, Article 2.

${ }^{96}$ Hannibal Travis, "On the Original Understanding of the Crime of Genocide," Genocide Studies and Prevention 7:1 (Spring 2012) 30.
} 
charged. ${ }^{997}$ Katherine Goldsmith argued that the application of dolus specialis, in establishing genocidal intent, has been an "unforced error," and is not reflected in the original text of the UNGC. She aptly notes:

"The use of dolus specialis as the intent required by the Genocide Convention completely goes beyond the original intent of the Convention's drafters, and especially beyond the intent of Raphael Lemkin. Before dolus specialis was held to be the required intent in the Akayesu trial, no legal document or UN paper had associated it with the crime. Although an argument was put forward in the Travaux Préparatoires to allow judges the freedom to interpret, this was because all cases would involve different circumstances and levels of involvement, requiring a case-by-case interpretation. It was not meant to allow a judge's decision to restrict future decisions. $"{ }^{98}$

Individuals fixed on implementing policies of mass destruction are likely to keep their thoughts private and not disclose criminal aspirations. ${ }^{99}$ Therefore, "obtaining actual proof, beyond a reasonable doubt, that the perpetrator's intention was to destroy the group, in whole or in part" is a high bar to reach. ${ }^{100}$ William Schabas argues that it is this notion of special intent to destroy a social group that sets genocide apart from other international offenses, such as crimes against humanity or war crimes. ${ }^{101}$ Nevertheless, applying dolus

\footnotetext{
${ }^{97}$ Katherine Goldsmith, "The Issue of Intent in the Genocide Convention and Its Effect on the Prevention and Punishment of the Crime of Genocide: Toward a Knowledge-Based Approach," Genocide Studies and Prevention 5:3 (Winter 2010) 241.

${ }^{98}$ Goldsmith, "The Issue of Intent in the Genocide Convention and Its Effect on the Prevention and Punishment of the Crime of Genocide," 254.

${ }^{99}$ Akio Kimura, "Genocide and the modern mind: intention and structure," Journal of Genocide Studies 5:3 (2003) 408.

${ }^{100}$ Goldsmith, "The Issue of Intent in the Genocide Convention and Its Effect on the Prevention and Punishment of the Crime of Genocide," 242; Morten Bergsmo, "Intent" in Samuel Totten and Paul R. Bartrop ed., The Genocide Studies Reader (New York: Routledge, 2009) 22.

${ }^{101}$ William Schabas, Introduction to the International Criminal Court, 2nd ed., (New York: Cambridge University Press, 2004) 38.
} 
specialis to the crime of genocide has been one substantial setback in the punishment of perpetrators to date.

The UNGC established a dual mandate for signatories to prevent and punish the crime of genocide. Contested meanings of intent have led to mixed results in the punishment of perpetrators, and this limitation has bled into the prevention mandate as well. The requirement for establishing intent prior to the behaviors associated with genocide, under points a through e of Article 2 has led governments to deny complicity in criminal acts absent written or agreed upon documentation of orders that explicitly call for the extermination of a group. ${ }^{102}$ The question of intent has become a hotly debated issue in international relations where accused perpetrators deny claims on the basis of this requirement, and it has become a common political and legal defense. For instance, Turkey continues to deny that the actions of the Ottoman Empire, taken against Armenians during the early part of the twentieth century were genocidal. ${ }^{103}$ In response to a recent German parliamentary motion, that described the killing of Armenians at the hands of Ottoman Turks in 1915 as genocide, Turkish President Recep Tayyip Erdoğan remarked:

The Armenian issue is a useful blackmail opportunity against Turkey all around the world, and it is even starting to be used as a stick... I am addressing the whole world. You may like it, you may not. Our attitude on the Armenian issue is clear from the beginning. We will never accept the accusations of genocide. ${ }^{104}$

\footnotetext{
102 Kuper, Genocide, 33.

103 John Kifner, “Armenian Genocide of 1915: An Overview,” The New York Times (May 31, 2013).

${ }^{104} \mathrm{Al}$ Jazeera, "Erdogan: Armenia 'genocide' used to blackmail Turkey," (June 4, 2006) URL: http://www.aljazeera.com/news/2016/06/erdogan-armenia-genocide-blackmail-turkey160604151409300.html.
} 
The difficulty in proving intent, in real-time and after the fact, has created a daunting task for the international community and genocide prevention. Therefore, this misreading of intent with dolus specialis, limits the effectiveness of prevention strategies. This de facto, retroactive process of prevention, does little to thwart genocide from erupting, as does the politics of genocide acknowledgment.

\section{Problem 2: Who Counts?}

As addressed in the previous section, the UNGC was a product of its social-political environment. The Holocaust and other Nazi genocidal atrocities formed the basis of Raphael Lemkin and the UN's definition. Regrettably, not all victim populations of Hitler's Third Reich were "eligible" as protected groups under the UNGC. ${ }^{105}$ The convention grants protection to four social groups: national, ethnic, racial and religious populations. Noticeably absent, are groups formed on the basis of political affiliation, sexual orientation, and the physically or mentally impaired, all of whom had members targeted and killed for the betterment of German National Socialism. Limiting protection under the UNGC to four restricted categories of persons, has been a point of critique for decades. ${ }^{106}$ One area where

\footnotetext{
105 Berel Lang, "Response to Paul Boghossian, 'The concept of genocide,' Journal of Genocide Research 12:1-2 (2010) 82.

${ }^{106}$ See Irving Louis Horowitz, Genocide: State Power and Mass Murder (Transaction Publishers, 1976); Leo Kuper, The Pity of It All: Polarisation of Racial and Ethnic Relations (Minneapolis: University of Minnesota Press, 1977); Leo Kuper, Genocide: Its Political Use in the Twentieth Century (New Haven, CT: 1981); Frank Chalk and Kurt Jonassohn, The History and Sociology of Genocide: Analyses and Case Studies (New Haven \& London: Montreal Institute for Genocide Studies and Yale University Press, 1990); Ervin Staub, The Roots of Evil: The Origins of Genocide and Other Group Violence (Cambridge, UK: Cambridge University Press, 1989).
} 
genocide scholars have focused their combined efforts in combating this restriction, is under the "national group" category.

The Genocide Convention is unusually vague in defining the constitution of this group this confusion has led to the development of two distinct legal understandings (c.f. the Akayesu and Jelisic cases). The Akayesu Case of 1998, tried in the International Criminal Tribunal for Rwanda (ICTR), defined a national group “....as a collection of people who are perceived to share a legal bond based on common citizenship, coupled with reciprocity of rights and duties." ${ }^{107}$ Under the ICTR judicial ruling, one could conceivably prosecute episodes of politicide that target individuals holding a common citizenship and belonging to a particular political party, from earlier draft restrictions even though representatives to the Genocide Convention specifically omitted this category. Thus, providing a potential backdoor to the Convention's shortcomings. The second understanding of a "national group" emerged a year later in the Jelisié Case, tried in the ICTR's sister court, the International Criminal Tribunal for the Former Yugoslavia (ICTY). This case defined "a national, ethnical, or racial group from the point of view of those persons who wish to single that group out from the rest of the community." ${ }^{108}$ This legal understanding is perhaps fuzzier in comparison to the former judicial decision, yet allows courts flexibility in hearing a variety of cases that may qualify as genocide under the Convention. Despite the many associated troubles of subjectivism and objectivism in

\footnotetext{
${ }^{107}$ International Criminal Tribunal for Rwanda, The Prosecutor versus Jean-Paul Akayesu, Case No. ICTR96-4-T, (1998): 132.

${ }^{108}$ International Criminal Tribunal for the Former Yugoslavia, The Prosecutor v. Goran Jelisi. Case No. IT95-10-T, (1999): 22.
} 
determining victim populations, this has been one area of advancement in expanding the category of protected persons. ${ }^{109}$

\section{Problem 3: Thresholds and Scales of Violence}

Is killing one person of a group an act of genocide? How do we practically interpret the UNGC's "in whole or in part" characterization of violence? What does "in part" empirically resemble? Establishing a uniform definition of genocide has been impossible, in part, due to this phraseology. Eric Weitz argues, it is unsustainable to define the killing of one person of a group genocide. ${ }^{110}$ As addressed earlier, the Chinese representative to the drafting committee of the UNGC argued for the inclusion of "mental harm" under prosecutable crimes. Taken literally, no killing is necessary for the punishment of an individual under the UNGC, if that person has contributed to creating severe mental harm to members of a group. ${ }^{111}$ An even more pressing question given increased levels of political violence globally, is, when does a massacre of a group cross into the realm of genocide? What factors conceptually, analytically, and empirically distinguish a massacre of members of a group from a partial or small-scale genocide? There is no easy answer to this question, as is author has discovered. ${ }^{112}$ Jacques Sémelin, a foremost expert on the

\footnotetext{
${ }^{109}$ For a cogent discussion of subjectivisms and objectivism see Christopher Powell, "What do genocides kill? A relational conception of genocide," Journal of Genocide Research 9:4 (2007) 527-547.

${ }^{110}$ Eric D. Weitz, "Genocide and the rigor of philosophy: a comment on Paul Boghossian," Journal of Genocide Research 12:1-2 (2010) 102.

111 The Convention on the Prevention and Punishment of the Crime of Genocide, 1948, Article 2(b).

${ }^{112}$ For the students of massacre, as a conceptually and analytically distinct phenomenon has received scant attention from the discipline. See Jacques Sémelin, "In consideration of massacres," Journal of Genocide Research 3:3 (2001) 377-389.
} 
conceptualization of massacres, argues that there are two archetypal massacres: they are either "carried out in order to impose political domination (the case of submission) or they are aimed at eliminating the group in and of itself (the case of eradication)." ${ }^{113}$ Both of which could qualify as factors within a genocidal campaign. Mark Levene defines massacres as the asymmetry of power relations between groups:

A massacre is when a group of animals or people lacking in self-defence, at least at that given moment, are killed, usually by another group [Coster's point is a valid though not easily resolvable one] who have the physical means, the power, with which to undertake the killing without physical danger to themselves. ${ }^{114}$

Both Semelin and Levene's distinctions and proposed definitions touch upon aspects of genocide, at least in part if not whole. Disentangling small-scale, non-genocidal acts from small-scale genocides has been a particularly thorny problem for legal and genocide scholars.

\section{Problem 4: Politicization of the "G-Word"}

“Is 'genocide' still a powerful word?" Luke Glanville argues that "genocide" has lost some of its "ideational power." 115 In 1994, during the height of the Rwandan genocide, the Clinton Administration, mostly prominently Christine Shelley, spokeswoman for the State Department, declared that only "acts of genocide have occurred" and not

\footnotetext{
113 Jacques Sémelin, “In consideration of massacres,” Journal of Genocide Research 3:3 (2001) 381.

${ }^{114}$ Ibid, 379.

${ }^{115}$ Luke Glanville, “Is “genocide” still a powerful word?” Journal of Genocide Studies 11:4 (2009) 467.
} 
"genocide." 116 The Clinton Administration viewed their use of the "G-Word" as so powerful that its very utterance would constitute a recognition of responsibility under the UNGC, and force the administration to take some actionable steps to stop the spread of genocide in Rwanda. Fast forward nearly a decade, and the Bush Administration felt wholly comfortable describing the atrocities in Darfur as genocide, yet this declarative statement "did not activate legal obligations" on behalf of the U.S., argues Glanville. ${ }^{117}$ To the casual observer, the obvious question remains, so what? Is not the increasing use of the "G-Word" a reflection of positive movements in human rights?

Two vital points bear mentioning here. First, until the $21^{\text {st }}$ century's first genocide (i.e., Darfur), states and their constitutionally responsible leaders made every effort to avoid using the "G-Word" in describing countless episodes of mass violence. ${ }^{118}$ For decades, world leaders feared the politicization of this term and its possible legal obligations. Subsequently, they steered clear of identifying conflicts as genocidal, or at least until the proverbial dust settled. Major Brent Beardsley, an infantry officer in the Canadian Army attached to the U.N. Assistance Mission for Rwanda (UNAMIR), served as a personal staff officer to then Force Commander Major-General Roméo Dallaire. Beardsley subsequently wrote:

"One of the major reasons the genocide in Rwanda was not prevented or stopped was the endless debate in April, May, and June 1994, when the majority of attention and effort was focused on debating whether or not

\footnotetext{
${ }^{116}$ U.S. Department of State, Daily Press Briefing Transcript, Friday, June 10, 1994. Accessed on April 13, 2017 from URL: $\underline{\text { http://dosfan.lib.uic.edu/ERC/briefing/daily briefings/1994/9406/940610db.html. }}$

${ }^{117}$ Luke Glanville, “Is “genocide” still a powerful word?” Journal of Genocide Studies 11:4 (2009) 469.

118 The question of genocide recognition for the victims of the Armenian genocide at the hands of Ottoman Turks, remains a politically vitriolic issue for Turkey and countries seeking a prosperous relationship with this Middle Eastern nation.
} 
genocide was taking place in Rwanda instead on preparing and conducting a multi-disciplinary (including military) intervention to stop the killing." 119

Second, after the turn of the century, we have witnessed a shift in political and social recognition of genocide. After the U.S. condemned the actions of Omar Al-Bashir's government and his associated militia, the janjaweed, in Darfur, Sudan, to be tantamount to genocide, there has been a sea change in the number of conflicts labelled "genocide." In a post-Darfur world, views on the use of the "G-Word" have shifted, from fear of obligations, to that of excessive recognition - even in cases where it may not be warranted. Martin Mennecke writes, "The real problem of genocide prevention is to identify the circumstances under which such situations escalate into genocide - and distinguishing these from situations in which they do not and any external intervention could be deemed an unjustified interference in internal affairs." 120 The over- and misuse of the term genocide, including in official U.S. government documents, like the Genocide Prevention Task Force have further clouded the popular, legal and political understanding of genocide, reasons William Schabas. ${ }^{121}$

\footnotetext{
${ }^{119}$ Major Brent Beardsley, "The Endless Debate over the 'G Word,' Genocide Studies and Prevention 1:1 (July 2006) 79.

${ }^{120}$ Martin Mennecke, "What's in a Name? Reflections on Using, Not Using, and Overusing the "G Word," Genocide Studies and Prevention 2:1 (Spring 2007) 59.

${ }^{121}$ William Schabas, “.... reader who skips the preface to the recent report titled Preventing Genocide: A Blueprint for U.S. Policymakers (the Albright- Cohen Report), the work of the Genocide Prevention Task Force, will miss something important, indeed primordial. Tucked away toward the end of the front matter, under the general heading "Defining the Challenge," is a three-paragraph section titled "Avoiding Definitional Traps." It refers to the definitional challenge of invoking the word genocide, which has unmatched rhetorical power. The dilemma is how to harness the power of the word to motivate and mobilize while not allowing debates about its definition or application to constrain or distract policymakers from addressing the core problems it describes [...] So, in fact, what the Albright-Cohen Report is talking about is "crimes against humanity," not "genocide." Why not simply title the report Preventing Crimes Against Humanity? The explanation is the "unmatched rhetorical power" of the "G-word." William A. Schabas, "Definitional Traps and Misleading Titles," Genocide Studies and Prevention 4:2 (Summer 2009) 177-183.
} 
Within the span of a decade, the pendulum swung from that of ardent resistance, to genocide recognition, to that of exaggerated tagging. This switch in genocide recognition, reflects an effort by some, either intentionally or possibly unintentionally, to undercut the power of the "G-Word" and the phrase "Never Again," so that its loss in ideational, rhetorical, and legal power reduces individual state's international humanitarian obligations. The term is now widely used by dictators to vilify their political enemies.

\section{Problems 5-6: Inside Baseball: Dilemmas in Adhering To Rigorous, Scientific Standards} in Genocide Research

Any serious genocide scholar would categorically reject mainstream, conventional political science debates over empirical versus normative research. Genocide scholars enter this field to make an analytical, political, practical, conceptual, or emotional impact on society through understanding why and how persons can murder, en masse, large groups of people based solely on their social characteristics. "Anyone studying genocide cannot help but feel intense anger and hatred toward genocide and its perpetrators," argues Uğur Ümit Üngör. ${ }^{122}$ The normative objective is crystal clear: a world free of mass human destruction. However, the route to achieving this collective goal must proceed through sound, defensible (qualitative or quantitative), empirically supported scientific inquiry. In the view of this author, it is not only prudent to admit our normative bias here, but entirely necessary in exposing potential scientific prejudices that may emerge from this ideational goal. Unlike some other academic fields, genocide studies has always engendered both an

\footnotetext{
${ }^{122}$ Uğur Ümit Üngör, "Studying Mass Violence: Pitfalls, Problems, and Promises," Genocide Studies and Prevention 7:1 (Spring 2012) 70.
} 
activist and intellectual component, something Adam Jones refers to as a "praxis-oriented component" which can be traced all the way back to the field's founder Raphael Lemkin. ${ }^{123}$ This scholar-activist dynamic has been both an asset in driving the creation of international human rights regimes and a potential liability, in terms of our ability to conduct rigorous, scientific investigations into the causes and consequences of genocide.

A second problem that arises pertains to the relatively new field of comparative genocide studies. Most scholarly research on genocide has historically occurred at the meso-level, meaning, it has remained trapped "in the level of non-comparative research, single case studies." 124 This problem results from two dilemmas. First, some argue the uniqueness of the Holocaust - which has become the de facto prototype by which all genocides are explicitly or implicitly compared - prohibits comparison with other episodes. ${ }^{125}$ Some, have even argued, the Holocaust is a "uniquely unique" event, further separating Holocaust Studies from its kin field of Genocide Studies. ${ }^{126}$ Second, the problem

\footnotetext{
${ }^{123}$ Adam Jones, "Diffusing Genocide Studies, Defusing Genocides," Genocide Studies and Prevention 6:3 (Winter 2011) 274; Tanya Elder, "What you see before your eyes: documenting Raphael Lemkin's life by exploring his archival Papers, 1900-1959," Journal of Genocide Research 7:4 (2005) 469-499; "From the guest editors: Raphael Lemkin: the "founder of the United Nation's Genocide Convention" as a historian of mass violence," Journal of Genocide Research 7:4 (2005) 447-452; Dominik J. Schaller, "From Lemkin to Clooney: The Development and State of Genocide Studies," Genocide Studies and Prevention 6:3 (Winter 2011) 245-256.

124 "From the Editor: the eagles and the worms: on the future agenda of genocides studies," Journal of Genocide Research 3:3 (2001) 345.

${ }^{125}$ For a general discussion see Alan Rosenberg, "Was the Holocaust Unique? A Peculiar Question?" Isidor Wallimann \& Michael N. Dobkowski, Genocide in the Modern Age: Etiology and Case Studies of Mass Death (New York: Greenwood Press, 1987) 145-161.

${ }^{126}$ A term coined by A. L. Eckhardt and A. R. Eckhardt, "The Holocaust and the Enigma of Uniqueness. A Philosophical Effort at Practical Clarification," in I. G. Shur, F. H. Littell and E. Wolfgang, eds, Reflections on the Holocaust: Historical, Philosophical, and Educational Dimensions, Vol 450 of The Annals of the American Academy of Political and Social Science, July 1980, pp 165-178.
} 
of comparative research is further hindered by a lack of definitional consensus on what constitutes "genocide." 127 If every horrifyingly murderous episode is labelled "genocide," then the term has lost all significance. Prior to undertaking comparative studies, scholars must determine the universe of cases are appropriately called that "genocides." For this to happen, we must come to a consensus on the simple question: what is genocide? As will be discussed, dissatisfaction with the definition of genocide and the excessive "caveating" of scholars has led to a plethora of substitute terms in recent years. Definitional traps and a lack of academic and policy consensus continue to plague the field today.

In lieu of an agreed upon definition, genocide scholars have regularly relied upon the 1948 UN Genocide Convention as the preeminent benchmark by which all "analysis of genocide-related case studies and comparisons" are assessed. ${ }^{128}$ Misgivings about this least common denominator of a definition have accrued over time. As a direct result, and in part, due to the problems and pitfalls described above, we have seen the emergence of three waves of genocide scholarship materialize. The next section unpacks the many names given to identify the intentional destruction of a group of people based solely on their communal characteristics.

\footnotetext{
127 "From the Editor: the eagles and the worms: on the future agenda of genocides studies," Journal of Genocide Research 3:3 (2001) 345; Vahakn N. Dadrian, "Patterns of twentieth century genocides: the Armenian, Jewish and Rwandan cases" Journal of Genocide Research 6:4 (2004) 487-522.

${ }^{128}$ Stuart Stein, "Geno- and other cides: a cautionary note on knowledge accumulation," Journal of Genocide Research 4:1 (2002) 39.
} 


\section{The Post-Lemkin Era: Terms and Categories}

In a radio speech to the British Commonwealth on August 24, 1941, in stressing the special alliance between Great Britain and the United States, Winston Churchill referred to Nazi atrocities as profoundly revolutionary, and infamously called them "a crime without a name." ${ }^{129}$ No more than two years after Churchill's proclamation, Raphael Lemkin would coin the first of many terms to describe such barbarism. In the eight decades since professor Lemkin's seminal book, Axis Rule in Occupied Europe, we have seen conceptual proliferation, matched, perhaps, only by the arms race between the cold war adversaries. Dozens of university professors have earned tenure on the basis of coining their own concepts to brand one-sided violence. This conceptual debate erupted from widespread dissatisfaction with the UN definition. Nevertheless, the UNGC has been the standard against which all other terms have been judged. ${ }^{130}$

By my count, since professor Lemkin's seminal work and the ratification of the UNGC, there have been dozens of alternative definitions of genocide offered, at least 24 sub-categories, and at minimum 39 substitute terms for genocide that have been coined by academics, policymakers, independent researchers, journalists, and think tanks over the years (see Tables 2.1, 2.2, and 2.3 for a comprehensive list). I applaud the efforts to further our understanding of such destructive human behaviors by these aforementioned scholars. If our primary concern rests with understanding the common causes of social conflict across time, space, geography, culture, history, language, religion, politics, and

129 The International Churchill Society. Speech titled, "The Atlantic Charter." URL: http://www.winstonchurchill.org/resources/speeches/1941-1945-war-leader?start=10.

\footnotetext{
130 Scott Straus, "Contested meanings and conflicting imperatives: A conceptual analysis of genocide,"
} Journal of Genocide Research 3:3 (2001) 349-375, see p. 361. 
development, then the conceptualization and rules of social scientific investigation matter. Without a common basis for understanding genocide, academics and policymakers cannot begin to develop rigorous theories of one-sided violence or make concrete claims about contemporary episodes. Conceptualization determines which cases are included and which are excluded. This factor may potentially bias scholarly attempts at theorizing. ${ }^{131}$ Theories that explain the Holocaust or Rwandan genocides will be dramatically different from those explaining atrocities by the Islamic State or Boko Haram.

In tracing the evolution of "genocide," scholars have been slow to deviate from existing norms of identification and classification. This incremental expansion of what constitutes genocide, is a positive reflection of our field's professionalism, to not make dramatic divergences from our existing knowledge base of mass violence. In contemporary Western societies, the Holocaust is portrayed as the epitome of evil, especially in North America, although the terms "ethnocide" and genocide" preceded the "Holocaust" in their introduction to our lexicon. ${ }^{132}$ Over time, the latter has come to signify our most heinous of crimes. One implication of this shift in terminology has been, "If mass violence does not resemble the Holocaust in being a massive racial hate crime, it is screened out as nongenocidal." ${ }^{133}$ Practically speaking, genocides that do not reflect Nazi methods of mass murder have all too often faced additional scrutiny for inclusion within this criminal category.

\footnotetext{
${ }^{131}$ Scott Straus, "Contested meanings and conflicting imperatives: a conceptual analysis of genocide," 359.

132 A Dirk Moses, "Revisiting a Founding Assumption of Genocide Studies," Genocide Studies and Prevention 6:3 (Winter 2011) 288.

${ }^{133}$ Ibid, 290.
} 
Beginning with Raphael Lemkin and the UNGC, we have seen three distinct waves of definitional expansion since 1948. Each wave is not a discrete temporal period and many continue today. I use the term "wave" as a heuristic device in grouping similar concepts. In order to compare the more than 80 definitions and terms below, I categorized them based on four criteria. These categories are not mutually exclusive, and many terms exhibit qualities of several. For the ease and utility of comparison, each definition and term has been listed under the category which reflects its primary foci. The initial two categories focus on membership as referent: that being the "victims" or "perpetrators." The latter two, are derived from magnitude of violence: from "small-scale" to "large-scale." Each definition and term is listed below one of these categories, yet as mentioned, many exhibit qualities of more than one. A complete list of alternative definitions of genocide, subcategories of genocide, and substitute terms for genocide can be found in Appendices A-C (at the end of this dissertation).

\section{First Wave: Changes Around the Edge: Alternative Definitions of "Genocide"}

In the post-UNGC era, initial scholarship focused on redefining the meaning of genocide, both for academic analysis and internal validity. This was no coincidence. There are institutional, political, and legal costs to changing the term "genocide." ${ }^{134}$ Scholarship in this wave operated within the confines of re-classifying characteristics of genocide. Pieter Drost was the first to offer a rebuttal definition. ${ }^{135}$ Drost argued that genocide, is

\footnotetext{
${ }^{134}$ Paul Boghossian, “Response to my critics,” Journal of Genocide Research 12:1-2 (2010) 105-112.

${ }^{135}$ Pieter Drost, The Crime of State: Penal Protection for Fundamental Freedoms of Persons and Peoples (A.W. Sythoff, 1959).
} 
"the deliberate destruction of physical life of individual human beings by reason of their membership of any human collectivity as such." ${ }^{\prime 136}$ With this simple re-definition, Drost fired the first shot in this now perennial debate. Noticeably absent from his definition, was the delineation of victim groups. This removal of specificity in defining the victim populations was directly at odds with the UNGC. For Drost, and many scholars to come, membership in any group being targeted for destruction or physical harm would suffice. Drost also differs from Lemkin and the UNGC over the core objective of such actions. ${ }^{137}$ Should we only use the term genocide to reflect violence intended on the group's complete annihilation? Here, Drost contends, the intentional annihilation of a group is not central to the definition of genocide, but merely one possible objective of perpetrators. Conflicts that result in mass physical harm to members of a designated group that do not originate from their complete destruction, should also be counted within this category of offenses, according to Drost. On this point, Leo Kuper and Israel Charny also agree, in their formulations of genocide, that the intentional destruction of an entire group is not central to their conceptualization, instead, they focus on the "mode of annihilation," that being, via the mass killing of a "collectivity" or a "defenseless" population in lieu of perpetrator intention. ${ }^{138}$

\footnotetext{
${ }^{136}$ Scott Straus, "Contested meanings and conflicting imperatives: a conceptual analysis of genocide," 350.

${ }^{137}$ Ibid, 350.

${ }^{138}$ Ibid, 350; Leo Kuper, Genocide: Its Political Use in the Twentieth Century (New Haven, CT: 1981); Israel Charny, The Widening Circle of Genocide (Piscataway, NJ: Transaction Publishers, 1994).
} 
Table 2.1

Competing and Contested Definitions of Genocide, Listed by Author (Year)*

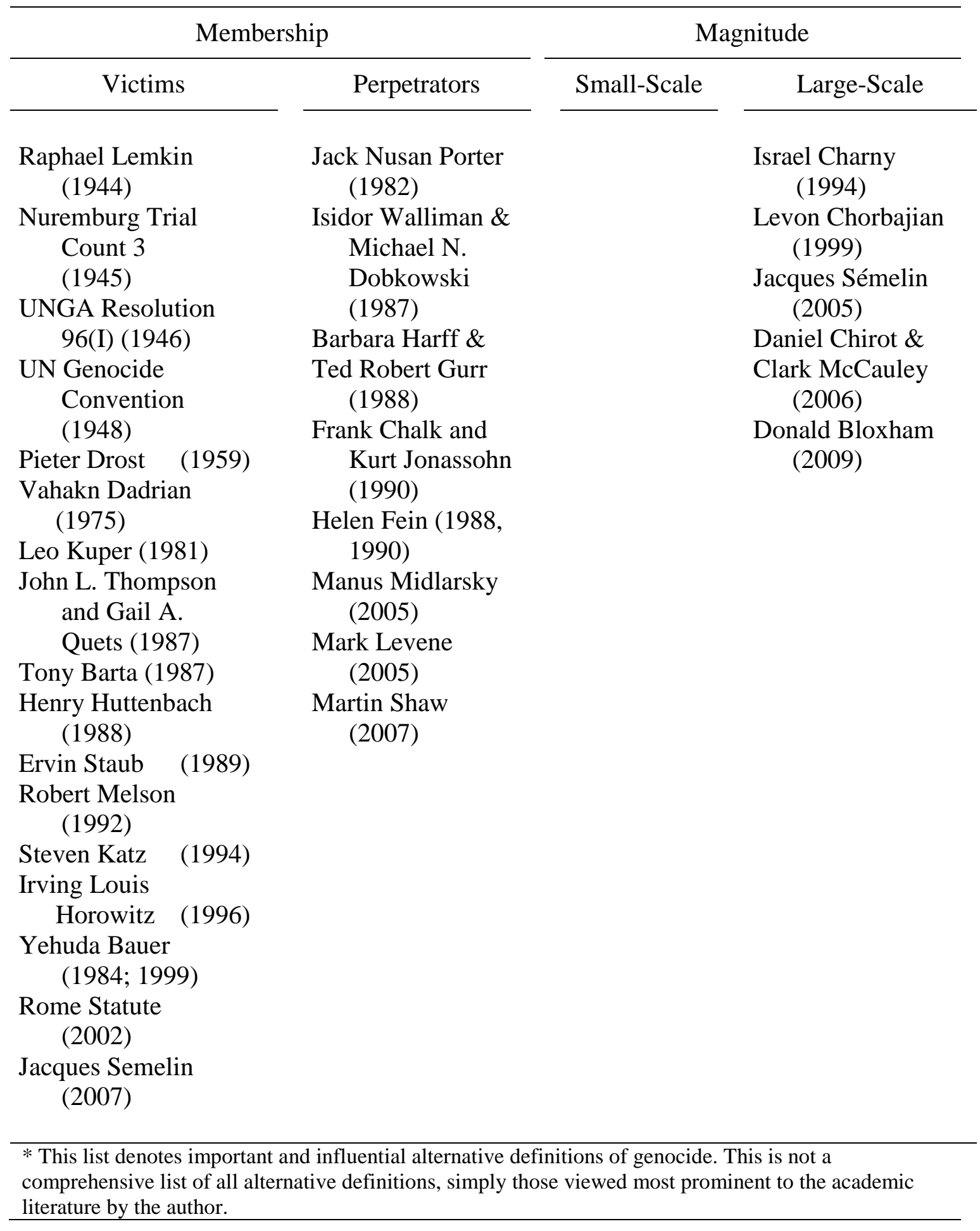


Following Drost's expansion, Vahakn Dadrian offered a more nuanced understanding by stressing the hierarchy of groups embedded in society who are backed by the legal authority of the state, and possess an ideology of extermination; thereby choosing to enact violence against a vulnerable population for the purpose of achieving intergroup supremacy. ${ }^{139}$ Dadrian's definition embodies much of the UNGC's spirit, but he also offers an explanation of the process of genocide in his underscoring of group dynamics and competition over scarce resources. For Dadrian, the state is a conduit for the dominant group to legally execute violence against an oppositional population that cannot sufficiently defend itself. Here, Dadrian introduces both systemic factors, such as group dynamics and power imbalances, accentuated by the dynamism of political opportunity in defining genocide. Dadrian is the first scholar who integrates structural and dynamic factors into his categorization of mass violence. Irving Louis Horowitz expands upon Dadrian's incipient definitional analysis, by emphasizing, "bureaucratic apparatus" of the state that engages in systematic "liquidation of a national population." ${ }^{140}$ For Horowitz, the bureaucratic modernization of the $20^{\text {th }}$ century is essential to defining mass violence as genocide, against (usually) a vulnerable minority group unable to adequately defend themselves from the power of the administrative state. Here Dadrian and Horowitz further refine the UNGC's attention to state institutions as prime perpetrators.

\footnotetext{
${ }^{139}$ Dadrian defines genocide as, “...the successful attempt by a dominant group, vested with formal authority and/or preponderant access to the overall resources of power, to reduce by coercion or lethal violence the number of a minority group whose ultimate extermination is held desirable and useful and whose respective vulnerability is a major factor contributing to the decision for genocide." See Vahakn N. Dadrian, "A Typology of Genocide” International Review of Modern Sociology 5:2 (Autumn 1975): 204.

${ }^{140}$ Irving Louis Horowitz, Genocide: State Power and Mass Murder (Transaction Publishers, 1976).
} 
As shown in Table 1, of preeminent scholarship that sought to redefine the meaning of genocide, no prominent authors did so with the intent of specifying violence on a smallscale. All scholarly alternatives to genocide emphasize the role of the persecution of victim populations (i.e., specifying who counts and who is excluded), stress the importance of perpetrators (i.e., focusing on the role of organizational bureaucracy or systematic, statesponsored methods of mass destruction), or have explicitly shaped their conceptualization of genocide in broad terms to reflect and incorporate large-scale loss of life. The issue of small-scale or "partial" genocides was raised in the preceding section - particularly, the difficulties in analytically distinguishing massacres from partial genocides. The field, as a result, initially sidelined this dilemma and scholars focused their efforts on understanding genocide's many complexities through referencing victim groups, perpetrator methods, or its sheer magnitude of violence. As will be apparent, second and third wave genocide scholarship has attempted to bridge this gap - at least somewhat more than first wave authors.

\section{Second Wave: Qualifications and Caveats: Sub-Categories of Genocide}

The second research program to emerge involved the classification of different kinds of genocide. To date, by my tally, there are at least 24 different kinds of genocides described in the extant literature (see Table 2.2 for a complete list). Early scholars like Leo Kuper, Israel Charny, Frank Chalk, Kurt Jonassohn, Helen Fein, Barbara Harff, Ted Robert Gurr, Roger Smith, Donald Beachler, Yehuda Bauer, and Vahakn Dadrian put forward typologies of genocides. Thereby marking our field's first attempts at disaggregating 
genocide into analytically distinct sub-categories. ${ }^{141}$ Most of the sub-categories listed in Table 2 are derived from these premier authors. Each of the aforementioned scholars' work divides genocide into comparable sub-categories. In the interest of simplicity, I divide these 24 terms into six major groupings of motivations/type; therefore, these genocidal groupings aim: (1) to implement an ideology; (2) to enact revenge or revolution; (3) to scapegoat or repress a rival social group; (4) to colonize or develop a territory; (5) to pursue a struggle for power, and (6) finally, there is an "other" category that includes stand-alone subcategories or a combination of mixed motivations that do not fit neatly into the preceding five domains.

The central motivation of "ideological genocides" resides in the implementation of a belief system that does not include the targeted or marginalized population. Ideology has long been a focus of genocide scholars in theorizing this process and is regularly included as a primary motivator of violence. Roger Smith is among the first to include ideology as one of five sub-categories in his 1987 work "Human destructiveness and politics: the twentieth century as an age of genocide," where he divides genocidal cases into retributive, institutional, utilitarian, monopolistic, and ideological sub-types. ${ }^{142}$ Frank Chalk and Kurt Jonassohn include ideology as one of four sub-categories in their widely referenced book The History and Sociology of Genocide, where they disaggregate genocide by perpetrator objectives, of which ideology is a central driver. Barbara Harff and Ted Robert Gurr detail

\footnotetext{
${ }^{141}$ Other authors have used the label "sub-types" to describe such concepts. For the purpose of this research, sub-categories and sub-types can be used interchangeably.

${ }^{142}$ See Roger Smith, "Human destructiveness and politics: the twentieth century as an age of genocide," in Isidor Walliman and Michael Dobkowski, eds, Genocide and the Modern Age: Etiology and Case Studies of Mass Death (Westport: Greenwood Press, 1987), 23-27.
} 
genocides fueled by xenophobic beliefs, as in the killing of Ache Indians in Paraguay from 1962-72, the Ibos living in northern Nigeria from May to October 1966, and Muslims residing in Burma's border region in $1978 .{ }^{143}$ Finally, and perhaps most well-known is Helen Fein's four-part classification of ideological, retributive, developmental and despotic genocides. ${ }^{144}$ As mentioned, most of the typologies within second wave scholarship overlap. It is due to Fein's impact on the field of genocide studies that her typology is the baseline by which I contrast all others.

The central motivation of "retributive genocides" resides in enacting revenge on a social group that poses a threat to the state. Within this second major sub-category I include retributive, revolutionary, wealth, terroristic, and monopolistic genocides. The central aim here stressed by Frank Chalk and Kurt Jonassohn, Israel Charny, Helen Fein, Roger Smith, Barbara Harff and Ted Robert Gurr, and Vahakn Dadrian is the successful domination of an opposition group and its forcible submission through violence and punishment. These cases may include a struggle for power between ethno-religious groups jockeying for control of the state or its resources. It may also manifest itself in the dispossession of a group's land, resources, or wealth.

The central motivation of scapegoat or despotic genocides resides in the overt repression of a minority population whose very presence is deemed to pollute the national identity, pose a threat to internal security, or simply represent a convenient source of blame for all social ills and deprivations of the "superior" group. Stalin's mass murder and

\footnotetext{
143 Harff, Barbara and Ted Robert Gurr, "Toward Empirical Theory of Genocides and Politicides: Identification and Measurement of Cases Since 1945, International Studies Quarterly, Vol. 32, No. 3, (1988) 364-365.

${ }^{144}$ Scott Straus, "Contested meanings and conflicting imperatives: A conceptual analysis of genocide," 352.
} 
deportation of entire populations from the Caucuses included Volga Germans, Kalmyks, Chechens, Ingush, Karachai, Balkars, Meskhetians, and Crimean Tatars, because they posed "security concerns," and were convenient scapegoats of the Stalinist USSR. ${ }^{145}$ Idi Amin's mass killing in Uganda is another unfortunate example of scapegoating domestic social groups for annihilation or expulsion. Here the overriding factor is deep-seeded hatreds, repression, or fear of a population that results in their collective targeting for mass violence. (Table 2.2 shows, most categorizations of genocide fall into identification with victims or perpetrators. This is not surprising as most theories of genocide have centered on those who have been victims of mass violence or its perpetrators, and not necessarily addressed magnitudes of violence).

The central motivation, of "developmental genocide," was most common during colonialism. In virtually every context, colonization and decolonization proved an extremely violent affair. In the Americas, Africa, South and East Asia and Australia, millions of indigenous and first peoples fell victim to colonial conquest. Most scholarship has separated out genocides committed during this long period as a unique phenomenon comparable only amongst other similar endeavors. That being said, we have seen perpetrators of colonial genocides use their empires as laboratories of destruction, testing strategies of mass annihilation and refining them for later use. For example, German conquest of present day Namibia, began in 1885 with the appointment of Dr. Heinrich Göring, father of Hermann Göring a future Nazi leader - "It was [Hermann] Göring who ordered Security Police chief Reinhard Heydrich to organize and coordinate a "total

\footnotetext{
${ }^{145}$ Robert Conquest, The Soviet Deportation of Nationalities (Macmillan, 1960), 74.
} 
solution" to the "Jewish question." 146 The German colonial empire was not the first to develop or employ concentration camps as a means of mass violence, but future Nazi rulers would become its most avid users. German Southwest Africa was home to the empire's first concentration camp, built on December 11, 1904. ${ }^{147}$ German troops under command of General Lothar von Trotha constructed two variants of camps: one was organized around forced labor, and the second was designed with the explicit intent to kill. ${ }^{148}$ It is the latter model that provided the basis for future Nazi concentration camps like Buchenwald and Dachau, argues Benjamin Madley. ${ }^{149}$ German colonial Namibia illustrates a most severe testing of methods of mass violence, though many colonial and decolonization efforts involved variations in the use of extreme violence against indigenous peoples.

The central motivation of the fourth major sub-category, resides in the overt struggle for power between warring ethno-religious-national groups, or regime efforts at state preservation. Here I include intentional genocide, genocidal massacre, hegemonial genocide, and partial, total and "optimal" genocides. Broadly interpreted, these six subtypes exude similar objectives of domination and domestic power politics. They are the personification of a zero-sum game's worst outcome. This fight for power may occur from limited ethnic cleansings of a territory to total annihilation of a population (c.f. Srebrenica,

\footnotetext{
${ }^{146}$ Ben Kiernan, Blood and Soil: A World History of Genocide and Extermination from Sparta to Darfur (New Haven and London: Yale University Press, 2009), 381; United States Holocaust Memorial Museum, "Hermann Göring," accessed on April 18, 2017 from URL: https://www.ushmm.org/wlc/en/article.php?ModuleId=10007112.

147 Benjamin Madley, "From Africa to Auschwitz: How German South West Africa Incubated Ideas and Methods Adopted and Developed by the Nazis in Eastern Europe" European History Quarterly 35:3 (2005) 446.

${ }^{148}$ Ibid, 446.

${ }^{149}$ Ibid, 446.
} 
an ethnic cleansing, to the Holocaust, a total genocide). Power is the explicit factor that ungirds all six sub-categories of genocides here.

Table 2.2

Sub-Categories of Genocide Classification

\begin{tabular}{|c|c|c|c|}
\hline \multicolumn{2}{|c|}{ Membership } & \multicolumn{2}{|c|}{ Magnitude } \\
\hline Victims & Perpetrators & Small-Scale & Large-Scale \\
\hline $\begin{array}{l}\text { biological } \\
\text { genocide } \\
\text { ecological } \\
\quad \text { (or destruction) } \\
\text { genocide } \\
\text { indigenous } \\
\text { genocide } \\
\text { monopolistic } \\
\text { genocide } \\
\text { partial genocide } \\
\text { repressive geno-/ } \\
\text { politicide } \\
\text { revolutionary } \\
\text { geno-/ } \\
\text { politicide } \\
\text { total genocide } \\
\text { wealth genocide* } \\
\text { xenophobic } \\
\text { genocide }\end{array}$ & $\begin{array}{l}\text { auto-genocide } \\
\text { decolonization } \\
\quad \text { genocide } \\
\text { despotic genocide } \\
\text { developmental } \\
\quad \text { genocide } \\
\text { hegemonial geno-/ } \\
\quad \text { politicide } \\
\text { ideological } \\
\text { genocide } \\
\text { institutional } \\
\text { genocide } \\
\text { intentional } \\
\text { genocide } \\
\text { latent genocide } \\
\text { retributive geno-/ } \\
\quad \text { politicide } \\
\text { terroristic } \\
\text { genocide* }\end{array}$ & $\begin{array}{l}\text { genocidal } \\
\text { massacres } \\
\text { utilitarian } \\
\text { genocide }\end{array}$ & $\begin{array}{l}\text { optimal } \\
\text { genocide }\end{array}$ \\
\hline $\begin{array}{l}* \text { Denotes terms creat } \\
\text { category did not provi } \\
\text { category. To reflect th }\end{array}$ & $\begin{array}{l}\text { ne author of this dis } \\
\text { ief title. Therefore, } \\
\text { r's original intent. }\end{array}$ & $\begin{array}{l}\mathrm{n} \text { these cases, th } \\
\mathrm{n} \text { appropriate ac } \\
\text { e list of definitic }\end{array}$ & $\begin{array}{l}\text { author of this sub- } \\
\text { describe this sub- } \\
\text { ided in Appendix B. }\end{array}$ \\
\hline
\end{tabular}

Finally, we are left with singularly developed sub-categories that are narrowly defined to in some instances, identify genocidal events of a single case. Here we group subcategories like auto-genocide, biological, institutional, monopolistic, utilitarian and other mixed sub-categories of genocide. The term auto-genocide was originally developed to 
describe Cambodia's Khmer Rouge killing of its population. Cambodia is labelled an "auto-genocide" because of its exceptional nature where perpetrators and victims share membership in the same community, yet perpetrators engage in self (or "auto") killings against one another. Similarly, as narrow a concept, biological genocide, though misleading, does not pertain to the use of chemical or biological weapons of mass destruction, but what Karl Marx referred to as our first division of labor - the segregation of the sexes and subsequent prevention of a group's ability to procreate from policies of forced "castration, compulsory abortion, and sterilization." ${ }^{150}$ This sub-type of genocide was coined to specifically identity instances of indirect methods of mass group violence detailed in the UN Genocide Convention's Article 2, subparts c through e. This final major grouping holds the remainder of all singularly developed concepts or uncommonly exclusive methods of mass destruction.

Combined, these six major buckets of sub-categories comprise the bulk of second wave research in genocide studies. For decades' scholarly articles and monographs were fixed on classifying genocidal episodes into neat four- or five-part typologies. Eventually this research program would become subsumed by scholars' discontent with existing definitions of genocide and in disaggregation of its sub-types. These theorists forged third wave research whose aim was the coining of substitutive terms for genocide.

\footnotetext{
${ }^{150}$ Martin Shaw, What is Genocide? (Malden, MA: Polity Press, 2007) 76-77; Also see William A. Schabas, Genocide in International Law (Cambridge: Cambridge University Press, 2000) 119-120.
} 


\section{Third Wave: Discontent with "Tradition": Substitutive Terms for Genocide}

In many respects, third wave theorizing has fostered some of our most interesting debates. Scholars in this wave have revisited professor Lemkin's founding assumptions and have updated these to reflect the voracity of modern atrocities. The emergence of third wave scholarship is attributed, largely, to three factors: the hyper-politicization of the "GWord," attempts at clarifying case selection criteria, and professional advancement. Taken together, these motivators have consumed much of the recent scholarship on genocide.

As an educator and researcher of comparative genocide studies, the most common question I confront is: Was (fill in the blank) conflict genocide? This is perhaps the most important of questions a scholar in our field can answer. Despite its brevity, labeling a conflict "genocide" brings about a host of concerns. Classifying conflicts as genocide has, inevitably, become a politically charged act in addition to a scholarly assessment. For instance, undergraduate students from Turkey enrolled in my senior-level "Comparative Genocide" course often ask: Was the Ottoman Empire's treatment of Armenians genocide? To this day, the Turkish government denies the actions of the Ottoman Empire, taken against Armenians during the early part of the twentieth century was genocidal. ${ }^{151}$ Within academic analysis, the Armenian genocide has become one of the "triad" of cases bearing most scholarly attention. ${ }^{152}$ With near uniformity of opinion, Ottoman deportations and massacres of Armenians constitute genocide. Nevertheless, this classification, as practiced by Turkish president Erdoğan, is viewed through an accusatory frame rather than an educational one. The hyper-politicization of the "G-Word," in recent years, has led to an

\footnotetext{
${ }^{151}$ Kifner, “Armenian Genocide of 1915: An Overview.” The New York Times.

${ }^{152}$ Genocide scholars commonly refer to the Holocaust, Rwandan and Armenian genocides as "the triad."
} 
explosion in creation of new terms and substitutive concepts for genocide. This toxicity surrounding the word genocide spawned third wave research. An unfortunate effect of this has specifically been the blurring of case selection criteria, which previously plagued first wave scholars, but now seems to have taken hold in a far-ranging fashion.

With new terms come new criteria. Scholars like David Scheffer, Martin Shaw, Stuart Stein, Mary Anne Warren, Adam Jones, Rudolph Rummel, Daniel Chirot and Clark McCauley, Barbara Harff and Ted Robert Gurr, Benjamin Valentino, Christian Gerlach, Robert Jay Lifton and Erik Markusen, and many others who coined terms listed in Table 2.3, have fundamentally reshaped, expanded, and reinvented genocide studies to include a broader set and range of human activities. This expansion in terms and their definitions, brought two important consequences. First, terms employed by scholars, policymakers, journalists, and governments today, more accurately reflect the circumstances of conflicts in our world than the use of one "catch-all" term, "genocide." Despite this benefit, the second consequence of third wave research has been the muddying of the scientific waters of investigation, comparability and generalizability. With the emergence of nearly 40 new terms to describe human destruction, how might we establish a uniform set of criteria for evaluation? The unfortunate reality is - we cannot (at least, have not, yet).

As an advocate of social scientific research, the most important contribution genocide studies can offer the public is sound, scientific reflections on the causes and consequences of past genocides and their application to present social conditions, with the crucial aim of reducing bloodshed. The first step in achieving this outcome is generalizing the causes of human destruction based on a clear universe of cases. The establishment of operational concepts like culterecide, mass killing, politicide, urbicide, democide, 
collective killing, dekamegamurders, and such, a priori, requires investigators to "address the issue of equivalence by searching for analytically equivalent phenomenona - even if expressed in substantively different terms - across different contexts." ${ }^{153}$ In laymen speak, for analyzing culterecide, which countries and conflicts across time and space should be included for analysis? And, which should not? Without this initial understanding of case selection, genocide scholars cannot take subsequent steps to generalize our findings. The complexities and caveats of third wave research generally undercut our ability to establish quantifiable criteria across these variable terms listed below.

It is impossible to categorize every motivation for why researchers, scholars, and policymakers choose to create new terms. Such projects are usually undertaken with the utmost concern for bettering our collective understanding of social phenomena, particularly, one as important as human conflict. The final motivation mentioned here, is not done to undermine or challenge the motivations of scholars in the third wave - within which this dissertation clearly falls - but it is to shed light on the programmatic nature of our career. Scholarship that creates something new, whether a new term, idea, or theory, is rewarded. Research that does not, is tossed away. Those concerned with our ability to generalize from conflict to conflict should have the utmost concern for conceptual proliferation, as it makes generalizability all the more challenging. As long as assistant professors become associate professors and analysts are promoted to senior analysts on the basis of this paradox of conceptual innovation hindered by definitional disorder will continue to plague our field.

\footnotetext{
${ }^{153}$ Alexander L. George and Andrew Bennett, Case Studies and Theory Development in the Social Sciences (Cambridge and London: MIT Press, 2004) 19.
} 
Table 2.3

Substitute Terms and Categories for Genocide

\begin{tabular}{|c|c|c|c|}
\hline \multicolumn{2}{|c|}{ Membership } & \multicolumn{2}{|c|}{ Magnitude } \\
\hline Victims & Perpetrators & Small-Scale & Large-Scale \\
\hline $\begin{array}{l}\text { atrocity crimes } \\
\text { classicide } \\
\text { cultural genocide } \\
\text { culturecide } \\
\text { ecocide } \\
\text { ethnic cleansing } \\
\text { ethnocide } \\
\text { femicide } \\
\text { (gynocide) } \\
\text { gendercide } \\
\text { holocaust (shoah) } \\
\text { holodomor } \\
\text { infanticide } \\
\text { mass death } \\
\text { mass political } \\
\quad \text { murder } \\
\text { mass violence } \\
\text { murderous } \\
\quad \text { cleansing } \\
\text { nuclear omnicide } \\
\text { political genocide } \\
\text { politicide } \\
\text { population } \\
\text { cleansing } \\
\text { proto-genocide } \\
\text { urbicide }\end{array}$ & $\begin{array}{l}\text { democide } \\
\text { man-made deaths } \\
\text { mass annihilation } \\
\text { mass murder } \\
\text { megapogrom } \\
\text { state crime } \\
\text { vigilantism } \\
\text { zones of violence }\end{array}$ & $\begin{array}{l}\text { collective killing } \\
\text { communalism } \\
\text { mass atrocity } \\
\text { massacre } \\
\text { multicide } \\
\text { pogrom }\end{array}$ & $\begin{array}{l}\text { dekamegamurders } \\
\text { extremely violent } \\
\text { societies } \\
\text { mass categorical } \\
\text { violence } \\
\text { mass killing } \\
\text { megamurders }\end{array}$ \\
\hline
\end{tabular}

Table 2.3 lists substitutive terms that have been coined by political scientists, international law experts, and policymakers, as viable proxies for genocide. I do not claim this to be a complete list of all terms created in place of genocide, but this represents a wide-ranging collection of terms discovered through an investigation of the extant 
literature. The primary criteria used to include a term in Table 2.3 was that it had to be operationalized to address a social phenomenon as severe as genocide. For instance, one British official referred to the present conflict in South Sudan as "tribal genocide." 154 The official used the qualifier "tribal" to describe a type of ethnic atrocities that fall within the scope of genocide. In this sense, the diplomat was not attempting to create a new category or substitute for how we understand and conceive of genocide. Therefore, "tribal genocide" does not appear in Tables 2 or 3. Contrast this with Robert Lifton and Erik Markusen's term "nuclear omnicide." Lifton and Markusen describe the circumstances of nuclear war, often called "nuclear holocaust," with their innovative term. Nuclear omnicide was created to define a new universe of (potential) conflicts, broader then the legal understanding of genocide. Therefore, it is included above.

By the early 2000s, a general consensus emerged on preferences for a select few terms. ${ }^{155}$ Initial substitutes for genocide focused on the limited scope of victim groups (e.g., exclusively, national, ethnic, racial and religious groups). Harff and Gurr used the term "politicide," to refer to a sustained campaign of state-sponsored policies of mass murder aimed at the complete destruction of a population defined by their affiliation or suspected affiliation with a political movement or community. ${ }^{156}$ Comparatively, Rudolph Rummel favored a broader concept that reflected a range of government-led campaigns of mass

\footnotetext{
${ }^{154}$ Rodney Muhumuza, "British official: South Sudan violence is tribal 'genocide," Associated Press. Accessed on April 21, 2017, URL: http://www.hawaiinewsnow.com/story/35139385/british-official-southsudan-violence-is-tribal-genocide.

${ }^{155}$ Hannibal Travis, Genocide, Ethnonationalism, and the United Nations: Exploring the Causes of Mass Killing Since 1945 (New York and London: Routledge, Taylor \& Francis Group, 2013) 28.

${ }^{156}$ Barbara Harff and Ted Robert Gurr, "Systematic Early Warning of Humanitarian Emergencies." Journal of Peace Research Vol. 35, No. 5, (1998) 560.
} 
slaughter. He settled on "democide," demos, meaning populace and -cide, meaning to kill or fall. ${ }^{157}$ Both Harff and Gurr and Rummel were dissatisfied with the complexities of the UNGC's legal definition of one-sided violence, thereby opting to create their own (soon to be widely used) concepts. Politicide and democide reflect an era in which academics maintained their gaze on the role of the state in mass murder but expanded the universe of cases to include other episodes which did not neatly fit within the realm of the UNGC due to the scope of victim groups.

After attempts at expanding the legal description, some scholars returned to focus on classifying genocides which were geographically bounded. After the wars in the former Yugoslavia the term "ethnic cleansing" became academically and socially popularized. ${ }^{158}$ Ethnic cleansing is substantively related to genocide; its essence embodies core notions of the UNGC: the clearing away of a territory from those deemed unworthy through forced relocation, dispossession of personal property, the use of torture, extra-judicial arrest, sexual violence, or murder. ${ }^{159}$ Similar concepts popped up into our lexicon as well, namely, "population cleansing," "murderous cleansing," and "partial genocide" to denote similar catastrophes. The paradox in using such a term as ethnic cleansing is that it labels a process that is anything but clean.

Subsequently, subscribers to the field of genocide studies have increasingly developed better theories to explain the onset and magnitude of mass violence, thus once

\footnotetext{
${ }^{157}$ Rummel, 1990, p. 31.

${ }^{158}$ Benjamin Lieberman, "Ethnic Cleansing versus Genocide?" in Donald Bloxham and A. Dirk Moses, eds., The Oxford Handbook of Genocide Studies (Oxford and New York: Oxford University Press, 2010) 43.

${ }^{159} \mathrm{Ibid}, 44$.
} 
again, initiating new terms into our academic discourse. Benjamin Valentino's work is most notable here, specifically, for introducing the concept of "mass killing." 160 Valentino invented the term, in part, to remove the politics of genocide acknowledgment or the stigmatization that accompanies the label when applying it to contemporary cases. His primary aim is to detail our most severe episodes of human destruction. Mass killing is defined as "the intentional killing of a massive number of noncombatants." 161 What constitutes a massive number? Valentino restricts his focus to conflicts that have resulted in at least 50,000 civilian or non-combatant casualties within a five-year time period. Others have concurrently defined large-scale destruction as "mass violence" or "extreme violence." ${ }^{\prime 162}$ Opting for mass or extreme violence implies a broader range of actions, beyond killing, for example, extra-judicial repression, torture, sexual violence, deportations, kidnappings, disappearances, and including murder. ${ }^{163}$ Nonetheless, these recent concepts have advanced the field significantly.

Finally, the most recent wave of scholars to emerge in Genocide Studies, to which this dissertation belongs, have made efforts to advocate a return to the roots of our field with struggles to maintain professor Lemkin's definitional spirit of genocide, while updating it for the $21^{\text {st }}$ century. Yang Su has chosen to use "collective killing" to designate campaigns of mass slaughter which may be directed by national elites, but in practice have

\footnotetext{
${ }^{160}$ Benjamin Valentino, Paul Huth, and Dylan Balch-Lindsay, “'Draining the Sea': Mass Killing and Guerrilla Warfare," International Organization Vol 58., (2004) 375-407.

${ }^{161}$ Valentino, Final Solutions, 10.

${ }^{162}$ Gerlach, Extremely Violent Societies, 1.

${ }^{163}$ Gerlach, Extremely Violent Societies, 121.
} 
manifested themselves differently across sub-regional levels. ${ }^{164} \mathrm{Su}$ explores variations in collective killing as occurred across the county level in rural China during the Cultural Revolution. Scott Straus gives us "mass categorical violence," an attempt to classify a range of actions beyond simply murder which has persisted across the developing world. Lastly, we have witnessed an explosion in the use of the term "mass atrocities" or "mass atrocity" to reference "widespread and systematic violence against civilians." 165 The use of the mass atrocity label, has garnered much acclaim in recent years, particularly in light of the 2005 "responsibility to protect" document. ${ }^{166}$

Having scolded my colleagues for conceptual malpractice, the final section of this chapter argues that we should situate genocide within a broader understanding of political violence. This reorientation of genocide within a broader field of study, requires a bit of rethinking of our founding assumptions about who its victims are, the scales of atrocities addressed, and the different motivations for enacting extreme violence. Next I introduce the term "mass political violence" in hopes of mitigating some problems discussed above.

\section{What is Mass Political Violence?}

After World War II, most studies of genocide focused on explaining the horrors of the Holocaust and other Nazi genocidal acts. Scholars like Raphael Lemkin, Raul Hilberg,

\footnotetext{
${ }^{164}$ Yang, Collective Killings in Rural China during the Cultural Revolution.

${ }^{165}$ Bridget Conley-Zilkic, "How Mass Atrocities End,” World Peace Foundation, (April 2016) 1-9.

166 Though, The International Commission on Intervention and State Sovereignty (ICISS), the organization designated with drafting the "responsibility to protect" document does not mention the mass atrocity in its text. The term, has become ever more common in recent years, including within the halls of the American Political Science Association and International Studies Association annual conferences with panel titles regularly including mass atrocity after the term genocide, and god knows how many books, articles and journals.
} 
Lucy Dawidowicz, Léon Poliakov, Hannah Arendt, and Saul Friedländer underscored ideological and other existing German social structures, including anti-Semitism, antiCommunism, totalitarianism, the Nazi criminal code, and the wide-ranging dynamics of mass violence that resulted in eliminationist killings of European Jewry, the Roma and Sinti populations, sexual minorities, political opponents, and other marginalized religious groups. ${ }^{167}$ Since this time, two narratives of genocide theorizing took hold. One argues that genocide is a unique phenomenon. ${ }^{168}$ The extreme nature of group eradication makes genocide sui generis to human conflict. ${ }^{169}$ Underlying this narrative are two research camps, exchanging salvos to this day. They agree that the phenomenon of genocide is unique, but in terms of comparative genocide studies, some argue the Holocaust was itself unique within the unique paradigm. ${ }^{170}$ In fact, British historian and Holocaust denier David Irving "claims that the Jewish "Holocaust industry" silences its critics by a combination of intellectual terrorism and moral blackmail and he has taken some of his opponents to court to attempt to provide it." ${ }^{" 171}$ Thankfully, Irving's perspective remains a minority opinion.

\footnotetext{
${ }^{167}$ Lemkin, Axis Rule in Occupied Europe; Raul Hilberg, The Destruction of the European Jews, 3 vol (London: W. H. Allen, 1961); Lucy Dawidowicz, The War Against The Jews, 1933-1945 (New York: Holt, Rinehart and Winston, 1975); Léon Poliakov, Harvest of Hate: The Nazi Program for the Destruction of Jews in Europe (New York: History Library, 1956); Hannah Arendt, The Origins of Totalitarianism (New York: Harcourt Brace Jovanovich, Inc., 1951); Saul Friedländer, Pius XII and the Third Reich: A Documentation (Knopf, 1966).

${ }^{168}$ Steven Katz, The Holocaust in Historical Context (New York and Oxford: Oxford University Press, 1994).

${ }^{169}$ Israel Charny points out the difficulty in studying genocide, particularly when interviewing survivors of the Holocaust or Armenian genocide when they contend their punishments were "unique" in Samuel Totten, William S. Parsons, and Israel W. Charny, eds., Century of Genocide: Critical Essays and Eyewitness Accounts, Second Edition (New York and London: Routledge, 2004).

${ }^{170}$ Gunnar Heinsohn, "What makes the Holocaust a uniquely unique genocide? Journal of Genocide Studies $2: 3$ (2000) 411-430.

${ }^{171}$ Norman Finkelstein, “The Holocaust industry” Index on Censorship 29:2 (2000) 120-130.
} 
Conversely, others contend all genocides are exceptional and should be analytically compared to identify patterns of common casual pathways.

Our second academic narrative argues genocide is an extension of existing levels of violence. ${ }^{172}$ It is now a widely accepted maxim that war and genocide often co-exist. ${ }^{173}$ Building on this revelation, some researchers have sought connections with other parallel fields, like political violence, civil wars, state repression, human rights, counterterrorism, counterinsurgency, and geography. ${ }^{174}$ They argue that comparative genocide studies must embrace its interdisciplinary nature and pull from a variety of research disciplines so that we can understand human suffering from a holistic perspective. This dissertation fits squarely within the latter camp and is the reason I operationalize the term "mass political violence" below.

I will argue genocidal violence should be examined in relation to other forms of extreme violence. In solidifying my argument, this dissertation uses a broader term, mass

\footnotetext{
${ }^{172}$ Ernesto Verdeja, "On Situating the Study of Genocide within Political Violence," Genocide Studies and Prevention 7:1 (Spring 2012) 81-88.

173 The exact connection and causal nature of war and genocide is still hotly debated, however, see Martin Shaw, War \& Genocide (Cambridge: Polity Press, 2003); Christopher R. Browning, The Origins of the Final Solution: The Evolution of Nazi Jewish Policy, September 1939-March 1942 (Lincoln, NE: U of Nebraska P, 2004); Scott Straus, The Order of Genocide: Race, Power and War in Rwanda (Ithaca, NY: Cornell UP, 2006); Donald Bloxham, "The Armenian Genocide of 1915-1916: Cumulative Radicalization and the Development of a Destruction Policy," Past and Present 181 (Nov 2003): 141-92; Manus Midlarsky, "The Demographics of Genocide: Refugees and Territorial Loss in the Mass Murder of European Jewry," Journal of Peace Research 42 (Jul 2005): 375-91.
}

174 Adam Jones, "Genocide as Political Violence" in Marie Breen-Smyth, ed., The Ashgate Research Companion to Political Violence (London and New York: Routledge, 2012); Mahmood Mamdani, The Politics of Naming: Genocide, Civil War, Insurgency (London: London Review of Books, 2007); Franklin Watts, Civil War and Genocide (Hachette Children's Group, forthcoming in 2018); Marcia Esparza, Henry R. Huttenbach, and Daniel Feierstein, eds., State Violence and Genocide in Latin America: The Cold War Years (New York: Routledge, 2010); Kurt Jonassohn and Karin Solveig Björnson, Genocide and Gross Human Rights Violations: In Comparative Perspective (New Brunswick, NJ and London: Transaction Publishers, Inc., 1998); Valentino, Final Solutions; James A. Tyner, The Killing of Cambodia: Geography, Genocide and the Unmaking of Space (Burlington, VT: Ashgate Publishing Limited, 2008). 
political violence (MPV), as a heuristic device in situating genocide as an extension of current forms of political violence. By employing the term MPV, it is my intellectual desire to address many episodes of mass violence as listed in Table 3. MPV is a multidimensional concept. Its primary benefits lie in the reality that its usage allows us to circumvent debates over terminology such as mass killing versus mass murder, collective killing versus classicide, or mass atrocity versus politicide, for instance. MPV, as shortly defined, is versatile enough to generalize across all substitutive categories.

I define mass political violence as the intentional killing, in whole or part, of a discernible group, by a government, its agents, or an organized social unit. There are four central characteristics of MPV. First, for the purpose of this dissertation, violence is defined as killing. There are alternative ways of examining political violence, including rape as a weapon of war, torture, terrorism (with or without killing), and maiming. This dissertation exclusively focuses on the killing component of violence and leaves the remaining categories of study for others to assess. The concept of "violence" has become so widely used, that a nearly 1,300-page handbook has been devoted to its study. ${ }^{175}$ In compiling the International Handbook of Violence Research Wilhelm Heitmeyer and John Hagan note:

Almost all relatively detailed studies make it clear that violence takes extremely varied forms and may possess many different qualities; not only is there a very substantial range of (current) definitions, but there are also many disagreements about the authority of definitions of what violence is, or is said to be. Consequently, theories of violence not only vary in their validity and significance but also address different subjects and involve controversial assessments of the efficacy of possible strategies for addressing the problem. Moreover, what seems the clear condemnation of violence is significantly challenged in many social and political situations,

\footnotetext{
${ }^{175}$ See Wilhelm Heitmeyer and John Hagan, eds., International Handbook of Violence Research (Springer-
} Science+Business Media, B.V., 2003). 
so that it is highly advisable to approach violence, and its different areas and contexts, on a basis of clear distinctions...

This dissertation is centrally concerned with the study of mass political violence.

That means, a study that includes by definition, many forms of violence (i.e., genocide, mass murder, tyranny, despotism, oppression, democide, and more). The use of the term "violence" enables a broader avenue for the study of large-scale destructive policies aimed at civilian populations.

One of the central problems confronting a manual on violence is the ambiguity of violence itself, which is apparent in the characterization and framing of its phenomena, the logic of its occurrence and possible escalation, supposed causal explanations, and its evaluation. As a result, it frequently happens that clear divisions between levels of analysis and escalation dynamics become blurred, with the result that analyses cease to do justice to the complexity of violence. The problems of violence research begin at the outset, with the attempt to determine exactly what should be classified as violence.

There is, admittedly, a broad consensus that violence causes injury and sometimes death and results in many different forms of destruction, so that there are always victims. But at that point, if not before, the consensus certainly ends. It is not even clear precisely who or what has been injured, or how serious that injury is. Can cases of mental devastation be classified as violence, or-because they cannot be objectively recorded-are they merely subjectively nuanced injuries, where the victims themselves may even come under suspicion? Should the definition of violence include structural forms, which need no direct perpetrators but undeniably produce their victims, or is the use of the label "structural violence" merely denunciatory?"176

As addressed by Heitmeyer and Hagan, violence may take many forms, from verbal assaults and dehumanization campaigns on one end, to eliminationist murders on the other.

For the purpose of scientific rigor, case studies for this dissertation are selected on the basis of killing, but, mass rape, dehumanization rhetoric, torture, discriminatory campaigns of

\footnotetext{
${ }^{176}$ Heitmeyer and Hagan, International Handbook of Violence Research, 3-4, emphasis added.
} 
marginalization, and other forms of violence will be discussed on a case by case basis, when such forms of violence exist. In pursuit of creating scientific standards for including episodes of MPV, the universe of cases, is in part, determined by the number of victims killed by perpetrators. For example, within the Nazi dominion from 1933-1945, perpetrators systematically killed millions of citizens and prisoners of war who did not have a "place" within the Hitler's vision of the post-war order. In addition to mass murder, Nazi officials and their minions, carried out appalling "medical" experiments and torture on countless human beings. ${ }^{177}$ This is perhaps the most notorious example of violence enacted on a targeted population. These events would be discussed under MPV, however, they would not be part of criteria in determining a case's eligibility for inclusion. Simply because, these circumstances and violent episodes are all too common and difficult in creating measurable criteria.

Second, deaths attributed to perpetrators of MPV must be intentional. Establishing intent has been a long held characteristic of genocide and its many forms of violence. From Raphael Lemkin's Axis Rule in Occupied Europe to the UN Genocide Convention, intent to kill, exterminate, liquidate, or otherwise dispose of a social group, has been central to studying this phenomenon. Professor Lemkin suggested genocide is a product of the intentional "extermination of nations and ethnic groups" in his seminal work, and the UNGC explicitly declares genocide to be "acts committed with intent to destroy." ${ }^{178}$ It is

\footnotetext{
177 Vivien Spitz, Doctors from Hell: The Horrific Account of Nazi Experiments on Humans (Boulder, CO: Sentient Publications, 2005); Matthew Lippman, "The Nazi Doctors Trial and the International Prohibition on Medical Involvement in Torture," Loyola of Los Angeles International and Comparative Law Review 2:1 (1993) 395-441.

${ }^{178}$ Lemkin, Axis Rule in Occupied Europe, xi; Convention on the Prevention and Punishment of the Crime of Genocide, Article 2.
} 
the intention of perpetrators who target individuals that distinguishes MPV and genocide from other forms of mass death caused by disease, Mother Nature, or the collateral damage of unintentionally killing civilians. ${ }^{179}$ Similar to the UNGC, intentional acts of MPV are not restricted to "direct" methods of violence, such as homicide, hanging, gassing, or bombing. It includes any act that deliberately inflicts on a group "conditions of life calculated to bring about its physical destruction," such as starvation, exposure, disease, deportation, forced labor, man-made famine, prevention of births, or removal of children from one group to another group. ${ }^{180}$ Irrespective of perpetrators' methods of violence, the presence of intent to harm members of a group, qualifies a conflict's eligibility for inclusion as MPV. Determining, let alone proving the intention driving violence due to direct or indirect methods of perpetrators can be a nearly insurmountable task for academics and jurists. The difficulty of this characteristic is explained above, as the first problem of defining genocide. Therefore, little needs added here, except to reiterate, its difficulties in assessing perpetrator motivations.

The third aspect of the definition of MPV resides in assessing potential victim populations. I refuse to specify protected classes of victims in the definition of MPV. This is in stark contrast to the UNGC's explicit statement that genocide can only be committed against a national, racial, ethnic or religious group. I take a comprehensive and inclusive stance on the potential victims of mass political violence. By specifying the eligibility of victim groups, authors and legal scholars, either intentionally or unintentionally exclude marginalized groups from protection. This is the case with the UNGC's exclusion of sexual

\footnotetext{
179 This distinction is made clear by Benjamin Valentino, Final Solutions, 10.

${ }^{180}$ Convention on the Prevention and Punishment of the Crime of Genocide, Article 2(c).
} 
minorities, genders, and politically motivated killings. For reasons of intellectual and social inclusion, MPV can be employed against any "discernible group." The qualifier "discernible," is used to cover objective and subjective groups. If a group is objectively discernible, for example, a group of individuals who openly identify as Christian or gay or lesbian, then they should be considered eligible to study as being the victims of MPV. On the other hand, if perpetrators incorrectly, but subjectively, believe a group of individuals to be part of a social group, for example, accused communists in Indonesia (1965-66) or accused capitalists in China (1949-1976), even if they are simply not members, they will be included for study as well. Limiting the definition of MPV (or genocide) would marginalize similarly targeted groups were exiled from inclusion before, which is not my intention.

Let me say a brief word on the use of the term "political." Based on the examples above, violence directed against a religious, communal, sexual minority, or another group may or may not be directly "political" as we academically conceptualize it. I have chosen to use the term political to represent all activities relating to societal and governmental, public affairs within a country. The common phrase, "the personal is political" comes to mind. In this vein I operationalize mass political violence to be violence used and directed by perpetrators (of which there are four principal categories) against a target population for any number of reasons. The use of political is not meant to restrict our analysis to specific groups targeted for political gain. On the contrary, it is intended to broaden our discussion of a wide swath of group violence employed by perpetrators of extreme violence.

The final aspect of the definition of mass political violence resides in setting a threshold of violence. I have made an argument for situating genocide and MPV within a 
broader field of political violence studies. In order to defend this repositioning, and the conceptual distinction of MPV, I define the word "mass," in mass political violence, to be the killing of at least 10,000 civilians or noncombatants within a 12-month span. Let me be clear, I do not deny that genocidal events can consume a population of less than this threshold. Nor do I argue that conflicts which result in fewer deaths are any less atrocious then large-scale killings. There are two reasons for setting a threshold. First, creating a threshold for violence is one manner to distinguish "normal" policies and episodes of political violence (e.g., extra-judicial killings, torture, mob violence, lethal riots, and so on) from systematic, organized campaigns of violence that specifically target a social group. Violence that reaches such a level within one year, is most likely the outcome of intentional policies of group elimination and therefore of a wholly different nature than "normal" levels of political violence. Second, the use of a threshold allows for a consistent, measureable and standardized criterion in labelling conflicts. Consistency in selecting case studies matters for generalizing results and avoiding the politicization of conflicts. It allows for the author to assess comparable cases across time and span, with relative certainty that violence in each conflict reached comparable heights and were a product of similar preconditions and causal factors. It is for these reasons I utilize a threshold requirement. 


\section{CHAPTER III:}

\section{THE CAUSES AND CONSEQUENCES OF MASS POLITICAL VIOLENCE}

"Murder is human... genocide is not."

- Gideon Hausner, $1981^{181}$

"Men make their own history, but they do not make it as they please; they do not make it under self-selected circumstances, but under circumstances existing already, given and transmitted from the past."

- Karl Marx, $1852^{182}$

"What we are is shaped both by the broad systems that govern our lives-wealth and poverty, geography and climate, historical epoch, cultural, political and religious dominance-and by the specific situations we deal with daily."

- Philip Zimbardo, $2007^{183}$

\section{Introduction}

In this chapter I ask two basic questions: under what conditions do perpetrators in society opt for mass political violence? And, how do they sustain mass political violence

\footnotetext{
${ }^{181}$ Gideon Hausner, former prosecutor against Adolf Eichmann. Excerpt from interview, WPBH video "The Hunter and the Hunted" (PBS 1981), quoted in Stephen C. Feinstein, ed., Absence/Presence: Critical Essays on the Artistic Memory of the Holocaust (Syracuse, NY: Syracuse University Press, 2005), xxi.

182 Robert C. Tucker, ed. "The Eighteenth Brumaire of Louis Bonaparte," in The Marx-Engels Reader, Second Edition (New York: W.W. Norton \& Company, 1978), p. 595.

183 Philip Zimbardo, The Lucifer Effect: Understanding How Good People Turn Evil (New York: The Random House Publishing Group, 2008), p. 298.
} 
over time? I will take each question in turn. First, to identify societies at risk of mass political violence (MPV), we might employ a criminological perspective, asking what are the motives, means, and opportunities for perpetrators in a given context. Pinpointing perpetrator ideological beliefs would be one priority in unpacking possible motives. Harken back to inter-war Germany where society was imbued with notions of antisemitism that permeated nearly all aspects of life: Germans were taught to blame Jews for Germany's defeat in WWI and subsequent decline. This scapegoating came from the administrative state, and was echoed in many churches across the continent. National Socialism of the 1930s took advantage of this particularly violent strain of "eliminationist antisemitism" by tapping into preexisting beliefs, values, and attitudes towards Jews. This deep ideological belief, held by many, could have been a key motivating factor in the Holocaust and other Nazi genocidal atrocities. That said, antisemitism by itself is insufficient to explain the totality of National Socialism's genocidal violence. Antisemitism was indeed a unifying credo among many Germans. However, running parallel to this national attitude were individual psychological reasons for participation in the Holocaust. Most Germans viewed the dispossession of Jewish businesses and property as "an once-in-a-lifetime opportunity" to enrich themselves at the expense of their Jewish neighbors. ${ }^{184}$ In many of these cases German proprietors may have sympathized with anti-Semitic attitudes, but individual financial greed coupled with opportunity were triggers for violence. Greed is just one of dozens of psychological dispositions that have been catalogued to encourage people to commit violence against one another.

${ }^{184}$ Adam Jones, Genocide: Comprehensive Introduction, $2^{\text {nd }}$ Edition (London and New York: Routledge, 2011), 387. 
Most theories revolve in some way around the assessment of perpetrator motivations coupled with their ability to enact violence (i.e., the means). There is often a confluence of motives and opportunities, as discussed. Any cursory search of academic literature on the causes of genocide would return thousands of results explaining in granular detail ideological motivations of individuals and societies. However, investigating individual motives for violence can be a slippery slope. Many social scientists, including myself, contend human beings engage in violence for a variety of reasons including, but not limited to, greed, grievance, frustration-aggression, revenge, love, convenience, simple fear, fear of polluting one's group, anger, hate, shame and humiliation, disgust, essentialization, prejudice, establishing dominance, hierarchy or independence, realpolitik, scapegoating, social cleavages, deep-seated hatreds, and for any other reasons. ${ }^{185}$ Perhaps most pertinent to this study is the question of the circumstances under which violence is wielded in a specific, quasi-organized fashion that result in massive numbers of fatalities. If operating from the assumption that violence is first and foremost instrumental, thereby tied to elite or mass goals, establishing a unified theory of mass political violence based on the "strategic" goals of individuals is inherently difficult, as human goals may change from decade to decade or even week to week. Rather than asking why people kill - because such a list is never ending - we should ask what conditions enable people to kill on a large scale.

\footnotetext{
${ }^{185}$ The following is a survey of the literature on such motivations: Paul Collier and Anke Hoeffler, "Greed and grievance in civil war" Oxford Economic Papers 56:4 (2004), 563-595; Peter Uvin, Aiding Violence: The Development Enterprise in Rwanda (West Hartford, CT: Kumarian Press, 1998); Ervin Staub, The Roots of Evil: The Origins of Genocide and Other Group Violence (New York: Cambridge University Press, 1989); Daniel Chirot and Clark McCauley, Why Not Kill Them All? The Logic and Prevention of Mass Political Murder (Princeton and Oxford: Princeton University Press, 2006); Mahmood Mamdani, When Victims Become Killers: Colonialism, Nativism, and the Genocide in Rwanda (Princeton: Princeton University Press, 2001); Manus I. Midlarsky, The Killing Trap: Genocide in the Twentieth Century (Cambridge: Cambridge University Press, 2005); Noah R. Bassil, The Post-Colonial State and Civil War in Sudan: The Origins of Conflict in Darfur (London: I.B. Tauris, 2013).
} 
Understanding the conditions that give rise to mass violence will yield analytically more fruitful responses than scholarly attempts at unpacking the psychology of individual perpetrators? Therefore, isolating particular motives is not the most efficient way of identifying societies at risk of mass political violence.

Because agents are largely bound by their physical, and to some extent social environments, theorizing these constraints is vital to explaining why violence occurs or is prevented in society. In other words, rather than emphasizing "motives and means," I stress the role "opportunity" plays in the development of violence. The social scientific term for my approach would be "dynamic structuralism." I define dynamic structuralism as an approach that examines both slowly changing variables - i.e., structural factors - like a regime's military capacity, ideology, infrastructure and bureaucratic state capacity, civic tolerance, or social cleavages, along with dynamic processes such as exogenous shocks to society as in terrorism, armed conflict, assassination, or economic collapse.

Therefore, in assessing state-society relations before, during, and after episodes of mass political violence, I build a model that uses three variables combined with estimates of perpetrator tactics and stratagems (the dynamic "agency" oriented processes) to determine the likelihood of mass political violence onset. For violence to reach a level of 10,000 or more victims within a 12-month period, these structures (i.e., regime power, state capacity, and social appetite for violence) must interact in specific ways to facilitate such desires. Two structural factors reflect the role of the state and one of society. Mass political violence can emerge during armed conflict or its absence, in developed or developing economies, and in (ethnically) heterogeneous or homogenous states. Thus, rather than over complicating our model of MPV onset, I rely on three principal variables that are most 
likely to enable potential perpetrators to turn violent. Savvy perpetrators of mass political violence use state and societal indicators as a means of triangulating their window of opportunity. Any perpetrator dead set on enacting violence can attempt so at any time, irrespective of these social structures. This chapter unpacks how each of these conditions, when interacting at particular levels, create the conditions under which determined perpetrators are able to commit mass political violence. Despite all my edits, I'm following you, the model makes sense to me.

\section{A Typology of Mass Political Violence}

\section{Assumptions and Debates in Theory Building}

There has been much progress within Comparative Genocide Studies since the end of the Cold War. In the last three decades, we have seen a virtual tsunami of interest in theory development, non-major case analysis, and social activism on the part of faculty and students and in non-governmental organizations like Save Darfur, The Enough Project, and Genocide Watch. ${ }^{186}$ With these additional resources, scholars have pursued new avenues of research. The comparative method is an ideal framework for addressing these emerging areas. One principal aim of theory building and comparative research lies in our ability to generalize. ${ }^{187}$ To accomplish this, one tendency has been to distil complex theories into parsimonious models of human behavior. To this end, most scholars have

\footnotetext{
186 The Holocaust, Armenian and Rwandan genocides are traditionally considered major case studies. The triad, as they are commonly known, encompasses the bulk of research to date.

${ }^{187}$ Prior to the 1970 s there was scant research on comparative case studies. Most research addressed single case studies or definitional problems.
} 
relied upon some decades-old assumptions in framing their analysis. In this section, I argue that we need to rethink these conventional assumptions that permeate the field.

Israel Charny asks, "Can there be any case of mass murder which is not genocide?" ${ }^{188}$ His conclusion is unequivocal - no. As articulated in the previous chapter, I argue that not all mass murder is genocide, but all mass murder deserves analysis. For Comparative Genocide Studies to advance our understanding of the mass violence, there must be an assumption that all genocides are - directly or indirectly - comparable on some level. If they were not, then what good is having a research program devoted to its study? This (mis)perception of comparability has dogged the field for decades. Giovanni Sartori warned of the "conceptual element problem" in his seminal work on concept misformation, conceptual stretching, and ladders of abstraction. ${ }^{189}$ As Sartori noted, concepts can be used in a very general or a very specific manner. Genocide is an "empirical concept," meaning it "can be located at, and moved along, very different points of a ladder of abstraction." 190 Nazi Germany and Cambodia under the Khmer Rouge are empirical examples of genocide in the twentieth century. Both episodes display similar characteristics of a "class of things," as Sartori would maintain. ${ }^{191}$ In each case, perpetrators systematically murdered ethnic, national, religious, and political opponents. Each government sought a fundamental transformation of society - where killing was only one of the means to achieve a utopian

\footnotetext{
${ }^{188}$ Israel W. Charny, in foreword of Alan S. Rosenbaum eds., Is the Holocaust Unique? Perspectives on Comparative Genocide (Boulder, CO: Westview Press Inc., 1996), p. x.

189 Giovanni Sartori, "Concept Misformation in Comparative Politics," The American Political Science Review 64:4 (December 1970), 1033-1053.

${ }^{190}$ Sartori, 1970, 1041.

191 This phrase, "class of things," is used to describe the relationship between higher and lower levels of abstraction. Sartori quotes from Wesley C. Salmon, Logic (Englewood Cliffs: Prentice-Hall, 1963), p. 90-91.
} 
vision. The comparison between Nazi Germany and Cambodia is useful and logically valid in distinguishing between genocidal and non-genocidal events. However, once stepping inside the universe of genocide cases, we should ask: are the Holocaust and Cambodia truly comparable in its causes and consequences? I will argue that most literature of Comparative Genocide Studies operates at a high level of abstraction, meaning scholars engage in comparisons of the broadest sense. What we must do to gain more clarity is to climb down this ladder of abstraction toward specificity, and to disaggregate cases of genocide and mass political violence into similar classifications based on their causes of violence. I will argue that the Holocaust and Cambodia are examples of two different kinds of genocide and mass political violence. Understanding these refined differences in great detail will enhance our analytical leverage in assessing the causes and consequences of mass political violence. The first step toward this nuanced approach lies in rejecting the assumption that all mass political violence episodes possess similar beginnings, middles, and ends to violence.

Why compare Nazi genocidal atrocities against Jews and other ethno-religious minorities with Mao's Great Leap forward or the Cultural Revolution? There are many logical and methodological reasons to make this comparison. First, any study of the twentieth century's bloodiest regimes, in terms of the sheer number of victims, must include Nazi Germany and Communist China. Each state was prototypical of a totalitarian regime. ${ }^{192}$ Under Hitler and Mao's tutelage, each governing party retained de jure and de facto authority. Each despot articulated a guiding ideology for society, an ideology that

\footnotetext{
${ }^{192}$ Using Juan Linz and Alfred Stepan's characteristics of totalitarian regimes in Problems of Democratic Transition and Consolidation: Southern Europe, South America, and Post-Communist Europe.
} 
sought fundamental transformations of current circumstances to an obtainable utopia. Finally, each regime stimulated mass mobilizations across its territory. Private life became yesteryear, and the party was all encompassing. In this sense, Nazi Germany and China are directly comparable with respect to the role of the state.

Scholars like R.J. Rummel compare these cases based on their devastating power. Rummel classifies each episode as a dekamegamurders, which roughly translates to "murderer of tens of millions."193 Rummel is correct to study Nazi Germany and China under the premise of the twentieth century's most heinous murdering regimes. As shown, there are methodological reasons (i.e., isolating regime type) and logical reasons (i.e., from a victimological perspective) to compare Hitler's Third Reich with Mao's People's Republic of China. Therefore, why do I argue that existing classifications are not sufficient? As will be demonstrated, regime type and sustained killing capacity are not ideal factors in arranging comparisons between genocides and mass political violence episodes. Such comparisons are too facile. To understand the differences between these preeminent cases, we must unpack the role of the state in the implementation of violence. Here is where we find intrinsic and crucial differences that undergird my typology and more importantly nuances of the state in the contemporary world.

The assumption that states function similarly is reasonable given an investigatory requirement that some factors remain constant over time. However, this analytically valid belief largely simplifies the role states play today. For example, Hervé Savon, a French sociologist, developed a typology for classifying genocide into three categories:

${ }^{193}$ Rummel, 1990, p. xviii. 
substitution, devastation, and elimination. ${ }^{194}$ The outcomes in each episode are different but the inputs (i.e., state and perpetrators) are viewed as homogenous. States propagate violence based on three motivations according to Savon - substitution, devastation, or elimination - and their actions result in one of three possible outcomes. The only difference in state behavior lies in the tactics used to reach these outcomes, but tactics are not considered fundamental variations in state behavior. In The Killing Trap, Manus Midlarsky's aim was to "pinpoint" the reasons small-scale massacres can be transformed into large-scale genocides. ${ }^{195}$ In his comparative analysis of mainly three cases - the Holocaust, the Armenians, and Tutsis - Midlarsky assumes state behavior originates with elite impressions of loss, continues through a complex process of risk evaluation, and ends with decision-makers concluding the ideal mechanism for minimizing their perception of loss is through genocidal acts. ${ }^{196}$ Even in Daniel Feierstein's Genocide as Social Practice, we see the assumption of state similarity implicitly applied. Feierstein compares the policies of Argentine's military junta with that of Nazi Germany - drawing similarities between the goals of each perpetrating government.

Skeptics may argue that notable authors like Helen Fein, Barbara Harff, and others have developed typologies to explain variation in the alleged homogeneity of state behavior. But these typologies merely disaggregate episodes along the lines of state

\footnotetext{
${ }^{194}$ Hervé Savon, Du cannibalisme au genocide (Paris: Hachette, 1972). Summarized by Frank Chalk and Kurt Jonassohn, The History and Sociology of Genocide: Analysis and Case Studies (New Haven and London: Montreal Institute for Genocide Studies and Yale University Press, 1990), p. 13.

${ }^{195}$ Manus I. Midlarsky, The Killing Trap: Genocide in the Twentieth Century (Cambridge: Cambridge University Press, 2005).

${ }^{196}$ Ibid, see chapter five in The Killing Trap for an explanation of Midlarsky's theoretical framework.
} 
motivations, and not by perpetrator composition or their precise role in enacting violence. Fein separates genocides into four categories: ideological, retributive, developmental, and despotic. What is common to all episodes is perpetrator intent to eliminate a substantial number of people of a social group. The literature is shrouded with endless examples of research resting upon the assumption that state behavior remains relatively homogenous. I challenge this assumption in my typological framework. By triangulating between state and society involvement in mass political violence we unpack four discrete, often obscured categories. Each quadrant of the typology reflects a different combination of state-society relations that enables particular types of perpetrators to become activated - see table 3.1 below.

Table 3.1

A Typological Framework of Mass Political Violence Perpetrators

\begin{tabular}{|c|c|c|c|}
\hline & & \multicolumn{2}{|c|}{ Societal Participation } \\
\hline & & Low & High \\
\hline \multirow{2}{*}{$\begin{array}{l} \\
\\
0\end{array}$} & ton & $\begin{array}{l}\qquad \text { The State } \\
\text { Government: principal perpetrator } \\
\text { Societal: opportunism, } \\
\text { bandwagoning } \\
\text { Sustained killing capacity: high }\end{array}$ & $\begin{array}{l}\quad \text { State-Society Coalition } \\
\text { Government: co-perpetrator } \\
\text { Societal: co-perpetrator, militias, etc. } \\
\text { Sustained killing capacity: high }\end{array}$ \\
\hline & 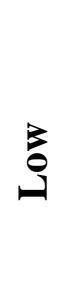 & $\begin{array}{l}\quad \text { Non-State Actors } \\
\text { Government: none } \\
\text { Societal: non-state armed groups } \\
\text { Sustained killing capacity: low }\end{array}$ & $\begin{array}{l}\quad \text { State-Sponsored Groups } \\
\text { Government: enabler, clandestine } \\
\text { Societal: principal frontline } \\
\text { perpetrator } \\
\text { Sustained killing capacity: moderate }\end{array}$ \\
\hline
\end{tabular}


Second, while many researchers have over-simplified the role of the state in mass political violence studies the same cannot be said of its antecedent causes. In fact, as Scott Straus recently writes, there are far too many variables used to predict when and where genocide will emerge. ${ }^{197}$ A cursory review of pertinent risk factors for genocide and mass political violence onset generates dozens of "exacerbating" factors. ${ }^{198}$ Much of Comparative Genocide Studies scholarship suffers from this dilemma - "frequency mismatch.” According to Finkel and Straus, theories suffer from frequency mismatch when they employ causal variables or exacerbating circumstances that commonly exist in the world outside of genocidal contexts. ${ }^{199}$ For instance, many societies possess deep-seated hatreds among and between social groups. The conflict in Northern Ireland raged for more than three decades with episodic tit-for-tat killings between loyalist paramilitaries targeting Catholics, and Irish nationalist forces carrying out deadly bombings and terrorist attacks throughout the United Kingdom. The 2007 electoral violence in Kenya largely occurred along socio-political divides and nearly fomented a collapse of the democratic order. Even the United States, a consolidated democracy, is not immune from the scourge of deeply

\footnotetext{
${ }^{197}$ Scott Straus, Fundamentals of Genocide and Mass Atrocity Prevention (Washington, DC: United States Holocaust Memorial Museum, 2015), 53-90.

${ }^{198}$ This is not an exhaustive list of risk factors for genocidal violence but a representative sample: armed
conflict (or) war; assassinations; authoritarianism; convenience and opportunity; deep-seated hatred;
dehumanization and deindividuation; discriminatory legislation; economic causes (numerous); ethno-cultural
elite; existing discrimination against a particular group; fear (simple and of pollution); fragile, weak or state
collapses; frustration-aggression; government capabilities; greed and grievance; high infant mortality;
ideology (exclusionary or transformative); large-scale instability; low-trade openness; nonviolent protests;
outlawing political parties; percentage of GDP spent on military; polarized society; political and social
upheaval; prior genocide or mass atrocities; realpolitik and risk minimization; regime type (all); religious
motivations; revenge; rigged elections; sadism; size of the military; state capacity; stockpiling weapons;
totalitarianism; triggering events or windows of opportunities; or youth indoctrination.
}

${ }^{199}$ Evgeny Finkel and Scott Straus, "Macro, Meso, and Micro Research on Genocide: Gains, Shortcomings, and Future Areas of Inquiry," Genocide Studies and Prevention 7:1 (Spring 2012), p. 63. 
divided societies. Ideological tribalism dominates American politics with political affiliation determining which social circles a person navigates. Yet none of these societies experienced MPV as defined here. Intergroup animus is far more common in societies across the globe than states experiencing mass political violence and genocide. Therefore, existing theories have been unable to assess when this (and other) risk factors might trigger mass violence. The abundance of societies possessing any number of likely risk factors greatly exceeds the number of states who devolve into large-scale mass murder. This frequency mismatch has plagued Comparative Genocide Studies since its founding.

Related to frequency mismatch is our collective inability to accurately predict tipping points for mass political violence. The problem with these variables is that they are often slowly changing factors. ${ }^{200}$ For example, a state's ethno-religious composition is likely to remain constant over the short term; changes in population growth may come over time, but slowly. Yet, deep-seated (primordial or instrumental) ethnic tensions have been the backbone of theories for decades. The Rwandan genocide is often mooted as the archetypal ethnic conflict. One, among many, problems with this example lies in the fact that Rwanda's ethnic composition remained relatively consistent throughout the latter half of the twentieth century. If ethnicity caused the 1994 genocide, why did this slowly changing variable precipitate mass political violence in 1994 and not 1973 or 1985? To extend the example further, if ethnic divisions between Hutus and Tutsi caused - either partly or wholly - the Rwandan genocide, why did Burundi who possessed near identical ethnic demographics not descend into genocide along with Rwanda? The answer to these

\footnotetext{
${ }^{200}$ Scott Straus, Fundamentals of Genocide and Mass Atrocity Prevention (Washington, DC: United States Holocaust Memorial Museum, 2015), p. 53.
} 
questions obviously means ethnic composition cannot be understood as a triggering factor in the onset of genocide in a particular context. This leads to two theoretical conclusions: Either another factor was working in conjunction with ethnic divisionism, or we have yet to understand the role ethnicity plays in such contexts. This problem is endemic to the study of genocide and mass political violence generally. It is precisely this problem that led to my approach to the study of mass political violence - namely, a "dynamic structural" analysis of state-society conditions before, during, and after mass political violence.

\section{On Perpetrators}

The publication of Christopher Browning's Ordinary Men sparked one of the most influential and contentious debates on the issue of why and how individuals become perpetrators. In his 1992 book, Browning methodically defines his “ordinary men" thesis by examining the men of German Reserve Police Battalion 101 who murdered and rounded up Jews for deportation to Nazi concentration camps in 1942 Poland. Browning found that the men of Reserve Battalion 101 were not ideologically committed, card carrying Nazis, and nor were they inherently more sadistic than their contemporary German brethren. Unit 101 was comprised of otherwise ordinary middle-aged, working-class men who had been drafted for military service, but found ineligible to serve. Browning's thesis argues that otherwise "ordinary" persons placed in certain circumstances (i.e., within an authoritarian structure) might commit heinous crimes, including cold blooded murder, torture, and terror. The men of Unit 101 did not engage in these monstrous crimes for fundamentally nefarious reasons, but even more disturbingly, from their perspective, enacted violence because of a basic sense of obedience to authority and in response to peer pressure. Daniel Goldhagen 
reignited the debate in 1996 with the publication of his book Hitler's Willing Executioners in which he argued against Browning's "ordinary men" thesis. For Goldhagen, the genesis of the Holocaust and Nazi genocidal atrocities can be traced to a particularly violent strain of antisemitism - an eliminationist outlook. Goldhagen argues that both ordinary and elite Germans were influenced by this eliminationist antisemitism and therefore those who participated in the perpetration of the Holocaust willingly acting upon this preexisting belief structure.

In an attempt to transcend this case-specific debate about the motives of perpetrators, I ask two questions that assess the social composition of perpetrators. First, what criteria do we use in defining a perpetrator? In other words, who counts as a perpetrator of mass political violence and who does not. This question has both pragmatic and theoretical implications. If our goal is prosecutorial justice after violence, we must first know who is culpable. Moreover, for theory building and explanatory purposes, we must be able to distinguish individual acts of violence committed as part of an organized campaign to further specific goals from unassociated deaths that happen concurrently to these insidious campaigns. For example, in 1982 Efraín Ríos Montt, a senior officer in the Guatemalan army, seized power in a coup - subsequently declaring himself president. When Montt came to power he waged one of the Western hemisphere's most brutal genocidal campaigns against Guatemala's indigenous Mayan and Ladino populations. ${ }^{201}$ According to the United Nation's Commission for Historical Clarification between 1960 and 1996 some 200,000 people were massacred or disappeared as a result of state-directed

${ }^{201}$ Guatemala: Memory of Silence, Report of the Commission for Historical Clarification, United Nations, (1997). 
terror. $^{202}$ More than 400 villages were destroyed and burned to the ground, with some regions experiencing between 70 and 90 percent of villages ruined. ${ }^{203}$ Though Montt was quickly deposed by his Defense Minister in 1983, he made a substantial impact on the course of Guatemala's civil war and genocide. ${ }^{204}$ Twenty years later, in 2003 Montt was blocked from partaking in the presidential election as a candidate by a judicial ruling. ${ }^{205} \mathrm{In}$ response to this court decision, Montt was instrumental in fomenting violent demonstrations in July. During these violent protests a journalist suffered a heart attack and consequently died "while being chased by a mob of FRG [Guatemalan Republican Front] supporters." ${ }^{\text {206 }}$ How do we characterize this particular death? Is Montt responsible for the death of this journalist? Should we consider Montt a perpetrator (in addition to his previous acts) because of his actions that instigated mob violence? This example illustrates the difficulties in categorizing specific violent episodes as part of a broader phenomenon. Distinguishing between violent episodes associated with mass political violence and deaths that transpire concurrently is an inherently difficult task. Counting direct and indirect fatalities attributable to perpetrators is an essential and often overlooked facet of mass political violence studies - particularly when a conflict results in tremendous numbers of

\footnotetext{
${ }^{202}$ Ibid, 17.

${ }^{203}$ Ibid, 40.

204 "Profile: Guatemala's Efrain Rios Montt," BBC News (May 11, 2013), accessed on November 8, 2017. URL: http://www.bbc.com/news/world-latin-america-22486387.

${ }^{205}$ Ellen L. Lutz and Caitlin Reiger, ed., Prosecuting Heads of State (New York: Cambridge University Press, 2009), 57.

${ }^{206}$ Ibid.
} 
deaths (e.g., the Holocaust or Rwanda). However, it is one endeavor we must pursue for the purpose of intellectual and historical accuracy.

The second question logically follows from the first: does an individual have to personally engage in violence against another to be labelled a perpetrator? Those who murder, rape, torture, or destroy property with intent to harm are indeed perpetrators. Nevertheless, those who perform these manual tasks are most likely low ranked soldiers or conscripts - frontline personnel responsible for implementing the wishes of superiors. Often leaders who direct their minions to commit violence in pursuit of ideological or otherwise motivated goals do not directly participate in the acts of violence themselves. And yet, the obvious answer here is that individuals who facilitate, organize, and direct violence without personally wielding instruments of violence themselves are equally responsible and should carry the label "perpetrator."

The central premise of my dissertation framework rests in differentiating "types" of perpetrators. I use the word "type" in reference to classifying the collective social composition of perpetrators in a given episode. The types are identified by the relationship of the perpetrators to state authorities? For example, the Cambodian genocide/mass political violence perpetrators represent one archetype. In April 1975, a small communist revolutionary group - the Khmer Rouge - emerged from the Cambodian countryside and marched on Phnom Penh, the capital. From the beginning of their campaign, soldiers, peasants, and conscripts led by Pol Pot engaged in murderous violence against all ethnoreligious-national groups that opposed the Maoist revolt. It was common for perpetrators to slaughter anyone seen exhibiting Western culture, including those who were wearing glasses or speaking a foreign language. Of the estimated 3.3 million victims, most perished 
from forced relocation from urban centers to rural communities, murder, torture, slave labor and illness including malnutrition. ${ }^{207}$ This type of mass political violence perpetrator includes the leaders of the Khmer Rouge - Pol Pot, Son Sen, Yun Yat, Thiounn Thioeunn, Ta Mok, and senior party leaders - their bureaucratic minions responsible for implementing Pol Pot's Maoist ideology, and of course the ground-level perpetrators and accomplices who engaged in widespread dispossession, torture, and murder of the Cambodian people.

In this instance, all of these persons from the top of the governing pyramid to the lowly murderous soldier are considered perpetrators under my framework. Figure 3.1 visually represents the distinctions between each perpetrator complicit in the act of violence. In all mass political violence episodes there is a hierarchical structure of perpetrators. At the top of the order resides the leaders and organizers of violence. These are the Hitlers, Stalins, and Pol Pots of the world. Their vision and ideology form the basis for generating violence on a large-scale. Immediately below these leaders are what Richard Olson terms "managers." 208 This second tier is critical to the organizational structure of perpetrators. Managers are bureaucrats. They relay orders and directives of the leaders to the masses. Managers are a key link in the command structure between senior leadership and principal perpetrators on the frontline. Following managers are what most observers see when they examine violence - what I term "principal perpetrators". These individuals are the frontline personnel responsible for carrying out the directives of violence. Often these are the "notorious murderers" who reign terror upon victims. Though they are most

\footnotetext{
207 Patrick Heuveline. 'Between One and Three Million': Towards the Demographic Reconstruction of a Decade of Cambodian History (1970-79)" Population Studies (Taylor \& Francis, 1998) pp. 49-65; Craig Etcheson. After the Killing Fields: Lessons from the Cambodian Genocide, Greenwood (2005).

${ }^{208}$ Richard Olson, personal correspondence with author, November 8, 2017.
} 
influential in the process of violence, principal perpetrators may not comprise the bulk of the command structure. In order for perpetrators to possess the means of violence they must be supported by what I refer to as "accomplices." These persons can be willing supporters of the regime or conscripts forced to provide logistical, communication, or transportation support. The prime difference between principal perpetrators and accomplices is that the former may engage in all activities from direct violence to logistical support, while the latter does not directly engage in the act of violence against a target group. They support frontline soldiers in their war against "opponents."

Taken together, perpetrators of mass political violence include leaders, managers, principal perpetrators, and accomplices. All four categories of persons are complicit, in some manner, in the collective act of violence. There is a fifth category that straddles the line between perpetrator and bystander. This includes the beneficiaries of violence. Beneficiaries are those who do not directly provide support to perpetrators in their pursuit of violence but have personally benefited from perpetrator actions. For instance, during the Holocaust many ordinary Germans financially benefited from the destruction of Jewish businesses and their loss of personal property. These individuals were beneficiaries of the dispossession of Jewish property but many had no influence in the enactment of these policies; though many supported them. In Figure 3.1 I place beneficiaries on the border of perpetrators - sometimes included and other times excluded. The reason for this variable approach to beneficiaries is that some individuals and, by extrapolation, the companies they ran, profited from the Holocaust. Stuart Kreindler writes, "thus far, the companies that have been sued [on behalf of former employees who claim they were forced to work without pay] include Volkswagen AG, Siemens AG, Bayersiche Motoren Werke AG, 
Daimler Benz AG, Leica Camera AG and I.G. Farben AG." ${ }^{209}$ How do we characterize Volkswagen or Hugo Boss - a Nazi uniform manufacturer? ${ }^{210}$ It would seem Hugo Boss financially benefited from the Nazi regime while, not directly from the mass murder of millions. Other beneficiaries may not have received any financial gain but benefitted socially. An individual may be promoted over a peer because of their affiliation with socalled "undesirables" groups in society. This category is multifaceted and can be highly fluid, which is why it straddles the periphery of perpetrator and non-perpetrator categories.

\section{Figure 3.1}

\section{Hierarchy of Perpetrators}

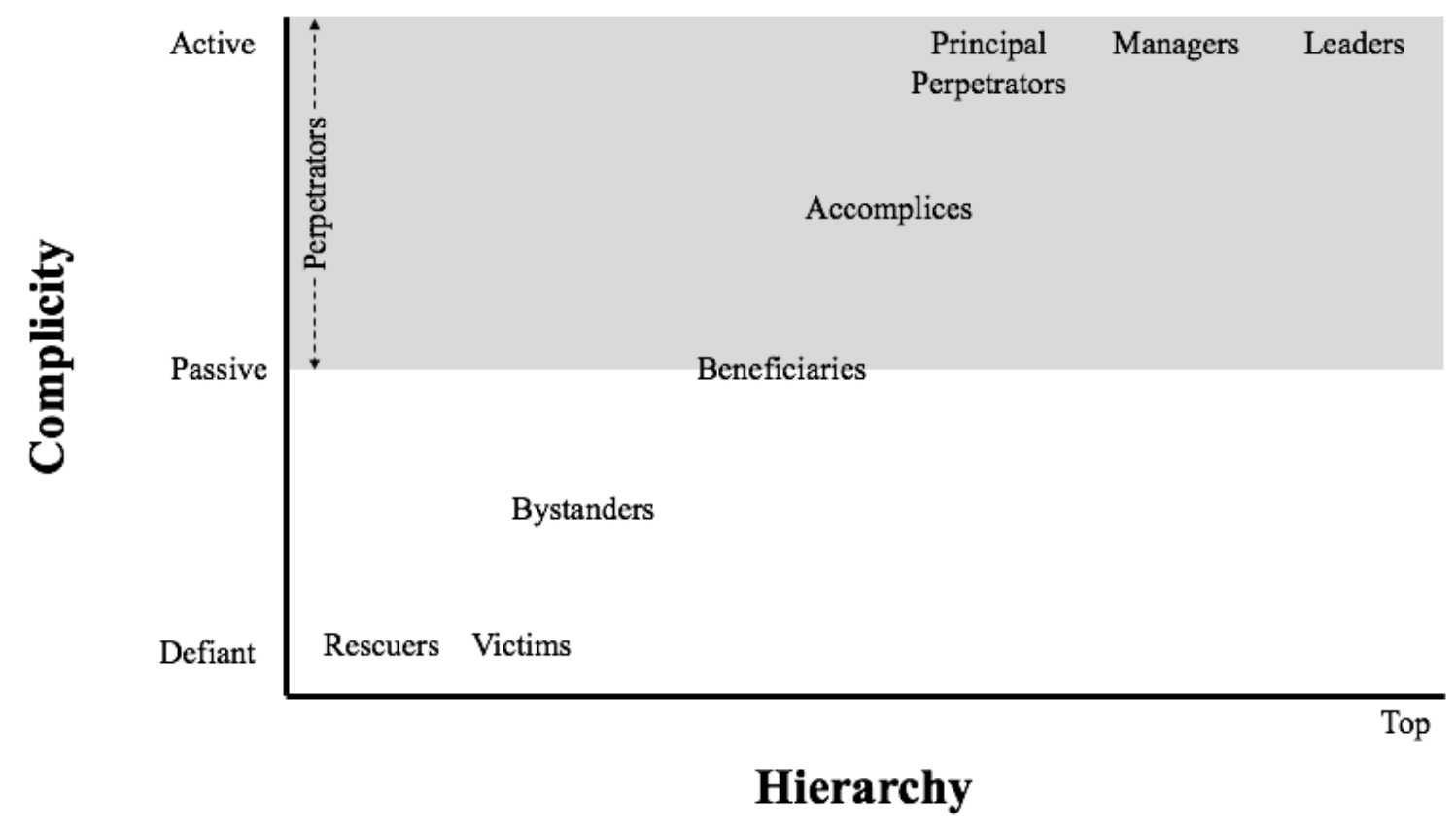

${ }^{209}$ Stuart M. Kreindler, "History’s Accounting: Liability Issues Surrounding German Companies for the Use of Slave Labor by Their Corporate Forefathers," Penn State International Law Review 18:2 (2000), p. 344.

210 The Associated Press, "Hugo Boss Acknowledges Link to Nazi Regime," The New York Times online, August 15, 1997. URL: http://www.nytimes.com/1997/08/15/business/hugo-boss-acknowledges-link-tonazi-regime.html. 
Finally, Figure 3.1 lists three other classifications: bystanders, victims, and rescuers. Bystander is a generic term, referring to any person who does not participate in the process of violence. They ignore, neglect, remain passive or might be unaware of ongoing events. Furthermore, I distinguish bystanders from beneficiaries, as the former do not receive any gain from the events of the day. Victims are easily identified as those targeted by perpetrators irrespective of motivation. The final category worth noting is "rescuers." This group may be domestic actors who form collective security organizations or rebel groups that fight back against perpetrators. Or, they may take the form of international peacekeeping missions sent to stop, ameliorate, or prevent the spread of violence. The important distinction here is that these individuals could be domestic or internationally constituted or a mix.

\section{Four Modes of Mass Political Violence}

My research identifies four major types of perpetrators of mass political violence:

(a) state actors, (b) state-society coalitions, (c) state-sponsored groups, and (d) non-state actors. Each type of perpetrator is conceptually and empirically distinct. Moreover, each category is most likely to emerge under specific state-society conditions. Unlike previous authors who investigate "why" perpetrators maim, torture, and kill victims en masse. I ask, "How" perpetrators sustain violence over time. To some extent, the "why" question can be case-specific. For instance, why regimes murder dissidents or expel ethnic groups from their territory is a question fundamentally about motivations of both leaders and societies. Motives can emerge from broad ideological goals or they may come from narrow personal grievances. What I am concerned with is, chiefly, how perpetrators garner the capacity and 
capability to enact violence on a large-scale, irrespective of their particular motives or those of their leaders. I contend that individuals may choose violence over alternative options for any number of reasons, or for simply no reason at all. Unpacking the political psychology of perpetrators is ultimately impossible. Therefore, my research examines the state-society relations and institutional structures that enable perpetrators to emerge with the intent to physically execute extreme violence. Understanding these enablers of violence allows for a better understanding of how perpetrators enact their destruction on targeted groups.

What makes each category of perpetrator unique? To start, the level of government support varies by category, as does the level of social participation. Each category is most likely to occur under three specific state-society conditions. First is regime power, which is a function of public and private sector support of senior political and military leaders in a state. Membership within the regime requires unbridled loyalty to the chief executive and his/her senior advisors. The larger regime membership is; the greater regime power may be over time. Second, is state capacity. My definition of state capacity is derived from McAdam et al.'s 2001 work Dynamics of Contention, in which they contend that state capacity is "the degree of control that state agents exercise over persons, activities, and resources within their government's territorial jurisdiction. ${ }^{211}$ Third, a society's appetite for violence is the extent to which the regime and perpetrators can depend on individuals in society to participate in the perpetration of mass political violence. Societies may be docile, cooperative, supportive, or apathetic to violence. In all of these cases, perpetrators make assessments of society to determine their level of support and act accordingly.

211 McAdam, Doug, Sidney Tarrow, and Charles Tilly. 2001. Dynamics of Contention. Cambridge: Cambridge University Press, p. 78. 
Table 3.2 details each of the three specific conditions each category of perpetrator requires for them to engage in mass political violence. Each category is conceptually and empirically distinct from the others. Not only are they distinct types of perpetrators, but they have not empirically occurred at the same rates throughout the $20^{\text {th }}$ and $21^{\text {st }}$ centuries. State actors and state-society coalitions have been by far the two dominant modes of perpetrators since the early 1900s. More recently, state-sponsored groups and non-state actors have become increasingly more relevant and advantageous to those seeking power, control, or independence. What follows is a summary of each perpetrator category and associated characteristics. 
Table 3.2: Perpetrator Ideal Types (Modes) and Defining Characteristics

\begin{tabular}{|c|c|c|c|c|}
\hline Characteristic & State & State-Society Coalition & State-Sponsored Groups & Non-State Actors \\
\hline Perpetrators & $\begin{array}{l}\text { Government agents, } \\
\text { bureaucrats, institutions, } \\
\text { and regime hardliners are } \\
\text { the primary perpetrators of } \\
\text { violence; in some cases, } \\
\text { individual opportunism and } \\
\text { bandwagoning exists at a } \\
\text { local, non-systematic level, } \\
\text { that is concurrent to } \\
\text { governmental actions }\end{array}$ & $\begin{array}{l}\text { Government and } \\
\text { organized social units } \\
\text { are explicit partners in } \\
\text { the implementation of } \\
\text { violence, neither } \\
\text { possesses a clear } \\
\text { command and control } \\
\text { over its counterpart, } \\
\text { they work in } \\
\text { conjunction towards a } \\
\text { common goal/enemy }\end{array}$ & $\begin{array}{l}\text { Government lacks } \\
\text { resources, will or } \\
\text { determination to } \\
\text { implement violence on its } \\
\text { own; it coordinates non- } \\
\text { state or sub-state actors to } \\
\text { kill on its behalf; } \\
\text { government may } \\
\text { participate in a supportive } \\
\text { or clandestine role in } \\
\text { executing violence }\end{array}$ & $\begin{array}{l}\text { No government } \\
\text { involvement; all } \\
\text { violence is carried out } \\
\text { by an independent non- } \\
\text { state actor that } \\
\text { mobilizes and } \\
\text { coordinates amongst } \\
\text { itself; perhaps with } \\
\text { coercive or voluntary } \\
\text { methods of maintaining } \\
\text { social support }\end{array}$ \\
\hline $\begin{array}{l}\text { Regime Power } \\
\text { (Condition 1) }\end{array}$ & $\begin{array}{l}H I G H \text { : Hierarchical regime } \\
\text { with strong, charismatic } \\
\text { leader, able to wield } \\
\text { personal political power } \\
\text { outside bureaucracy (e.g., } \\
\text { commands personal } \\
\text { loyalties) and inside } \\
\text { bureaucracy via rule } \\
\text { enforcement and creation; } \\
\text { regime maintains a } \\
\text { monopoly on the use of } \\
\text { force }\end{array}$ & $\begin{array}{l}\text { HIGH: Hierarchical } \\
\text { regime with strong, } \\
\text { charismatic leader, able } \\
\text { to wield personal } \\
\text { political power outside } \\
\text { bureaucracy (e.g., } \\
\text { commands personal } \\
\text { loyalties) and inside } \\
\text { bureaucracy via rule } \\
\text { enforcement and } \\
\text { creation; shares a } \\
\text { monopoly of the use of } \\
\text { force with independent } \\
\text { organized social units }\end{array}$ & $\begin{array}{l}\text { MODERATE: Powerful } \\
\text { regime with strong, } \\
\text { decisive leader, controls } \\
\text { formal and informal } \\
\text { institutions; lacks } \\
\text { resources to fully } \\
\text { implement strategy; relies } \\
\text { on coercive and co-opted } \\
\text { support from organized } \\
\text { social groups to maintain } \\
\text { power and influence; lacks } \\
\text { a monopoly on the use of } \\
\text { force }\end{array}$ & $\begin{array}{l}L O W \text { : Regime lacks } \\
\text { political power and } \\
\text { influence, control often } \\
\text { limited to capital and/or } \\
\text { essential installations } \\
\text { within territory; regime } \\
\text { confronted with } \\
\text { competition from } \\
\text { below; lacks a } \\
\text { monopoly on the use of } \\
\text { force }\end{array}$ \\
\hline
\end{tabular}


State Capacity ${ }^{\mathrm{a}}$

(Condition 2)

for Violence ${ }^{b}$

(Condition 3)
$H I G H$ : Strong degree of control over persons, activities, and resources within the territory

\section{$L O W$ :}

The median resident is not supportive of participating in killing of target group; low appetite for direct involvement in violence

HIGH ABILITY: to organize, implement, and sustain killing overtime with use of state bureaucratic structures without external intervention
HIGH: Strong degree of control over persons, activities, and resources within the territory

\section{$H I G H$}

(COOPERATIVE):

Organized social units emerge from society that embraces dehumanization of target group and encourages participation in violence

\section{HIGH ABILITY: to} organize, implement and sustain killing overtime with use of state bureaucratic structures without external intervention; often targets an ethno-cultural minority group
$L O W$ : Weak degree of control over persons, activities, and resources within the territory, often lacks complete control over territory

\section{$H I G H$}

(SUPPORTIVE):

Organized social units emerge from society that embrace government led targeting and encourages participation in violence

MODERATE ABILITY: to organize, implement and sustain killing overtime; often time bound by order of regime
$L O W$ : Weak degree of control over persons, activities, and resources within the territory, often lacks complete control over territory

\section{LOW}

(ISOLATED POCKETS):

Localized support for non-state actor and participation in violence; often coerces support from below

\section{LOW ABILITY: to} organize, implement and sustain killing overtime, often temporal and geographically constrained

Notes:

${ }^{a}$ Definition of state capacity is derived from McAdam, Doug, Sidney Tarrow, and Charles Tilly. 2001. Dynamics of Contention. Cambridge: Cambridge University Press, p. 78. State capacity the "degree of control that state agents exercise over persons, activities, and resources within their government's territorial jurisdiction."

${ }^{\mathrm{b}}$ Social appetite for violence (SAV) is similar to a society's national mood/desire towards participation in violence against a target group. 


\section{$\underline{\text { State Actors }}$}

State actors, or their time-period equivalents, have long been considered the usual suspects in the perpetration of mass political violence. In the modern era, government agents, bureaucrats, institutions, and regime hardliners are the primary culprits of violence. When states choose to enact violence as public policy, the results are often most devastating. For example, the Soviet Union under Josef Stalin fomented the 1932-33 Ukrainian "great famine," which is recognized to have claimed more than 6 million lives. ${ }^{212}$ The great famine of 1932-33 was unlike its predecessor of 1921-22; in this case, the state induced famine was brought about by Bolshevik leaders in response to early Ukrainian nationalist sentiments. In pursuit of maintaining the Soviet Union's grip over the breadbasket of Europe, Soviet collectivization policies forced Ukrainian peasants to produce tons of crops for consumption outside their borders. Here, the state enacted public policies and indirectly murdered millions to maintain political power over their territorial claims of Eastern Europe. When states choose to pursue such a path toward mass political violence, for whatever reasons, the results have shown to be most deadly of any perpetrator category.

For states to opt for mass political violence, specifically violence that reaches a threshold of 10,000 victims within a 12-month span, certain state-society conditions must be in place prior to the commission of violence. Here, I discuss each specific structural factor: regime power, state capacity and a society's appetite for violence. First, "regime power:" when assessing perpetrator strength and ability to commit extreme violence over

\footnotetext{
${ }^{212}$ Stephane Courtois et al., The Black Book of Communism: Crimes, Terror, Repression (Cambridge and London: Harvard University Press, 2004), p. 159.
} 
time, we must distinguish between the strength of a state (i.e., its ability to govern its territorial space) and the power wielded by hardliners within the state. For a state to sanction, support, enact, and commit mass political violence, the regime must have immense hierarchical power with a strong, often charismatic leader at the top, able to wield personal political power outside the bureaucracy (i.e., commands personal loyalties) and inside the bureaucracy via rule enforcement and creation. The regime must maintain a monopoly on the use of force within its territory and be unquestionably the sole domestic entity capable of enforcing "justice" as it deems appropriate.

These are "strong" states. They do not have to be rich or economically powerful states in the international system; but the institutions and regime in power must be strong and capable vis a vis society - capable of weathering domestic and international political storms and returning political fire when necessary. For example, the Soviet Union from Stalin to its collapse under Mikhail Gorbachev is a prime example of a state exhibiting high regime power. At various periods, particularly in the early $20^{\text {th }}$ century, the Soviet Union was not exceptionally rich nor was it as economically developed as its Western counterparts. However, the regime maintained a strong sense of ownership and control over its peoples; never allowing for the opportunity of political rivals to emerge in any sufficient fashion.

A strong regime is the first and foremost condition for state actors to commit mass political violence. Nevertheless, there remain many strong regimes around the globe that have not pursued such policies despite some desire to do so. Herein lies our second structural factor: state capacity. Within political science and public administration, there are dozens of definitions (similar to my previous discussion of competing definitions of 
genocide) to delineate state capacity. Embedded in these descriptions are differences between a nation's bureaucratic and infrastructure state capacity. The differences here can be crucial to understanding how I operationalize this condition for the sole purpose of anticipating mass political violence onset. In my analysis of states at risk of violence, I am solely concerned with a nation's bureaucratic state capacity and to a lesser degree its infrastructural power. I adopt Doug McAdam, Sidney Tarrow and Charles Tilly's conceptualization of state capacity as "the degree of control that state agents exercise over persons, activities, and resources within their government's territorial jurisdiction." ${ }^{213}$ When perpetrators possess high state capacity, as delineated here, they are able to mobilize people and material across their territory irrespective of their level of economic development.

Perhaps the most notorious example of a perpetrator type exhibiting strong state capacity is when hardliner Hutus took control of the Rwandan state in 1994 The Rwandan genocide is an example of a state-society coalition perpetrator, however in both categories of perpetrators (i.e., state actors and state-society coalitions) high state capacity is a requisite. Unlike Rwanda's neighbors, the Habyarimana regime exhibited uncanny strength at regional and local levels throughout its sovereign territory. Rwanda was saddled with low economic development and poor infrastructural capacity at the time of the genocide. However, the regime and bureaucratic state capacity were remarkably strong for an underdeveloped economy. Regime hardliners were fully capable of mobilizing support across all provinces and communes for the purpose of implementing mass political

${ }^{213}$ McAdam et al., Dynamics of Contention, p. 78. 
violence against moderate Hutu political opponents and the Tutsi minority across the state. Here, hardliners and regime elements quickly mobilized support and executed countless pogroms, ambushes, house-to-house raids, executions, and roadblocks which turned into mobile killing centers within days of the genocide's start. Though the Rwandan genocide reflects a separate category of perpetrator, the specific condition of high state capacity is perhaps our best example to date.

Finally, for a state to target a substantial portion of the population, at least 10,000 persons, perpetrators must at some level assess society's response to violence. Not all societies will remain docile, cooperative, or supportive of such measures, particularly if members of the targeted group are capable of self-mobilization in response to violence. Here, state actors explicitly and implicitly assess the national mood in society. Are average workers, teachers, students, farmers, and the like going to passively stand by during the evolution of violence, or will they fight back? When there is a low social appetite for violence, meaning the median resident is not supportive of participating in the killing of the target group, they will largely become bystanders to mass political violence and offer little to no resistance. Taken together, when regime power is strong, bureaucratic state capacity is high, and the social mood is low for obstructing violence, state actors are more likely to emerge and enact mass political violence against any perceived target group that is deemed a rival to their strategic goals and objectives.

\section{State-Society Coalitions}

As mentioned, state actors have been one of two primary perpetrators of mass political violence throughout the $20^{\text {th }}$ and $21^{\text {st }}$ centuries. The other dominant perpetrator 
type in this regard has been what I refer to as state-society coalitions. This category of perpetrator is principally distinguished from the former by the role of organized social units as explicit partners in the implementation of violence. When state-society coalitions form and emerge to marginalize and destroy targeted groups, they do so in states with a strong regime, high level of state capacity, and a high degree of support from independent societal actors.

There are several reasons why state actors may form an explicit or implicit coalition with sub-state or non-state armed groups. First, a regime may not possess a clear monopoly on the use of force within its territory. In these cases, regime officials deem a rival group to be an obstacle to national goals or objectives. However, the regime may lack sufficient military capability to enact its designs on this target group. Therefore, in order to achieve their desired outcomes, state actors enter into an informal (though possibly formal) contract with non-state armed groups. This newly formed coalition possesses the financial and physical capacity to engage the targeted group in sustained violence over time. The 1994 Rwandan genocide is a prime example; the governing Hutu regime did not retain sufficient military prowess throughout the territory, and thus actively sought out the support of two militias groups which were seen to be very aggressive in hunting down Tutsi civilians during the genocide.

A second situation in which a state-society coalition is deemed effective for MPV results when the government maintains a monopoly on the use of force within its territory, but actively encourages vigilantism and extra-judicial killing squads to support its agenda. In addition to providing much needed resources to the cause of the regime, active vigilante mobs roaming the country side in search of "asocial" persons provide the regime with ample 
domestic political cover, plausible deniability of action, and an indirect measure of social support for mass political violence. The Holocaust and other Nazi genocidal atrocities during World War II are a particularly violent example of a state-society coalition's ability to target pariah groups en masse.

Similarly, a third reason this category of perpetrator is seductive to murderous governments is that this coalition is most likely to emerge against an ethno-religious minority group and not a substantial majority of the population. One reason the Holocaust was so comprehensive in its ability to enact violence across Nazi-occupied Europe is that its perpetrators had broad social support and a unifying anti-Semitic ideology to propagate Nazi racially-driven policies. Because non-state armed groups targeted ethno-religious minorities, there was little risk of these killing squads' and regime soldiers' goals colliding. In fact, they overlapped and buttressed one another's mission. Therefore, a state-society coalition has two separate parts that pragmatically function quasi-independently, but with a unified goal in mind.

Fourth, state-society coalitions cannot be conjured out of thin air. In order for this category of perpetrator to emerge and solidify its cooperation in advance of mass political violence, there must be a unifying ideology that brings together state actors and persons in society to form sufficiently capable non-state armed groups or militias. Absent any unifying belief system that forms the basis of cooperation between each wing of the coalition, perpetrators are unlikely to gain sufficient momentum in accomplishing widespread violence. In these cases, ideological support is crucial. However, once ideological support evolves, it may gain strength and energy of its own accord. Thereby sowing the seeds of vigilantism in the population. If states do not partner with non-state 
armed groups at this point, they may face opposition from society in pursuit of their goals. Under this fourth reason, state agents may have fueled the flames of violence with their ideology, thereby fanning the flames of hatred and forcing them into violent action against political rivals. If these feelings remain unchecked by the state, non-state armed groups could turn on the state. Therefore, aligning with such groups becomes paramount to the state in achieving its goals and objectives.

Finally, state-society coalitions are likely to gain strength during times of great political upheaval or rivalry. States that face intense interstate wars or intrastate armed conflict are likely to mobilize support among social actors. This mobilized support can be used in a coordinated fashion to target domestic minority groups while the armed forces and state actors direct the bulk of their efforts to addressing ongoing armed conflict. The Rwandan genocide is a case in point in which Hutu militiamen largely carried out the slaughter of moderate Hutus and the Tutsi minority concurrent with the military's campaign against the rebel Tutsi-led Rwandan Patriotic Front (RPF). Irrespective of the particular reason for the formation of a coalition to enact violence, state-society perpetrators are most likely to emerge in countries with a strong regime, strong state capacity to mobilize and control persons, activities, and resources within their territory, and a high degree of cooperation from organized social units often in the form of armed militias.

\section{State-Sponsored Groups}

Each prior category of perpetrator describes violent episodes in which the regime and state capacity maintain a strong degree of power, control and influence over domestic politics and a quasi-monopoly of violence. The final two categories of perpetrators are 
empirically less common in the $20^{\text {th }}$ and $21^{\text {st }}$ centuries, but have gained substantial momentum in recent years. One needs not look past the atrocities committed in the Eastern Democratic Republic of Congo, the Syrian Civil War, or in the Western jungles of Burma (Myanmar) where social groups labeled by the state and government officials sanction mob violence, looting, slash-and-burn tactics, and intense vigilantism that has resulted in thousands of Rohingya Muslim deaths and tens of thousands more internally displaced and refugees.

First, state-sponsored groups as perpetrators of mass political violence, particularly episodes where at minimum 10,000 victims perished, are indicative of a government that lacks resources and the will or determination to implement violence on its own. This category reflects a regime that possess a high level of regime power but low state capacity. In these instances, governments employ third-party organizations such as non-state actors, sub-state actors, non-state armed groups, or armed militias to kill on its behalf. Because the government maintains strong regime power but suffers low state capacity, it may occupy a supportive or clandestine role in the execution of violence, but does not possess sufficient capabilities to directly confront its political rivals in total.

The chief difference between state-sponsored groups as perpetrators of mass political violence and state actors as the sole offender lies in a society's collective atmosphere. State-sponsored groups are most likely to materialize when the regime is strong, state capacity is weak, but society retains high and supportive appetites for committing violence (on behalf of the regime). In addition to feasibility, the clandestine nature of seeking third-party perpetrators has particularly become advantageous in the era of great human rights awareness. Plausible deniability and outright denials of offenses 
committed during armed conflict has become increasingly a popular tactic used by perpetrators of mass political violence. In fact, denials of genocide have been furthered in no small part by the example given in the Turkish government's vehement denials of the Armenian genocide under its predecessor ruling regime, the Ottoman Empire. In Turkey's case, denial is less about particular violent events, though this is a central tenet to its unfounded claims, but is more about the allure of maintaining international prestige and honor. Therefore, I expect this category of perpetrator to become increasingly more strategic for strong regimes seeking to remain in the shadows of anonymity moving forward.

Where might we see state-sponsored groups commit mass political violence? Typically, state-sponsored groups are most likely to emerge in fragile and weak states experiencing armed conflict or political upheaval - especially states where the government has limited to no ability to govern all territorial provinces under its sovereign control. For example, the on-going armed conflict in eastern Democratic Republic of Congo is one example of a violent episode involving state-sponsored groups who have perpetrated mass political violence. The non-state armed group M23 is a prime example of a state-sponsored group waging war and violence in the nearly uncontrolled territory of eastern Congo. In this instance, M23's state benefactors sought anonymity and deniability of this support in exchange for financial and material resources discovered during the evolution of violence in Congo. Chapter six of this dissertation unpacks in greater detail this newly formed category of mass political violence perpetrator. To date, state-sponsored groups remains relatively uncommon, particularly in the sense that they are capable of reaching a 10,000 victim threshold within a 12-month time period. That said, as the technologies perpetually 
change and social movements continue to upend autocratic regimes globally, it is more likely we will see this category of perpetrator increase in occurrence over the coming decades to the detriment of human security and international peace.

\section{Non-State Actors}

Often overlooked by Genocide Studies scholars are the progressively violent capabilities of non-state actors to enact, perform, execute, and deliver mass political violence against targeted groups in the modern era. Most theories of mass violence have neglected studying the effects and causes of non-state actor violence in the evolution of large-scale violence. Here, I correct this omission and under-theorizing of these particularly vicious and brutal agents. This category of perpetrator is most likely to emerge in weak, failing, and failed states. The perpetrators enjoy no government involvement. All violence is carried out by an independent non-state actor that mobilizes and coordinates amongst itself with a potential limited degree of society support within its governable territory. The limited nature of societal support may be from coercive or voluntary methods. In the case of Boko Haram in Northern Nigeria, the non-state actor regularly utilizes coercive measures in forcing the local population to support its efforts at self-governance and sustainability. It is likely that non-state perpetrators of mass political violence may be large rebel movements or ad-hoc militias, organizations with the ability to sustain an organizational structure overtime. Nevertheless, these relatively new perpetrators of mass political violence are increasingly gathering more capabilities and territorial opportunities to enact violence as the number of weak and failing states persists across the globe. Chapter six will discuss this paramount problem further. 


\section{Conclusion}

This chapter constitutes the basis of my framework for understanding the causes and consequences of mass political violence. Much progress has been achieved over the course of the past eight decades. Notwithstanding the seminal works of many in our field, much has yet to be unmasked about the nature of perpetrators and under what conditions they materialize to commit, enact, prescribe, coerce, mastermind, or otherwise engage in perhaps humanity's most abominable crime. Perchance an even more appalling discovery would be the understanding that in any given country, state, or context society and its many factions could be mere steps away from enduring such heinous crimes that befell our mortal forebears.

I did not intend at the outset of my doctoral studies to explicitly write this dissertation on the perpetrators of mass political violence and genocide. Perhaps Judith Herman writes it best, "When...traumatic events are of human design, those who bear witness are caught in the conflict between victim and perpetrator." ${ }^{214}$ When confronted with a choice between victims and perpetrators, morality, ethics, and common decency dictate we take sides with those experiencing persecution. As discussed in chapter two, the field of Genocide Studies cannot escape this scholar-activist dynamic. If we are truly going to understanding the causes of mass political violence and genocide, we must examine, in detail, those who wish to perpetrate such crimes. It is only with intense studies of these perpetrators that academics and policymakers can hope to mitigate such conflicts in the

\footnotetext{
${ }^{214}$ Judith Herman, Trauma and Recovery: The aftermath of violence - from domestic abuse to political terror (New York: Basic Books, 1997), p. 7.
} 
future. I believe, that focusing our attention on the conditions that give rise to mass political violence perpetrators is the most effective means of achieving long-term understanding and ultimately prevention of such heinous acts. 


\section{CHAPTER IV:}

\section{STATE ACTORS AND MASS POLITICAL VIOLENCE}

“...it is not by speeches and majority resolutions that the great questions of the time are decided... but by iron and blood."

- Prussian Prime Minister Otto von Bismarck, $1862^{215}$

"On the one hand, tyranny and barbarism are seen as a reversal of progress and rationalization. On the other hand, they were seen as the very culmination of rationality and modernity."

- Abram de Swaan, 2001 216

"If massacre proceeds first and foremost from a mental process, it is clearly a priority to examine the "intellectual framework" that provides meaning to mass violence before it occurs."

- Jacques Semelin, $2007^{217}$

${ }^{215}$ Excerpt from Otto von Bismarck's "Blood and Iron" speech at a meeting of the Prussian Parliament on September 30, 1862. Translated by Jeremiah Riemer from source: Otto von Bismarck, Reden 18471869 [Speeches, 1847-1869], ed., Wilhelm Schüßler, vol. 10, Bismarck: Die gesammelten Werke [Bismarck: Collected Works], ed. Hermann von Petersdorff. Berlin: Otto Stolberg, 1924-35, pp. 139-40. URL: http://germanhistorydocs.ghi-dc.org/sub_document.cfm?document_id=250\&language=english.

${ }^{216}$ Abram de Swaan, "Dyscivilization, Mass Extermination and the State," Theory, Culture \& Society Vol. 18:2-3 (2001), p. 265.

${ }^{217}$ Jacques Semelin, Purify and Destroy: The Political Uses of Massacre and Genocide. Translated from the French by Cynthia Schoch, (New York: Columbia University Press, 2007), 54. 


\section{Introduction}

States or their time period equivalents - villages, fiefdoms, municipalities, principalities, city-states, kingdoms, or empires - have been responsible for some of humanity's most odious atrocities: genocide and mass political violence (MPV). Political scientists commonly trace the "contemporary international system" back 370 years to the treaty of Westphalia in $1648 .{ }^{218}$ However, governments, their time period equivalents, or organized social groups have waged "war" against civilian populaces for millennia. Examples of genocide and genocidal language can be read in some of our most sacred religious texts that we often turn to for guidance and comfort in our moments of desideratum. Although the Christian bible cannot be viewed as "historically precise," it can elucidate the prevailing military tactics of antiquity. According to the book of Exodus, God said, "I have indeed seen the misery of my people in Egypt. I have heard them crying out because of their slave drivers... so I have come down to rescue them... [and bring them to] a good and spacious land, a land flowing in milk and honey" [3:7-8]. Subsequently, in the book of Deuteronomy, God stated, “...of the cities and these people, which the Lord thy God doth give, thee for an inheritance, thou shalt save alive nothing that breatheth" [20:15-16]. Finally, read the book of Samuel in which the Lord instructs Samuel to "...go and smite Amalek, and utterly destroy all that they have, and spare them not; but slay both man and woman, infant and suckling, ox and sheep, camel and ass" [15:3]. However unfortunate these passages are for the victims, they are but a small

\footnotetext{
218 Barry Buzan and Richard Little, "International systems in world history: remaking the study of international relations," in Stephen Hobden and John M. Hobson eds., Historical Sociology of International Relations (Cambridge: Cambridge University Press, 2002), p. 200.
} 
window into human history's tortured path that includes mass political violence and genocide enacted by various forms of governments or their paramilitaries groups.

As rhetorically demonstrated, mass political violence is not a new phenomenon. Perhaps, MPV episodes of the last two centuries have been more intensely traumatic and trial-tested then their comparable events in antiquity; but they are simply new takes on an old scourge. The increasingly violent nature of MPV perpetrators in the modern era can in some part be attributed to the maturation of society. Within social science spheres first in sociology and later picked up by political science - two opposing camps exist in a heated debate over the role of development and modernity's relationship to mass death in the $20^{\text {th }}$ and $21^{\text {st }}$ centuries. This is not the appropriate venue to analyze each theoretical explanation at length, as there is not sufficient time nor space in this chapter to delve into each camp's minute arguments. In lieu of a detailed analysis, here I offer a summary of their positions for instructive purposes in situating MPV today.

The first faction emerged in the late 1930s with Norbert Elias's publication The Civilizing Process. Elias's work was originally published in German in 1939 and largely remained obscure to social scientists until its eventual translation into English in 1978. Elias was forced into exile by the rise to power of Adolf Hitler early in his career. ${ }^{219}$ Elias's thesis is that state formation through what he termed the "monopoly mechanism" - i.e., the enlargement and centralization of the administration state around the monopolization of violence and the control of taxation - foments a more "'civilized" relationship between individuals resulting in a reduction of all forms of violent behavior,

${ }^{219}$ Stephen Mennell, "Norbert Elias 91897-1990)," Norbert Elias Foundation. Accessed on February 5, 2018. URL: http://www.norberteliasfoundation.nl/elias/index.php. 
including state-instigated violence." ${ }^{220}$ Elias and his faction view the Holocaust (and by extension all state-instigated mass political violence) as an unfortunate side effect of the civilizing process. In their view, the breakdown of the civilizing process can occur for a variety of reasons, predominantly during: a) economic or political declines; b) the radicalization and mobilization of extreme elements in society that empower "fatherfigures" to embody the nation's conscience and give rise to domestic power politics and the scapegoating of marginalized communities for the nation's ill-gotten circumstances; or c) the "lust for submission" on the part of the masses to "father-figures" and extreme elements that manifest in times of great crisis or what we often term today as during the rise of Caudillos or Big Men in politics. ${ }^{221}$ Elias and his supporters view this return to savagery as an unfortunate mitigating effect of the civilizing process not indicative of modernity or the developmental process but resulting from case specific circumstances.

Contrary to Elias, Zygmunt Bauman, a renowned sociologist in his own right, was born into a secular Jewish family in Poland in $1925 .^{222}$ In his most famous work, Modernity and the Holocaust, Bauman argues that, "We suspect (even if we refuse to admit it) that the Holocaust could merely have uncovered another face of the same modern society whose other, more familiar, face we so admire..."223 For Bauman, the Holocaust (and by extension many mass political violence episodes of the modern age)

\footnotetext{
${ }^{220}$ Semelin, Purify and Destroy, p. 52.

${ }^{221}$ Jonathan Fletcher, Violence and Organization: An Introduction to the Work of Norbert Elias (Cambridge: Polity Press, 1997), p. 153-157.

${ }^{222}$ Paul R. Bartrop and Steven Leonard Jacobs, Fifty Key Thinkers on the Holocaust and Genocide (London and New York: Routledge, 2011), p. 45.

${ }^{223}$ Zygmunt Bauman, Modernity and the Holocaust (Maldon, MA: Polity Press, 2007 [1989]), p. 7.
} 
occur in "civilized" societies. In the example of Nazi Germany, "...culture and art had attained the height of refinement and intelligence, and where - what is more - the integrations of Jews had progressed furthest, that their fate of extermination would be sealed." ${ }^{224}$ Bauman and his supporters contend MPV is not an unfortunate side effect of modernity that is reached by mitigating factors. In fact, the manifestation of MPV and genocide in modern societies is a result of their progress toward bureaucratization and advancements in technology. ${ }^{225}$ It is because of modernity, Bauman argues that the Holocaust was so severe under the Third Reich.

You might ask, "how is this possible?" in a modern society that values the concealing of violence from public view and has yet to shed what Hannah Arendt terms "the animal pity by which all normal men [and women] are affected in the presence of physical suffering." ${ }^{226}$ Contemporary theorists argue that three conditions enable "normal" individuals to overcome their moral codes and participate in bloodthirsty killings. First, compartmentalization of violence from otherwise a pacified society. ${ }^{227}$ Once the intended victims, often marginalized communities used as scapegoats for the nation's problems are identified and perpetrators have been selected for the impending butchering, the target group is "screened off from the uninitiated so that the torturing and killing may proceed unnoticed..."228 Abram de Swaan refers to this compartmentalization

\footnotetext{
${ }^{224}$ Semelin, Purify and Destroy, p. 52-53.

${ }^{225}$ Ibid.

${ }^{226}$ Hannah Arendt, Eichmann in Jerusalem: A Report on the Banality of Evil (New York: Viking Press, 1964), p. 106.

${ }^{227}$ Swaan, "Dyscivilization, Mass Extermination and the State," p. 268.

${ }^{228}$ Ibid.
} 
of violence away from Main Street and forced into the shadows of society as the "bureaucratization of barbarism."229 This compartmentalization enables society writ large to maintain its passivity, thus abiding by the "civilizing process" while perpetrators exterminate "undesirables."

The second condition is the dehumanization of persons. Many scholars of violent conflict have studied the consequences of dehumanization and its importance in empowering perpetrators to murder members of a target population. ${ }^{230}$ Dehumanizing one's opponents to that of sub-human, possessing animalistic or even insect-like qualities is “the central construct in our understanding of man's [and woman's] inhumanity to man [and women]. ${ }^{\text {231 }}$ According to Philip Zimbardo, a preeminent psychologist responsible for the infamous Stanford Prison Study writes, "A Japanese general reported that it had been easy for his soldiers to brutally massacre Chinese civilians during Japan's preWorld War II invasion of China, 'because we thought of them as things, not people like us." 232 Essentializing the enemy as inherently inferior to the perpetrators' race, group, or creed allows for the characterization that all members of this group are inferior and thus exterminating them is almost an act of mercy rather than murder. This perverse

\footnotetext{
${ }^{229}$ Ibid.

${ }^{230}$ Philip Zimbardo, The Lucifer Effect: Understanding How Good People Turn Evil (New York: Random House Trade Paperbacks, 2008); Gregory Stanton, "The 8 Stages of Genocide," Genocide Watch: The International Campaign to End Genocide; Daniel Chirot and Clark McCauley, Why Not Kill Them All? The Logic and Prevention of Mass Political Murder (Princeton and Oxford: Princeton University Press, 2006); Ervin Staub, The Roots of Evil: The Origins of Genocide and Other Group Violence (Cambridge: Cambridge University Press, 1989); James Waller, Becoming Evil: How Ordinary People Can Commit Genocide and Mass Killing (New York: Oxford University Press, 2002).

${ }^{231}$ Zimbardo, The Lucifer Effect, p. 307.

${ }^{232}$ Ibid.
} 
rationalization of perpetrator actions has been recorded as a motivating factor in facilitating perpetrator's acts of violence (c.f., the Holocaust, Rwandan, Cambodian, Armenian, or Sudanese/Darfur genocides).

The final condition is the routinization of violence. Bauman refers to this as the "social production of killers" where "murder...masquerades as a routine and [an] unemotional function of orderly society." ${ }^{233}$ When the state and its agents legitimize killing, thereby bureaucratizing the process from mobile killing units to assembly lines of mass death, perpetrators are able to disconnect their moral compasses from each roboticlike act of violence. The routinization of violence has a twofold effect. First, it numbs the perpetrator's senses and dulls his/her emotional response to each murder. Rather than viewing each victim as a separate, unique murder, the perpetrator is able to disassociate the humanity of his/her victim to that of simply another widget in the assembly line of mass death. Second, because killing is ordered by the perpetrator's superiors, there is a rationalization that "I have been ordered to do this; those being killed are doing something wrong; they stand in my way; they deserve it; they are a threat to my own people; they are not quite human; [or] they are polluting [our way of life]" which further enables the routinization and thereby enhancing each perpetrator's proficiency in carrying out mass political violence. ${ }^{234}$

All of this is to articulate that in the modern era (circa 1900 forward for the purpose of this research agenda) mass political violence and genocide perpetrated by the state has increasingly relied on the levers of the administrative state and its bureaucratic

\footnotetext{
${ }^{233}$ Bauman, Modernity and the Holocaust, p. 245.

${ }^{234}$ Chirot and McCauley, Why Not Kill Them All? p. 56.
} 
forces to instigate widespread violence against targeted populations. In my analysis, Elias's assumption of the civilizing process to be of a linear nature, progressing toward a utopian end state is misguided. His analysis his useful in dissecting aspects of modernity, however, Bauman's thesis that the problem of MPV and genocide is related to society's drive toward development reflects, in my view, a more accurate reflection of events. Bauman's argument on modernity and the Holocaust forces us to grapple with the fact that for centuries states and their time period equivalents have engaged, instigated, perpetrated, funded, supported, and led campaigns of slaughter against opposing populations for a variety of reasons. Our history is scarred with the memories of such atrocities. The only difference today is that these perpetrators have the capability to bring their destruction to new heights by piggybacking off the levers of government.

The remainder of this chapter is divided into four sections. In the first section I describe the dynamic structural approach to understanding state-instigated mass political violence. In the second and third sections I apply this approach to the mass political violence in the Soviet Union and Cambodia. In the final section I conclude with a discussion of the variations between state-led mass political violence episodes.

\section{A Dynamic Structural Approach to State-Led Mass Political Violence}

As discussed at length in chapter three, understanding why (state) perpetrators ostracize, dehumanize, and murder target populations is inherently a difficult endeavor. Unpacking motives is a complex process. Therefore, rather than guessing at perpetrator motives, my framework examines conditions that give rise to mass political violence 
onset and its consequent duration. Understanding social structures before, during and after mass political violence is vital to grasping the nuances of this process of violence.

State perpetrators can emerge anytime and under nearly any circumstances. This does not mean they will be successful in achieving their goals and objectives, or in reaching the thresholds I discuss in chapter two for mass political violence. That said, they are often "first movers" in committing violence against target populations. Therefore, it is worth remembering that we must carefully distinguish once again between state perpetrators of "normal" political violence and those that reach mass political violence levels. The former is exceedingly more common than the latter; as such, we must not confuse the conditions that give rise between these different phenomena.

Figure 4.1 presents a model of the generic process of mass political violence. The circumstances within the existing polity structure that determine the emergence of perpetrators are threefold: regime power, state capacity, and a society's appetite for violence. State perpetrators continuously assess these slowly changing variables in order to grapple with possible rival groups, opportunity structures for success, or in assessing the strength of their own forces vis-a-vis the target group(s). When regime power is high, state capacity is strong and there is a low social appetite for violence - either in participating or obstructing state perpetrators - the state-society relations are most conducive to the emergence of state perpetrators for mass political violence. ${ }^{235}$

\footnotetext{
${ }^{235}$ See Table 3.2 for a comprehensive review of these variables.
} 


\section{Figure 4.1}

\section{A Model of the Generic Process of Mass Political Violence}

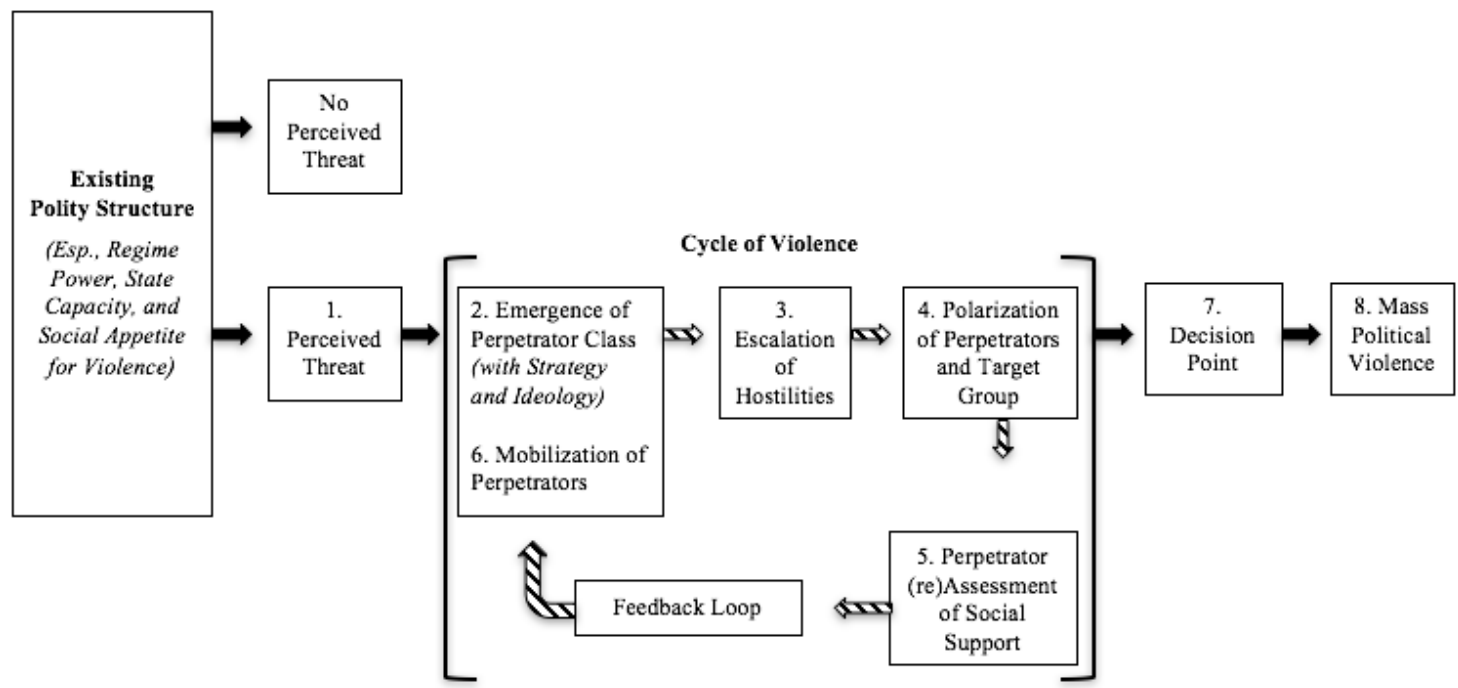

The emphasis on requisite conditions for perpetrator emergence is essential, but requisite conditions and perpetrator commencement are two entirely distinct matters. There are many societies in the world where these three conditions align but no perpetrators of mass political violence have emerged. Therefore, in addition to the requisite conditions, what factors explain mass political violence onset? I argue that perpetrators begin this process when they perceive a threat from some aspect of society that is perceived to challenge perpetrator goals and objectives. It is critical to note, that a "perceived" threat does not have to be based in reality or objectively measured. As long as the state perpetrators believe a target group qualifies as a "real" perceived threat to their goals or objectives they may embark on the process of violence (see Figure 4.1) that eventually ends in mass political violence. There are numerous examples in history where the state's goals did not align with a portion of its population and as such state perpetrators moved to quell, marginalized, or eliminate these groups. In each of these 
examples state perpetrators did not embark on policies designed to eliminate groups for the sake of killing. To the contrary, these governmental organs would have preferred each population abide by government's wishes and lay down whatever objections they held. Violence was first and foremost instrumental in nature and primarily was not the product of sadistic motivations.

In the beginning of 1921, the Bolshevik faction of the Russian Civil War was fast approaching victory against its enemies: The White army, the Cossacks, and had successfully routed Nestor Makhno's peasant anarchist movement. ${ }^{236}$ With victory in sight, the Bolsheviks turned to "pacification" strategies across the Soviet Union. One particularly brutal example can be traced to Tambov Province. ${ }^{237}$ In June 1921, the Politburo appointed General Mikhail Tukhachevsky to form an occupying force and "pacify" Tambov. ${ }^{238}$ Tukhachevsky's brutal tactics included hostage taking, extra-judicial killings, the construction of death camps where persons were gassed, and finally he ordered the mass deportations of individuals across the territory. ${ }^{239}$ Two months later on June $11^{\text {th }}$, Tukhachevsky and his co-conspirator Vladimir Antonov-Ovssenko, president of the Plenipotentiary Commission of the Central Executive Committee, co-signed Order No. 171. The order instructed personnel to, among other things, "Shoot on sight any citizen who refuse[s] to give their names," arrest or shoot residents of any village found

\footnotetext{
${ }^{236}$ Stephane Courtois, Nicolas Werth, Jean-Louis Panné, Andrzej Paczkowski, Karel Bartošek, and JeanLouis Margolin, eds., The Black Book of Communism: Crimes, Terror, Repression, trans. Jonathan Murphy and Mark Kramer (Cambridge: Harvard University Press, 1999), p. 108.

${ }^{237}$ Tambov Province is located approximately 300 miles ( 460 kilometers) southeast of Moscow.

${ }^{238}$ Ibid, p. 116.

${ }^{239}$ Ibid, p. 116.
} 
to be harboring weapons and munitions if discovered, “...Where arms are found, executive immediately the eldest son in the family," arrest or deport so-called "bandits" from Tambov province, confiscate bandit possessions and they instructed all personnel that "These orders are to be carried out rigorously and without mercy."240 After five weeks Order No. 171 was dissolved due to opposition at the highest-levels toward this “eradication” policy. Despite the order being withdrawn, military authorities and their minions continued their brutal assault. Just one snapshot of Tukhachevsky and AntonovOvssenko's reign of chaos can be found in the construction of seven concentration camps where the mortality rate of prisoners rose to $15-20$ percent a month by summer $1921 .^{241}$

The Tambov Province example demonstrates perpetrator tactics and their depths of brutality when confronted with a perceived threat; in this case a perceived insurrection and disobedience of residents in Tambov to the conquering Bolshevik regime. As the example shows, after a perceived threat is believed, step two in the process of mass political violence is the emergence of the perpetrator type - in this case state perpetrators - with a strategy and unifying ideology to confront the target group. After the perpetrators emerge as a fighting force, there is escalation in hostilities between the perpetrators and target group(s). This escalation is followed by a polarization between each faction. Likely in response to state orders, propaganda, discrimination or initial violence. At this point perpetrators re-assess social support for government, target group, and the general willingness of society to fight, flee, or standby.

\footnotetext{
${ }^{240}$ Ibid, p. 116-117.

${ }^{241}$ Ibid, p. 118.
} 
Steps two through five may occur in rapid succession or over a drawn out, protracted period of time. After perpetrators have re-assessed society's appetite for violence, and have explicitly or implicitly concluded that most of society will remain docile to their intentions, further mobilization of perpetrators takes place. For obvious reasons, there must have be at the very least initial mobilization efforts prior to step six in this process. Step six merely reflects an acceleration in this previously established effort and is a pseudo-formalization of perpetrator efforts at mobilization or recruitment.

As mentioned, the cycle of violence (see Figure 4.1) may transpire over the course of days and weeks or even months and years - as was the experience in the Holocaust. At some point, whether due to an exogenous or endogenous shock or by decision of the perpetrators a triggering event acts as a catalyst and propels the cycle of violence forward into mass political violence thresholds. I term this catalyst the "decision point." This moniker encompasses both strategic, premediated decisions to engage in mass political violence and/or allows for perpetrators to take advantage of opportunity structures that emerge from domestic or international shocks to the state. Until this point, actual physical violence remains beneath mass political violence levels. By no means is this model of the generic process of mass political violence deterministic. It is a probabilistic model, forecasting the hypothesized relationship of perpetrators to violence and target groups over time. It is vital to unequivocally state, at any point in this process a simple factor or confluence of events may have the ability to stop, prevent, alter, or stymie conflict thus avoiding mass political violence levels. 
What comes next is two case studies in state-led mass political violence. The Soviet Union and Cambodia under Pol Pot's regime are extreme examples of a state's catastrophic power when used against civilian and target populations.

\section{The Soviet Union}

"Hundreds of thousands of lives were lost-maybe even millions. I can't give an exact figure because no one was keeping count. All we knew was that people were dying in enormous numbers."

- Nikita Khrushchev ${ }^{242}$

\section{Existing Polity Structure}

The brutal tactics employed by Josef Stalin, Nikita Khrushchev and successor chairman of the Soviet Union can trace their origins all the way back to Vladimir Lenin. Bolsheviks/Soviet leaders from Lenin (1917-1924) to Mikhail Gorbachev (1985-1991) employed some form of terror against domestic or international civilian populations. ${ }^{243}$ Even before the February and October 1917 Revolutions, Lenin advocated for a "real, nationwide terror which reinvigorates the country."244 Lenin and his co-conspirators despised the Russian peasantry and those who would come to obstruct his utopian vision for a Communist Russian state. Lenin constantly advocated for "merciless" and "pitiless"

\footnotetext{
${ }^{242}$ Quoted in Jasper Becker, Hungry Ghosts: Mao's Secret Famine (Holt Paperbacks, 1998), p. 37.

243 R.J. Rummel, Lethal Politics: Soviet Genocide and Mass Murder since 1917 (New Brunswick: Transaction Publishers, 1990), p. 217.

${ }^{244}$ Michael Kort, The Soviet Colossus: History and Aftermath, $6^{\text {th }}$ Edition (Armonk, NY: M.E. Sharpe, 2006), p. 129
} 
calls for "gratuitous violence" directed against the peasantry and bourgeoisie. ${ }^{245}$ This "revolutionary violence" was whole heartedly endorsed by Lenin at the outset of the revolution and would be perfected under Stalin's subsequent dictatorship.

In March [February] 1917, the Russian people weakened by years of war, "did little more than riot for several days in their capital city and the old [Tsarist] political order collapsed." 246 At the time of the February Revolution there were no more than 3,000 Bolshevik party members in the capital and fewer than 25,000 nationwide. $^{247}$ Seizing the opportunity, Lenin's Bolsheviks quickly mobilized in response to the sudden power vacuum. In comparison to what lay ahead, the February Revolution was relatively minor in terms of casualties. ${ }^{248}$ Sadly, the so-called October "Revolution" marked the beginning of decades-long war, violence, mass repression, genocide, and mass political violence episodes that reached its zenith under Stalin's dictatorial rule and subsequently stabilized over time. ${ }^{249}$ In November 1917, the Bolsheviks released their "Declaration of the Rights of the People of Russia." This declaration provided all peoples of the Soviet Union a right to "self-determination, including the right to secede." 250 On paper this was a remarkable step toward equality and collective determination. In practice, as will be

\footnotetext{
${ }^{245}$ Kort, The Soviet Colossus, p. 129.

${ }^{246}$ Tsarist Russia used the Julian calendar system. Beginning in 1918, the Soviets switched to the Gregorian calendar system. Kort, The Soviet Colossus, p. 92.

247 Peter Kenez, A History of the Soviet Union from the Beginning to the End (Cambridge: Cambridge University Press, 1999), p. 24.

${ }^{248}$ Kort, The Soviet Colossus, p. 92.

${ }^{249}$ Kenez, A History of the Soviet Union, p. 27-28.

${ }^{250}$ Kort, The Soviet Colossus, p. 135.
} 
demarcated by the Ukraine famine-genocide, efforts at secession were met with barbarous, savage, deadly and merciless policies designed to punish "counterrevolutionaries" and force their obedience to Moscow and the Soviet "dictatorship of the proletariat.",251

Under the direction of Lenin, many Bolshevik leaders were steeped in Marxist theory, like Leon Trotsky. When Stalin took control, he empowered bureaucrats over theoreticians, "men who showered their characteristics were doggedness and a willingness to work at the dull detail of administration." ${ }^{252}$ From the outset, Lenin and Stalin decided to "eliminate, by legal and physical means, any challenge or resistance, even if passive, to their absolute power." 253 In November 1920, the Bolsheviks (Red Army) defeated the anti-Bolshevik White Army under the command of General Pyotr (Peter) Wrangel. ${ }^{254}$ This was the last major counterrevolutionary force to be conquered and opened the way for the Bolsheviks to seize complete control of the state. The same year marked the beginning of Soviet de-Cossackization policies. ${ }^{255}$ Peter Holquist argues that "the de-Cossackization [policy] pursued in 1919 at the height of the civil war, not as a war policy, but as a state policy that happened to be pursued during war... the civil war policy of de-Cossackization is an early demonstration of the Soviet regime's dedication

\footnotetext{
${ }^{251}$ The Soviet's tried to assert their control over Finland, Estonia, Latvia, and Lithuania during their secessionist movements, but failed - at least in the interim period. They succeeded in these assertions of control over Ukraine, Central Asia, Siberia, and the Caucuses. Kort, The Soviet Colossus, p. 135.

${ }^{252}$ Robert Conquest, The Great Terror: A Reassessment (New York: Oxford University Press, 1990), p. 12.

${ }^{253}$ Courtois et al., Black Book, p. 8

${ }^{254}$ Kenez, A History of the Soviet Union, p. 42

${ }^{255}$ Courtois et al., Black Book, p. 8-9
} 
to social engineering." ${ }^{256}$ As such, Cossack populations were slaughtered, "the men shot, the women, children, and the elderly deported, and the villages razed or hundred over to new, non-Cossack occupants." 257

Thanks to Robert Conquest's numerously influential works on the Soviet Union, most notably, The Great Terror, The Nation Killers, and The Harvest of Sorrow we know much more about the inner workings of the Soviet regime and its development of mass terror and repression across its lands. In The Great Terror Conquest shows, contrary to his contemporary colleagues' knowledge, Lenin was just as bloodthirsty as Stalin. The only difference "was that Stalin was simply in a better position to carry out the program Lenin had already plotted." ${ }^{\prime 28}$ I agree with Conquest's assessment that both Lenin and Stalin bear equal culpability. The difference lies in Stalin's ability to successfully achieve his goals while Lenin could not. As most legal prosecutors would argue, success of one's actions and their mere attempt and failure does not reduce one's complicity in such nefarious acts. To summarize, Michael Kort writes:

Stalin's rise to power resulted in a tyranny over the Russian people far worse than Lenin or almost anyone else could have imagined in the 1920s. Yet the evidence is compelling, indeed overwhelming, that Lenin, whatever his intentions, prepared the way not just for Stalin the dictator, but, more fundamentally, for the totalitarian system associated with his name. Before 1917, Lenin created a political party with an ethos that

\footnotetext{
${ }^{256}$ Peter Holquist, “'Conduct Merciless Mass Terror': Decossackization on the Don, 1919” Cahiers du Monde russeVol. 38, No. 1/2 (January-June 1997), p. 127.

${ }^{257}$ Courtois et al., Black Book, 8-9.

${ }^{258}$ Paul R. Bartrop and Steven Leonard Jacobs, Fifty Key Thinkers on the Holocaust and Genocide (London and New York: Routledge, 2011), p. 73.
} 
in the name of revolution justified many activities that repelled many other revolutionaries. That ethos also heartily endorsed a regime based on force so long as it was a "proletarian dictatorship" committed to socialism. Lenin's highly centralized party also required all members to subordinate themselves completely to the collective - all members, that is, except the leader. ${ }^{259}$

Therefore, it is crucial to understand the Bolshevik regime power structure per my framework of mass political violence. The Bolshevik power structure was quite complex - though under Stalin this complicated bureaucracy ultimately had little influence under his totalitarian rule. ${ }^{260}$ The official "public face" of the Bolsheviks resided in the Central Executive Committee, the Soviet Council of People's Commissars was the central lawmaking body, and the Petrograd Revolutionary Military Command (PRMC) was responsible for the actual seizure of power. ${ }^{261}$ Felix Dzerzhinsky, founder of the Cheka a secret police organization - and leading member of the PRMC, characterized the organization as "a light, flexible structure that could swing into action at a moment's notice, without any bureaucratic interference. There were no restrictions when the time came for the iron fist of the dictatorship of the proletariat to smite its foe." ${ }^{262}$ Initially developed during the civil war, the doctrine of what would become known as "war communism" "represented a series of ad hoc measures to combat emergency

\footnotetext{
${ }^{259}$ Kort, The Soviet Colossus, p. 167.

${ }^{260}$ Courtois et al., Black Book, 53.

${ }^{261}$ Ibid, p. 53.

${ }^{262}$ Katherine Verdery, The Political Lives of Dead Bodies: Reburial and Postsocialist Change (New York: Columbia University Press, 1999), p. 12; BBC, p. 53.
} 
situations. $" 263$ Under war communism, the Bolsheviks requisitioned supplies, nationwide many factories, and began to take control over Russia’s vast agricultural sector. ${ }^{264}$

When states direct their minors to engage in mass political violence, regime power is strong. At the top, this high regime power may be semi-egalitarian as was the case under Lenin or hierarchical in nature as was Stalin's leadership structure. Lenin believed in elevating Marxist ideologies, particularly those who could expand upon the practical application of Marxism to the Russian context. However, the regime power under Stalin's totalitarian rule was monopolistic in nature. ${ }^{265}$ Stalin was personally marked with "deep suspiciousness and insecurity" and this paranoia is reason mass political violence under dictatorship became so severe. ${ }^{266}$ The organs of the state (e.g., the Politburo) contrived to meet regularly from 1924-1930; however, even decisions made at this highest level of government could not guarantee decisions were made as the real authority ultimately rested in Stalin's hands. ${ }^{267}$

Since more people were murdered under Stalin's regime than any other - before or after him in the Soviet Union - let's turn to examining, in detail, his regime's power structure and strategy. Conquest's book, The Great Terror is the definitive work on

\footnotetext{
${ }^{263}$ J.P. Nettl, The Soviet Achievement (New York: Harcourt Brace \& Co., 1967), p. 76.

${ }^{264}$ Howard J. Sherman, The Soviet Economy (Boston: Little, Brown, 1969), p. 59; Valentino, p. 101.

${ }^{265}$ Ian Kershaw and Moshe Lewin eds., Stalinism and Nazism: Dictatorships in Comparison (Cambridge: Cambridge University Press, 1997), p. 26.

${ }^{266}$ Kershaw and Lewin, Stalinism and Nazism, p. 49.

267 Julian Cooper and Maureen Perrie eds., Soviet History, 1917-53 (New York: St. Martin's Press, Inc., 1995), p. 105.
} 
Stalin's political purges and mass terror campaign in the 1930s. Conquest perfectly captures Stalin's strategy in the following passage:

Stalin's terror, in fact, begins to show a more rational pattern if it is considered as a statistical manner, a mass phenomenon, rather than in terms of individuals. The absence of strict categories of victims, such as a Trotsky might have listed, maintained the circumspect deviousness of the Purge and avoided presenting any clear-cut target to critics. The effect of terror is produced, he may have argued, when a given proportion of a group has been seized and shot. The remainder will be cowed into uncomplaining obedience. And it does not much matter, from this point of view, which of them have been selected as victims, particularly if all or almost all are innocent. ${ }^{268}$

Conquest shows embedded within Stalin's pursuit of hegemonic power, he used mass political violence as a means to coerce, subdue, and scare the peasantry, bourgeoisie specialists, ethnic groups, and even members of his own political party into submission. The ingenuity of Stalin was to empower leaders just like him. These henchmen were bureaucratically proficient and perhaps equally ruthless. One such principal was Lazar Kaganovich, leader of the Organization and Instruction Section of the Central Committee under the Secretariat. ${ }^{269}$ Kaganovich is noted as an exceptional administrator and unwaveringly harsh enforcer. ${ }^{270}$ Kaganovich was a true believer, in that the ends did in fact justify the means. The ends were anything the party desired - power, control, land,

\footnotetext{
${ }^{268}$ Italics are added for emphasis. Conquest, The Great Terror, p. 67.

${ }^{269}$ Conquest, The Great Terror, p. 13.

${ }^{270}$ E.A. Rees, Iron Lazar: A Political Biography of Lazar Kaganovich (London: Anthem Press, 2013), p.
} 123. 
business, agriculture, or lives. During the terror he told a member of the party that while this "cleansing" occurs mistakes are bound to happen, "When the forest is cut down he chips fly." Conquest notes that Kaganovich added, "That a Bolshevik must be ready to sacrifice not only his life but his self-respect and sensitivity." ${ }^{271}$ Under Stalin's savage reign, he empowered many like-minded figures as Kaganovich into positions of authority. In addition to exterminating political opposition within and beyond the party, Stalin punished whole segments and national groups who expressed independence like the Ukrainians and ordered the systematic deportations of eight entire populations - the Volga Germans, Kalmyks, Chechens, Ingush, Karachai, Balkars, Meskhetians, and Crimean Tatars - both before and during World War II. ${ }^{272}$ For those groups "fortunate" enough to face property dispossession and relocation to concentration camps in lieu of extra-judicial killing, their survival rates were just as low as other contemporary regimes employing concentration camps in the $20^{\text {th }}$ century. ${ }^{273}$ All told, it is clear Stalin's regime tactics, strategy and ruthlessness embody many of the characteristics outlined in the later drafted Genocide Convention.

At this point regime power and perpetrator state capacity begin to overlap with the development of Soviet collectivization policies and mass deportations of ethnic groups. It's worth exploring these two variables together. One of the benefits Stalin and his perpetrators possessed was a unifying ideological belief system that rewarded true believers, at least initially, up until the Great Terror and again after Stalin's death in

\footnotetext{
${ }^{271}$ Conquest, The Great Terror, p. 13.

${ }^{272}$ Robert Conquest, The Nation Killers: The Soviet Deportation of Nationalities (London: Macmillan, 1970).

${ }^{273}$ Robert Conquest, Kolyma: The Artic Death Camps (Viking Adult, 1978).
} 
1953. Both Lenin and Stalin coopted the Communist credo "workers of the world, unite!" in building an apparatus that many of whom would eventually succumb to. To reiterate, in my framework of mass political violence, I use McAdam et al.'s definition of state capacity, "the degree of control that state agents exercise over persons, activities, and resources within their government's territorial jurisdiction."274 The regime's high level of state capacity is one enabling condition that Stalin and other Soviet dictators used to mobilize and murder populations from the hills of Eastern Europe to Siberia and everywhere in between.

At the time of the October 1917 Revolution Russia's population was approximately 140 million, of which 80 percent were peasants. ${ }^{275}$ Serfdom was abolished in 1861 and as a lingering effect, only about half of the peasants in European Russian territory were literate. ${ }^{276}$ During the early years of the Bolshevik Soviet Union, state capacity - as defined above - was in a tenuous situation. As such, the violence in this period is relatively limited compared to later years. After the Bolshevik regime solidified itself as the sole governing authority, initially under Lenin and maximized by Stalin, state capacity became immense. In 1919, Walter Rathenau, a German politician and businessman, characterized Bolshevik Russia as an atrocious, "rigidly oligarchic agrarian republic." ${ }^{277}$ Knowing the shortcomings of this inherited system, the Bolsheviks set out to

\footnotetext{
${ }^{274}$ McAdam et al., p. 78.

${ }^{275}$ Sheila Fitzpatrick, Stalin's Peasants: Resistance and Survival in the Russian Village after Collectivization (New York: Oxford University Press, 1994), p. 19.

${ }^{276}$ Fitzpatrick, Stalin's Peasants, p. 19.

${ }^{277}$ Anthony D’Agostino, The Russian Revolution, 1917-1945 (Santa Barbara: Praeger, 2011), p. 59.
} 
reorganize the government along a federal structure; and under the bureaucratic hands of Stalin, became one of the histories strongest totalitarian governments. Fused within this federal structure was the Communist Party. The party became the connective tissue of the Russian state, everything depended on the party. By 1921, the party banned its opponents - the Mensheviks and anarchists - and had successfully achieved hegemony over the levers of power. ${ }^{278}$

Russian state capacity of the late 1910s and early 1920s cannot compare to contemporary standards of Western industrialized nations. That said, Russian state capacity in terms of its ability to exercise control over persons, activities, and resources is incredible. From 1919 to 1936 , the Bolshevik regime had forced more than 130 million Russian into 240,000 collectivities. ${ }^{279}$ What Stalin called the "revolution from above," by the end of 1931, the regime had invested massive amounts of money into industrializing the nation and increasing its grip over the country's industries and peoples. ${ }^{280}$ Valentino notes, collectivization in the Soviet Union completely altered existing power structures. ${ }^{281}$ Decisions that were previously made at the local and village level were now decided by a centralized bureaucratic system, run by the party. The same year, Stalin would say that there is "no fortress that the Bolsheviks cannot storm." 282 This was true

\footnotetext{
${ }^{278}$ D’Agostino, Russian Revolution, p. 60.

${ }^{279}$ Martin Malia, The Soviet Tragedy: A History of Socialism in Russia, 1917-1991 (New York: Free Press, 1994), p. 199.

${ }^{280}$ Paul Hagenloh, Stalin's Police: Public Order and Mass Repression in the USSR, 1926-1941 (Washington, DC and Baltimore: Woodrow Wilson Center Press and The Johns Hopkins University Press, 2009), p. 89.

${ }^{281}$ Valentino, p. 108.

${ }^{282}$ Hagenloh, Stalin's Police, p. 90.
} 
for physical barriers as well intellectual enclaves. Also in 1931, two million people were believed to be in an "enemy" class - Kulaks - were disposed of property and mass deported into collectives. ${ }^{283}$ All this is to show that state capacity was strong, in terms of McAdam et al.'s definition - an essential ingredient for my framework's analysis on state-directed mass political violence.

Within 12 years of the October Revolution, the Communist Party was "the complete master of all Soviet territory and institutions. And Stalin controlled the party." ${ }^{284}$ Most students of history remember Stalin's purges of the 1930s, however, before he commenced the Great Terror, Stalin began removing political and personal rivals from government and the party. His pre-Great Purge actions allowed Stalin to enhance his personal control over the levers of government and further strengthen Soviet state capacity, as all rural party bosses owed their positions (and their lives) to Stalin. One tool Stalin used to enforce party control over the entire nation was by implementing an internal passport system in $1932 .{ }^{285}$ The internal passport system became a central tool in bolstering regime power and state capacity. The system was developed by Stalin himself, but enforced by local police authorities. In addition to keeping staring and malnourished peasants out of urban centers - where food stores were located - and confined to state induced famine territories (i.e., Ukraine 1932-1933) it was commonly

\footnotetext{
${ }^{283}$ Hagenloh, Stalin's Police, p. 89-90.

${ }^{284}$ Rummel, Lethal Politics, p. 81.

${ }^{285}$ Hagenloh, Stalin's Police, p. 120. For more information on the internal passport system, see Mervyn Matthews, The Passport Society: Controlling Movement in Russia and the USSR (Boulder: Westview Press, 1993); David R. Shearer, "Elements Near and Alien: Passportization, Policing, and Identity in the Stalinist State, 1932-1952," Journal of Modern History 76:4 (2004), 835-81, especially 840-44; Gijs Kessler, “The Passport System and State Control over Population Flows in the Soviet Union, 1932-1940," Cahiers du Monde Russe 42:2-4 (2001), 477-504.
} 
used to apprehend "dangerous" and "harmful criminals." ${ }^{286}$ Within several months, the internal passport system became one of the party's most important policing and enforcement mechanisms against so-called undesirable populations across the Soviet Union. $^{287}$

Deeply connected to the development of the internal passport system was the expansion of the Soviet administrative state and the enhanced powers of centrally located bureaucrats. This highly complex and eventually totalitarian governing structure greatly enabled the Politburo and their minions to crackdown on "dissident" populations. Sheila Fitzpatrick writes, "Extrajudicial repression was so thoroughly intertwined with the everyday operation of the policy system by the mid-1930s, even regarding relatively petty crimes, that reforms of the judicial system ultimately made little difference in the overall direction of Soviet criminal justice.”288 By 1934, there were some efforts made to control extrajudicial actions on the part of political police authorities. However, Soviet bureaucracy had become so powerful that Richard Sakwa called it "a hydra-headed beast." ${ }^{289}$ He goes on to note that the principal benefit of this immense internal political state apparatus was to secure the Bolshevik's hegemony in domestic power politics. ${ }^{290}$ As was written, the party controlled the state and Stalin controlled the party. The channeling of all power through a central authority greased the skids for Stalin - an exceptionally

\footnotetext{
${ }^{286}$ Hagenloh, Stalin's Police, p. 120.

${ }^{287}$ Hagenloh, Stalin's Police, p. 120.

${ }^{288}$ Hagenloh, Stalin's Police, p. 149.

${ }^{289}$ Cooper and Perrie, Soviet History, p. 45.

${ }^{290}$ Cooper and Perrie, Soviet History, p. 45.
} 
knowledge bureaucrat - to seize total control of the State and therefore the country. Stalin himself possessed more authority than the Politburo collectively, and as such is personally responsible for wielding the Soviet sickle and hammer against millions of civilians throughout his reign of terror.

The final criterion of the Soviet existing polity structure to assess is the society's appetite for participating in violence. As Table 3.2 shows, we would expect to see a population that is not supportive of widespread mass political violence, or at minimum possesses little appetite for personal involvement in killing. There are several ways to evaluate Russian society's active or passiveness. We may start with the October Revolution. If large segments of society were involved, it is logical to conclude that they would remain involved and perhaps supportive of Bolshevik violence moving forward. Historians and political scientists who have studied social movements and revolutions have long asked whether the October 1917 Revolution was a coup d'état or an actual revolution of the working class. ${ }^{291}$ There is three schools of thought regarding the October Revolution. First, a "liberal" view argues that the revolution was little "more than a putsch imposed on a passive society." 292 For these scholars the revolution was simply a clever marketing trick of a few elite conspirators that fomented a coup against the weakening Provisional Governmental Authority. If this view were valid, it would support my argument of a passive society. The second perspective on the October Revolution comes from a Marxist or critical approach to these events. They argue "that the events of October 1917 were the logical, foreseeable, and inevitable culmination of a

\footnotetext{
${ }^{291}$ Kenez, A History of the Soviet Union, p. 27-33.

${ }^{292}$ Courtois et al., Black Book, p. 39.
} 
process of liberation undertaken by the masses, who consciously rallied to Bolshevism. ${ }^{293}$ This view is perhaps a favorable analysis of the revolution and its "popular" support. That said, once the coup or revolution began, there is evidence to support the argument that workers and disaffected soldiers joined the Bolshevik cause. What we should ask is, is this evidence indicative of a broad nationwide movement, particularly, one that is in support of mass political violence? The answer to this question is convincing. There is a difference between support in theory and actual, tangible movement from the masses toward widespread violence. The third view of the revolution finds common ground between these two scholarly camps, by arguing that the "uprising of October 1917 was simultaneously a mass movement and an event in which so few people actually took part." ${ }^{294}$ There is evidence to a degree that supports mass mobilization during this period. I would argue that this mobilization of society was in support of opposition to Bolshevism and a reflection of the civil war and not tacit or explicit support for mass political violence directed against civilian populations.

Between 1923-1927 there was a fleeting pause in the confrontation between the regime and society - namely the peasantry. ${ }^{295}$ In March 1923, Lenin had been suffering from his third stroke which had left his partially paralyzed and left him unable to speak. ${ }^{296}$ The following January Lenin had finally succumbed from complications with

\footnotetext{
${ }^{293}$ Courtois et al., Black Book, p. 40.

${ }^{294}$ Courtois et al., Black Book, p. 40.

${ }^{295}$ Courtois et al., Black Book, p. 132.

296 Richard Pipes eds., The Unknown Lenin: From the Secret Archive, trans. of Russian documents by Catherine A. Fitzpatrick (New York: Yale University Press, 1998), p. 16.
} 
his stroke and passed. During this temporary reprieve of violence, and subsequent fight for control of the state, the peasantry and society writ large was able to rest and recover from mass repression and disaster agricultural policies. Unfortunately, this respite did not last long.

By the end of the decade, Stalin had begun to solidify control over the party and reinstitute repressive policies nationwide. The generally accepted view of state-society relations during this time period is that regime acted and society re-acted to the state's efforts at "chang[ing] their entire manner of life, forsake their immemorial customs and rights." ${ }^{297}$ Despite this conventional notion of state-society relations, there are those who have pushed for nuance. Fitzpatrick is one such scholar. She argues that this totalitarian model of state-society relations "gives a one-sided and simplistic picture of the interaction of state and society." ${ }^{" 298}$ Yes, the Soviet regime sought to dramatically transform society through Communism and specific socialist policies (i.e., collectivization policies). However, Fitzpatrick contends that the lack of resistance to these policies is not indicative of a passive society, but more of their inability to mobilize against the state. ${ }^{299}$ Irrespective of the exact reason why society did not or could not mobilize, for the purposes of my analysis, the important notation is that society did not partake (regardless of the reason) in mass political violence outside of persons affiliated with the regime.

\footnotetext{
${ }^{297}$ Adam B. Ulam, Stalin: The Man and His Era (New York: The Viking Press, 1973), p. 289.

${ }^{298}$ Sheila Fitzpatrick, "New Perspectives on Stalinism” The Russian Review 45:4 (October 1986), p. 372.

${ }^{299}$ Fitzpatrick, "New Perspectives on Stalinism,” p. 366.
} 


\section{Cycle of Violence}

To a large extent, the section breaks here are somewhat arbitrary but nonetheless a helpful guide to unpacking mass political violence under the Soviet Union. Much of what has already been written under the previous heading applied to the cycle of violence. Therefore, I will not belabor the points. For mass political violence to occur, perpetrators must act in response to a perceived threat. What was this perceived threat under the Bolshevik / Soviet regime? Depending on the time period, this threat came from ethnonational groups, class enemies, political opponents, or from within the Communist regime. It's crucial to regime that the mere perception of a threat does not need to be based in any objective reality. This is perhaps most evident during the Great Terror and its political purges by Stalin. In short, the Leninist-Stalinist regime viewed any person uncommitted to the ideological goals of Communism a threat. Martin Latsis, one of the first heads of the Cheka, a secret political organization, issued an order on November 1, 1918 saying, "We didn’t make war against any people in particular. We are exterminating the bourgeoisie as a class. In your investigations [as political police agents] don't look for documents and pieces of evidence about what the defendant has done, whether in deed or in speaking or acting against Soviet authority. The first question you should ask him [or her] is what class he [or she] comes from, what are his [her] roots, his [her] education, his [her] training, and his [her] occupation." ${ }^{300}$ Substitute "what class" he or she comes from with what ethnic group and the same order applies during much of the Soviet's reign.

\footnotetext{
${ }^{300}$ Courtois et al., Black Book, p. 8 .
} 
The Soviet Union is an extreme case within this extreme phenomena of mass political violence. The Communist dictatorship engaged in near perpetual violence against varying populations from its inception to collapse. ${ }^{301}$ Since the state and its perpetrators continually acted on perceived threats and violence therein. I argue that they existed in a constant state of "fear" and thus a constant state of cycle of violence (see Figure 4.1). Violence was enacted upon when decision points were individually reached vis-à-vis social groups, political opponents, or entire populations. "Lighting never strikes from a clear blue sky. Stalin could not have existed without certain preconditions.... the Bolsheviks called their regime the "dictatorship of the proletariat" and they certainly lived up to this name. ${ }^{302}$

Perhaps part of the reason the Bolsheviks viewed so many populations and groups as threats to their rule lay in their ideology. Belief in Marx's idea “...that human society would not be "liberated" without achieving unity. And, except for despotism, there is no other technique known to produce a unity of society; no other way of suppressing the tensions between civil and political society...no other means to remain the conflicts...but the destruction of the individual." ${ }^{, 303}$ I will not delve into the debate on whether Stalinism and its totalitarian nature is a logical, inevitable conclusion of Marx's ideas and their application. For one, this debate is far too cumbersome to expand upon here. Second, for the purpose of this study on mass political violence the answer to such a question is a

\footnotetext{
${ }^{301}$ Rummel, Lethal Politics.

${ }^{302}$ Kenez, A History of the Soviet Union, p. 104.

303 Leszek Kolakowski, "Marxist Roots of Stalinism” in Robert C. Tucker eds., Stalinism: Essays in Historical Interpretation (New York: W.W. Norton and Company, Inc., 1977), p. 286.
} 
diversion. For me, what matters is the actions of these elites and in assessing their motivations, not in philosophical debates on the application of Marxism. ${ }^{304}$

To cap this discussion on the "destruction of the individual," we need to look no further than Stalin's Great Terror campaign of the late 1930s. Between 1936-1938 hundreds of thousands of Soviet citizens were arrested or accused of crimes against the state. ${ }^{305}$ The accused were given political show trials and many were summarily executed or imprisoned. ${ }^{306}$ In 1937 and 1938 the NKVD, a so-called law enforcement agency, shot 681,692 people for political and non-political crimes. Moreover, 1,575,259 were arrested by the NKVD; of which 87 percent were charged with political offenses against the state and the NKVD "achieved" an 85 percent conviction rate. ${ }^{307}$ Considering this widespread repression of society, it is not surprising that society would remain passive to the state's wishes of total control.

\section{Decision Points}

A complete accounting of crimes committed by the Bolshevik/Soviet regime is too copious to analyze in great detail here. Frankly, the regime was far too successful in killing to account for all its atrocities. Tomes of books have been written on each episode and still more are needed. For the purpose of illustrating state-directed mass political

\footnotetext{
${ }^{304}$ Nanci Adler, Victims of Soviet Terror: The Story of the Memorial Movement (Westport, CT: Praeger, 1993).

${ }^{305}$ David Priestland, Stalinism and the Politics of Mobilization: Ideas, Power, and Terror in Inter-war Russia (Oxford: Oxford University Press, 2007), p. 1.

${ }^{306}$ Priestland, Stalinism and the Politics of Mobilization, p. 1.

${ }^{307}$ Priestland, Stalinism and the Politics of Mobilization, p. 1.
} 
violence, let's examine the 1932-1933 Ukraine famine that has been called on one hand a catastrophic natural disaster to a man-made famine-genocide. This section explores the Ukrainian tragedy and unpacks the decision points of Stalin's regime to induce and sustain mass political violence against the Ukrainian people.

The decision by perpetrators to enact mass political violence can take several forms. First, perpetrators may view the perceived threat from a group or population to be substantial but not imminent. Therefore, the way they enact violence on this group could be as a result of "slow-burn" tactics. A drawn out assault on the group's culture, property, finances, civil and political rights, and ultimately their lives. The second type of decision to execute violence could stem from a triggering event. There could be some exogenous or endogenous shock to the state. Perhaps an assassination that traumatizes the nation, an explosion or fire-bombing of government offices, or even severe economic collapse. Whatever the proximate cause, the decision here would be to at upon this course with swift vengeance in the form of mass political violence. In the case of Ukraine, the 193233 famine permanently ended talks of revolution or independence. ${ }^{308}$ The famine was only part of the story. As Lenin once said, "How can you make a revolution without firing squads?" ${ }^{\prime 309}$ There is a clear distinction between the way Lenin and Stalin viewed the use of mass political violence. Lenin's acts “might have been partially justified as the desperate acts of a desperate ruler to curb political chaos... [While] Stalin...was deliberate, calculated, [and a] cold-blooded effort at complete control that was not

\footnotetext{
${ }^{308}$ At least until the collapse of the Soviet Union.

${ }^{309}$ Peter Julicher, "Enemies of the People" Under the Soviets: A History of Repression and Its Consequences (Jefferson, NC: McFarland \& Company, Inc., 2015), p. 7.
} 
provoked by events." ${ }^{310}$ In the case of Ukraine, Stalin's reaction to a decade's long effort at revolution and independence seemed to instill in him deep anger and it manifested itself in harsh, dispossessive policies that inevitably killed millions.

Three questions will guide my discussion of the Great Famine. First, why did people starve? Was this tragedy avoidable? And, third, if the answer to the last is yes, why wasn't the famine avoided? Let's begin with a brief overview. By early 1932 there was ample evidence - both in public accounts and from secret, internal police reports that the people of Ukraine were beginning to starve. ${ }^{311}$ Anne Applebaum writes that "in March [1932] a medical commission found corpses lying on the street in a village near Odessa. No one was strong enough to bury them" because of their malnutrition. ${ }^{312}$ Counting civilian casualties is an incredibly difficult task. One that is exacerbated when the regime in control of the territory actively hides and classifies the true death tolls. As a result, there are many estimates of the victims that commonly range between 3.2 and 10 million people who died in Ukraine between 1932-1933 from starvation and politically motivated murders. ${ }^{313}$ Unlike the previous famine of 1921-1922, the Soviet Union denied

\footnotetext{
${ }^{310}$ Adler, Victims of Soviet Terror, p. 32; Conquest, The Great Terror, p. 376-377.

311 Anne Applebaum, Red Famine: Stalin's War on Ukraine (New York: Doubleday, 2017), p. xxv.

312 Applebaum, Red Famine, p. xxv.
}

${ }^{313}$ Michael Ellman cites 3.2 million in his article, "Stalin and the Soviet Famine of 1932-133 Revisited" Europe-Asia Studies 59:4 (June 2007), pp. 663-693 and he attributes this number to S.V. Kul'chits'kii, Golod 1932-1933 gg. v. Ukraine kak genotsid (Kyiv: Institute of Ukrainian History and Ukranian Academy of Sciences, 2005), p. 186; Anne Applebaum says 3.9 million Ukrainians died of hunger between 1931-1934 and 5 million total across the entire Soviet Union in her book Red Famine: Stalin's War on Ukraine (New York: Doubleday, 2017), p. xxvi; Andrea Graziosi argues that there were approximately five million victims in her work "The Soviet 1931-1933 Famines and the Ukrainian Holodomor: Is a New Interpretation Possible, and What Would Its Consequences Be?" Harvard Ukrainian Studies 27:1/4 (2004-2005), p. 97; Stephanie Courtois et al. argue that six million perished The Black Book of Communism: Crimes, Terror, Repression (Cambridge: Harvard University Press, 1999), p. 159; and Robert Conquest contends about 10 million in The 
the famine was occurring and that any assistance was needed for the people of Europe's bread basket. ${ }^{314}$ The government made show efforts at transporting foreign dignitaries like French senator Edouard Herriot throughout the country to show them "model children's garden" so that they could deny any reports of widespread famine. ${ }^{315}$ Notwithstanding the French blindness to Ukraine's reality, both German and Italian officials made reports on the growing catastrophe. ${ }^{316}$

Why did people starve? The famine is only part to blame. Soviet authorities ordered grain and food supplies to be guarded and housed in central locations to avoid illegal seizure by locals. In 1932, peasants and farmers began to siphon off parts of the harvest during night time in hope of feeding themselves and their families. Then, "to collect the grain... central authorities had to send out new shock troops, recruited in the towns from among [local] Communists and Komsomols." ${ }^{317}$ Arrests, searches, and seizures took the nation by storm. Many Ukrainians were charged with stealing from the harvest and could be sentenced to 10 years in prison or execution. ${ }^{318}$ Between August 1932 and December 1933, greater than 125,000 people were convicted under this crime and 5,400 sentenced to death. ${ }^{319}$ There was concern over the severity of this growing

Harvest of Sorrow: Soviet Collectivization and the Terror-Famine New York and Oxford: Oxford University Press, 1986), p. 3.

${ }^{314}$ Courtois et al., Black Book, p. 159.

${ }^{315}$ Courtois et al., Black Book, p. 159.

${ }^{316}$ Courtois et al., Black Book, p. 160.

${ }^{317}$ Courtois et al., Black Book, p. 161.

${ }^{318}$ Courtois et al., Black Book, p. 162.

${ }^{319}$ Courtois et al., Black Book, p. 162. 
national crisis expressed from within the party. In April 1933, famous Soviet novelist Mikhail Sholokhov wrote two letters to Stalin regarding the barbarous actions of Soviet troops forcing peasants and workers to hand over their remaining food stores to the party. ${ }^{320}$ In response, Stalin wrote,

"To avoid being mistaken in politics - and your letters, in this instance, are not literature, they are pure politics - one must see another aspect of reality too...the workers in your district...went on strike, carried out acts of sabotage, and were prepared to leave workers from the Red Army without bread!... these people deliberately tried to undermine the Soviet state. It is a fight to the death, Comrade Sholokhov!"321

What Stalin omits is that these workers and peasants were simply trying to feed themselves and not bring harm to the Soviet state. Was this calamity avoidable? Further bringing the state back into this famine-genocide, it is during this period that Stalin implemented the internal passport system to keep - in part - starving Ukrainians in these food deserts. Here, if Stalin would have not implemented the passport system, allowed Ukrainians to leave, or even more simply provided them with their own food that they grew, the famine could have been minimized and millions of deaths averted. It is clear through Stalin's actions that the Ukrainian 1932-1933 famine was if not brought about by his disastrous collectivization policies previously, certainly the effects and sustained weaponization of food resulted in unimaginable levels of death and mass political violence. E.A. Rees and J. Arch Getty argue that much of the violence during this period (and in later years) can be attributed to disputes between the central Soviet authority and

\footnotetext{
${ }^{320}$ Courtois et al., Black Book, p. 165.

${ }^{321}$ Courtois et al., Black Book, p. 166-167.
} 
individual localities. ${ }^{322}$ This revelation has become increasingly self-evident in recent years as more documents are released that shed light on "man's" role in this faminegenocide. ${ }^{323}$

\section{The Victims}

At the very least, a few words must be expressly written on the many victims of the Soviet Union. There are unfortunately far too many to accurately count or recite in this venue. The vast majority of people killed between 1917 and 1991 were done so in the first few decades of Soviet rule. ${ }^{324}$ Similar to counting civilian casualties in the Ukrainian famine, cataloguing accurate deaths tolls across eight decades is an even more difficult task. According to R.J. Rummel, up to about 62 million people were killed between the Russian civil war, new economic policies of the 1920s, collectivization efforts, the Great Terror, and throughout the end of Gorbachev's tenure. ${ }^{325}$ Some have criticized Rummel's figures as inflationary; though he admits it's better to overestimate than neglect to include possible victims in an analysis of democide. Nevertheless, using Rummel's estimate of 62 million victims, two-thirds of them perished in concentration camps and political prisons. ${ }^{326}$ Victims here included domestic political opponents throughout the eight

\footnotetext{
${ }^{322}$ E.A. Rees eds., Centre-Local Relations in the Stalinist State, 1928-1941 (New York: Palgrave Macmillan, 2002), p. 6.

${ }^{323}$ I say here "man's" role, because there is a gendered/sex dynamic in many episodes, including this genocide, that most perpetrators are male. See Elisa von Joeden-Forgey, "Genocidal Masculinity" in Adam Jones eds., New Directions in Genocide Research (London and New York: Routledge, 2012), p. 76-95.

${ }^{324}$ Rummel, Lethal Politics, p. 6-7.

${ }^{325}$ Rummel, Lethal Politics, p. 6-7.

${ }^{326}$ Rummel, Lethal Politics, p. 6-7.
} 
decades of Soviet rule and includes prisoners of war from Poland and Germany during World War II. ${ }^{327}$ These figures include class enemies like Bourgeoisie specialists and ethnic groups like the Cossacks and Kulaks and national groups like in the Ukrainian famine. Some victims were summarily executed on the spot, other given show trails and thereafter executed, and the unfortunate others carted off to concentration camps in Siberia, or fell victim to rape and plundering. To stress, the extent executions were commonplace, between 1937-1938, three-fourths of a million people were executed without a trail or some form of legal adjudication because they were labelled as "counterrevolutionaries." 328

When these dictators and their henchmen could not plausibly deny the mass political violence episodes, they invented stories to justify the violence or gloss over its excessive nature. ${ }^{329}$ First came the justifications "when you cut down a forest, the shavings get blown away" or "you can't make an omelet without breaking a few eggs."330 Next came the cover ups. The concentration camps were referred to as the "re-education system," the dictators, autocrats, tyrants, and perpetrators were the "educators," and prisoners were forcibly "invited" to participate in the re-education system. ${ }^{331}$ In one of the greatest attempts at covering up or explaining away crimes of the state, Khrushchev announced after Stalin's death that these atrocities were the result of Stalin and Stalin

\footnotetext{
${ }^{327}$ Courtois et al., Black Book, p. 129-130.

${ }^{328}$ J. Arch Getty and Oleg V. Naumov, trans. by Benjamin Sher, The Road to Terror: Stalin and the SelfDestruction of the Bolsheviks, 1932-1939 (New Haven and London: Yale University Press, 1999), p. 1.

${ }^{329}$ Courtois et al., Black Book, p. 19.

${ }^{330}$ Courtois et al., Black Book, p. 19.

${ }^{331}$ Courtois et al., Black Book, p. 19.
} 
alone; not crimes of Communism or the state writ large. ${ }^{332}$ However we know from the historical record that this is simply false. Notwithstanding perpetrator's individual exuberances in killing but by observing that violence did not begin or end with Stalin.

\section{Cambodia}

"All we need to build our country is a million good revolutionaries No more than that. And we would rather kill ten friends than allow one enemy to live [Quoting a Khmer Rouge spokesperson]."

- Pin Yathay ${ }^{333}$

\section{Existing Polity Structures}

With the exception of Laos, Cambodia was "more isolated and landlocked than any other Southeast Asian country." ${ }^{334}$ Cambodia is a small country, about the size of South Dakota. Her "geography, we are taught, resembles a bowl, with a vast central plain surrounded by a series of mountains." 335 The small Southeast Asian nation resides in a tropical climate, regularly experiencing heavy rains, thunderstorms, and flooding throughout. ${ }^{336}$ Ben Kiernan, one of several definitive voices on the nation wrote,

\footnotetext{
${ }^{332}$ Courtois et al., Black Book, p. 23.

${ }^{333}$ Pin Yathay, Stay Alive, My Son (Ithaca and London: Cornell University Press, 1987) p. 248.

${ }^{334}$ Ben Kiernan, The Pol Pot Regime: Race, Power, and Genocide under the Khmer Rouge, 1975-79 (New Haven and London: Yale University Press, 2008), p. 4.

${ }^{335}$ James A. Tyner, The Killing of Cambodia: Geography, Genocide and the Unmaking of Space (Burlington, VT: Ashgate, 2008), p. 1.

${ }^{336}$ Ibid, p. 1.
} 
"Compared to neighboring Thailand and Vietnam, it was geographically compact, demographically dispersed, linguistically unified, ethnically homogenous, socially undifferentiated, culturally uniform, administratively unitary, politically undeveloped, economically undiversified, and educationally deprived." ${ }^{337}$ Pre-revolutionary Cambodia was 80 percent Buddhist, 80 percent peasant, and 80 percent Khmer. ${ }^{338}$ Village life was decentralized and quite individualistic. The nuclear family composed the "social core" of society. ${ }^{339}$ Despite being majority peasant, there were two Cambodias. One, the dominant, consisted of rural village life and the second for those in urban centers (small towns and cities). ${ }^{340}$ With four-fifths of the population residing in rural lands, the plantation came to be the most significant player in pre-industrial Cambodian economy. ${ }^{341}$ The Khmer work force was characterized as having low productivity. As such, the French during colonial rule, imported a lot of Vietnamese to support plantation work. ${ }^{342}$ This influx of Vietnamese workers would eventually be one cleavage in revolutionary Cambodia.

Between 1954 and 1970, Cambodia underwent a rapid change - particularly in education. ${ }^{343}$ In 1953 there were eight high schools, by 1967 there were 200, eleven

\footnotetext{
${ }^{337}$ Kiernan, Pol Pot Regime, p. 4.

${ }^{338}$ Kiernan, Pol Pot Regime, p. 5; Craig Etcheson, The Rise and Demise of Democratic Kampuchea (Boulder, CO: Westview Press, 1984), p. 16.

${ }^{339}$ Kiernan, Pol Pot Regime, p. 5.

${ }^{340}$ Ibid, p. 5.

${ }^{341}$ Etcheson, Rise and Demise, p. 7.

${ }^{342}$ Ibid, p. 7.

${ }^{343}$ Kiernan, Pol Pot Regime, p. 6.
} 
universities with a combined student population of about 11,000, and over one million educated youth across the nation. ${ }^{344}$ Moreover, nearly all Khmer were able to achieve basis literacy. Nevertheless, disparities remained in the population - particularly the peasantry. There were two peasantries: the majority were poor, indebted small landowners and a minority of the peasantry were landless. ${ }^{345}$ Politically, the 1950 s and 1960s were a period of "moderate pluralism." "346 This moderation was principally led by former King Norodom Sihanouk who renounced the throne on March 2, 1955, so that he could actually engage in politics. ${ }^{347}$ He formed the Sangkum Reastr Niyum (or Sangkum) party which subsequently captured 83 percent of the vote and all 91 seats in the assembly. ${ }^{348}$ Despite this seemingly political cohesion at the national level under Sangkum, many cleavages and growing tensions were masked at the local level. ${ }^{349}$ Craig Etcheson writes, "Beneath the artificial unity of the Sangkun political movement, competing interests simmered and struggled for representation. Untended cleavages depended between ethnic Khmer majority and the various ethnic minorities, between the urban and rural economies and among the urban elite."350

\footnotetext{
${ }^{344}$ Kiernan, Pol Pot Regime, p. 6.

${ }^{345}$ Kiernan, Pol Pot Regime, p. 6-7.

${ }^{346}$ Etcheson, Rise and Demise, p. 9.

${ }^{347}$ Etcheson, Rise and Demise, p. 9.

${ }^{348}$ Etcheson, Rise and Demise, p. 9.

${ }^{349}$ Etcheson, Rise and Demise, p. 9.

${ }^{350}$ Etcheson, Rise and Demise, p. 9.
} 
Saloth Sar, also known as "Pol Pot," "Pol," "87," and "Brother Number 1," sought a radical transformation in Cambodia and "attempt[ed] to implement total communism in one fell swoop, without the long transitional period that seemed to be one of the tenets of Marxist-Leninist orthodoxy. ${ }^{351}$ The name Khmer Rouge was always rejected by Pol Pot and his followers. Sihanouk was the first to use this term to describe the communist guerrilla movement in the late 1960s. In Cambodia the term "Polpotists" is more common, but as Jean-Louis Margolin notes, this term allowed other high ranking leaders such as Ieng Sary and Khiev Samphan to distance themselves from the "personalistic" regime of Pol Pot. ${ }^{352}$ In reality, they went along with or even orchestrated much of these heinous crimes Cambodia's transformation into Democratic Kampucheathe official name of Khmer Rouge controlled Cambodia - began more than two decades before the civil war of $1970 .{ }^{353}$ Japan lost control of Cambodia at the end of World War II. Following Japan's defeat and subsequent surrender of all colonial territories, France began to reassert their claim over the region. By 1954, an independence movement overthrew the French and saw the emergence of a viable communist party. ${ }^{354}$

Like the Soviet Union, Cambodia's internal conflict was influenced by external war. By March 1970, the Vietnam War had completely engrossed the country. Pol Pot's success in capturing control of Cambodia, would not have occurred without "US economic and military destabilization...which began in 1966 after the American

\footnotetext{
${ }^{351}$ Courtois et al., Black Book, p. 577.

352 Courtois et al., Black Book, p. 577.

${ }^{353}$ Kiernan, Pol Pot Regime, p. 15.

354 Kiernan, Pol Pot Regime, p. 15.
} 
escalation in next-door Vietnam and peaked in 1969-73, with the carpet bombing of Cambodia's countryside by American B-52s. This was probably the single most important factor in Pol Pot's rise." 355 The US dropped about 161,000 tons of bombs on the Cambodian countryside, targeting Vietnamese communist forces. ${ }^{356}$ It is unknown exactly how many civilians died as a result of these bombing missions Kiernan estimates up to 150,000 civilian deaths from US bombing campaigns from $1969-73 .{ }^{357}$ What is certain, the Khmer Rouge used the bombings and subsequent civilian massacres as a recruitment tool. After one such attack in Kompong Cham province, a survivor said, "some people ran away...others joined the revolution.",358

The Khmer Rouge engaged in guerrilla combat against the Cambodian government from 1970-75. Etcheson breaks the civil war period down into seven parts: the initial collapse of government (March-June 1970), retrenchment, counterattack, and parry (July 1970 to August 1971), a period of tactical blunders (August-December 1971), attrition (December 1971 to December 1972), attack and repulse (January-August 1973), the rise of siege warfare against urban areas (August 1973 to December 1974), and finally the victory by Khmer Rouge (January-April 1975). ${ }^{359}$ By 1972, the Khmer Rouge had encircled many urban areas, eventually cutting them off from their supply chains. In

\footnotetext{
${ }^{355}$ Kiernan, Pol Pot Regime, p. 16.

${ }^{356}$ Kiernan, Pol Pot Regime, p. 18-19.

${ }^{357}$ Kiernan, Pol Pot Regime, p. 24.

${ }^{358}$ Kiernan, Pol Pot Regime, p. 349-57.

${ }^{359}$ Etcheson, Rise and Demise, p. 103.
} 
1973, the Khmer Rouge broke with neighboring communist Vietnam. ${ }^{360}$ On April 17, 1975, the civil war ended, Pol Pot and his loyal companions captured Phnom Penh, the capital, thereby closing one chapter and beginning another. The speed by which the Khmer Rouge moved to implement their radical transformation is perhaps unmatched by any other regime in modern history. Within seven days, money was abolished, mass deportations of all urban areas were well underway, and within two years "total collectivization was achieved." 361

Pol Pot's revolution took two parts. First, he moved to overthrow the existing political order. Then, he moved to re-make society by his own vision, that being, a communist utopia. To achieve this new Democratic Kampuchea, he first had to eliminate the existing political and social orders, so that he could reconstruct them by his own vision. ${ }^{362}$ One significant departure in Cambodian communism from that of the Soviet Union, was that Pol Pot and the new regime deeply valued their privacy. One Khmer Rouge mantra was, "if you preserve secrecy, half the battle is already won." ${ }^{363}$ It took Pol Pot and his followers about one year to set up the government and all of which was done in secret from public view.

The regime power accumulated by Pol Pot's Communist Party of Kampuchea (CPK) is nearly unprecedented in modern history. ${ }^{364}$ Brother Number One was named

\footnotetext{
${ }^{360}$ Courtois et al., Black Book, p. 582-83.

${ }^{361}$ Courtois et al., Black Book, p. 572.

${ }^{362}$ Etcheson, Rise and Demise, p. 2.

${ }^{363}$ Philip Short, Pol Pot: Anatomy of a Nightmare (New York: Henry Holt and Company, 2004), p. 5.

${ }^{364}$ Kiernan, Pol Pot Regime, p. 27.
} 
Prime Minister of Democratic Kampuchea and chairman of the military commission. ${ }^{365}$ The principal standing committee was composed of nine members and supported by 11 or 12 candidate members. ${ }^{366}$ This committee was often referred to as the "high organization," or "the center," which was the senior decision-making body in Democratic Kampuchea. Contrary to the Soviet Union, we still decades later know very little about the leaders of the Khmer Rouge because they rarely spoke publically or published materials themselves. ${ }^{367}$ However, we do know that CPK leaders sought a radical transformation of society and in so doing relied heavily upon mass political violence and terror. ${ }^{368}$

It's clear that the CPK possessed enormous state capacity - as described - to order and complete an evacuation of all urban areas within one week of taking Phnom Penh. As early as 1970, CPK officials had begun constructing a "six-tiered framework of political organization" that connected the party to every resident in newly occupied territories during and after the civil war. ${ }^{369}$ As the CPK advanced, this political framework became one crucial element in the party's ability to manage the population across a wide swath of land. The Khmer Rouge tapped into Cambodian society's already hierarchical social structure; even if they would eventually destroy it down the road. Democratic Kampuchea was segregated administratively into seven geographical zones.

\footnotetext{
365 Kiernan, Pol Pot Regime, p. xx.

${ }^{366}$ Kiernan, Pol Pot Regime, p. xx-xxii.

${ }^{367}$ Courtois et al., Black Book, p. 579.

${ }^{368}$ Etcheson, Rise and Demise, p. 135.

${ }^{369}$ Etcheson, Rise and Demise, p. 127.
} 
Each zone was sub-divided into regions, each region was composed of several districts, and each district possessed sub-districts (which were village level principalities). ${ }^{370}$ The Southwest zone in Democratic Kampuchea became Pol Pot's power based in $1976 .{ }^{371}$ Though Polpotism has strong roots here dating back to 1971, Pol Pot's CPK possessed a relative high degree of state capacity - that being his party's ability to "exercise [control] over persons, activities, and resources" - most clearly demonstrated in his ordering of mass deportations after April 17, 1975.

Finally, Cambodian society possessed little appetite for participating in widespread mass political violence. Ravaged by five years of civil war and near constant harassment bombing by US B-52s in the countryside, Cambodians by enlarge wanted to remain out of these conflicts. In digging deeper, we need to assess the two Cambodias: urban elites and the rural peasantry. For Sihanouk, or his predecessors, obtaining support of the urban elite was necessary to maintaining rule. ${ }^{372}$ Similarly, "without at least the tacit ambivalence, if not the support, of the rural masses it is an unimaginable task to govern the nation." ${ }^{373}$ As Kiernan and Malcolm Caldwell note, a small group of individuals is not sufficient to make a revolution successful. ${ }^{374}$ The peasantry became discontent and highly motivated by the protracted conflict. This widespread discontent allowed the CPK to top into these reservoirs of hate and recruit from the masses during

\footnotetext{
${ }^{370}$ Etcheson, Rise and Demise, p. 66-68.

${ }^{371}$ Michael Vickery, Cambodia: 1975-1982 (Boston, MAL South End Press, 1985), p. 86.

${ }^{372}$ Etcheson, Rise and Demise, p. 61.

${ }^{373}$ Etcheson, Rise and Demise, p. 61.

${ }^{374}$ Etcheson, Rise and Demise, p. 124.
} 
their campaign to retake the state. ${ }^{375}$ However, Valentino notes, revolution and the implementation of mass murder are two very different tasks. The latter does not require widespread support of the masses as a necessary condition. In the case of Cambodia, this was certainly true.

\section{Cycle of Violence}

In Politics, Aristotle advocates for moderation to ensure political stability. When the Khmer Rouge took Phnom Penh on April 17, 1975, moderation was not part of their strategy. ${ }^{376}$ Cambodia's history of political diversity and ethnic heterogeneity - in modern times - posed a problem for CPK leaders; thus, they saw enemies in every segment of society. ${ }^{377}$ When the Khmer Rouge took Phnom Penh, their level of brutality came as a surprise to most observers. ${ }^{378}$ Dissent was not tolerated. Resistance was viewed as a threat, not only to the regime's ideational goals, but to its stability and legitimacy. Thus, all resistance - active and passive in many instances - was to be squashed. The Khmer Rouge quickly moved to suppress all civil, political, and economic freedoms. ${ }^{379}$ Broadly analyzed, the Khmer Rouge used two methods in subduing and murdering individuals from primarily four categories. Most Cambodians either directly murdered or

\footnotetext{
${ }^{375}$ Etcheson, Rise and Demise, p. 126.

${ }^{376}$ Etcheson, Rise and Demise, p. 144.

${ }^{377}$ Kiernan, Pol Pot Regime, p. 26-27.

378 Ben Kiernan, How Pol Pot Came to Power: Colonialism, Nationalism, and Communism in Cambodia, 1930-1975, $2^{\text {nd }}$ Edition (New Haven and London: Yale University Press, 2004), p. xxxix.

${ }^{379}$ Edward Kissi, Revolution and Genocide in Ethiopia and Cambodia (Lanham: Lexington Books, 2006), p. xvii.
} 
those that died from state policies, did so from mass deportations or in political purges. There are four broad categories of persons the CPK targeted: ethnic groups, political opponents, urbanities, and intellectuals. Cambodians who did not accept the Khmer Rouge's leadership were often called "traitors" or "Khmer bodies with Vietnamese minds. ${ }^{" 380}$ Ethnic Vietnamese in Cambodia were specifically targeted and Cambodians who rejected the CPK were often linked to this group as well. The second group targeted by the Khmer Rouge was any person directly opposed to the implementation of this radical form of Communism. This includes civilians and members of the party who would be purged. The third categories are residents of Cambodia's urban areas. The death rates for urbanities forced to flee towns and cities was considerably higher than those who already resided in rural lands. Finally, the regime murdered anyone who possessed individualistic qualities, like intellectuals, including doctors and professors. These victim categories are not mutually exclusive, nor are they definitive. These are simply the broadest categories of which Khmer Rouge victims can be described.

April 17 marks the official date Cambodian society was fundamentally transformed. All social, economic, religious, cultural, and political relations underwent a radical transformation. In the immediate days after April $17^{\text {th }}$, all cities were evacuated, hospitals were cleared of their patrons, schools sealed, factories closed, money abolished, religious monasteries shuttered and the library system abandoned. ${ }^{381}$ As Jean-Louis Margolin writes, "As with the other mass crimes of the century there is a temptation to seek an ultimate explanation in the madness of one man or in the dazed enthrallment of

\footnotetext{
${ }^{380}$ Kiernan, How Pol Pot Came to Power, p. xi.

${ }^{381}$ Kiernan, Pol Pot Regime, p. 8.
} 
an entire people. ${ }^{382}$ The violence enacted for and by the Khmer Rouge in Democratic Kampuchea to some extent strains credulity. Many have debated whether this episode of state-driven mass death constitutes "genocide" (c.f., Midlarsky 2005; Cook 2009) ${ }^{383}$ It is precisely because of the complexity in Khmer Rouge tactics - direct and indirect means of murder - that I developed the term mass political violence. While mass deportations and political purges occurred simultaneously, their peak effects occurred in different years. Deportations took immediate effect, in terms of execution and their impact on civilian deaths. Having won the civil war and captured Phnom Penh on April 17, the Khmer Rouge claimed evacuations of all cities were a temporary safety precaution to ensure Cambodian lives were spared from possible American bombing campaigns. ${ }^{384}$ Initially, city residents accepted this explanation and largely left of their own volition. They were further enticed by the promise that they would find better sustenance in rural lands. ${ }^{385}$ However, out of the approximate 2-3 million city dwellers who relocated to rural provinces, about 10,000 died - mostly hospital patients, those who were executed by the Khmer Rouge and in some case entire families are reported to have committed suicide. ${ }^{386}$

Although city residents freely abided government orders to evacuate they were prodded to maintain a steady progress. Some deportees attempted to stop during this long

\footnotetext{
${ }^{382}$ Courtois et al., Black Book, p. 615.

383 Midlarsky 2005, The Killing Trap; Susan E. Cook eds., Genocide in Cambodia and Rwanda: New Perspectives, $4^{\text {th }}$ Edition (New Brunswick and London: Transaction Publishers, 2009).

${ }^{384}$ Courtois et al., Black Book, p. 583.

${ }^{385}$ Courtois et al., Black Book, p. 583.

${ }^{386}$ Courtois et al., Black Book, p. 583.
} 
march at monasteries but they were strictly warned against entering by regime soldiers, as these temples were supposed to remain closed. Loung Ung remembers, "Those who didn't listen were shot inside." ${ }^{387}$ Remarkably, within days, between 46 and 54 percent of Cambodia's population were said to be on the move, relocating from all urban areas towards the periphery. ${ }^{388}$ Survival rates primarily depended on two factors. First, if deportees joined relatives in the countryside they often stood a better than average chance of survival. ${ }^{389}$ The second factor that correlates with an increased risk of death from starvation, over-working, malnutrition, or executions, is the number of times a person was relocated after their initial deportation. ${ }^{390}$ The higher this number, the more likely a Cambodian faced certain death. As one can imagine, a mass influx of urbanities to rural villages created dramatic tensions and turmoil. Local conflicts over resources, particularly food, and its consumption drove much of the conflicts in these areas. ${ }^{391}$ As a result, an apartheid system developed with rural villages and "New People"392 living in separate areas of the village and in principle could not talk to one another. ${ }^{393}$ There were several layers to the apartheid system. First, those who had previously lived in the Cambodian countryside were divided into four categories: poor peasants, landed

\footnotetext{
${ }^{387}$ Loung Ung, First They Killed My Father: A Daughter of Cambodia Remembers (New York: Harper Collins Publishers, 2000), p. 28.

${ }^{388}$ Courtois et al., Black Book, p. 583.

${ }^{389}$ Courtois et al., Black Book, p. 584.

${ }^{390}$ Courtois et al., Black Book, p. 585.

${ }^{391}$ Courtois et al., Black Book, p. 584.

392 "New People" is a category used to describe Cambodians from cities and towns, Chinese and Vietnamese that were driven from the urban centers to rural society.

${ }^{393}$ Pin Yathay, Stay Alive, My Son (Ithaca and London: Cornell University Press, 2000), p. 93.
} 
peasants, rich peasants, and former traders. ${ }^{394}$ In the New People, those who were poorly educated and not associated with the former bureaucracy were separated from civil servants and intellectuals. After successive rounds of purges, former civil servants and intellectuals were nearly eradicated and by 1978 , the purges began to target women and children of these two categories. ${ }^{395}$

As mentioned, the second relocation of New People was ordered within a few months on the Khmer Rouge taking power, but this time former city dwellers were not willing participants. ${ }^{396}$ Just in September 1975, several hundred thousand New People were deported from the eastern and southeastern regions and forced toward the northwest territories ${ }^{397}$ Outside the hardship of traversing Cambodia's harsh terrain, "work brigades" were established, which took all young people and parents with no young children far away from their designated villages for months on end. This arduous task led to many deaths. The Khmer Rouge had four intentions when they created these so-called work brigades. First, these work brigades helped separate village peasants and New People, thereby thwarting any possible collaboration between these factions in society. The atomization of society buttressed the regime and diluted individual Cambodian's power. Second, these work brigades introduced New People to the harsh realities of peasant life in the countryside by "proletarianizing" them and dispossessing them of all their worldly possessions. The third motive of the CPK was to control the population and

\footnotetext{
${ }^{394}$ Courtois et al., Black Book, p. 585.

${ }^{395}$ Courtois et al., Black Book, p. 585.

${ }^{396}$ Courtois et al., Black Book, p. 585.

${ }^{397}$ Kiernan, Pol Pot Regime, p. 97.
} 
the nation's agricultural system. This order of mandatory participation in work brigades allowed the regime to achieve both goals in a single policy. Finally, these harsh work conditions rid the Khmer Rouge of "useless mouths" without the need to directly murder or purge unwanted persons from society. ${ }^{398}$ Taken together, this policy demonstrates the regime's power and strategic foresight in eliminating rivals and any person that could cause a problem to the regime without direct bloodshed. Though the Khmer Rouge would not shy away from the latter either.

The Khmer Rouge did allow for "voluntary" transfers to occur rather than forced deportations. By enlarge New People were allowed to "return to their native villages" where they believed working conditions and their overall quality of life would be better. ${ }^{399}$ In many cases many of these volunteers faced harsher conditions in these new areas than was advertised. In a perverse way, any person who came forward as a volunteer "... in effect denounced themselves" and found themselves in "a ploy to weed out people with individualistic tendencies... Anyone who fell into the trap showed that he had not yet got rid of his old-fashioned tendencies and needed to go through a more severe regime of retraining in a village where conditions were even worse."400

When states engage in mass political violence they become principal perpetrators when governments endorse, sanction, or command persons to enact violence, inevitably some individuals in society bandwagon and partake in local acts of violence too. This was the case in Cambodia. "The [very] utterances of Pol Pot motivated people to kill. But

\footnotetext{
${ }^{398}$ Courtois et al., Black Book, p. 585.

${ }^{399}$ Courtois et al., Black Book, p. 585.

${ }^{400}$ Yathay, Stay Alive, My Son, p. 124.
} 
individuals took advantage of the permissive atmosphere of terror to settle old scores and kill as a form of momentary sport." ${ }^{401}$ Most of the victims during the CPK ruling period (1975-79) were from collectivization campaigns or political purges and not from these isolated opportunists' killings. Pol Pot was convinced that collectivization of the country's agricultural system and abandoning all individualistic tendencies would provide Cambodia with economic independence. ${ }^{402}$ The first efforts at collectivization began while the Khmer Rouge was still fighting for control. In 1973, this policy was implemented in regions controlled by the party. ${ }^{403}$

At the beginning, it was relatively easy for the CPK to define who and what they opposed, rather than express any forward looking agenda. According to Pin Yathay, a survivor of Democratic Kampuchea, remembers the Khmer Rouge sought revenge. ${ }^{404}$ They sought a national revenge in the form of revolution. They wanted revenge for rural Cambodia against urbanities. The regime had quickly stripped everything of these New People and leveled the playing field with that of the rural peasantry. Yathay also notes that revenge was personal. Pol Pot and the regime took advantage of the chaos they sowed to eliminate "professional and familial hierarchies" and promoted previously marginalized persons to positions of power (e.g., alcoholics were given positions of authority at the village level). ${ }^{405}$ Within one year, the CPK goal of ridding the population

\footnotetext{
${ }^{401}$ Kissi, Revolution and Genocide, p. 91.

${ }^{402}$ Karl D. Jackson, “The Ideology of Total Revolution,” in Karl D. Jackson, ed., Cambodia: 1975-1978: Rendezvous with Death (Princeton: Princeton University Press, 1989), p. 39-49.

${ }^{403}$ Kiernan, How Pol Pot Came to Power, p. 336-337.

404 Yathay, Stay Alive, My Son, p. 101-103.

405 Yathay, Stay Alive, My Son, p. 101-103.
} 
of former military and governmental officials had been widely achieved and a new government had taken over in the capital.

By the second year of CPK rule, the time came for political purges and pogroms. This strategy would last until the Khmer Rouge was ousted in 1979. When Khmer Rouge loyalists came across anyone or anything that threaten their "preeminence" or legitimacy it was immediately crushed. ${ }^{406}$ Wiped from society. The purge specifically targeted anyone who diverged from Pol Pot or expressed support for neighboring Vietnamese communists. It was clear, communism in Democratic Kampuchea was to be unique and exclusive, overriding all other geo-political ties. By September 1976, key members in the CPK hierarchy - such as Keo Meas, number six - were arrested and purged. ${ }^{407}$ The speed and breath of political purges increased because of a rising sense of mutual suspicion towards one another. This led to many false accusations and finger pointing that would lead to purges all across the country. In 1978, the disintegration of the economy from the governance more difficult. Coupled with initial Vietnamese incursions, Khmer Rouge officials continued their harsh policies and crackdown.

Despite widespread mass political violence, the "really massive genocide took place in the eastern zone." ${ }^{408}$ Many victims in this zone were accused of being Vietnamese sympathizers were often executed for being "Vietnamese in Khmer

\footnotetext{
406 David P. Chandler, Brother Number One: A Political Biography of Pol Pot (Boulder, CO: Westview Press, 1999), p. 205-209.

${ }^{407}$ Courtois et al., Black Book, p. 586.

${ }^{408}$ Courtois et al., Black Book, p. 587.
} 
bodies." ${ }^{409}$ This perceived threat was heightened because of neighboring Vietnam. Clashes with Vietnam begun in 1977 and by January 1979, the two countries were in a full-fledged war. From May and December 1978 the regime murdered between 100,000 and 250,000 people. ${ }^{410}$ To reiterate, the impact of CPK deportations -in tens of thousands of Cambodians were sent on trucks, trains, and boasts from the east to other regions of the country. ${ }^{411}$ Many of these deportees died in transit and those who survived were forced to wear blue clothes - as opposed to everyone else under Pol Pot who were to wear black. ${ }^{412}$ These deportees were systematically targeted and massacred. "In one cooperative in the northwest, when the Vietnamese army finally arrived, only about 100 easterns of the original 3,000 remained." ${ }^{413}$

During the final year of CPK rule, the regime carried out many last minute atrocities - including at the infamous Tuol Sleng, also known as S-21 prison. Throughout CPK rule prisons were called "reeducation centers" and increasingly became difficult to distinguish between "detention centers," which were for hardened criminals, and these now torture centers. ${ }^{414}$ It seems it was decided early on that prisoners were to be executed or suffered a slow-death from disease, malnutrition, and starvation. Similar to the Soviet

\footnotetext{
${ }^{409}$ Courtois et al., Black Book, p. 587.

${ }^{410}$ Courtois et al., Black Book, p. 587.

${ }^{411}$ Courtois et al., Black Book, p. 587.

${ }^{412}$ David P. Chandler, The Tragedy of Cambodian History: Politics, War, and Revolution since 1945 (New Haven and London: Yale University Press, 1991), p. 296-297.

${ }^{413}$ Chandler, Tragedy of Cambodian History, p. 296-297.

${ }^{414}$ Courtois et al., Black Book, p. 582.
} 
Union and China prisoners were often invited to attend "study sessions." 415 The Khmer Rouge's complex prison system was carefully hidden from public view. Haing Ngor writes:

The reality of the prison system was carefully hidden - and this was a mystery that made it more frightening still - some deportees had a reasonable idea of how the system worked, "Perhaps, I thought, there were two parallel systems of punishment: first, a prison system that was part of a bureaucracy that needed to be fed to justify its existence; and second, an informal system that gave the leader of the cooperative freedom to hand out punishments, although the effect of each on the prisoner was ultimately the same. ${ }^{416}$ Because of the CPK's desire to keep the prison system secret, all executions sentences were carried out after night fall. ${ }^{417}$

At Tuol Sleng, the CPK's chief interrogation center, saw about 14,000 men, women, and children come through its doors. ${ }^{418}$ Almost all of them were tortured and executed. ${ }^{419}$ S-21 may be the most notorious "security prison," but there were about 150 others constructed and used during CPK governance. ${ }^{420}$ The level of violence propagated by Khmer Rouge perpetrators in staggering. Despite its intensity, the regime preferred

\footnotetext{
${ }^{415}$ Courtois et al., Black Book, p. 612.

${ }^{416}$ Haing Ngor, Survival in the Killing Fields (London: Macmillan Publishing Company, 1987), p. 228-229.

${ }^{417}$ Courtois et al., Black Book, p. 582.

${ }^{418}$ Chandler, Brother Number One, p. 123.

${ }^{419}$ Chandler, Brother Number One, p. 123.

${ }^{420}$ Henri Locard, "State Violence in Democratic Kampuchea (1975-1979) and Retribution (1979-2004)" European Review of History 12:1 (March 2005), p. 134.
} 
disappearing victims rather than murdering them in the public square. In this case, the terrifying absence of direct violence was itself traumatic to many Cambodians.

\section{Decision Points}

François Ponchaud aptly writes, "Nothing in Democratic Kampuchea seems to happen by chance; on the contrary, everything appears to be planned in advance and executed methodically and with relentless consistency." 421 It is clear the decision points for mass political violence in Democratic Kampuchea were strategic and instrumental calculations to achieve radical transformation of society in preserving the regime's dominance. Just over a month into power, Pol Pot declared eight objectives of the regime:

1. Evacuate people from all towns.

2. Abolish all markets.

3. Abolish Lon Nol regime currency and withhold the revolutionary currency that had been printed.

4. Defrock all Buddhist monks and put them to work growing rice

5. Execute all leaders of the Lon Nol regime beginning with the top leaders

6. Establish high-level cooperatives throughout the country with communal meals.

7. Expel the entire Vietnamese minority population.

8. Dispatch troops to the borders, particularly the Vietnamese border. ${ }^{422}$

\footnotetext{
${ }^{421}$ François Ponchaud, Cambodia Year Zero, trans. by Nancy Amphoux (New York: Holt, Rinehart and Winston, 1977), p. 72.

${ }^{422}$ Kiernan, Pol Pot Regime, p. 55.
} 
It's clear all ruthless actions of the CPK from 1975 to 1979 were an effort to achieve these eight points Pol Pot laid out in May 1975. This meeting of senior military and political leaders in the newly established regime is perhaps the closest we have to a smoking gun.

Pol Pot could not have been more different - in terms of his psyche - than Stalin. Pol Pot never sought to develop a cult of personality. In fact, he valued his secrecy above all else. According to Margolin “...it was only after January 1979 that many Cambodians finally learned who their prime minister had been over the preceding years." 423 This lack in a cult of personality did not prevent him from seeing "enemies everywhere within our ranks, in the center, at headquarters, in the zones, and out in the villages." 424 By October 1975 Pol Pot had decided to consolidate power by eliminating five of the top 13 CPK officials along with many regional secretaries. ${ }^{425}$ As was the case in later years, this initial purge reached all the way down to the grass-roots level with one district seeing about 57 percent of its population killed as "traitors." 426 But, in terms of total deaths stemming from regime policies, the true depravity of the Khmer Rouge "owes its origins in part to the contradiction between the huge ambitions of its leaders as the tremendous obstacles they faced." 427 The decision to radically transform Cambodian society,

\footnotetext{
${ }^{423}$ Courtois et al., Black Book, p. 606.

${ }^{424}$ Chandler, Tragedy of Cambodian History, p. 298.

${ }^{425}$ Courtois et al., Black Book, p. 586.

${ }^{426}$ Kiernan, Pol Pot Regime, p. 144.

${ }^{427}$ Courtois et al., Black Book, p. 617.
} 
seemingly overnight, is the greatest factor that resulted in the slow death of hundreds of thousands of innocent Cambodians.

Finally, who were the perpetrators of Pol Pot's Khmer Rouge? According to many survivors, the overwhelming majority of soldiers were extremely young. ${ }^{428}$ Khmer Rouge systematically employed child soldiers that were twelve years old or younger in many aspects of its reign. This led some to call the regime a "dictatorship of infants." 429 Broadly speaking, the research on the moral development of child soldiers is mixed. Bruce Auster and his co-authors write, "War deforms their [children's] sense of right and wrong, turning twelve-year-olds into cold-blooded killers." ${ }^{430}$ While Elbedour et al. (1997) find participation in violence and armed conflict disproportionately affects boys compared to girls. ${ }^{431}$ On the other hand, Jo Boyden argues that we need to consider "the possibility that images of young former combatants as moral outlaws on the margins of society may be based more in the moral panics of adults than in lived realities." 432 Irrespective of this academic debate on the moral development of child soldiers, it is clear the Khmer Rouge employed these adolescents as soldiers and guards and in many cases they partook in the execution of violence with little resistance.

\footnotetext{
${ }^{428}$ Courtois et al., Black Book, p. 620.

${ }^{429}$ Courtois et al., Black Book, p. 621.

${ }^{430}$ Quoted in Jo Boyden, "The Moral Development of Child Soldiers: What Do Adults Have to Fear?" Peace and Conflict: Journal of Peace Psychology 9:4 (2003), p. 352-353.

${ }^{431}$ Salman Elbedour, Ahmad M. Baker, and William R. Charlesworth, "The impact of political violence on moral reasoning in children," Child Abuse \& Neglect 21:11 (1997), p. 1053.

432 Boyden, "The Moral Development of Child Soldiers," p. 359-360.
} 


\section{$\underline{\text { The Victims }}$}

There is great debate in legal, political, and academic circles on the total number of people killed in Democratic Kampuchea. If we were to take Pol Pot and senior Khmer Rouge officials at their word - and we should not - they claim minimal casualties. In a rare interview in December 1979, Pol Pot claimed that "only a few thousand Cambodians have died as a result of the application of our policy of bringing abundance to the people." ${ }^{433}$ Khiev Samphan, the head of state for Democratic Kampuchea, declared in 1987 that 3,000 people were killed "by mistake," 11,000 were killed because they were "Vietnamese agents," and 30,000 Cambodians were put to death by "Vietnamese agents who had infiltrated the country." $" 434$ Samphan went on to say when Vietnam invaded their soldiers killed about 1.5 million Cambodians in 1979-80; perhaps an inadvertent admission of internal CPK estimates of death tolls. Lon Nol, who led Cambodia until the Khmer Rouge overthrew him in 1975, estimated about 2.5 million perished under Democratic Kampuchea Finally, Pen Sovan, a former secretary general of the People's Revolutionary Party of Kampuchea, which came to power to 1979 has cited Vietnamese propaganda that 3.1 million were killed. ${ }^{435}$ Academic and policy circles are also divided over the death tolls. David Chandler estimates there were 800,000 to 1 million victims. ${ }^{436}$ To the contrary, Michael Vickery, an American historian, puts the figure around

\footnotetext{
${ }^{433}$ Chandler, Brother Number One, p. 265.

${ }^{434}$ Chandler, Brother Number One, p. 322.

${ }^{435}$ Courtois et al., Black Book, p. 589.

${ }^{436}$ Chandler, Brother Number One, p. 261.
} 
750,000. ${ }^{437}$ Both Ben Kiernan and Usha Welaratna independently found that about 1.5 million people died. ${ }^{438}$ Welaratna further calculates that 80 percent of those who perished were men between 20 and 50 years old. ${ }^{439}$ Marek Sliwinski reached 2 million dead or 26 percent of the population. ${ }^{440}$ Finally, a secret CIA study calculated that between 1970 and 1979, about 3.8 million people died from malnutrition or disease and from direct violence. ${ }^{441}$ All told, we may never truly know the extent of Khmer Rouge's devastatingly brutal reign.

When we unpack these national figures there is considerable variation and nuance. As can be expected, the death toll was terribly high among city dwellers who had been deported from Phnom Penh and other urban areas to the periphery. These residents were ill-prepared, ill-advised, and dramatically unqualified for surviving years on end in Cambodia's harsh rural landscape. There were disparities in religious groups. Though 80 percent of Cambodians identified as Buddhist, the worst religious atrocities were experienced among Cambodia's small Catholic population, where about half were killed under the Khmer Rouge. ${ }^{442}$ The CPK also viewed monks with great suspicion. You will recall, one of the CPK's first orders in April 1975 was to forcibly close all monasteries

\footnotetext{
${ }^{437}$ Michael Vickery, Cambodia: 1975-1982 (Boston, MA: South End Press, 1985).

${ }^{438}$ Kiernan, Pol Pot Regime, p. 1-2.

${ }^{439}$ Usha Welaratna, Beyond the Killing Fields: Voices of Nine Cambodian Survivors in America (Stanford, CA: Stanford University Press, 1993), p. 1-2.

${ }^{440}$ Courtois et al., Black Book, p. 589.

${ }^{441}$ Etcheson, Rise and Demise, p. 148.

442 Jean-Louis Margolin quotes Marek Sliwinski, who argues, "Cambodian Catholics were the group that met the worst fate; at least 48.6\% percent of them disappeared." Quoted in Courtois et al., Black Book, p. 593.
} 
and kill any who entered their doors. Because monks had historically played an important role in Cambodian society, they were considered to be a direct threat to the regime's power. Any monk who refused to "defrock [was] systematically eliminated. Nationwide, their number fell from approximately 60,000 to $1,000 . " 443$ Those who were intellectuals, such as doctors, lawyers, or any educated elites were short listed for extermination. ${ }^{44}$ Somaly Lun recalls, "Although all the senior members of the Khmer Rouge were educated abroad in France, anyone else with an education, including much-needed doctors [like her father], was seen as a dangerous class enemy that had to be eliminated." ${ }^{445}$ Her father was sent to heal a senior CPK official and once his task was completed he was summarily executed for being part of this "dangerous" enemy class. Some intellectuals were apparently "allowed to survive if they renounced all pretense to expertise in any field and abandoned attributes such as books and spectacles."446

As a self-proclaimed Communist state, the peasantry was treated markedly better than other designated groups. They were provided with relatively better food and work assignments. There was a minuscule working class that lived in Phnom Penh and other urban areas. These Cambodians were "subjected to extremely harsh discipline. Gradually, poor peasants, who were considered more reliable than workers, replaced workers who

${ }^{443}$ David Hawk, "The Photographic Record,” in Jackson, Cambodia: 1975-1978, p. 212.

${ }^{444}$ George Chigas and Dmitri Mosyakov, "Literacy and Education under the Khmer Rouge," The Cambodian Genocide Program, Yale University, Accessed on March 17, 2018. URL: https://gsp.yale.edu/literacy-andeducation-under-khmer-rouge.

445 Andrew Anthony, "Interview: We'd walk to the field to work and see the bodies. They left them there to scare us," The Guardian, November 14, 2009, Accessed on March 17, 2018. URL: https://www.theguardian.com/world/2009/nov/15/cambodia.

${ }^{446}$ Courtois et al., Black Book, p. 591. 
had been in Phnom Penh before 1975. ${ }^{447}$ Naturally, Khmer soldiers were treated the best. Despite Democratic Kampuchea's utopian goal of equality, Khmer soldiers were first to feast and first to satisfy. Some of the Khmer Rouge's real ire was reserved for ethnic minorities, particularly the Vietnamese. After May 1975, about 150,000

Vietnamese were forcibly deported and repatriated to Vietnam. ${ }^{448}$ This left only a fraction of the initial immigrant population behind, with most of these Vietnamese already being intermarried with Khmer families. With respect to Cambodia's Cham Muslim minorities, they were largely invited to participate in CPK policies because of their reputation as exceptional fighters. ${ }^{449}$ The Cham were generally treated with dignity, though there were punished for being "overly involved in commerce... [and] Cham was now banned as a 'foreign language. ${ }^{\prime 450}$ How did these groups generally fair? The Chinese minority living in Democratic Kampuchea suffered about a 50 percent death rate. ${ }^{451}$ The Vietnamese experienced an even higher proportion of killing. More than four-fifths of former army officers were executed, about 51.5 percent of intellectuals, and about 42 percent of the residents of Phnom Penh were killed. ${ }^{452}$

In Democratic Kampuchea, survival depended on two factors. First, for deportees, survival depended on where one was sent. "Being sent to a wooded or mountainous zone

\footnotetext{
${ }^{447}$ Courtois et al., Black Book, p. 592.

${ }^{448}$ Courtois et al., Black Book, p. 592.

${ }^{449}$ Courtois et al., Black Book, p. 594.

${ }^{450}$ Courtois et al., Black Book, p. 594.

${ }^{451}$ Kiernan, Pol Pot Regime, p. 295.

452 Jean-Louis Margolin quoting Marek Sliwinski, Le genocide Khmer rouge: Une analyze démographique (Paris: L'Harmattan, 1995), p. 30.
} 
or to a region where the main crop was jute was a sentence to almost certain death, since there was very little interregional communication, and supplies rarely arrived." 453 The Khmer Rouge mandated consistent agricultural food production quotas across all zones and regions, regardless of each zone's ability to produce food and supplies. According to Yathay, "In the village of Don Ey, famine was widespread, there were no births at all, and as many as 80 percent of the inhabitants died."454 The second factor was a person's luck. Survival greatly depended on "adopt[ing] a completely new set of rules." However, even an unwavering adoption of Khmer Rouge laws could not guarantee one would not be accused of spying for United States or Soviet espionage agencies (e.g., the CIA or KGB). All that was required for a person to be arrested, was for them to be accused of spying for these agencies three times. ${ }^{456}$ The purge was fueled by the perception that society was filled with enemies of the regime. Elizabeth Becker recounts, "According to Komphot, a banker who escaped the northern zone, 'people were killed one by one - there were no mass killings. The first to go were a dozen New People, people who were suspected of having been soldiers, and so forth. During the first two years about a tenth of them were killed, one by one, together with their children. I don't know how many died in all." 457 If you were fortunate enough to survive deportation from

\footnotetext{
${ }^{453}$ See Michael Vickery, "Democratic Kampuchea: Themes and Variations," in David P. Chandler and Ben Kiernan eds., Revolution and Its Aftermath in Kampuchea: Eights Essays (New Haven: Yale University Southeast Asia Studies Monograph Series No. 25, 1983), p. 99-135; Courtois et al., Black Book, p. 595.

${ }^{454}$ Courtois et al., Black Book, cites Yathay, Stay Alive, My Son, p. 217-264.

${ }^{455}$ Yathay, Stay Alive, My Son, p. 67.

${ }^{456}$ Courtois et al., Black Book, p. 586-587.

${ }^{457}$ Elizabeth Becker, When the War Was Over: Cambodia and the Khmer Rouge Revolution, Revised Edition (New York: Public Affairs, 1998), p. 271.
} 
Cambodia's bountiful lands to its harsh periphery, your ultimate existence greatly depended on the level of suspicion you brought about yourself and your daily activities. Simply put, no one was safe from the state's seemingly erratic ideological persecution. 


\section{CHAPTER V}

\section{STATE-SOCIETY COALITIONS: THE HOLOCAUST AND RWANDA}

"The Moldovans... were the people who helped the Germans, they burned houses and people... The Moldovans were worse than the SS."

- Jewish Survivor ${ }^{458}$

\section{Introduction}

State-society coalitions have been the second of two primary perpetrators of mass political violence since the beginning of the $20^{\text {th }}$ century. I distinguish this perpetrator model from that of state perpetrators - as discussed in the preceding chapter - by the substantial role organized social units play in the implementation of violence against a target population. Table 3.2 in Chapter three best summarizes key differences between all four categories of perpetrators. There are two central commonalities between state perpetrators and state-society coalitions. The first resides in the role of government agents as a leading perpetrators of violence. Under both categories, formal military units or institutionalized paramilitary forces (e.g., the Schutzstaffel or SS) are leading actors in the evolution of violence against a target population. The second commonality between these two categories is that both possess a substantial amount of resources to sustain killing over time. In both these instances, the full weight and resources of government are utilized in the implementation of violence. As such, this aspect, nearly ensures perpetrators retain a high degree of sustained killing capacity - absent exogenous

\footnotetext{
${ }^{458}$ Quoted in Diana Dumitru, The State, Antisemitism, and Collaboration in the Holocaust: The Borderlands of Romania and the Soviet Union (New York: United States Holocaust Memorial Museum and Cambridge University Press, 2016), p. 1.
} 
interventions. Despite these two commonalities, there remains one crucial difference. Under state-led mass political violence episodes, society in the form of organized social units (e.g., militias) is not a threat to the target population. The only societal form of violence that occurs is in vigilantism or bandwagoning onto government violence, so that individuals can settle local grievances. By enlarge society writ large is absent as an active participant. In state-society coalitions, societal actors are not only involved in the development and implementation of violence, but they are explicitly co-perpetrators alongside government forces - hence the name "state-society coalition." State-society coalitions are the second major primary perpetrator in this model of mass political violence.

State-society coalitions are just as common as state-led mass political violence episodes. In this chapter I examine the Nazi genocide against the Jews in Europe during World War II and the genocide against the Tutsi in Rwanda during 1994. ${ }^{459}$ Both of these episodes reflect key characteristics of the state-society coalition model. Despite the exceptionally violent nature of these two episodes, the $20^{\text {th }}$ century is home to other examples, including the Armenian genocide of 1915-1918 in the Ottoman Empire as an example of where a state-society coalition sought a "total domestic genocide," meaning, the destruction of all Armenians and other "foreign" groups within the borders of the Ottoman Empire. ${ }^{460}$ The Indonesian genocide between October 1965 and March 1966 is

\footnotetext{
${ }^{459}$ I explicitly use the term genocide here instead of mass political violence, because of each episode's unequivocal nature. As I discussed in chapter two, genocidal violence can be mass political violence, but not all mass political violence is genocidal. These two cases are archetypal instances of genocide, therefore I used this terminology.

${ }^{460}$ Robert Melson uses the term "total domestic genocide" to distinguish the Armenian total "domestic" genocide from that of the Holocaust, which was a total genocide, that extended beyond Germany's borders.
} 
another example of both substantial societal involvement in the political killings of victims and of vast state and military planning that internal top-secret government documents “describe...as an "Annihilation Operation” (Operasi Penumpasan)."461 Ethiopia between 1976-1979 is yet another example, where the army and state security apparatus joined by civilian "defense" squads slaughtered 10,000 victims. ${ }^{462}$ Finally, from 2003 to 2005, the Sudanese military coordinated its campaign of terror and destruction with Arab militias, the Janjaweed, to expel, starve, and massacre tens of thousands of Fur, Zaghawa, Masaleit, and other non-Arab groups from Sudan's western province Darfur. These are just some of the $20^{\text {th }}$ century's most devastating examples in state-society coalitions enacting mass political violence.

Given the prevalence of state-society coalitions, why choose the Holocaust and the Rwandan genocide in lieu of Darfur or Indonesia? There are four reasons for this particular case selection. The first is, the Holocaust and Rwanda are universally recognized as two of the $20^{\text {th }}$ century's prototypical cases of genocide. In the immediate aftermath of both tragedies the international community uttered the phrase "Never Again." Despite our collective inability to live up to this two-word phrase, the Holocaust and Rwandan genocide represent core case studies in Genocide Studies. My decision to write about Nazi extermination efforts of European Jews and Hutu hard-liners' struggle

\footnotetext{
Robert F. Melson, Revolution and Genocide: On the Origins of the Armenian Genocide and the Holocaust (Chicago and London: The University of Chicago Press, 1992), p. 2.

461 Jess Melvin, The Army and the Indonesian Genocide: Mechanics of Mass Murder (London and New York: Routledge, 2018), p. 1.

${ }^{462}$ Barbara Harff, "No Lessons Learned from the Holocaust? Assessing Risks of Genocide and Political Mass Murder since 1955," American Political Science Review Vol. 97, No. 1 (2003), p. 71.
} 
to annihilate all Tutsi in Rwanda is, in part, based on the severity of these cases and their profound influence on our discipline's understanding of mass political violence. The second justification for using these two cases resides in their vastly different stages in development, yet similar experience in forming a state-society coalition for the purpose of obliterating a victim population. In many ways, Nazi Germany was a development marvel. Richard Evans cutely writes, "The German economy was the most powerful in Europe, German society the most highly developed. Capital enterprise had reached an unprecedented scale and degree of organization..."463 Rwanda on the other hand was in comparatively worse shape. Structural adjustment had bankrupted many state enterprises and contributed to the disruption in the administration of public service. ${ }^{464}$ The economy started to decline in 1986-87 when coffee prices fell from 14 billion to 5 billion Rwanda francs. ${ }^{465}$ Following the decline in revenue, Rwanda's trade deficit soared and its debt began to stack up. ${ }^{466}$ Therefore, Rwanda's economic experience prior to genocide could not have been more different than Nazi Germany's. As such, this case comparison presents a hard test for my model of state-society coalition perpetrators.

The third reason for this case selection stems from the fact that both episodes embody and highlight different aspects of the state-society coalition model. While each case's perpetrators fit squarely within this category, the Holocaust epitomizes the role of

\footnotetext{
${ }^{463}$ Richard J. Evans, The Coming of the Third Reich (New York: The Penguin Press, 2004), p. xxiii.

${ }^{464}$ Michel Chossudousky, The Globalisation of Poverty: Impacts of IMF and World Bank Reforms (London and New Jersey: Zed Books; Penang: Third World Network), p. 116.

${ }^{465}$ Gerard Prunier, The Rwanda Crisis 1959-1994: History of a Genocide (London: Hurst and Company), p. 123.

${ }^{466}$ Helen M. Hintjens, "Explaining the 1994 genocide in Rwanda," The Journal of Modern Africa Studies $37: 2$ (1999), p. 256.
} 
state perpetrators while Rwanda illustrates society's role. This chapter and dissertation is not the end of my analysis but a first step. Future research will expand to include other case studies in mass political violence. This comparative analysis is just a start in this long endeavor.

The remainder of this chapter is divided into four sections. In the next section I describe the dynamic structural approach to state-society coalitions. Section three and four applies this approach to the Holocaust and Rwanda. In the final section I discuss preliminary conclusions of this perpetrator model.

\section{A Dynamic Structural Approach to State-Society Coalitions}

While state perpetrators of mass political violence can emerge at any time irrespective of their probability of success - state-society coalitions require particular conditions for their emergence. Society, in the form of large organized social units (i.e., militias, sub-state factions, mobs, or gangs) must be ready, willing, and able to partake in many of the crimes committed during mass political violence episodes. The societal component of state-society coalitions can be either self-mobilized in the form of "civilian defense squads" or government instigated and sanctioned. The basic argument here, is that societal actors may muster from direct or indirect government actions. Once their units mature, they will become a pseudo-equal partner in the coalition to murder victim populations. The extent they are controlled by government agents greatly depends on their initial formation and its relation to the state security apparatus. Under these circumstances society is largely cooperative to government ideology (e.g., Nazism or Hutu Power) and many of its persons indoctrinated by dehumanization campaigns (e.g., 
antisemitism, Aryanization of Europe, or the Hutu Ten Commandments). As will be shown, ideology and dehumanization programs is one aspect that makes state-society coalitions particularly dangerous for relatively small ethno-religious-national groups in society controlled by another larger socio-political group.

The old adage, "a problem shared is a problem halved" rings true when state and societal perpetrators deem a minority group to pose a threat to their way of life, governing system, or mere existence threatens the very nature of the state. In these cases, when state-society coalitions form they are dispersing the pressures of mass political violence across an array of organizations, thus increasing their likelihood of success by sharing the burden of command. Figure 5.1 presents the model of mass political violence episodes for state-society coalitions.

\section{Figure 5.1: State-Society Coalition Perpetrators}

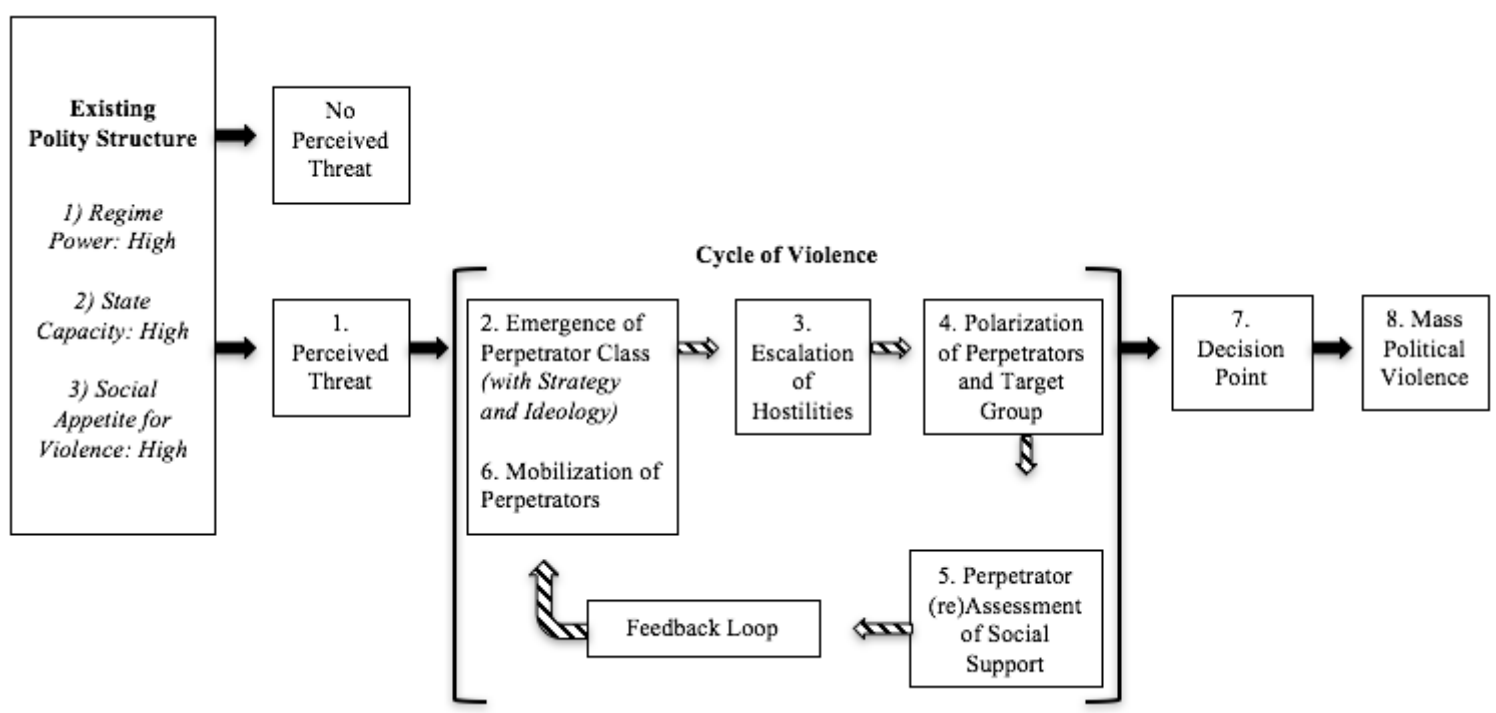

In state-led mass political violence episodes, only a society’s appetite for violence is low. Under state-society coalitions, all three antecedent variables in existing polity structure are rated as "high." These episodes typically have strong charismatic leaders in 
charge of a hierarchical regime that is able to wield personal political power both inside and outside the administrative state. Moreover, the state shares its monopoly over the use of force with approved, vetted organized social units. This dispersed authority to enact violence gives each co-perpetrator wing of the coalition a distributed lethality and sense of ownership over the speed by which violence is pursued. The level of state capacity in these episodes remain strong, as was the case with state perpetrators. The only substantial difference in these three variables is the shared responsibility over the monopoly of force within the state and the presence of a strong, cooperative segment in society that is inclined to partake in mass political violence against an opposing victim group.

Once again the model (Figure 5.1) on the process of mass political violence begins with a question: does any ethno-religious-national groups pose a threat? The logical follow up to this question is, "threat to whom?" In the case of state perpetrators, it is easy to conclude any threats to the government or regime by a domestic group qualifies as sufficient for mobilizing perpetrators. In the instance of state-society coalitions, is the threat perceived by government agents or across society or both? I argue that the government's perception of threat from domestic audiences is the driving factor. This does not mean that threats to the government necessarily exclude those to society. Government after all is composed of individuals from society with specific ideologies, prejudices, stereotypes, animosities, or biases. As will be shown in the following case studies, perceived threats by governments in each se are deemed to affect both the former and society writ large very existence. Once the state-society coalition reacts to a single or collection of threats from target group or groups, the cycle of violence begins, as shown in Figure 5.1. 
Therefore, what types of threats - perceived or otherwise - could unite state organs and armed organized social units to band together against a target population? A full accounting of motivations - as discussed in greater detail in chapter three - is too ponderous of a tangential discussion for this section. That said, we can highlight several of the common culprits cited in the literature. At the macro level, there are two types of threats that require mentioning. The first type of unifying threat comes against the government, where a domestic group threatens the domestic power structure with possible overthrow of state institutions. This can be seen when a minority group attempts to gain access to the levers of power. The second macro threat can stem from widespread political upheavals. ${ }^{467}$ There are many forms of political upheaval, including: an abrupt change in political party politics or even in the redrawing of state boundaries. ${ }^{468}$ Both of these threats to the national government can spur the creation of a state-society coalition.

At the meso and micro levels, there are four central motivations that can be determined as threatening to potential perpetrators. Daniel Chirot and Clark McCauley delineate these four motives in their influential book, Why Not Kill Them All? "Of course the most basic condition for [mass political violence] is that one group has an overwhelming superiority in power. ${ }^{" 469}$ Chirot and McCauley aptly note, such cases of one group possessing immense power over another is far more common in history then

\footnotetext{
${ }^{467}$ Barbara Harff, "No Lessons Learned from the Holocaust? Assessing Risks of Genocide and Political Mass Murder since 1955," American Political Science Review 97:1 (2003), p. 62.

${ }^{468}$ Ibid.

${ }^{469}$ The authors use the term "mass political murder" in their work to describe what I define as mass political violence between groups. See Daniel Chirot and Clark McCauley, Why Not Kill Them All? The Logic and Prevention of Mass Political Murder (Princeton and Oxford: Princeton University Press, 2006), p. 19.
} 
are cases of mass political violence. Therefore, what motives reflect this frequency mismatch? According to Chirot and McCauley, the implementation of mass political violence is derived from: revenge, convenience, simple fear, and fear of pollution. ${ }^{470}$ State-society coalitions may form as a result of these perpetrator motivations. Perpetrators may be incensed by the perceived "treachery" of a domestic group, and as such, seek "revenge" - either retaliatory or preemptively - in the embodiment of mass political violence. For convenience as a motive, perpetrators make a simple calculation. When all else fails, the simplest tactic in the minds of perpetrators throughout history has been to forcibly remove "the problem" group from perpetrator controlled lands. There are many episodes throughout history where perpetrators have turned to mass political violence as a convenient means of vanquishing an oppositional group:

- Julius Caesar ordered many ethnic cleansings of Germanic tribes during his conquest of Gaul in $1^{\text {st }}$ century B.C.E. ${ }^{471}$

- William the Conqueror's “cleansing" of Yorkshire in $11^{\text {th }}$ century England. ${ }^{472}$

- Cherokee removal by U.S. Government agents because the Cherokee and other Indian populations "were inferior human beings who needed to be removed [from lands recently discovered to have gold deposits] for their own protection" in $19^{\text {th }}$ century America. ${ }^{473}$

\footnotetext{
${ }^{470}$ Chirot and McCauley, Why Not Kill Them All? passim.

${ }^{471}$ Chirot and McCauley, Why Not Kill Them All? p. 24.

${ }^{472}$ Chirot and McCauley, Why Not Kill Them All? p. 20.

${ }^{473}$ Chirot and McCauley, Why Not Kill Them All? p. 21.
} 
- Tsarist Russia in the late $19^{\text {th }}$ century waged war on Muslim Circassians because they could not be subdued due to their being "savages" and "bandits." 474

- U.S., Britain, and Soviet bombing of German occupied cities during the Second World War. (The Anglo-American bombing campaign accounts for between 300,000 and 600,000 German civilian fatalities. It is unknown how many died from the Soviet Red Army's shelling and air strikes of cities. ${ }^{475}$ )

The third and fourth motives Chirot and McCauley denote deal with the emotion Fear is an opaque emotion. It can make emotionally strong people quiver with anxiety or drive the weak to act courageous in spite of insurmountable odds. Chirot and McCauley view fear as a motivator in two distinct ways. The first is "simple fear," meaning, one group takes violent action toward another because they fear no action may result in their own annihilation this operationalization of simple fear mirrors our lay understanding. The second perspective is one's "fear of pollution." This understanding of fear comes from one group's view that the very existence of another ethno-religious-national group threatens their very way of life. The Nazi view of Jews and Hutu hard-liners' opinion of

\footnotetext{
${ }^{474}$ Chirot and McCauley, Why Not Kill Them All? p. 23; Walter Richmond, The Circassian Genocide New Brunswick, NJ and London: Rutgers University Press, 2013).

${ }^{475}$ See Michael S. Sherry, The Rise of American Air Power: The Creation of Armageddon (New Haven and London: Yale University Press, 1987), p. 260 for casualty figures.

Randall Hansen quotes from a letter Sir Arthur Harris, Marshal of the Royal Air Force, wrote to the Undersecretary of State, Air Ministry on October 25, 1943: "The aim of our Bomber Force which went to Cassel [a Germany city, also spelled Kassel] on October $22 / 23$ was to wreck the city.... In the course of the proceedings, the Henschel Works and a number of other factories probably got damaged, and this makes the loss to the enemy all the greater. But the fundamental purpose was to knock another great German city out of the war and add it to the growing list of those which are now liabilities and not assets to the enemy from the point of view of morale and production. By obscuring this purpose, we simply rob the whole operation of its point." Quoted in Randall Hansen, Fire and Fury: The Allied Bombing of Germany, 1942-1945 (New York: Nal Caliber, New American Library, 2008), p. 160.
} 
Tutsis are prime examples of this fear - particularly of one that could "pollute" the gene pool of another group.

Taken together, it is difficult to say which - macro, meso, or micro level motivation is "more deadly" than the next. What we can say is that some grievances like “fear of polluting” one's group gene pool is nearly insurmountable than other motivations like convenience or simple fear. Simple fear of one group against another can be addressed in various forms of confidence building measures. But, fear of pollution from the group's very existence, cannot be overcome. This motivation is greatly linked to propaganda and dehumanization campaigns employed against a victim population. Though any modern perpetrator of mass political violence can employ these two tactics, state-society coalitions are much more inclined to pursue these policies. This may be because of the substantial commitment on the part of regime and society to defame, dismiss, disparage, and ultimately erase a target population from the socio-political environment. John Hagan and Wenona Rymond-Richmond explore the origins of racebased ideology and the dehumanization of indigenous groups in Darfur, Sudan. They empirically demonstrate that these pernicious campaigns operate in a dynamic and interactive way: macro-micro-macros processes that continuously reinforce and fuel intergroup enmity. ${ }^{476}$

There has been and can be many tomes written on the use of German National Socialism and Hutu propaganda campaigns. That said, the following case studies will address these topics, but could not perform a comprehensive assessment of each

\footnotetext{
${ }^{476}$ John Hagan and Wenona Rymond-Richmond, "The Collective Dynamics of Racial Dehumanization and Genocidal Victimization in Darfur, American Sociological Review 73 (2008), p. 875-902.
} 
episode's use of propaganda and dehumanization. Simply put there is too much to discuss. The following case studies explore the process of mass political violence from a national level. Additional research is needed to unpack these episodes at lower levels.

As will become apparent by the end of this dissertation, every modern perpetrator ideal type - state actors, state-society coalitions, state-sponsored groups, and non-state actors - employ and rely on an ideology for unifying their principal perpetrators and accomplices in achieving their desired goals and objectives. That said, perhaps statesociety coalitions rely the most on an ideology to maintain cohesion of forces between state and societal perpetrators. It goes without saying, perpetrators in the Soviet Union and Cambodia relied on an all-encompassing ideology - which in both instances sought a radical transformation of the state. I will argue that in fact their use of Communist ideology appears to be the mold that kept perpetrators together. But, in most cases the regime's power was just as important a factor as their ideology. In the Holocaust and Rwanda, ideology served as an essential ordering principal before, during, and presumably after the atrocities finished. Recalling Figures 4.1 and 5.1, for comparison ideological cohesion and dehumanization campaigns were employed by perpetrators for a significantly longer time during state-society coalitions than for state-led mass political violence. The chief reason being, that for society to be a willing partner in mass political violence, the use of ideology and dehumanizing the "other" group took time to imbed itself into the minds of the people. Therefore, the cycle of violence (see Figure 5.1) will take longer for state-society coalitions than state-led mass political violence episodes. What comes next is two case studies in state-society coalition episodes. Nazi Germany and 1994 Rwanda are two extreme examples of how deadly mass political 
violence can be when state and organized social units collude for the purpose of reordering society but eliminating rival groups.

\section{The Holocaust}

"In order for a house to burn down, three things are required. The timber must be dry and combustible, there needs to be a spark that ignites it, and external conditions have to be favorable - not too damp, perhaps some wind.... Hitler's Nazi regime in Germany provided the spark that set off the destruction we now call the Holocaust, and World War II (1939-1945) created a setting conducive to brutality."

- Doris L. Bergen, $2009^{477}$

There are two conceptual distinctions I must make before delving into the details of Nazi genocidal atrocities. The first distinction is in terminology. Generally, the term "Holocaust" is applied to all Nazi genocidal acts in Europe between 1933 and $1945 .{ }^{478}$ The historian Waitman Wade Beorn segregates Nazi and their collaborators actions into two categories. Beorn uses the term "Holocaust" to explicitly reference the systematic marginalization, persecution, and mass murder of European Jews. ${ }^{479} \mathrm{He}$ then employs the phrase "Nazi genocidal project" to discuss all other mass atrocities against the Roma and

\footnotetext{
${ }^{477}$ Doris L. Bergen, War \& Genocide: A Concise History of the Holocaust, Second Edition (New York: Rowman \& Littlefield Publishers, Inc., 2009), p. 1.

${ }^{478}$ Saul S. Friedman, A History of the Holocaust (London and Portland, OR: Vallentine Mitchell, 2004), p. $\mathrm{x}$.

479 Waitman Wade Beorn, "The crimes of the Wehrmacht and the Alt Right in American Reenacting," (presentation, Florida International University, Miami, FL, February 16, 2017).
} 
Sinti peoples, the mentally and physically handicapped, homosexuals, political opponents, prisoners of war, and Jehovah's Witnesses. ${ }^{480}$ It is clear from the historical record that European Jews experienced explicit and the most severe horrors of any group described above. The breadth and depth of planning that went into their systematic extermination surpasses all other targeted groups. It is for this reason that I accept and follow Beorn's conceptual distinction. That said, both categories are included in my conception of mass political violence. Therefore, when I use this term in the case study I am referencing both of Beorn's concepts of extreme violence. Where analysis permits, I will employ his refined categories for clarity.

The second distinction is the determination of the dates for describing the Nazi efforts to implement mass political violence. Many scholars and organization begin analysis of the Holocaust in January 1933, when the Nazi party came to power. Perhaps most notably by the United States Holocaust Memorial Museum. There is good reason to begin the analysis here. Principally because, soon after obtaining political power, the Nazis moved to end democratic rule in Germany. ${ }^{481}$ Moreover, within two months the first concentration camp opens at Dachau, Germany - it was used to house political opponents of the regime. ${ }^{482}$ There is a difference between concentration camps and killing centers. By 1945 there were only six killing centers, but these six were responsible

\footnotetext{
${ }^{480}$ The Holocaust: A Historical Summary (Washington, D.C.: U.S. Holocaust Memorial Museum, 1997), p. 1.

${ }^{481}$ Adolf Hitler became chancellor of Germany on January 30, 1933. Within two months Nazi s passed "The Enabling Act" which suspended "individual civil liberties and freedom of the press, speech, and assembly, giving Hitler absolute power." See Eve Nussebaum Soumerai and Carol D. Schultz, Daily Life During the Holocaust (Westport, CT and London: Greenwood Press, 1998), p. xvii.

${ }^{482}$ The Holocaust, p. 25.
} 
for millions of murders. ${ }^{483}$ Though legal, political, and "safety" restrictions were placed upon the Jews in 1933, most of the killing began after the Nazi invasion of Poland in 1939. This delay in mass murder has led to some scholars in Political Science to begin analysis here. ${ }^{484}$ Because I am concerned with state-society relations before, during, and after societies in the midst of mass political violence, I will discuss the entire time period between 1993 and 1945. I will note, that from 1933 to 1939 as a preparation for war phase and 1939 to 1945 as the implementation of war period for the purpose of clarification. Though this debate seems arcane, it is important to acknowledge the differences within Holocaust and Genocide Studies.

\section{Existing Polity Structure}

When the Nazi party came to power in 1933, Germany, had only been a "united nation-state" for little over 60 years. Beth Griech-Polelle writes, "for many historians, the lateness of German unification led to an identity crisis. What did it mean to be "a German," who belonged in the Second Reich [Imperial Germany, January 1871]?"485 Antisemtism played a powerful role in answering the question "who belonged and who did not" in a unified German nation-state. "Modern German anti-Semitism was the bastard child of Christian anti-Semitism with German nationalism." ${ }^{486}$ Beginning in the

\footnotetext{
${ }^{483}$ The Holocaust, p. 25.

${ }^{484}$ See Valentino, Final Solutions.

485 Beth A. Griech-Polelle, Anti-Semitism and the Holocaust: Language, Rhetoric and the Traditions of Hatred (London: Bloomsbury, 2017), p. 39-40.

${ }^{486}$ Lucy S. Dawidowicz, The war against the Jews, 1933-1945 (New York: Bantam, 1975, p. 23.
} 
1920s and persisting for decades after Adolf Hitler's death, rumors circulated about his so-called "Jewish blood" as one possible reason for Nazi enmity toward the Jews. This claim that Hitler possessed Jewish heritage is false. ${ }^{487}$ According to legend, because Hitler did not know his paternal grandfather, rumors circulated that he may have been of Jewish ancestry. Doris Bergen summarizes these falsehoods for us:

Those allegations were unfounded, in fact there were no Jews in the town where Hitler's grandmother lived, because Jews were prohibited from living in that part of Austria at the time. Nor are the rumors that Hitler was secretly homosexual or that he had only one testicle. (Both of those common allegations, to the best of anyone's knowledge, are false as well). Such claims reflect a desire to find easy explanations for historical processes that in fact have many complicated causes. ${ }^{488}$ For mass political violence to occur on a scale such as the Holocaust and other Nazi genocidal projects, Germans and their conquered peoples had to accept that certain members of their community as "enemies" that needed vanquishing so that the righteous German Third Reich could survive and thrive. ${ }^{489}$

The Nazi party and its subsequent regime was an incredibly strong, energetic, authoritative, force able to accomplish - in many instances - unthinkable deeds (both in their mobilization capabilities and in future atrocities). There are many direct and indirect preconditions that led to the rise of the Nazi party. Antisemitism, racism, xenophobia, a desire for strong nationalist pride after Germany's defeat in the First World War can all

\footnotetext{
${ }^{487}$ Bergen, War \& Genocide, p. 31.

${ }^{488}$ Bergen, War \& Genocide, p. 31-32.

${ }^{489}$ Bergen, War \& Genocide, p. 1.
} 
explaining, in part, the temptation and rise of National Socialism in the 1920s and 1930 s. ${ }^{490}$ One reason the Nazi party became a dictatorial force was due to Hitler's preoccupation with total loyalty. ${ }^{491}$ One way Hitler achieved total loyalty was to award trusted subordinates with more power, and privileges than their compatriots. ${ }^{492}$ At the same time, if any individuals grew too powerful in the Nazi party, "he [Hitler] found ways to clip their wings, even if it meant temporarily weakening the Nazi party's base of support." ${ }^{493}$ This desire for unwavering commitment led to the "Führer principle," derived from a German term "der Führer" that means "the leader." 494 The Führer principle meant all person must possess resolute commitment to Hitler's incontestable leadership. After this principle had been implemented, Hitler need not issue specific orders to subordinates. According to Bergen, "In the words of one Nazi functionary: "It is the duty of every single person to attempt, in the spirit of the Führer, to work towards him. ${ }^{4495}$ As long as Hitler's wishes were known, no specific orders were necessary. Subordinates would take it upon themselves to implement such wishes into public policy. This benign leadership style would have devastating outcomes during the Holocaust.

Hitler's centralization of power began in the Nazi party and quickly spread to all levers of the German state after 1933. Next to Hitler, Heinrich Himmler would become

\footnotetext{
${ }^{490}$ Bergen, War \& Genocide, p. 1.

${ }^{491}$ Bergen, War \& Genocide, p. 39.

${ }^{492}$ Bergen, War \& Genocide, p. 39.

${ }^{493}$ Bergen, War \& Genocide, p. 39.

${ }^{494}$ Bergen, War \& Genocide, p. 39.

${ }^{495}$ Bergen, War \& Genocide, p. 40.
} 
the second most powerful man in Germany. Himmler was the head of the Schutzstaffel (SS) from 1929 to 1945; and by 1936 he was also the head of all German police organizations. ${ }^{496}$ Richard Breitman called Himmler the "architect of genocide." 497 The regime's power was further bolstered by Reinhard Heydrich who was chief of the Gestapo, a secret German intelligence service. ${ }^{498}$ Himmler's tens of thousands of SS commandos were instrumental in achieving mass political violence. The SS reported directly to the Nazi party and was a check on the official institutions of the German state. The loyalty of SS troops became so powerful that Hannah Arendt would later refer to this dichotomy as the "dual authority." ${ }^{499}$ Hitler's efforts to centralize power received an unexpected boost in 1934. In August, President Hindenburg, the same who had appointed Hitler to the position of chancellor, died. ${ }^{500}$ In light of this unexpected event, Hitler seized the opportunity and combined both offices - the presidency and chancellery - into one under his own leadership. Beyond ceremonial distinctions, there were tangible consequences to this power grab. "According to the German constitution, still officially in force, the president was the supreme commander of the German armed forces." Having combined both positions, Hitler subsequently mandated that all members of the

\footnotetext{
${ }^{496}$ Bergen, War \& Genocide, p. 42.

497 Richard Breitman, The Architect of Genocide: Himmler and the Final Solution (The Tauber Institute Series for the Study of European Jewry, Brandeis, 1992), passim.

${ }^{498}$ Bergen, War \& Genocide, p. 70.

499 The term "dual authority" refers to the dichotomy of power in totalitarian states. Power resides in the Party and in the State. Hannah Arendt, The Origins of Totalitarianism (New York: Harcourt Brace Jovanovich Inc., 1973), p. 395.

${ }^{500}$ Bergen, War \& Genocide, p. 70

${ }^{501}$ Bergen, War \& Genocide, p. 71.
} 
armed forces swear an oath of personal allegiance to him. ${ }^{502}$ All of these actions were buttressed by a 1933 law called "The Malicious Practices Act," that "banned remarks that offended or subverted Nazi authority." ${ }^{503}$ Fear of prosecution under this law led to what some called the "German glance," a quick turn of the head to check for prying eyes before a conversation. ${ }^{504}$ This is yet another sign of the regime's growing power.

In recalling the hierarchy of perpetrators in chapter three (see Figure 3.1), we can observe a clear chain of command. Many, if not most of the perpetrators were true believers in Hitler and Nazism. This is supported by the fact that Germans were not forced to partake in mass political violence. "Those who refused to participate were given other assignments or transferred. To this day no one has ever found a single example of a German who was executed for refusing to take part in the killing of Jews or other civilians..." ${ }^{505}$ Momentarily setting aside the role antisemitism played in fueling perpetrators to kill, some perpetrators simply took it upon themselves - as part of the Führer principle - to seek new ways of enacting Hitler's wishes. Adolf Eichmann is one such example where (perhaps) careerism played the deciding role in his motivations for enacting draconian policies against the Jews. Eichmann led the Central Office for Jewish Emigration in Vienna and later directed the Reich-wide Central Office. ${ }^{506}$ Eichmann was

\footnotetext{
502 Bergen, War \& Genocide, p. 71.

${ }^{503}$ Bergen, War \& Genocide, p. 74.

${ }^{504}$ Bergen, War \& Genocide, p. 75.

${ }^{505}$ Bergen, War \& Genocide, p. 158-159.

506 "Adolf Eichmann," United States Holocaust Memorial Museum Online, accessed April 17, 2018. URL: https://www.ushmm.org/wlc/en/article.php?ModuleId=10007412.
} 
an ambitious mid-level bureaucrat who took it upon himself in 1939 - with no formal authorization - to "facilitate" the mass deportation of Jews from Vienna to the General Government territory, even though no perpetrators had been made on the receiving end for how to handle these Jewish deportees. ${ }^{507}$ Eichmann's 1939 project led to his advancement with the Nazi bureaucracy and thus provided other German officials with a template for promotion. In essence, German officials could not do wrong, insofar as they took their own initiatives against people that the Nazi regime deemed to be inferior.

Turning to state capacity, it is self-evident to any reader of Holocaust literature that the Nazi government possessed an incredible amount of power to exercise control “over persons, activities, and resources within their government's jurisdiction."

Eichmann's ability to mobilize resources on his own for the purpose of the mass deportation of Jews in 1939 is one example of Nazi state capacity. The second is the Nazi's ability to coerce Jews in German occupied territories to dwell in overpopulated ghettos. The Germans established at least 1,000 ghettos in Germany, Poland and other occupied Soviet territories alone. ${ }^{508}$ The ghettoization of Jews in 1939-1940 were deemed a temporary measure for handling the logistics and fate of European Jews. ${ }^{509}$

\footnotetext{
${ }^{507}$ Bergen, War \& Genocide, p. 108.

508 There were three types of ghettos the Germans used. The first was "closed ghettos," where the entire area was closed off by fences, walls and/or barbed wire. The second was an "open ghetto," where there was no clear walled compound but nevertheless "residents" had restrictions for entering and leaving. Finally, there were "destruction ghettos," that maintained the highest security measures of all three variants. These were "tightly sealed off and existed for between two and six weeks before the Germans and their collaborators deported or shot the Jewish population concentration in them." These were particularly common in Lithuania and the Ukraine after German troops conquered these lands from Soviet troops. See "Types of Ghettos," United States Holocaust Memorial Museum Online, accessed April 7, 2018. URL: https://www.ushmm.org/wlc/en/article.php?ModuleId=10007445.
}

${ }^{509}$ Bergen, War \& Genocide, p. 111. 
The third and most destructive example of German state capacity was the concentration camp system and its killing centers. These two versions of camps "were an integral component of Nazi Germany's governing system and a tool for achieving its political aims." ${ }^{, 510}$ The Nazis did not invent nor "pioneer" the concentration camps system. ${ }^{511}$ The first German concentration camps were built in German Southwest Africa (modern day Namibia) on December 11, $1904 .^{512}$ Similar to Nazi actions during World War II, German colonial concentration camps were divided into two categories: those that were designed for the purpose to kill and camps where prisoners were forced to work in harsh, malnourished conditions that often led to death. ${ }^{513}$ The German colonial policy of Vernichtung, or annihilation against the Herero in Southwest Africa, provided the Nazis with mechanical (i.e., the concentration camp system) and public policy (i.e., Vernichtung) precedent in dealing with the Jews and other "inferior" groups. ${ }^{514}$ This is demonstrated by the Third Reich's camps at Buchenwald and Dachau are loosely based on the Second Reich's colonial work camps in Namibia. ${ }^{515}$ In total, between 1933 and 1945 the Nazis and their collaborators set up more than 40,000 camps, prisons, and other

\footnotetext{
510 Yitzhak Arad, Belzec, Sobibor, Treblinka: The Operation Reinhard Death Camps (Bloomington and Indianapolis: Indiana University Press, 1999), p. vii.

${ }^{511}$ Benjamin Madley, "From Africa to Auschwitz: How German South West Africa Incubated Ideas and Methods Adopted and Developed by the Nazis in Eastern Europe," European History Quarterly Vol. 35, Iss. 3 (2005), p. 446.

${ }^{512}$ Madley, "From Africa to Auschwitz," p. 432.

${ }^{513}$ Madley, "From Africa to Auschwitz,” p. 446.

${ }^{514}$ Madley, "From Africa to Auschwitz," p. 430.

${ }^{515}$ Madley, “From Africa to Auschwitz,” p. 446.
} 
"incarceration sites." ${ }^{516}$ This striking statistic alone, reflects the strength of Nazi regime power and state capacity.

Another is, Operation Reinhard, the codename for the Nazi plan to exterminate all Jews in Poland - provides a snapshot of the regime's ability to organize and mobilize mass numbers of people. ${ }^{517}$ Under Operation Reinhard over 2.2 million Jews who resided in hundreds of ghettos were rounded up and transported via the railway system to the death camps. ${ }^{518}$ Unlike Eichmann's experiment of 1939, Operation Reinhard (1941-1943) required coordination between SS authorities and civilian staff at the destinations to prepare for sudden mass arrivals of the Jews. ${ }^{519}$ Despite the railway system being heavily burdened by military logistics at the time, SS authorities were able to coordinate train times, the massive number of freight cars required, and timetables for travel and their supplies in an orderly manner. ${ }^{520}$ All of which supports the regime's strong state capacity.

The sheer amount of German manpower is another strong indication of the Nazi regime's power and state capacity. The SS (protective squads and the Nazis private army) were a quintessential part of Hitler's ability to enforce edicts and achieve total control within the so-called thousand-year Reich. In the months and years after Hitler

\footnotetext{
516 "Nazi Camps," United States Holocaust Memorial Museum, accessed on April 7, 2018. URL: https://www.ushmm.org/wlc/en/article.php?ModuleId=10005144.

517 “Operation Reinhard (Einsatz Reinhard)," United States Holocaust Memorial Museum Online, accessed April 17, 2018. URL: https://www.ushmm.org/wlc/en/article.php?ModuleId=10005195.

${ }^{518}$ Yitzhak Arad, Belzec, Sobibor, Treblinka, p. 44.

${ }^{519}$ Yitzhak Arad, Belzec, Sobibor, Treblinka, p. 44; “Operation Reinhard (Einsatz Reinhard)," United States Holocaust Memorial Museum Online.

${ }^{520}$ Yitzhak Arad, Belzec, Sobibor, Treblinka, p. 49-51.
} 
consolidated power, the SA and Gestapo went door-to-door looking for Hitler's opponents and rivals. ${ }^{521}$ These units were so successful in their mission that the SS and SA established temporary "camps" in warehouses, factories, and other abandoned buildings to house all of Hitler's political enemies. ${ }^{522}$ Despite the overwhelming success of these organizations in enforcing Hitler's will upon German society, the "best" example of German power lay ahead. After the invasion of Poland in 1939, and the Soviet Union in 1941, Hitler formed special units called Einsatzgruppen, or mobilize killing units. ${ }^{523}$ There were four Einsatzgruppen, containing a total of 16 command nits with approximately 3,000 men. ${ }^{524}$ Wherever the Einsatzgruppen went, they carried out the systematic murder of Jewish civilians. ${ }^{525}$ Despite their relatively small size (i.e., 3,000 personnel) the Einsatzgruppen murdered more than 1.5 million Jews before the death camps and their gas chambers opened. ${ }^{526}$ A catholic priest, Father Patrick Desbois, would subsequently call this the "holocaust of bullets." 527

521 "SS Police State," United States Holocaust Memorial Museum, accessed on April 7, 2018. URL: https://www.ushmm.org/outreach/en/article.php?ModuleId=10007675.

522 "SS Police State," United States Holocaust Memorial Museum, accessed on April 7, 2018. URL: https://www.ushmm.org/outreach/en/article.php?ModuleId=10007675.

523 “Einsatzgruppen (Mobile Killing Units)," United States Holocaust Memorial Museum, accessed on April 18, 2018. URL: https://www.ushmm.org/wlc/en/article.php?ModuleId=10005130.

${ }^{524}$ Griech-Polelle, Anti-Semitism and the Holocaust, p. 177, 260; Raul Hilberg, The Destruction of the European Jews (Chicago: Quadrangle, 1967), p. 188-190.

525 The Einsatzgruppen received 20,000 reinforcements from the Ordnungspolizei (known as "Orpo," the order police). Yehoshua Buchlen writes, "there is no thorough research on the role of Orpo in the murder of the Jews. On the structure of Orpo and its general functions in occupied areas of the Soviet Union." See Yehoshua Buchler, "Kommandostab Reichsführer-SS: Himmler's Personal Murder Brigades in 1941" Holocaust and Genocide Studies Vol. 1., No. 1 (1986), pp. 11-25.

${ }^{526}$ Waitman Wade Beorn, "The crimes of the Wehrmacht and the Alt Right in American Reenacting," (presentation, Florida International University, Miami, FL, February 16, 2017).

${ }^{527}$ Beorn, Marching into Darkness, p. 4. 
As raised earlier, the crucial aspect that differs in state-society coalitions from mass political violence episodes that are solely state-led, is the role of organized social units in the preparation and evolution of violence against a victim population. Jared Diamond writes, "It is safe to assume that few people would willingly identify themselves as potential mass murderers or ethnic cleansers... [And we would like to believe that nice people don't] "Commit genocide, only Nazis do." ${ }^{528}$ Unfortunately, the Holocaust is one example where Nazis and German civilians worked together in exterminating targeted populations. The opportunities for civilian participation in violence greatly varied by War Theater, region, country, and locality. Diana Dumitru quotes a Jewish survivor as saying, "Ukrainians were extraordinary people... [They] helped me to survive in the camp," while another Jewish survivor told Dumitru "The Moldovans were worse than the SS." 529 Civilian participation was vastly different across Europe. In some areas, such as Poland, the German forces (Einsatzgruppen, SS, Wehrmacht, and their allies) relied on Polish police units, railroad personnel redeployed as guard to temporary ghettos and ensured an uninterrupted process of deportations that took many Jews to the killing centers. ${ }^{530}$

\footnotetext{
528 Jared Diamond, The Third Chimpanzee (New York: Harper Perennial, 1992), p. 277.

529 Diana Dumitru, The State, Antisemitism, and Collaboration in the Holocaust: The Borderlands of Romania and the Soviet Union (New York: United States Holocaust Memorial Museum and Cambridge University Press, 2016), p. 1.

530 "Press Releases: Collaboration and Complicity during the Holocaust," United State Holocaust Memorial Museum, issued on May 1, 2015, accessed on April 19, 2018. URL: https://www.ushmm.org/information/press/press-releases/collaboration-and-complicity-during-theholocaust.
} 
Civilian participation - in the state-society coalition - varied as well. In some areas individual Poles identified, denounced, blackmailed or chased down Jews who were in hiding. ${ }^{531}$ Other collaborators, particularly those who lived in small towns in eastern Poland actively participated in pogroms and mass murder of their own Jewish neighbors. The pogrom in the town of Jedwabne in 1941 is a well-documented case. Steve Hendrix writes about this mass murder:

In the summer of 1941, the small Eastern village of Jedwabne was occupied, as was all of Poland, by a contingent of German police. On a blistering July day, a group of Polish men from in and around the town began rounding up Jewish male residents. The Jews, led by the local rabbi were forced to pull down a statue of Lenin ${ }^{532}$ that was left over from the soviet occupation of the region. Then, with the Germans looking on, they were taken to a barn and clubbed and stabbed to death by their fellow townsmen... The carnage didn't end there. The raids widened as the day wore on. More and more Jews of both sexes and all ages were packed in the barn. With a crowd of townspeople and German police looking on, the structure was set alight. The next morning a grisly pile of burned and asphyxiated corpses lay amid the smoldering ruins. ${ }^{533}$

\footnotetext{
531 "Press Releases: Collaboration and Complicity during the Holocaust," USHMM, issued May 1, 2015.

${ }^{532}$ Hitler viewed Bolshevism and Judaism as equivalents in evil. He believed "Communist ideology was a Jewish weapon for seizing control of the world." Thus the symbolic - albeit misguided and false significance of forcing local Jews to destroy a statue of Lenin before they too suffered the same fate. See Dumitru, The State, Antisemitism, and Collaboration in the Holocaust, p. 29.

${ }^{533}$ Steve Hendrix, "Poland wants to outlaw blaming Poles for Nazi atrocities. But what about the Jedwabne massacre?" The Washington Post, February 6, 2018, accessed on April 12, 2018. URL: https://www.washingtonpost.com/news/retropolis/wp/2018/02/06/poland-wants-to-outlaw-blaming-polesfor-nazi-atrocities-but-what-about-the-jedwabne-massacre/?noredirect=on\&utm term $=. \mathrm{a} 8 \mathrm{fc} 946 \mathrm{~b} 203 \mathrm{c}$.
} 
The Jedwabne massacre shows how organized social units took it upon themselves in certain localities to prosecute Jews for their "crimes." Their punishment was almost always death. These organized social units worked in conjunction with, sometimes in support of Nazi agents, and sometimes in parallel to them. Nonetheless these two halves of the state-society coalition continued to work toward a unifying goal that being the total extermination of European Jewry.

\section{The "Ordinary Men" or "Willing Executioners" Debate}

At this point in discussing civilian participation in Nazi mass political violence, we reach a hotly contested and occasionally "harsh and bitter" debate over whether civilian participants were "ordinary men" or "willing executioners." 534 Up until this point I have used the term "civilian participation" in lieu of associating my research with one of these scholarly camps. It would be helpful to summarize key questions in this debate before I situate my research within the field.

The first question is, why might otherwise "ordinary" human beings condone, engage, or participate in extraordinary, devious, or reprehensible behaviors as the Holocaust and other Nazi genocidal atrocities? I use the word ordinary in this instance to reference people who are not clinically defined as sadists. It is easy to blame the actions of all perpetrators as crimes only committed by persons who are psychologically predisposed to violence. It is much harder - as an individual reflecting on his/her own actions or as a society - to come to grips with the reality that most perpetrators of mass

\footnotetext{
${ }^{534}$ Daniel J. Goldhagen, Christopher R. Browning, Leon Wieseltier, and Michael Berenbaum, "The "Willing Executioners" / "Ordinary Men" Debate," Selections from the Symposium, United State Holocaust Memorial Museum, April 8, 1996, p. i.
} 
political violence are "ordinary" in this psycho-social sense. Roy F. Baumeister writes, specifically within perpetrator groups that, "the sadists are typically a fairly small number, such as 5 or $6 \%{ }^{, 535}$ This figure is based on a theoretical model of sadistic pleasure applied to perpetrator experiences. Christopher Browning's seminal work Ordinary Men notes various accounts of perpetrators in German Reserve Police Battalion 101 (men who partook in cold-blooded murder of Jews in Poland) that its men reported higher anxiety, "night mares," "gastrointestinal distress," and other negative reactions to killing were common at first. Thus these men (at least initially) were not sadists, they experienced various negative physical-psychological repercussions to their heinous actions. This distraction between sadists and ordinary people is crucial. Neither category excuses the actions of individuals, nor lessens their legal, moral, and human responsibility, but it sheds light into how willing people are to commit such atrocities.

This distinction produces a second question, were perpetrators in Nazi Germany “ordinary men" or part of "Hitler's willing executioners?" This question has spurred fierce debates within Political Science, History, and Holocaust Studies writ large. The two central belligerents in this controversy are Christopher Browning and Daniel Goldhagen. To understand Browning and Goldhagen's arguments we must explore competing theories on the role of antisemitism in pre-war Germany. This debate has renewed interest in establishing antisemitism as either a "deep underlying cause of the evitable Nazi genocide of the Jews and as a specific motivating factor among the

\footnotetext{
${ }^{535}$ Roy F. Baumeister, "The Holocaust and the Four Roots of Evil," in Leonard S. New man and Ralph Erber eds., Understanding Genocide: The Social Psychology of the Holocaust (Oxford and New York: Oxford University Press, 2002), p. 254.
} 
perpetrators." 536 Bergen writes, "Hitler and the Nazis did not invent antisemitism - hatred of Jews - nor were they the first to attack Sinti and Roma (Gypsies) or people considered handicapped. Their hostilities toward Europeans of African descent, Slavic people, Jehovah's Witnesses, and homosexuals were not new either. The Nazis were extremists in the lengths to which they went in their assaults, but they were quite typical in whom they attacked. ${ }^{537}$ Despite some scholar's unwavering assertion that antisemitism played a critical role in Nazi policies (see Lucy Dawidowicz, The War Against Jews, 1933-1945), it was commonplace until the 1970 s to interpret antisemitism as "merely a consequence of more profound socio-cultural and political developments" like fascism and totalitarianism. ${ }^{538}$ Following these two schools of thought, scholars emphasized structural factors like economic hardship, Hitler's personality and charisma, popular support for a project of "national salvation" after Germany's defeat in World War I, the role of bureaucracy in the evolution of violence, and rationalization of perpetrator motives. ${ }^{539}$

It wasn't until Goldhagen's critically acclaimed book Hitler's Willing Executioners that antisemtism was placed as a "monocausal explanation of the Holocaust." $" 540$ The scholarly debate over Goldhagen's thesis has garnered extraordinary

\footnotetext{
536 Omer Bartov eds., The Holocaust: Origins, Implementation, Aftermath (London and New York: Routledge, 2000), p. 2.

${ }^{537}$ Bergen, War \& Genocide, p. 1-2 (emphasis added).

${ }^{538}$ Bartov, The Holocaust, p. 2.

539 Bartov, The Holocaust, p. 2; Ian Kershaw, "Hitler and the Uniqueness of Nazism," Journal of Contemporary History Vol. 39, No. 2 (2004), p. 239-254.

${ }^{540}$ Daniel J. Goldhagen, Hitler's Willing Executioners: Ordinary Germans and the Final Solution (New York: Knopf, 1996), p. 416.
} 
attention in recent years that there is no point in summarizing his argument at length here. Goldhagen persuasively argues with great detail that modern German antisemitism was the fundamental cause of the Holocaust. According to Goldhagen:

That their [perpetrators] approval derived in the main from their own conception of Jews is all but certain, for no other source of motivation can plausibly account for their actions. This means that had they not been antisemites, and antisemites of a particular kind, then they would not have taken part in the extermination, and Hitler's campaign against the Jews would have unfolded substantially differently from how it did. The perpetrators' antisemitism, and hence their motivation to kill, was, furthermore, not derived from some other non-ideational source. It was not an intervening variable, but an independent one. It is not reducible to any other factor. ${ }^{541}$

Leon Wieseltier remarked - at a passionate and at times bitterly worded symposium hosted by the U.S. Holocaust Memorial Museum - "After Goldhagen, the causal relation between ideas and genocide will be impossible to deny." ${ }^{242}$ In Europe, the Jews have consistently faced hostile political and socio-cultural environments according to Goldhagen, throughout their tenure in Germany, Jews were perceived as a "foreign entity." This intergroup enmity of "traditional" antisemtism eventually merged with modern German ideas of nationalism and racial superiority. It was this aligning of idea that Goldhagen claims formed the basis of German "eliminationist antisemitism," that being a mind-set, ideology, or temperament that tended towards exterminating European

\footnotetext{
${ }^{541}$ Goldhagen, Hitler's Willing Executioners, p. 416.

${ }^{542}$ Goldhagen et al., "The Willing Executioners / Ordinary Men Debate,” p. 32.
} 
Jews. It was only after the collective demise of European Jewry that "true" Germans could survive and thrive as a "superior" race. Goldhagen goes on to note that when German perpetrators killed Jews, the vast majority did so with "gusto", enjoyment and "fun", and they "killed for pleasure." 543

Critics of Goldhagen argue that his thesis discounts and downplays the bureaucratic nature of the Holocaust and the diversity of attitudes in German society towards the Jews. Not all Germans - his critics argue - possessed this extreme version of antisemitism. We tangentially see this contention in the intentionalist-functionalist debate over how the German state initially treated the Jews (prior to their full extermination). Goldhagen's assertion that eliminationist antisemitism was the motivation and calling of all "ordinary Germans" and not just Nazi perpetrators has stirred much controversy in academia and German society. Raul Hilberg, a staunch opponent, has declared Goldhagen's work as "simply a bad book" and "worthless." ${ }^{444}$ Hilberg is generally referenced as one of the first historians to emphasize the "bureaucratic aspects of modern genocide. ${ }^{545}$ In contrast to Goldhagen, Hilberg is criticized for undervaluing the impact of antisemitism on the evolution of the Holocaust. In The Destruction of the European Jews, Hilberg narrates anti-Jewish policies from fourth century Rome to modern Germany. He catalogues enmity toward the Jews, hostilities, and period violent episodes.

\footnotetext{
${ }^{543}$ Goldhagen, Hitler's Willing Executioners, p. 241, 231, 451 respectively.

${ }^{544}$ Hilberg wrote these comments in an open letter to Eberhard Jäckel, cited in Geoff Eley, ed., The "Goldhagen Effect": History, Memory, Nazism-Facing the German Past (Ann Arbor: The University of Michigan Press, 2003). 44.

${ }^{545}$ Bartov, The Holocaust, p. 3.
} 
His work argues that the Nazi policy of extermination was "a direct continuation (although not an inevitable outcome) of a long-term European antisemtism." 546 Hilberg highlights for the reader how Nazis - similar to the concentration camp system - did not invent but borrowed from past antisemitism policies, they merely refined and brought the full weight of the German bureaucratic state to bear in the genocide. ${ }^{547}$

Many of Goldhagen's critics protest his assertion that German antisemitism was a rare form of eliminationist antisemitism, that categorically regarded the Jews as an inferior race. The principle critique here is that Goldhagen unwittingly overlooks or actively discounts (depending on the critic) the diversity of attitudes, beliefs, views, temperament, and types of antisemitism pertaining to German and European Jews. Gitta Sereny wrote of Goldhagen's book that it is "a hymn of hate to the Germans." 548 The second main criticism of Hitler's Willing Executioners is that in his explanation of German eliminationist antisemitism at the societal and grassroots levels - Goldhagen ignores the structural complexities of modern German society. In his own defense Goldhagen described his intentions in an interview as having “...tried to return the focus of our attention and understanding of the Holocaust back to the people who were the actual killers of European Jewry. Much of the literature of the Holocaust is devoted to the discussion of structures and institutions and the leadership and pays very little attention to

\footnotetext{
${ }^{546}$ Bartov, The Holocaust, p. 21.

${ }^{547}$ See, for example, Raul Hilberg, The Destruction of the European Hews, revised edition, 3 volumes (New York: Holmes \& Meier, 1985); Raul Hilberg, Perpetrators, Victims, Bystanders: The Jewish Catastrophe 1933-1945 (New York: Harper-Collins, 1992).

${ }^{548}$ Gitta Sereny, “Spin Time for Hitler,” The Observer Review, April 21, 1996.
} 
the people who deported Jews to their death." ${ }^{, 49}$ Perhaps Goldhagen's most prominent critic, and the object of his own work, is the aforementioned Christopher Browning. During the now infamous debate between these two titans of Holocaust Studies. Browning read excerpts from a letter sent to him from a Jewish survivor which, I'm paraphrasing, said he encountered a police company that in his own view could not enact such crimes as Browning and Goldhagen wrote about in their respective books. ${ }^{550} \mathrm{In}$ response, Browning said to the audience in attendance that he believed if this police unit had been instructed to kill Jews, they most likely would have complied with these orders “... and some probably would have behaved with gratuitous and unspeakable cruelty. But I [Browning] doubt that most would have killed willingly and enthusiastically, motivated by the lethal and demonological antisemitism uniformly attributed to such ordinary Germans by Goldhagen."551

The theory developed and put forward in this dissertation argues that some forms of mass political violence - principally state-society coalitions - rely upon a ground swell of societal support for a "punishing," marginalizing, and/or murdering members of a target group en masse. The main distinction my theoretical framework makes is in unpacking different types of perpetrators of mass political violence, from those with little societal involvement in the killing process to episodes with vast communal backing. Is Goldhagen or Browning's perspective of German antisemtism correct? The truth

\footnotetext{
${ }^{549}$ Maurice Wohlgelernter, "Hitler's Willing Executioners: Daniel Jonah Goldhagen Interviewed by Maurice Wohlgelernter" Society Vol. 34, Iss. 2 (1992), p. 32-37.

${ }^{550}$ Goldhagen et al., "The Willing Executioners / Ordinary Men Debate," p. 16.

${ }^{551}$ Goldhagen et al., "The Willing Executioners / Ordinary Men Debate," p. 16.
} 
probably lies somewhere in between these scholarly camps. To some extent, this debate is less important for the purpose of my research. Both sides agree that antisemitism played a substantial role in the evolution of twentieth century's most quintessential example of one group's effort - and near success - at exterminating an entire population. It is also undeniable that a large portion of German and European society participated in pogroms and the systematically of mass murder. Irrespective of the type of antisemtism or other motivating factors like careerism, opportunity, greed, or grievance, my theory of state-society coalitions is supported.

\section{The Cycle of Violence}

As shown in Figure 5.1 the Nazi cycle of violence begins with threat perception. In this case we can see at minimum three clear threats Hitler and the Nazi party acted on. The first threat Hitler was concerned with was the poisoning of the Aryan "master" race by the "inferior" Jewish “disease." Hitler's thinking on this issue was solidified long before he became chancellor of Germany. In his autobiography Mein Kampf Hitler wrote, "Blood mixture and the resultant drop in the racial level is the sole cause of the dying out of old cultures; for men do not perish as a result of lost wars, but by the loss of that force of resistance which is contained only in pure blood. ${ }^{552}$ Hitler's Weltanschauung, or worldview, saw politics and life as struggle between races, though Hitler "denied that the Jews were one [meaning, a race]. ${ }^{" 553}$ Therefore the threat Jews posed to the Aryan race

\footnotetext{
552 Adolf Hitler, Mein Kampf, trans. by Ralph Manheim (New York: Houghton Mifflin Company, [1925] 1971), p. 296, emphasis added.

${ }^{553}$ Timothy Snyder, Black Earth: The Holocaust as History and Warning (London: The Badley Head, 2015), p. 4 .
} 
was not similar to others, but viewed by Hitler as an incurable disease that the master race must be inoculated against. This ideological, psychological, and ecological fear on behalf of Hitler and his accomplices eventually led too fierce (one-sided) intergroup violence for which we now call genocide.

The culmination of Hitler's worldview can be seen in his advocacy of Lebensraum, or living space for Germans. Browning defines Lebensraum as "a long-term process of racial consolidation in the incorporated territories." ${ }^{" 554}$ In other words Lebensraum was the fusion of Hitler's racist politics with German territorial expansion. Hitler delivered a speech to the Reichstag on January 30, 1939 in which he said,

Once again I will be a prophet: should the international Jewry of finance (Finanzjudentum) succeed, both within and beyond Europe, in plunging mankind into yet another world war, then the result will not be a Bolshevization of the earth and the victory of Jewry, but the annihilation (Vernichtung) of the Jewish race in Europe. ${ }^{555}$

Three years later, to the day, Hitler proclaimed again:

We should be in no doubt that this war can only end either with the extermination of the Aryan peoples or with the disappearance of Jewry from Europe. [Hitler went on...] For the first time, the ancient Jewish rule will now be applied: 'An eye for an eye, a tooth for a tooth!' Thereupon messianic ardor took hold of the Nazi leader: World Jewry should know that the more the war spreads, the more anti-Semitism will also spread. ${ }^{556}$

\footnotetext{
554 Christopher R. Browning, The Path to Genocide: Essays on Launching the Final Solution (New York: Cambridge University Press, 1992), p. 23.

555 Max Domarus, edited by Patrick Romane, The Essential Hitler: Speeches and Commentary (Wauconda, IL: Bolchazy-Carducci Publishers, Inc., 2007), p. 399.

${ }^{556}$ Saul Friedländer, The Years of Extermination: Nazi Germany and the Jews, 1939-1945 (New York: Harper Collins Publishers, 2007), p. 332.
} 
I find myself in agreement with Martin Broszat and particularly Christopher Browning, that Hitler's ideology was indicative of his "goal-setting" behavior. Similar to his leader style, Hitler would make his racist ideology a center piece and his subordinates need only look to this worldview for "guidance" in who to attack in aim of securing career advancement or Hitler's favor.

The second and third threats pale in comparison to the aforementioned struggle between races, but are important for understanding Hitler's actions. The second area Hitler was uneasy about was potential challenges to his authority. As illustrated above, Hitler eliminated any political rival inside or out of the Nazi party that could pose a threat to his leadership. This threat was entirely personal to Hitler as compared to the cataclysmic struggle between the Aryan race and the Jews. The final threat was an extension of the former, and was twenty years in the making. It was between Germany and her former rivals who had relegated Germany under the Treaty of Versailles to subordinate state. This was an external threat between Germany and the rest of the world (e.g., western powers, Bolshevism, and European Jewry). Together these three threats embody the bulk of Hitler's motivations for starting World War II and the mass murder of millions.

The formation of a state-society coalition began soon after Hitler took office in 1933. Hitler launched a policy called Gleichschaltung, meaning total coordination and uniformity ${ }^{557}$ Gleichschaltung was a blatant attempt to homogenize society in the "name

557 There were two Gleichschaltung laws passed in 1933 that reorganized the federal and regional governments, giving them more power to allow for conformity with the Reich. See Stuart Elden, "National Socialism and the Politics of Calculation," Social \& Cultural Geography Vol. 7, No. 5 (October 2006), p. 255 . 
of national unity." ${ }^{558}$ Emerging Nazi organizations like the German Labor Front forced out old trade unions and new Nazi organizations for "farmers, women, boys, girls, writers, and artists absorbed associations of people in those categories." 559 Coupled with this fusion between Nazism and society, came all kinds of programs designed to boost Hitler's and the Nazi party's image. This included a massive public relations campaign, public works programs, and other job creation efforts. ${ }^{560}$ Popular culture also played an important role in solidifying this state-society coalition. The introduction of the Hitler salute in 1929 and carried through until his death in 1945 "played an important role in the symbolic struggles of the 1920s and 1930s..."561 This public expression of loyalty to Hitler and the Nazi cause oscillated between symbolic statements of unity to political violence. The Hitler salute was often used as a "first step in street battles of the late Weimar Republic." ${ }^{562}$ The mere act of saluting Hitler demonstrated two things. First a person's clear obedience or at minimum submission to Hitler, and two, his/her recognition of a cause greater than the individual.

Gleichschaltung also permeated popular culture songs. Perhaps the most famous Nazi anthem was "Horst Wessel Lied."563 This song was named after a Nazi

\footnotetext{
${ }^{558}$ Bergen, War \& Genocide, p. 60.

${ }^{559}$ Bergen, War \& Genocide, p. 62.

${ }^{560}$ Bergen, War \& Genocide, p. 63.

${ }^{561}$ Gottfried Korff and Larry Peterson, "From Brotherly Handshake to Militant Clenched Fist: On Political Metaphors for the Worker's Hand," International Labor and Working-Class History No. 42 (1992), p. 81.

${ }^{562}$ Korff and Peterson, "From Brotherly Handshake to Militant Clenched Fist," p. 81.

563 Bergen, War \& Genocide, p. 65.
} 
Stormtrooper who died in a fight between Nazis and Communists in 1930. The lyrics called for "unity against the foe, and praised the comrade-heroes who had died for the cause." ${ }^{564}$ Early on in the process of forming their state-society coalition, the Nazis learned two central lessons. First, it was easier to attack groups who had been marginalized from society Martin Niemöller, a protestant pastor and outspoken critic of Hitler summarized this step-by-step process famously wrote:

First they came for the Socialists, and I did not speak outBecause I was not a Socialist.

Then they came for the Trade Unionists, and I did not speak outBecause I was not a Trade Unionist.

Then they came for the Jews, and I did not speak out Because I was not a Jew.

Then they came for me - and there was no one left to speak for me. ${ }^{565}$

And, second, they learned through (violent) trial and error tactics that "members of the general public were more likely to participate in or at least tolerate attacks on

\footnotetext{
${ }^{564}$ Bergen, War \& Genocide, p. 65.

565 "Martin Niemöller: "First they came for the Socialists..." United States Holocaust Memorial Museum, accessed on April 30, 2018. URL: https://www.ushmm.org/wlc/en/article.php?ModuleId=10007392.
} 
minorities if they stood to gain rather than to lose from such initiatives." ${ }^{, 566}$ In any event, a state-society coalition did not require full social participation, but merely some active collaboration and for the rest of the population to remain indifferent or docile to Nazi actions.

Hitler's interwar escalation of hostilities between the Jews and the rest of German society is just as much, if not, more important than his actions during the war. At least in terms of explaining how society became accustom to the viewpoint that the Jews were to blame for all of Germany's misfortunes. They became a convenient scapegoat for Hitler and his accomplices to rail against. Hitler's National Socialist German Workers Party (otherwise known as the Nazi party) was one of the strongest political parties in interwar Germany. ${ }^{567}$ Despite their relative popularity, the Nazi party was only capable of obtaining a plurality victory (33 percent of the vote) in the 1932 elections. ${ }^{568}$ It was not long after taking power that Hitler moved to end democracy in Germany. Using his charisma, charm, and powers of persuasion, Hitler convinced his cabinet to invoke article 48 of the constitution, an emergency provision that allowed the government to suspend individual freedoms of speech, the press, and assembly. ${ }^{569}$ The Nazi SS, SA, and Gestapo forces arrested or murdered political opponents in the Communist, Socialist, and Liberal

\footnotetext{
566 Bergen, War \& Genocide, p. 60.

567 The Holocaust, p. 1.

568 The Holocaust, p. 1.

569 Bernadette Meyler, "Economic Emergency and the Rule of Law," DePaul Law Review Vol. 56 (2007), p. 545; The Holocaust, p. 1.
} 
political parties and ensured Hitler could wield his dictatorial powers without fear of internal competition. $^{570}$

German prewar and interwar years are pocketed by near constant legal constraints on the Jewish population. In the same year Hitler was elected, new German laws mandated that all Jews quit their "civil service jobs, university and law court positions, and other areas of public life." ${ }^{571}$ Soon after, a boycott was started that targeted Jewish businesses. From 1933 to 1935 Nazi scientists advanced Hitler's racist Social Darwin ideology and advocated for eugenics, or selective breeding to "improve" the human race. ${ }^{572}$ During the same time frame laws were passed to cull the human race of so-called genetically inferior persons, by forced sterilization programs. Tragically, about 500 children of African-German racial backgrounds and between 320,000-350,000 physically and mentally handicapped persons were surgically or through radiation procedures made infertile. ${ }^{573}$ By 1937 there were new laws that segregated Jews from public schools (or banned them outright), movie theaters, vacation resorts, housing areas, and even barred them from walking in certain areas of German cities. ${ }^{574}$ Jews were systematically forced from the formal economy sector. Nazis either seized Jewish businesses and properties or coerced Jewish owners to sell their holdings greatly below market prices. All of which culminated in November 1938 when German SA units and Hitler Youth attacked German

\footnotetext{
${ }^{570}$ The Holocaust, p. 1.

${ }^{571}$ The Holocaust, p. 3.

572 The Holocaust, p. 3-5.

${ }^{573}$ The Holocaust, p. 3-5.

${ }^{574}$ The Holocaust, p. 3-5.
} 
and Austrian Jews, destroyed countless synagogues, Jewish properties, arrested Jewish men, and murdered others in a pogrom that has become known as Kristallnacht, "night or broken glass" or "night of crystal.".575

This mobilization of German paramilitary units and Hitler Youth was a precursor to the eventual perpetrators of Nazi mass political violence. Let me take a moment to describe the perpetrators of the Holocaust and other Nazi genocidal crimes. First, there is a myth that the German military (Wehrmacht) was innocent of crimes perpetrators in what we call the Holocaust. For years the myth propagated by retired soldiers was that the Wehrmacht fought Germany's enemies abroad and the Nazi paramilitary organizations waged war within German borders. This is simply false. Beorn painstakingly chronicles the crimes of the Wehrmacht on the eastern front. Beorn writes: The actions of this company [6 $6^{\text {th }}$ Company, $727^{\text {th }}$ Infantry Regiment] in Slonim (and of other $727^{\text {th }}$ soldiers in surrounding areas) are emblematic of an escalation in Wehrmacht collusion in the Holocaust. German soldiers no longer merely assisted in killings in towns in which they found themselves while advancing. The units in the following cases lived side by side with the Nazi administration and its Jewish victims for extended periods and found themselves involved in far more than just killing. The behavior of German army units in Slonim and Novogrudok demonstrates the depth of this cooperation, in particular how the army negotiated its role in the Nazi genocidal project and the extent to which that role became routinized. ${ }^{576}$

575 "Kristallnacht," United States Holocaust Memorial Museum, accessed on April 30, 2018. URL: https://www.ushmm.org/wlc/en/article.php?ModuleId=10005201.

${ }^{576}$ Beorn, Marching into Darkness, p. 136. 
For a variety of reasons, the Wehrmacht's crimes on the eastern front tended to be neglected by the Nuremburg Military Tribunals in lieu of other high-level SS

perpetrators, the Einsatzgruppen (mobile killing squads), and the atrocities committed by members of the German medical establishment. ${ }^{577}$ What we know beyond the shadow of a doubt, is that German military personnel were not forced to be cold-blooded killers (of civilians). ${ }^{578}$ Anyone who declined to participate in the killing were transformed or given other duties. "To this day no one has ever found a single example of a German who was executed for refusing to take part in the killing of Jews or other civilians... There were enough willing perpetrators. For the most part coercive violence could be reserved for those deemed enemies."

What about societal participation in the Holocaust? Among historians and political scientists, there has been a renewed interest in the question of popular participation in the Holocaust and other Nazi genocidal crimes. ${ }^{580}$ The violence against

\footnotetext{
${ }^{577}$ Beorn, Marching into Darkness, p. 209.

${ }^{578}$ Beorn, Marching into Darkness, p. 158-159.

${ }^{579}$ Bergen, War \& Genocide, p. 158-159.
}

${ }^{580}$ See the following: Vincas Bartusevicius, Joachim Tauber, and Wolfram Wette, Holocaust in Litauen: Krieg, Judenmorde und Kollaboration im Jahre 1941 (Cologne: Böhlau, 2003); Karel C. Berkhoff, Harvest of Despair: Life and Death in Ukraine under Nazi Rule (Cambridge, MA: Belknap, 2004), 59-88; Kate Brown, A Biography of No Place: From Ethnic Borderland to Soviet Heartland (Cambridge, MA: Harvard University Press, 2004), 212-19; Martin Dean, Collaboration in the Holocaust: Crimes of the Local Police in Belorussia and Ukraine (New York: St. Martin's Press, 2000); Christoph Dieckmann, Kooperation und Verbrechen: Fromen der "Kollaboration" im östlichen Europa, 1939-1945 (Göttingen: Wallstein, 2003); David Gaunt, Paul A. Levine, and Laura Palosuo, Collaboration and Resistance during the Holocaust: Belarus, Estonia, Latvia, Lithuania (New York: Peter Lang, 2004); Jan T. Gross, Neighbors: The Destruction of the Jewish Community in Jedwabne, Poland (Princeton, NJ: Princeton University Press, 2001); Wendy Lower, Nazi Empire-Building and the Holocaust in Ukraine (Chapel Hill: University of North Carolina Press, 2004), 86-79; Timothy Snyder, The Reconstruction of Nations: Poland, Ukraine, Belarus, 1569-1999 (New Haven: Yale University Press, 2003), 154-62; Timothy Snyder, Sketches from a Secret War: A Polish Artist's Mission To Liberate Soviet Ukraine (New Haven: Yale University Press, 2005) 180-183; Knut Stang, Kollaboration und Massenmord: Die Litauische Hilfspolizei, das, Rollkommando Hamman und die Ermordung der litauischen Juden (Frankfurt am Mian: Peter Lang, 1996); Amir Weiner, Making Sense of 
targeted populations were carried out in concentration camps, killing centers, or "dedicated sites of annihilation." ${ }^{581}$ German perpetrators, particularly the Einsatzgruppen were supported in their dedicated task of mass murder by Ukrainians, Latvians, Lithuanians and "other east Europeans who were as murderous or worse." ${ }^{\prime 52}$ Even some captured Soviet Red Army soldiers were recruited as "willing helpers" and subsequently saved from the horrors of German prisoner of war camps. ${ }^{583}$ Abram De Swaan argues in his book The Killing Compartments that when regimes engage in "mass annihilation" (his term) they only do so after society has been conditioned and under gone "advanced compartmentalization, a separation of the regime's people from the target group in every sense and at every level. ${ }^{584}$ This compartmentalization process has been written about by other authors in terms of dehumanization tactics or intergroup polarization (c.f., Gregory Stanton's "The 8 Stages of Genocide" and Daniel Chirot and Clark McCauley's Why Not Kill Them All?). Compartmentalization is not sui generis to state-society coalitions. We may see this stratagem employed by any perpetrator category. That said, what is unique about this category is that through much of society "maintains its pacified ways" there is significant proportion within popular society that is allowed to organize and participate in mass political violence.

War: The Second World War and the Fate of the Bolshevik Revolution (Princeton, NJ: Princeton University Press, 2001), p. 239-97.

\footnotetext{
581 Abram De Swaan, The Killing Compartments: The Mentality of Mass Murder (New Haven and London: Yale University Press, 2015), p. 121.

${ }^{582}$ De Swaan, The Killing Compartments, p. 35.

${ }^{583}$ De Swaan, The Killing Compartments, p. 35.

${ }^{584}$ De Swaan, The Killing Compartments, p. 118-119.
} 
The Jedwabne model is prototypical of popular participation during the Holocaust. The main thesis of Jan Gross's book Neighbors: The Destruction of the Jewish Community in Jedwabne, Poland is that the local population killed their Jewish neighbors without coercion. They organized themselves without the assistance of German units and did so willingly and energetically. ${ }^{585}$ During the prelude to murder, the Jews were guarded by almost the entire village and not German forces. The local population also took it upon themselves to dig pits and mobilize into groups for the purpose of murdering their Jewish neighbors. Eyewitness accounts recall cases of extreme brutality toward the Hews in Jedwabne. These were committed anti-Semites who relished the opportunity to punish their neighbors and cleanse the town of their "sins." The Jedwabne model gruesomely highlights the society component of the Holocaust's state-society coalition.

Before turning our attention to decision points in the Holocaust, I must say a few words on perpetrator agency versus situation. There are few - if any - laws in social science. One long held consensus across the fields of political science, history, sociology, political and social psychology, and Genocide Studies is that mass political violence perpetrators are not distinct from society at large. It is situations that allow people to become perpetrators. This is not to say we collectively agree on the causal relationship between situation and the removal of individual prohibitions that allow them to become genocidal killers. I argue that potentially all people are perpetrators, but few perpetrators are capable of being "masterminds" or "leaders" in this odious crime. This distinction

\footnotetext{
${ }^{585}$ Jan T. Gross, Neighbors: The Destruction of the Jewish Community in Jedwabne, Poland (Princeton, NJ: Princeton University Press, 2001), passim.
} 
between the potential of individual persons to be perpetrators and those capable of leading such campaigns is a vital one. This is not to say that social situations excuse individual actions - even in time of war, famine, conflict, crisis, or chaos. A person's moral code also plays a definitive role. "Many of the direct perpetrators are usually not simply forced or pressured by the authorities to obey. Instead, they join leaders and decision makers, or a movement that shapes and guides them to become perpetrators. Decision makers and perpetrators share a cultural-societal tilt," argues Ervin Staub. ${ }^{586}$

\section{$\underline{\text { Decision Points }}$}

We cannot know if Hitler had a master plan that begun in 1933 or earlier, that sought for the total extermination of European Jewry. We can only rely on historical accounts from these years to estimate Hitler's intentions vis-à-vis mass political violence, because he did not survive the war and face prosecution and an investigation for his reasons. With this limitation in mind, I will draw our attention to two decision points that are publically available. Perhaps other decision points exist between Hitler and his collaborators, but we cannot definitively say. The first decision point to overtly engage in mass political violence is inextricably tied to Hitler's decision to invade Poland in September 1, 1939 - thus triggering the Second World War. We know that all major killing episodes of Nazi victim populations took place after the start of the war in 1939. The seven years prior to this event were characterized by increasing legal restrictions of Hews and periodic acts of violence. However, by far the vast amount of death and

\footnotetext{
${ }^{586}$ Quoted in Leonard S. Newman and Ralph Erber, eds. Understanding Genocide: The Social Psychology of the Holocaust (Oxford: Oxford University Press, 2002), p. 21.
} 
devastation that would be endured at the hands of the Nazis was far from over this point in 1939.

It is difficult to know if the decision to murder - en masse - the Jews and other marginalized populations came substantially earlier than 1939 (e.g., 1938, 1937, or even 1930). Because of the limitations in the historical record, I will use September 1939 as the arbitrary date for Hitler's first decision point to commit mass political violence though recognizing it may have been weeks, months, or possibly years in the making. Despite this limitation, there are benefits to using the start of the war as a first marker of violence. The first group to be murdered in mass was not the Jews but so-called people who had "lives unworthy of living," the mentally and physically handicapped. In spring 1939 Hitler authorized Dr. Karl Brandt and Philipp Bouhler to begin a children's “euthanasia" program, where children who fit this description were sent to "special clinics where medical personnel starved them to death or gave them lethal injections." This relatively small program was later expanded after the beginning of the war to include adults with physical and mental disabilities. The program was codenamed "T-4," which was the address of the program's leadership offices in Berlin, Tiergartenstrasse 4. ${ }^{588}$ This class of victims was the first group to undergo the transformation from that of a marginalized and persecuted group to the targets of mass murder.

The second decision point I will elucidate surrounds the Wannsee Conference in January 1942. This is a somewhat fungible marker as well, but one that represents the

\footnotetext{
${ }^{587}$ Bergen, War \& Genocide, p. 128.

${ }^{588}$ Bergen, War \& Genocide, p. 128.
} 
formalization of Nazi plans to exterminate Jews and other victim populations. By 1940 and 1941 the Nazi establishment was under an increasing amount of pressure in finding space for the Jews in German territories and refuges. Adolf Eichmann declared on December 4, 1940 "that Jews were going to be moved to an unnamed location as a preliminary to the final solution of the Jewish problem." 589 Hitler and other senior Nazi leaders like Herman Göring, Martin Bormann, Hans Lammens, Wilhelm Keitel, and Alfred Rosenberg used Stalin's orders of July 3, 1941 to Red Army personnel to "start partisan warfare behind the German lines as one more favorable development...” that gave the Nazis a green light to destroy anything and anyone who stood in their march across the Russian steppe - including innocent Jewish men, women, and children. ${ }^{590} \mathrm{~A}$ year and five days later, Eichmann scheduled a meeting of more than a dozen high ranking Nazi party and German government officials to discuss the "final solution." 591 This now infamous meeting was delayed and rescheduled January 20, 1942 in Wannsee, a suburb of Berlin. ${ }^{592}$ Though gassing operations at Chlemno, one of six killing centers, began one day after the Japanese attack on the U.S. Pacific naval fleet based in Pearl Harbor, the Wannsee Conference formalized the Nazi policy of total extermination. ${ }^{593}$ The SS planned to slaughter some 11 million Jews believed to be in German-controlled

\footnotetext{
${ }^{589}$ Griech-Polelle, Anti-Semitism and the Holocaust, p. 171.

${ }^{590}$ Friedländer, The Years of Extermination, p. 200.

${ }^{591}$ Friedländer, The Years of Extermination, p. 339.

592 "Wannsee Conference and the "Final Solution," United States Holocaust Memorial Museum accessed on May 2, 2018. URL: https://www.ushmm.org/wlc/en/article.php?ModuleId=10005477.

${ }^{593}$ The Holocaust, p. 11.
} 
lands. ${ }^{594}$ To be emphatically clear, it was Nazi policy since 1939 to murder in droves several national, ethnic, racial, religious, political, and sexual minority groups. The Wannsee Conference merely marks the formalization of this process from mass shootings carried out by mobile killing squads in the east to institutionalized concrete, and the mass infrastructure of killing centers. Michael Berenbaum has described this transformation from mass shootings to gas chambers as, a change in tactics. Initially perpetrators sought out victims, they quickly realized this tactic was inefficient and costly, thus they decided to bring the victims to the killers, rather than the other way around. ${ }^{595}$ Mass shootings were both inefficient and "physically and psychologically difficult... [as it required Nazi agents and collaborators] to shoot people all day long at close range." $" 596$

Your chance of survival depended on where you lived. Wherever Jews fled they could expect the Nazi war machine to follow. This constant fear of death followed Jews no matter where they went in German-controlled territories. But, the behavior of local gentile populations "whom Hews lived [with] functioned as a separate factor, that, while not decisive, increased or decreased the chances of Jewish survival." ${ }^{, 597}$ Populations in the east were generally more hostile towards the Jewish people, though there were instances

\footnotetext{
594 "Wannsee Conference and the 'Final Solution,"” United States Holocaust Memorial Museum accessed on May 2, 2018. URL: https://www.ushmm.org/wlc/en/article.php?ModuleId=10005477.

595 Michael Berenbaum, "Religion and the Holocaust in Contemporary Discourse" (presentation, Inaugural Suzanne R. and Dr. Lawrence M. Fishman Scholar-in-Residence, Florida International University, Miami, FL, February 14, 2017.

${ }^{596}$ Bergen, War \& Genocide, p. 164.

597 Diana Dumitru, The State, Antisemitism, and Collaboration in the Holocaust: The Borderlands of Romania and the Soviet Union (New York: United States Holocaust Memorial Museum and Cambridge University Press, 2016), p. 1.
} 
where local groups offered shelter, food, and refuge. One key difference between the Holocaust and the Soviet Union and Cambodian case studies is that "the Germans carried out their systematic murderous activities with the help of local collaborators in many countries and the acquiescence or indifference of millions of bystanders."598 Popular participation took many forms of collaboration including as principal perpetrators, accomplices, and beneficiaries of mass political violence. Hitler's axis partners at the state level was vast. In some allied states the "fascist paramilitary organizations terrorized, robbed, and murdered indigenous Jews, either under German guidance or on their own initiative." 599 The Hlinka Guard in Slovakia, the Iron Guard in Romania, the Ustasa in Croatia, and the Arrow Cross in Hungary were responsible for the deaths of thousands of Jews in their home territories. ${ }^{600}$ Government officials in Hungary, Slovakia, Croatia, Bulgaria, and Vichy France also assisted in the deportation of Jews and the administration of Nazi policy. There was also vast societal support in those territories

\footnotetext{
598 Though not the focus of my dissertation, there was an organized Jewish resistance that was sparked by the scandalous nature of Nazi persecution and mass murder. In Denmark the Danish Resistance with the help of locals saved nearly the entire Jewish community from deportation by organizing an underground smuggling network to neutral Sweden. In Poland, the Jewish Fighting Organization (JFO) took up armed rebellion on April 19, 1943 in response to the mass deportations underway of Jews to the Treblinka concentration camp. Because the Holocaust's aim was to eradicate an entire group's culture, traditions, and customs there was ample spiritual and non-violent resistance too. Individual Jews determined to pressure their "self, or sanity, in a moral universe of rapid disintegration and loss of will..." Under constant threat Jews continued their spiritual resistance "to save the soul, or psyche, from the madness through silence in relation to the oppressor, but not silence in relation to God or to the Jewish community itself."

Cited in order, The Holocaust, p. 13; Roger S. Gottlieb, "The Concept of Resistance: Jewish Resistance During the Holocaust," Social Theory and Practice Vol. 9, No. 1 (Spring 1983), p. 31; James M. Glass, Jewish Resistance During the Holocaust: Moral Uses of Violence and Will (New York: Palgrave Macmillan, 2004), p. 104; "Jewish Resistance," United States Holocaust Memorial Museum, accessed on May 3, 2018. URL: https://www.ushmm.org/wlc/en/article.php?ModuleId=10005213.
}

599 “Collaboration," United States Holocaust Memorial Museum, accessed on April 7, 2018. URL: https://www.ushmm.org/wlc/en/article.php?ModuleId=10005466.

600 "Collaboration," United States Holocaust Memorial Museum, accessed on April 7, 2018. URL: https://www.ushmm.org/wlc/en/article.php?ModuleId=10005466. 
as well. Spontaneous and voluntary "partisan" and "self-defense" groups formed in Lithuania, Latvia, Estonia, Belarus, and Ukraine where they were responsible for killing hundreds of Jews and so-called and card carrying Communists. ${ }^{601}$ These groups were later purged and reorganized by Nazi SS and police units. These local auxiliaries were notorious for their savagery and brutality towards Jewish people and other enemies of the state. Finally, in addition to direct participation in violence, many locals created or spread propaganda against the Jews in hope of legitimizing their actions and mustering additional support from the masses. ${ }^{602}$

Finally, like in other episodes of mass political violence, perpetrators increasingly relied on euphemisms for describing and advocating for mass murder. Whenever Nazis and anti-Semites discuss the "Jewish question" they were referencing the status and illtreatment of the Jews, from persecution in the 1930s, to ghettoization and later extermination. Most communicate in coded language Hitler and his Nazi perpetrators attempt to exterminate all European Jews. This was their answer to the "Jewish question." Jeffrey Herf references Goebbels use of the term "Jewish war," which reflects Hitler's ideological beliefs that the Nazis were engaged in a war between races. ${ }^{603}$ This

601 "Collaboration," United States Holocaust Memorial Museum, accessed on April 7, 2018. URL: https://www.ushmm.org/wlc/en/article.php?ModuleId=10005466.

602 Hitler would constantly "link the grand historical narrative of a war between Aryan Europe and international Jewry with the biographies of countless individuals." Hitler and his many accomplices would ascribe secret powers to the Jewish people including having the ability to bring "England into World War I and "stab Germany" in the back." Joseph Goebbels, minister of propaganda, was deeply involved in the antiSemitic propaganda campaign throughout the interwar and war periods. Goebbels frequently asserted that a "world cabal" was behind Germany's enemies. He constantly pushed all German newspapers and periodicals to stress the "Jewish danger and the need to remove it." See Jeffrey Herf, The Jewish Enemy: Nazi Propaganda During World War II and the Holocaust (Cambridge, MA and London: The Belknap Press of Harvard University Press, 2006), p. 144, 152, 215, and 217, respectively.

${ }^{603}$ See Jeffrey Herf, “The 'Jewish War': Goebbels and the Antisemitic Campaigns of the Nazi Propaganda Ministry,” Holocaust and Genocide Studies Vol. 19, No. 1 (Spring 2015), p. 51-80. 
dehumanization of Jewish persons continued with many in German society attributing vile terms to Jews, such as calling them "vermin," a "virus," or "parasites."604 There was also coded language used by SS and military personnel in official reports to make their barbaric actions towards seem legal or mundane. Whenever an official wrote they performed an "evacuation from the east," this meant they were exterminating Jews after January 1942 , or deporting them to killing centers. ${ }^{605}$ If the perpetrators wrote "shot while trying to escape," it was a euphemism for cold blooded murder. ${ }^{606}$ One order read, "All male Jews between 17-45 years of age convicted of looting are to be executed immediately," Richard Rhodes notes, "Since the battalions conducted neither investigations nor trials, the word "convicted" was a fig leaf and a euphemism for killing." tasks" or "executive measures." 608 Such euphemisms did not stop with the Jews. Nazis also used the terms "euthanasia" and "mercy deaths" to disguise their blatant killing of those considered to be "idiots," "crazies," and "cripples." 609 The use of euphemisms are

\footnotetext{
604 Emil L. Fackenheim, "The Holocaust and Philosophy," The Journal of Philosophy Vol. 82, No. 10 (October 1985), p. 507-508.

${ }^{605}$ Friedländer, The Years of Extermination, p. 340.

${ }^{606}$ Richard Rhodes, Master of Death: The SS-Einsatzgruppen and the Invention of the Holocaust (New York: Vintage Books, 2003), p. 7.

${ }^{607}$ Rhodes, Master of Death, p. 7.

${ }^{608}$ Rhodes, Master of Death, p. 14.

${ }^{609}$ Henry Friedlander, The Origins of Nazi Genocide: From Euthanasian to the Final Solution (Chapel Hill and London: The University of North Carolina Press, 1995), p. xxi-xxii.
} 
both attempts to justify perpetrator behavior and obfuscate their actions from the public (and historical) record.

\section{The Victims}

The Holocaust and other Nazi genocidal crimes has had profound effects in the way we view one-sided violence against a civilian or noncombatant population. European Jews were the primary victims of Hitler's Germany and its collaborators throughout Europe, North Africa, and Asia Minor. Of the 11 million Jews targeted for extermination, Nazi perpetrators butchered more than half the Jews (approximately six million men, women, and children) were not the only group in Nazi-controlled lands to face the iron fist of Hitler's henchmen and women. The Roma (or Gypsies) and Sinti peoples were regularly targeted, the Poles endured many years of German occupation and terror, other religious minorities like Jehovah's Witnesses were placed on Hitler's enemies list, sexual minorities (LGBT+ persons) were systematically persecuted and killed, political dissidents and Soviet Red Army prisoners also endured brutal conditions in the camps, and of course those deemed a drag on society and possessing "life unworthy of living" were "euthanized" or more accurately put to death within days of the German advance into Poland. The Nazis began their campaign of cultural genocide, en effort to destroy Polish culture and enslave them as they were deemed "sub-human." ${ }^{\prime 10}$ The first wave of atrocities targeted "university professors, artists, writers, politicians, and many catholic priest," in essence the core socio-political groups in Polish society. ${ }^{611}$ This was essential

\footnotetext{
${ }^{610}$ The Holocaust, p. 7.

${ }^{611}$ The Holocaust, p. 7.
} 
to the German plan, as Poland was eventually to be a new living space, Lebensraum, for the superior German people. As such, Polish territory would become a "laboratory for experiments in spatial expansion and racial ideology." $" 12$

The T4 program, so-called euthanasia program, began in secret with Hitler ordering medical staff to kill those who were "incurable." ${ }^{613}$ Here special commissions (ones that people could argue were real death panels) reviewed questionnaires completed by all state run hospitals and made the final decision to kill or spare patients. ${ }^{614}$ Once a patient was placed on the kill list, they were transferred to one of six institutions in Germany and Austria that were designated as killing centers for the T4 program. ${ }^{615}$ There were specially constructed gas chambers established at these six killing centers to handle the influx in "patients." After some public outcry and protests to the program in 1941, the Nazi continued the program in secret and killed babies, small children, and others through lethal injection or forced starvation. ${ }^{616}$ There is still a debate over the precise motivations for implementing T4. Michael Burleigh argues that T4 was used as a policy

\footnotetext{
${ }^{612}$ Bergen, War \& Genocide, p. 101.

${ }^{613}$ The Holocaust, p. 7.

${ }^{614}$ The Holocaust, p. 7.

615 The six killing centers were established at Brandenburg, Grafeneck, Gartheim, Sonnenstein, Bernbars, and Hadamar. See Rael D. Strous, "Images in Psychiatry: Nazi Euthanasia of the Mentally Ill at Hadamar," American Journal of Psychiatry Vol. 163, No. 1 (January 2006), p. 27; Maike Rotzoll, Paul Richter, Petra Fuchs, Annette Hinz-wessels, Sascha Topp, and Gerrit Hohendorf, "The First National Socialist Extermination Crime: The T4 Program and Its Victims," International Journal of Mental Health Vol. 35, No. 3 (Fall 2006), p. 22.

${ }^{616}$ The Holocaust, p. 7.
} 
to "clear the decks" in advance of war. ${ }^{617}$ This is a somewhat programmatic view of why the Nazis targeted the mentally and physically disabled. Henry Friedlander asserts that Nazi motivations were much deeper. He argues that this extermination policy was a logical extension of Hitler's racial ideology. In this vein the Nazi genocide against the mentally and physically impaired was part of Hitler's race war to cull the biologically inferior from the herd so that the Aryan race remained genetically superior to all others. ${ }^{618}$ Perhaps both Burleigh and Friedlander are correct about Nazi motivations. Under T4 about 200,000 patients were killed. ${ }^{619}$ To prove $\mathrm{T} 4$ was a precursor to other Nazi killing centers, Dr. Imfried Eberl, a psychiatrist with direct involvement in T4 at the Brandenburg facility, became the first commandant of the Treblinka death camp, where he modeled the killing center after his own experiences in $\mathrm{T} 4 .{ }^{620}$

During the war, the Nazis and their collaborators constructed ghettos, transit camps, labor camps, and concentration and death camps to house and ultimately slaughter Jews, Roma and other victim populations. ${ }^{621}$ Like Warsaw, Lublin, and Krakow, Jews were essentially imprisoned in ghettos. The harsh conditions and perpetual influx of new arrivals led to starvation diets, overcrowding, and rampant outbreaks of contagious

\footnotetext{
${ }^{617}$ See Michael Burleigh, "Psychiatry, German society and the Nazi "euthanasia" programme," in Omer Bartov eds., The Holocaust: Origins, Implementation, Aftermath (London and New York: Routledge, 2000), p. $43-62$.

${ }^{618}$ See Henry Friedlander, "Step by step: the expansion of murder, 1939-1941," in Omer Bartov eds., The Holocaust: Origins, Implementation, Aftermath (London and New York: Routledge, 2000), p. 63-76.

${ }^{619}$ Martin Winestone, The Holocaust Sites of Europe: An Historical Guide (London and New York: I.B. Tauris, 2015), p. 8-9.

${ }^{620}$ Strous, "Images of Psychiatry," p. 27.

${ }^{621}$ The Holocaust, p. 8.
} 
diseases that claimed thousands of lives. As the war progressed the Nazis began to systematically deport Jews from the approximate 1,000 ghettos to the newly established death camps.

The six sites for Nazi death camps were chosen specifically for their proximity to major railroads lines. ${ }^{622}$ These killing centers were located at Belzec, Sobibor, Treblinka, Chelmno, Majdanek, and Auschwitz-Birkenau. The first camp to begin mass executions was Chelmno. The camp's perpetrators pumped gas into mobile vans, a crude and barbaric step toward the ultimate path of constructing gas chambers. Between December 1941 and March 1943, and between June to July 1944, about 320,000 people were massacred. ${ }^{623}$ At Belzec, between May 1942 and August 1943, more than 600,000 were killed in mobile gas vans and later gas chambers. ${ }^{624}$ In Sobibor, up to 200,000 people were dispatched via gas. Treblinka was physically the largest of the killing centers. It opened in July 1942 and closed 17 months later; at minimum 750,000 persons were killed in this facility. ${ }^{625}$ In Majdanek, many of the 275,000 people who were killed died from either gassings or malnutrition, brutality at the hands of guards, or disease.${ }^{626}$ Finally, Auschwitz-Birkenau was the camp where the most European Jews and Roma were killed in. More than 1.25 million people were killed here, with nine out of 10 of them Jews. ${ }^{627}$

\footnotetext{
${ }^{622}$ The Holocaust, p. 11.

${ }^{623}$ The Holocaust, p. 11.

${ }^{624}$ The Holocaust, p. 11.

${ }^{625}$ The Holocaust, p. 11.

${ }^{626}$ The Holocaust, p. 11.

${ }^{627}$ The Holocaust, p. 11.
} 
Most victims of the death camps were murdered soon after their arrival. Those who survived this deadly initiation to camp life were forced to endure the most unthinkable living conditions. Primo Levi, an Italian-Jewish chemist, writer, and Auschwitz-Birkenau survivor wrote, "Dying was easy," however, "To live was much more difficult and dangerous." ${ }^{628}$ To highlight for the reader how fast the Nazi regime and its accomplices formalized the extermination process, Bergen writes that "at the beginning of $1942 \ldots 75$ percent of the Jews who would be murdered in the Holocaust were still alive. By the beginning of 1943, 75 percent of the approximately 6 million who would be killed were already dead." 629 As the war gradually turned again Germany in the East, West, and Southern (Italian) fronts, the SS began evacuating the death and concentration camps closest to invading armies in hope of maintaining their secrecy from outside eyes. Many prisoners who had survived in the concentration camps to this point died during the long forced marches. ${ }^{630}$

There is much to say about gender and mass political violence. Men and women faced both similar and different circumstances during the Holocaust. The title of Myrna Goldenberg and Amy Shapiro's book sums up the disparity Different Horrors, Same Hell. ${ }^{631}$ During the first two years of the war Jewish men were more likely to die in Polish forced labor camps, but from 1941 to 1942 women were more likely to be

\footnotetext{
${ }^{628}$ The first quote is by Primo Levi and the second by Carole Angier in The Double Bond: Primo Levi a Biography (New York: Farrar, Straus and Giroux, 2002), p. 306.

${ }^{629}$ Bergen, War \& Genocide, p. 182-183.

${ }^{630}$ The Holocaust, p. 13.

${ }^{631}$ See Myrna Goldenberg and Amy H. Shapiro, Different Horrors, Same Hell: Gender and the Holocaust (Seattle, WA: University of Washington Press, 2013), passim.
} 
deported to killing centers. ${ }^{632}$ Upon arrival this disparity continued. Men were more likely to be consigned to physical labor tasks while women - especially those pregnant or accompanied by small children - almost always were sent directly to the gas chambers. ${ }^{633}$ Joan Ringelheim interviewed 20 women survivors for her 1985 article on "Women and the Holocaust." Ringelheim says,

They spoke of their sexual vulnerability: sexual humiliation, rape, sexual exchange, pregnancy, abortion, and vulnerability through their children - concerns that men either described in different ways or, more often, did not describe at all. Almost every woman, referred to the humiliating feelings and experiences surrounding her entrance to the camp (for my [Ringelheim] interviewees, this was Auschwitz): being shaved all over - for some being shaved in a sexual stance, straddling two stools; being observed by men, both fellow prisoners and SS guards... some women remember the ways in which sex was used as a commodity in the ghettos; sexual exchanges for food or other goods involved Jewish men at least as often as, perhaps more often than, they did Nazi authorities. ${ }^{634}$

The negative psycho-social effects of Nazi perpetrators were particularly pronounced in childhood survivor stories. Those who had experienced sexual assault,

\footnotetext{
${ }^{632}$ Bergen, War \& Genocide, p. 191.

${ }^{633}$ Bergen, War \& Genocide, p. 191.

${ }^{634}$ Joan Ringelheim "Women and the Holocaust: A Reconstruction of Reserves," Signs Vol. 10, No. 4 (Summer 1985), p. 743-744.
} 
physical abuse, kidnapping, terrorism, or starvation reported a (sometimes lifelong sense of terror and vulnerability. ${ }^{635}$

All told, Nazi perpetrators and their collaborators killed about 250,000 Roma, including many children. ${ }^{636}$ Thousands more underwent forced sterilization to prevent them from "infecting" the "master race." Himmler, the SS leader, viewed the Roma (Gypsies) as did many Nazi leaders as racially inferior. Himmler's perverse fascination with the Roma people went so far as to propose the construction of a human zoo, where some Roma people could live and be preserved for future research by German scientists. ${ }^{637}$ These so-called "experts" estimated that only three to four percent of the Roma people would fall into this category; but Himmler subsequently abandoned the idea all together. ${ }^{638}$

Finally, I will say a few words about the homosexual experience in World War II. Something Günter Grau calls the "hidden holocaust." By the time the war started, there was about 1.5 to 2 million homosexuals living in Germany. ${ }^{639}$ Hitler had persecuted homosexuals throughout his tenure in office. Between 1933 and 1945, the Nazi regime

\footnotetext{
${ }^{635}$ Rachel Leu-wiesel and Marianne Amir, "Holocaust Child Survivors and Child Sexual Abuse," Journal of Child Sexual Abuse Vol. 14, No. 2 (2005), p. 71.

${ }^{636}$ Bergen, War \& Genocide, p. 200.

${ }^{637}$ Bergen, War \& Genocide, p. 201.

${ }^{638}$ Bergen, War \& Genocide, p. 201.

${ }^{639}$ Günter Grau, "Final Solution of the Homosexual Question? The Antihomosexual Policies of the Nazis and the Social Consequences for Homosexual Men," in Michael Berenbaum and Abraham J. Peck eds., The Holocaust and History: The Known, the Unknown, the Disputed, and the Reexamined (Washington, D.C., Bloomington and Indianapolis: United States Holocaust Memorial Museum and Indiana University Press, 1998), p. 338.
} 
had arrested and convicted 50,000 men with charges related to homosexuality. ${ }^{640}$ Gay men were a particular threat to Nazi racial ideology, because from their perspective, gay men refused to take part in procreating children for the fatherland. ${ }^{641}$ By wars end, about $5,000-7,000$ of these "deviants" perished, with about half of them in concentration camps. There is little research on the lesbian experience during the Holocaust. According to Günter Grau:

...It is not clear how many women had to undergo the horror of a concentration camp because of their homosexuality; most lesbians were spared that fate if they were prepared to conform. What is certain is that there was no systematic prosecution of lesbian women comparable to that of male homosexuals. ${ }^{642}$

Even within the concentration camp system homosexuals were at the bottom of

the social hierarchy. Rüdiger Lautman notes:

The prisoners with the pink triangle were burdened with the general stigmatization of homosexuality; this reduced from the outset their influence on the internal communication and power structures of the camps...the individualistic, as opposed to collective, strategy of seeing to their own interests, which was already imposed on the in the outside world, could work only further against them in the camps. ${ }^{643}$

One problem of Holocaust and Genocide Studies is how to deal with the enormous number of perpetrators, victims, locations, documents, and information. The main goal in this case study is to apply the core theoretical framework of my research to

${ }^{640}$ Bergen, War \& Genocide, p. 202.

${ }^{641}$ Bergen, War \& Genocide, p. 202.

${ }^{642}$ Günter Grau eds., Hidden Holocaust? Gay and Lesbian Persecution in Germany 1933-45 (Chicago and London: Fitzroy Dearborn, 1995), p. 15.

${ }^{643}$ Rüdiger Lautman, "The Pink Triangle: Homosexuals as "Enemies of the State" in Michael Berenbaum and Abraham J. Peck eds., The Holocaust and History: The Known, the Unknown, the Disputed, and the Reexamined (Washington, D.C., Bloomington and Indianapolis: United States Holocaust Memorial Museum and Indiana University Press, 1998). p. 352-353. 
Nazi Germany's persecution and mass murder of millions. Inevitably, this application of my theory to the Holocaust and other Nazi genocidal atrocities limits the overall analysis and depth of my study. Much has been written on the Holocaust and there remains much to be said. This case study moves our analytical understanding of the conditions before, during, and after the Holocaust, but more is needed.

\section{The Rwandan Genocide}

Rwanda is a beautiful mountainous country, often called the jewel of Africa. According to her colonial masters, Rwanda was "inhabited by slender, giant Tutsi, stocky Hutu, and dwarf-like Twa." ${ }^{644}$ The Tutsi were primary cattle herders and emigrated to Rwanda in the fifteenth or sixteenth centuries. ${ }^{645}$ The Hutu population was traditionally agriculturalists and emigrated from the central African region. There is general consensus that the Hutus made up roughly 85 percent of the national population, the Tutsi were about 14 percent, and the Twa approximately one percent prior to the 1994 genocide. These figures should be taken with a grain of salt because scholars continue to debate whether the Hutu government consistently underreported Tutsis in the 1991 national census. ${ }^{646}$ Therefore, the Tutsi population on April 6, 1994 cold have been anywhere between 8.4 and 14 percent, based on scholarly estimates extrapolated from the most

\footnotetext{
${ }^{644}$ W.M. Roger Louis, Ruanda-Urundu: 1884-1919 (Oxford: Clarendon Press, 1963), p. 3.

${ }^{645}$ Peter Uvin, "Prejudice, crisis and genocide in Rwanda African Studies Review 40:2 (1997), p. 92.

${ }^{646}$ Alison Desforges, Leave None to Tell the Story: Genocide in Rwanda (Human Rights Watch, March 1999), p. 17.
} 
recent pre-genocide census. ${ }^{647}$ Rwanda was a German colony in 1894 used primarily for economic exploitation. ${ }^{648}$ After Germany's defeat in World War I, Belgium seized Rwanda through a League of Nations mandate in 1918. According to W.M. Roger Louis, Belgium's acquisition of Ruanda-Urundi [Rwanda and Burundi] is surely one of the greatest ironies in the history of Africa. For her statesmen did not want it. They intended to use Ruanda-Urundi as a pawn to gain the southern bank and mouth of the Congo-river, which they considered as indispensable for the security of their colony... The Belgians thought it regrettable that they would not be allowed simply to absorb Ruanda-Urundi into the Congo. ${ }^{649}$ This lackluster management style and active resentment of the indigenous population would prove neither beneficial for Rwanda or its population.

\section{Existing Polity Structure}

In discussing African politics, it has become natural to use the phrase "state power," in describing a regime's ability to govern its territory. This term is insufficient and broad. It is for this reason that I have separated this term into two parts: regime power and state capacity. Remembering from chapter three, regime power is a function of public and private sector support for senior political and military elites; while state capacity is the degree state agents possess over all persons, activities, and resources

\footnotetext{
${ }^{647}$ Desforges, Leave None to Tell the Story, p. 17.

${ }^{648}$ Louis, Ruanda-Urundu, p. 124.

${ }^{649}$ Louis, Ruanda-Urundu, p. 255-256.
} 
within their territory. A traditional explanation of the genocide by scholars partly blame state weakness or state collapse (c.f., Storey 2001; Collins 1998) ${ }^{650}$ In fact this is a misnomer, Rwanda possessed one of Africa's strongest regimes. According to Scott Straus, the Rwanda state had "unusual depth and resonance at the local level, which meant, that by controlling the state, the hardliners [and advocates of genocide] had the capacity to enforce their decisions countrywide." ${ }^{651}$

On July 5, 1973 Major General Juvénal Habyarimana directed the army to carry out a bloodless coup against fellow Hutu president Grégoire Kayibanda ${ }^{652}$ Habyarimana ruled Rwanda until his death on April 6, 1994. As president, Habyarimana had the ability to garner vast amounts of regime power, and he did. As head of the army, Habyarimana held the allegiance of about 7,000 troops, of which about 1,200 were gendarmerie, or national police. He was also supported by elite Presidential Guard units, which would be crucial in the early hours of the genocide. These elite troops totaled between 1,000 and $1,300 \cdot{ }^{653}$ Habyarimana enjoyed support from outside the military too. He could regularly count on the heads of Rwanda's parastatal corporations (e.g., of gas, water, electricity, or bus transport) to rally to his side when needed ${ }^{654} \mathrm{He}$ could also count on the heads of

\footnotetext{
${ }^{650}$ See Andy Storey, "Structural Adjustment, State Power \& Genocide: The World Bank \& Rwanda," Review of African Political Economy Vol. 28, No. 89 (2001), p. 365-385; Barrie Collins, Obedience in Rwanda: A Critical Question (Sheffield: Hallam University School of Cultural Studies, 1998).

${ }^{651}$ Scott Straus, The Order of Genocide: Race, Power, and War in Rwanda (Ithaca and London: Cornell University Press, 2006), p. 8.

${ }^{652}$ Mahmood Mamdani, When Victims Become Killers: Colonialism, Nativism, and the Genocide in Rwanda (Princeton, NJ: Princeton University Press, 2001), p. 138.

${ }^{653}$ Desforges, Leave None to Tell the Story, p. 39.

${ }^{654}$ Desforges, Leave None to Tell the Story, p. 39.
} 
hospitals, university professors, and the Catholic Church for support. Though the Catholic Church initially endorsed the Tutsi elite, they saw the coming 1959 Hutu revolution and preemptively switched sides. Habyarimana benefited greatly from the church's support, especially since 62 percent of Rwandans identified as Catholic. ${ }^{655} \mathrm{He}$ was less popular among protestant churches. There was "no unified position towards Habyarimana," but the Anglican and Baptist churches generally supported his reign. ${ }^{656}$ As you can see, Habyarimana possessed substantial military, political, economic, and moral power and authority during his tenure.

With respect to regime power, Rwanda was a unique case in itself. Both Habyarimana and his wife wielded significant political power. Habyarimana's wife, Agathe, directed a small organization initially called "le clan de Madame," and later the Akazu, or "little house." ${ }^{657}$ The Akazu was an elite, special circle of friends and relatives of Madame Habyarimana that supported her husband and in some cases pushed him towards more radical policies. "When necessary, this group drew on military officials, like Col. Théoneste Bagosora, Major Lenard Nkundiye, and Captain Pascal Simbikangwa, to ensure their continued hold on power." ${ }^{658}$ Moreover the Akazu exacerbated the regional north-south conflict in Rwanda's ruling elite. Most of its members were from Habyarimana's home town and region (the north). This special circle

\footnotetext{
${ }^{655}$ Desforges, Leave None to Tell the Story, p. 39.

${ }^{656}$ Desforges, Leave None to Tell the Story, p. 39.

${ }^{657}$ Gérard Prunier, The Rwanda Crisis: History of a Genocide (New York: Columbia University Press, 1995), p. 85 .

${ }^{658}$ Desforges, Leave None to Tell the Story, p. 40.
} 
of leaders exercised control over state-sponsored rural investments to maintain patronage networks and personal loyalties. ${ }^{659}$

Gérard Prunier found three reasons the Akazu played an important role in Rwandan politics. First, Habyarimana relied on these supporters as "his ears and eyes" who were outside the official chain of command, to provide him with information and "unequivocal devotion." 660 The second reason is that, at least initially, Habyarimana did not have faithful followers inside government, because he initiated a coup against the first president, who was a southerner. There were even rumors propagated that Habyarimana was not Rwandan, but born in Uganda or Zaire. Therefore, these Mafiosos provide him with additional muscle. Finally, Madame Agathe was a descendant from an elite family who ruled northern principalities till the late nineteenth and early twentieth centuries. ${ }^{661}$ She became so powerful that her nickname was Kanjogera, a brutal mother of King Musinga, and supposedly "the real power behind the throne."662

Furthermore, the Rwandan state possessed "unusual depth and resonance at the local level." ${ }^{, 663}$ When the genocide unfolded, it was greatly enabled by the strong administrative state already established. One example of the state's strength was the policy of umuganda, mandatory unpaid communal labor for all able bodied adults. ${ }^{664}$

\footnotetext{
${ }^{659}$ Linda R. Melvern, A People Betrayed: The role of the West in Rwanda's genocide (London and New York: Zed Books, 2000), p. 42.

${ }^{660}$ Prunier, The Rwanda Crisis, p. 85.

${ }^{661}$ Prunier, The Rwanda Crisis, p. 86.

${ }^{662}$ Prunier, The Rwanda Crisis, p. 86.

${ }^{663}$ Straus, The Order of Genocide, p. 8.

${ }^{664}$ Desforges, Leave None to Tell the Story, p. 38-39.
} 
Habyarimana's political party, the MRND, required people to participate in umuganda and perform manual labor tasks, such as, repairing or constructing roads, clearing brush, "digging anti-erosion ditches" that benefited the community. ${ }^{665}$ The benefits were two fold. First, through monthly mandatory physical labor projects, economic and community development advanced. Second, the government demonstrated its ability to mobilize mass populations for its own aims. During the genocide, the task was not road repair but extermination of the Tutsi.

The strength of Rwandan institutions and state capacity date back to the reforms of the 1920s. These reforms had three effects on the development of Rwanda's state capacity. First, power was transformed from the Mwami, or monarch to chiefdoms at the local levels. Second, accompanying this power shift was a reorganization of local authorities that systematically stripped away local, vertical accountability measures and all internal checks and balances to chief's powers by the governmental bureaucracy. The final effect of these reforms resulted in the radicalization of local government; a precursor to intergroup hostilities of the 1950s and beyond. ${ }^{666}$ All of which led to the eventual strengthening of the local administrative state. The same state apparatuses that would prove essential in the spread of genocide from Kigali outward. Another aspect of colonial reforms that would provide decisive in how perpetrators carried out genocidal acts was the introduction of national identification cards by Belgian colonial overlords. It appears that Belgian colonial officials issued identity cards in Rwanda, in the 1930s, for

\footnotetext{
${ }^{665}$ Desforges, Leave None to Tell the Story, p. 38-39.

${ }^{666}$ Mamdani, When Victims Become Killers, p. 90.
} 
the primary purpose of implementing the host nation's policy during the interwar years. ${ }^{667}$ According to Timothy Longman, a top authority on state-society relations in Africa, “...it does not appear that the cards were issued for the express purpose of registering ethnic identities. Rather, registering ethnicity was merely one component of a broader program to increase the regulation of Belgian subjects." ${ }^{\prime 68}$ This seemingly banal regulatory policy transformed identity cards into "death warrants for many Tutsi in 1994. ${ }^{9669}$ Both the reforms of the 1930s and the introduction of identity cards supported the expansion of the Rwandan state and enabled a vast bureaucracy that was later used to propagate unspeakable crimes in 1994.

Now let me turn to the most compelling aspect of state-society coalitions popular participation in mass political violence. René Lemarchand writes, "Tempting though it is to portray all 'grass-roots killers' as zombies mechanically responding to orders from above, the realities on the ground tell a more complex story." ${ }^{" 670}$ Many bystanders and international observers remarked in response to the genocide, that it seemed like "a people gone mad." ${ }^{\prime 671}$ However, within this "madness" there was

${ }^{667}$ Timothy Longman, "Identity Cards, Ethnic Self-Perception, and Genocide in Rwanda," in Jane Caplan and John Torpey, eds., Documenting Individual Identity: The Development of State Practices in the Modern World (Princeton and Oxford: Princeton University Press, 2001), p. 352-353.

${ }^{668}$ Longman, "Identity Cards," p. 352-353.

${ }^{669}$ Desforges, Leave None to Tell the Story, p. 19.

${ }^{670}$ Lemarchand borrows the term "grass-roots killers" from famed Holocaust historian Christopher Browning. Browning used this term to differentiate low-level perpetrators who were separate from the state's military and paramilitary forces. See Christopher Browning, "Ordinary Germans or Ordinary Men," Address and Response at the Inauguration of the Dorot Chair of Modern Jewish and Holocaust Studies (Emory University, Atlanta, 1994), p. 9. For Lemarchand's quote see René Lemarchand, "Disconnecting the threads: Rwanda and the Holocaust reconsidered," Journal of Genocide Research Vol. 4, No. 4 (2002), p. 512.

${ }^{671}$ Desforges, Leave None to Tell the Story, p. 6. 
organization, collective action, planning, and deliberate acts designed to murder all Tutsis and moderate Hutus who stood in the way of national "progress." There were "hundreds of thousands" of people who actively chose to participate in the genocide or were coerced under fear, punishment, threat of punishment, or peer-pressure to aid in this national effort. For the ideological zealots, murder was easy. With each swing of the machete they were cleansing Rwanda of this so-called "foreign" presence. But for those bullied into participation they "had to decide repeatedly whether or not to participate, each time weighing the kind of action planned, the identity of the proposed victim, the rewards of participating, and the likely costs of not participating." ${ }^{972}$ Because Hutu hardliners took control of the state immediately after Habyarimana's assassination, any person who waivered in partaking in the violence could reassure themselves that participation was legally acceptable because genocide was sanctioned by the state. This formal nod to perpetrators gave each Rwandan a license to kill. Finally, if the legal endorsement of violence was not sufficient in motivating people to murder, there was also moral backing from churches. Whatever the individual reason for participation, churches played a key role in making popular participation in the genocide morally acceptable. ${ }^{673}$ Moreover, church leaders, personnel and "lay leaders" were implicated in the genocide by their cooperation with perpetrators and active participation. ${ }^{674}$

\footnotetext{
${ }^{672}$ Desforges, Leave None to Tell the Story, p. 7.

673 Timothy Longman, Christianity and Genocide in Rwanda (Cambridge: Cambridge University Press, 2010), p. 307.

${ }^{674}$ Timothy Longman, "Church Politics and the Genocide in Rwanda," Journal of Religion in Africa Vol. 31, Iss. 2 (2001), p. 163.
} 
There are several explanations offered in the literature for why ordinary Rwandans participated in the genocide. Omar McDoom calls the traditional view that ordinary Rwandans blindly obeyed state institutions during the genocide. McDoom argues that political and communal dynamics at the sub-national and local levels were essential to grassroots participation in the killing. ${ }^{675}$ In his work "Rwanda's Ordinary Killers" McDoom highlights variation in popular participation between north and south provinces. The MRND carried out many of the massacres led by its militia, the Interahamwe, in direct response to the assassination of their leader, Habyarimana. This means northern perpetrators were ideological zealots committed to the cause and required little to no encouragement to kill. However, for the south, they were far removed from the war with the RPF and genocidaires here were "social intermediaries" who coerced grassroots participation while encouraging others to take advantage of the opportunity, their racist views, or ideological propaganda to kill. ${ }^{676}$

The second explanation of ordinary Rwandan participation was advanced by Lee Ann Fujii who found support for McDoom's analysis of southern motivations for murder also present in some northern and central principalities. ${ }^{677}$ Building on McDoom's analysis that questions the overarching narrative from the state and individual obedience, she argues that four motives were major triggers of participation: social-group dynamics,

675 Omar McDoom, "Rwanda's Ordinary Killers: Interpreting Popular Participation in the Rwandan Genocide," Crisis States Research Centre Working Papers Series, 1, 77 (London: Crisis States Research Centre, London School of Economics and Political Science, 2005).

${ }^{676}$ McDoom, “Rwanda’s Ordinary Killers,” p. 11.

${ }^{677}$ Lee Ann Fujii, Killing Neighbors: Webs of Violence in Rwanda (Ithaca, NY: Cornell University Press, 2009). 
volunteerism, coercion, and individual grievances coupled with family rivalries as motivating factors. Straus found support for these explanations and argued that ordinary Hutus were aided in their killing of Tutsis because they viewed all civilian Tutsis as “guilty by association.” Straus calls this "collective ethnic categorization," where perpetrators viewed Tutsi neighbors who held no affiliation with the RPF as rebel spies or co-conspirators. This collective association rationalized killing of these civilians in the eyes of many Hutu perpetrators. ${ }^{678}$ Finally, Jean-Paul Kimonyo compares mass participation by ordinary Rwandans to the concentration camp system used in the Holocaust. In contrast to the Holocaust, Rwandan perpetrators used "a large part of the general Hutu population... [As] responsible for blocking Tutsis escape." ${ }^{679}$ In essence, Kimonyo argues through widespread mass participation, perpetrators transformed the entire country into one big concentration camp.

In pre-genocide Rwanda the state was linked to society, in part, through political parties. Facing domestic and international pressure, Habyarimana began to open the political space in July 1990. Within eleven months Habyarimana had allowed a constitutional amendment that opened the political system to multiple parties. However, seeing the writing on the wall, some political parties began forming before this constitutional amendment. In all 15 were created. This one act by Habyarimana led to "...a brash and exuberant rush to publicize their cause and to recruit new members, party activists sporting caps and shirts with the party colors held demonstrations and

\footnotetext{
${ }^{678}$ Straus, The Order of Genocide, p. 9.

${ }^{679}$ Jean-Paul Kimonyo, Rwanda's Popular Genocide: A Perfect Storm, trans. by Wandia Njoya (Boulder, $\mathrm{CO}$ and London: Lynne Reiner Publishers, 2016), p. 353.
} 
meetings... Local leaders flew the party flag on poles outside their homes or businesses, proud to be identified as the key persons for mobilizing adherents in that area." ${ }^{680}$ These political parties organized youth wings which inevitably engaged in violence against their opponents.

The MRND's youth group was the infamous Interahamwe, the Kinyarwanda word for "we fight together." 681 The radical MDR formed its youth wing, the Inkuba, or "thunder," and along with the Abakombozi, or "the liberators" of the PSD harassed MRND supporters. ${ }^{62}$ The CDR formed the Impuzamugambi, or "those with a single purpose," who also partook in the violence. ${ }^{683}$ The French had provided training to the Interahamwe and Impuzamugambi and was secretly supporting the CDR. ${ }^{684}$ The MDR attempted a broad approach to politics. They tried to recreate former president Kayibanda's Paramehutu party structure - thus igniting further north-south tensions with Habyarimana's MRND. ${ }^{685}$ Overall, the development of multiparty politics in Rwanda fueled societal tensions and provided the ground work for the transformation of youth wings into militias and ultimately genocidaires.

French military instructors were responsible for training the Rwandan military. They were reportedly "very lax" in screening the candidates they trained at military

\footnotetext{
${ }^{680}$ Desforges, Leave None to Tell the Story, p. 45.

${ }^{681}$ Henry Kwami Anyidoho, Guns over Kigali: The Rwandese Civil War-1994 (A Personal Account) (Accra New Town, Ghana: Fountain Publishers, 1998), p. 23

${ }^{682}$ Desforges, Leave None to Tell the Story, p. 46.

${ }^{683}$ Desforges, Leave None to Tell the Story, p. 46.

${ }^{684}$ Prunier, The Rwanda Crisis, p. 164.

${ }^{685}$ Prunier, The Rwanda Crisis, p. 122-124.
} 
installations. Prunier writes, "...the result was that, possibly without realizing it, the French trained MRND(D) and CDR militiamen, the notorious Interahamwe and Impuzamugambi who were later to organize and lead the April-May 1994 genocide." 686 This charge, which the French have always denied, gained tremendous momentum in Rwanda. So much so that French president Mitterrand was nicknamed "Mitterrahamwe." 687 The army was secretly providing more and more weapons to the Interahamwe and Impuzamugambi, who in turn were using these weapons to kill Tutsis, rival opponents, and settle personal grievances. ${ }^{688}$ The Rwandan military was receiving regular deliveries of arms and munitions. Rwandan service members were selling these on the local black-market so much that Prunier personally came across grenades for sale at a public market next to avocadoes and mangoes in June $1993 .{ }^{689}$ The Interahamwe and Impuzamugambi largely recruited from the poor who resided in or near the capital. These militias relied heavily on "street boys, rag-pickers, car-washers and homeless unemployed. For these people the genocide was the best thing that could ever happen to them. They had the blessings of a form of authority to take revenge on socially powerful people as long as these were on the wrong side of the political fence." ${ }^{690}$ In addition to taking orders, the extremist and hardline elements of the Interahamwe were freelancing

\footnotetext{
${ }^{686}$ Prunier, The Rwanda Crisis, p. 165, emphasis added.

${ }^{687}$ Prunier, The Rwanda Crisis, p. 165.

${ }^{688}$ Prunier, The Rwanda Crisis, p. 184.

${ }^{689}$ Prunier, The Rwanda Crisis, p. 184.

${ }^{690}$ Prunier, The Rwanda Crisis, p. 231-232.
} 
on their own. ${ }^{691}$ Settling scores and bringing violence on any who crossed them. And, during the genocide these perpetrators even murdered Tutsi women married to Hutus. According to one survivor's accounts, "The administration forced Hutu men to kill their Tutsi wives before they go to kill anyone else- to prove they were true Interahamwe." ${ }^{692}$ The sad truth is that everybody participated - men and women. Men partook in the killing while "cheering their men [on, women were] participating in auxiliary roles, like the second line in a street-to-street battle." ${ }^{.693}$

The main perpetrators of the genocide were ordinary Rwandan peasants. There were varying degrees of coercion exercised against ordinary Rwandans, but all efforts centered on one goal: to "kill the enemy Tutsi." ${ }^{694}$ To explain the extent of Rwanda's state-society coalition, we need to look no further than the wives of Interahamwe. This coalition was so vast that even these wives "had been reported to hit and beat Tutsi children on their way to fetch food and water." ${ }^{, 95}$ It is clear that even the wives of Interahamwe militiamen accepted Straus's idea of "collective ethnic categorization." In tying this all together, the final element that sealed the state-society coalition was the birth and ferocity of the Hutu Power movement. Hutu Power was a fringe movement in the 1980s but rose to prominence and became a mainstream ideology in the early

\footnotetext{
${ }^{691}$ Prunier, The Rwanda Crisis, p. 208.

${ }^{692}$ Mamdani, When Victims Become Killers, p. 4.

${ }^{693}$ Mamdani, When Victims Become Killers, p. 5.

${ }^{694}$ Prunier, The Rwanda Crisis, p. 247.

${ }^{695}$ Prunier, The Rwanda Crisis, p. 247.
} 
1990s. ${ }^{696}$ The idea of Hutu Power can be traced back to the 1959 social revolution where the notion of a "Hutu nation" emerged ${ }^{697}$ These ideas gradually drifted away under Habyarimana's "reconciliation" government of $1973 .{ }^{698}$ As Habyarimana's tenure endured and his prestige steadily declined Hutu Power filled the gap. Hutu Power advanced an age old génocidaire belief that Tutsis were "foreign" and "a race alien to Rwanda, and not an indigenous ethnic group." ${ }^{699}$ We have seen the same ideological beliefs propagated by the Nazis against the Jews and Roman, by the Turks against the Armenians, and the Burmese against the Rohingya Muslims. This movement eventually culminated with the publication of the Hutu Ten Commandments on December 10, 1990. ${ }^{700}$ These Ten Commandments forbade marriage, friendship, and the employment of

${ }^{696}$ Mamdani, When Victims Become Killers, p. 189.

${ }^{697}$ Mamdani, When Victims Become Killers, p. 189.

${ }^{698}$ Zachary A. Karazsia, "Developing Hearts and Land: A Case Study of Reconciliation, Governance, and Development in Rwanda," in Louis A. Picard, Terry F. Buss, Taylor B. Seybolt, and Macrina C. Lelei eds., Sustainable Development and Human Security in Africa: Governance as the Missing Link (Boca Raton, FL: CRC Press, 2015), pp. 233-248.

${ }^{699}$ Mamdani, When Victims Become Killers, p. 190.

700 The Hutu Ten Commandments

1. Every Muhutu should know that a Muhutu woman, wherever she is, works for the interest of her Tutsi ethnic group. As a result, we shall consider a traitor any Muhutu who:

- Marries a Tutsi woman;

- Befriends a Tutsi woman;

- Employs a Tutsi woman as a secretary or a concubine

2. Every Muhutu should know that our Hutu daughters are more suitable and conscientious in their role as woman, wife and mother of the family. Are they not beautiful, good secretaries and more honest?

3. Bahutu women, be vigilant and try to bring your husbands, brothers and sons back to reason.

4. Every Muhutu should know that every Mututsi is dishonest in business. His only aim is the supremacy of his ethnic group. As a result, any Muhutu who does the following is a traitor:

- Makes a partnership with Batutsi in business;

- Invests his money or the government's money in a Tutsi enterprise;

- Lends or borrows money from a Mututsi

- Gives favours to Batutsi in business (obtaining import licenses, bank loans, construction sites, public markets).

5. All strategic positions, political, administrative, economic, military and security should be entrusted to Bahutu. 
Tutsi women. They argued that Tutsis only sought ethnic supremacy of Hutus and should not be trusted. And, banned Tutsis from positions of power, the education sector, and the armed forces. In all this ideology empowered ordinary Hutu men and women to take action against Tutsis in their neighborhoods and watered the ground in preparation of the genocide.

\section{Cycle of Violence}

There are two approaches to examining Rwanda's cycle of violence. There are pros and cons to each. The first method takes historical Hutu-Tutsi intergroup conflict and violence into account. This approach draws on historically important periods in Rwandan history, such as the 1959 social revolution, the 1963 Tutsi pogrom, Habyarimana's ascension to power in 1973, and the 1990-1994 civil war and subsequent genocide. The second approach is more refined and merely begins analysis with the 1990 civil war. I prefer the former approach as it establishes the context in which Rwanda's mass political violence evolved.

6. The education sector (school pupils, students, teachers) must be majority Hutu.

7. The Rwandese armed forces should be exclusively Hutu. The experience of the October war has taught a lesson. No member of the military shall marry a Tutsi.

8. The Bahutu should stop having mercy on the Batutsi.

9. The Bahutu, wherever they are, must have unity and solidarity, and be concerned about the fate of their Hutu brothers:

- The Bahutu inside and outside Rwanda must constantly look for friends and allies for the Hutu cause, starting with their Bantu brothers;

- They must constantly counteract the Tutsi propaganda;

- $\quad$ The Bahutu must be firm and vigilant against their common Tutsi enemy.

10. The Social Revolution of 1959, the Referendum of 1961 and the Hutu Ideology must be taught to every Muhutu at every level. Every Hutu spread this ideology widely Any Muhutu who persecutes his brother Muhutu for having read, spread and taught this ideology is a traitor.

See Hugh McCullum, The Angels Have Left Us: The Rwanda Tragedy and the Churches (Geneva: WCC Publications, 1995, p. 114-115). 
Unlike Nazi Germany's hatred of the Jewish people which remained relatively consistent (and comprehensive) over time, anti-Tutsi sentiment "has never been a constant in Rwandan history." ${ }^{" 701}$ As illustrated above, the 1959 social revolution was a generational high point that reignited long standing intergroup tensions. ${ }^{702}$ The Bahutu Manifesto called for ethnic solidarity and was aimed at promoting a collective Hutu image. ${ }^{703}$ Any opponents of the social revolution were linked to "foreign enemies." This meant the Tutsi in Rwanda were viewed as enemies of the revolution and by extension the state while linked to Tutsi diaspora as spies (ibiyetso). This period also saw the elimination of moderate voices in the socio-political space, which further radicalized domestic politics. ${ }^{704}$

For all Habyarimana's faults, illegal actions, and ultimate contributions to genocide in Rwanda, when he seized power in 1973 he immediately worked to bring "peace and stability" to Rwanda. ${ }^{705}$ He outlawed political parties and subdued but not eliminating intergroup mass violence. At no point were Tutsis considered equal citizens or even permanent residents of Rwanda. Tutsis were forced from public and military service. Discriminated against in vast sectors of the economy. But, good "governance was conditioned on the ability of the Tutsis to submit to Habyarimana's rule and in

\footnotetext{
${ }^{701}$ Lemarchand, "Disconnecting the Threads," p. 504.

${ }^{702}$ René Lemarchand, Rwanda and Burundi (London: Pall Mall Press, 1970), p. 97.

${ }^{703}$ Lemarchand, Rwanda and Burundi, p. 149.

${ }^{704}$ Lemarchand, "Disconnecting the Threads," p. 504.

${ }^{705}$ Prunier, The Rwanda Crisis, p. 76.
} 
exchange they received a minimum level of security in lieu of state-directed violence. ${ }^{706}$ To be crystal clear, this was not an enjoyable or ideal situation for Tutsis. That said, it was nominally better circumstances then what they experienced a decade previously.

Between 1961 and 1966 there were as little as ten raids into Rwanda from Tutsi guerrilla fighters based in Burundi, referred to as inyenzi, or cockroaches by the Hutu regime. ${ }^{707}$ In 1962, after two successful raids which resulted in the death of three policemen, two public servants, and one Hutu civilian, the regime launched a reprisal attack and killed between 1,000 and 2,000 Tutsi men, women, and children, buried them in mass graves, and raided their homes and set them ablaze. ${ }^{708}$ The most successful "inyenzi" raid brought the fighters within 20 kilometers of Kigali. Sparkly widespread fears, the Hutu response was immediate and severe. This invasion, known today as the Bugesera invasion between November-December 1963, generated immediate reprisals by Hutu gangs and resulted in about 10,000 Tutsis massacred. ${ }^{709}$ Tensions remained between Hutus and Tutsis but were minimized under Habyarimana's rule until the late 1980s.

The Rwandan Patriotic Front launched its invasion from Uganda on October 1, 1990. By the time of the invasion Habyarimana was losing political influence and popularity among Rwandans but did not see the RPF as a major threat. ${ }^{710}$ Despite

\footnotetext{
${ }^{706}$ Karazsia, "Developing Hearts and Land,” p. 238.

707 Wm. Cyrus Reed, "Exile, Reform, and the Rise of the Rwandan Patriotic Front," Journal of Modern African Studies 34, 3 (1996), p. 481.

${ }^{708}$ Mamdani, When Victims Become Killers, p. 129.

${ }^{709}$ Reed, "Exile, Reform, and the Rise of the Rwandan Patriotic Front," p. 481.

${ }^{710}$ Desforges, Leave None to Tell the Story, p. 8.
} 
Habyarimana's private confidences, he and his regime publicly exaggerated the RPF threat as a means of solidifying his domestic power base. ${ }^{711}$ Along with the invasion, Habyarimana linked domestic Tutsi residents - who had no connection to the RPF other than ethnicity - as "ibyitso," or accomplices. ${ }^{712}$ This led to the further singling out of Tutsi through legal measures and social discrimination. Rwanda's population was and is overwhelming rural. In most villages residents knew who were Hutu, Tutsi, or of mixed heritage. In these small, close knit communities no perpetrator needed to examine one's identity card. They already knew who was to be targeted and killed.

Habyarimana's reconciliatory tone of the 1970s had disappeared by the end of 1992. In its place he instigated attacks, and spurred the advancement of anti-Tutsi propaganda. Through his political savviness he was able to further drive a wedge between Hutu and Tutsi. ${ }^{713}$ As his fear of the RPF solidified he encouraged his supporters and the RTLMC radio station to attack the Tutsi "enemies" endorse Hutu Power propaganda. In response to the assassination of Rwanda's sister nation's president to the south - Burundi - in late 1993, the RTLMC took advantage of the Tutsi led assassination and presented similar fears to Rwandan audiences. ${ }^{714}$ Also during 1993 some of Habyarimana's subordinates worries that the Interahamwe were becoming unmanageable and proposed the development of a "civilian self-defense force."715 These militias were recruited

\footnotetext{
${ }^{711}$ Desforges, Leave None to Tell the Story, p. 8.

${ }^{712}$ Desforges, Leave None to Tell the Story, p. 8.

${ }^{713}$ Desforges, Leave None to Tell the Story, p. 8.

${ }^{714}$ Desforges, Leave None to Tell the Story, p. 9.

${ }^{715}$ Desforges, Leave None to Tell the Story, p. 9.
} 
through the administrative channels and not through the party, like the Interahamwe was. These new recruits received training by former soliders and police officers "who would direct them in attacking the enemy in their communities." ${ }^{" 716}$ Col. Théoneste Bagosora, chief of staff in the defense ministry at the time of the genocide, instructed all "civilian self-defense forces" to be given inexpensive arms like machetes, because supplying them all with firearms was deemed too costly. ${ }^{717}$ It was this decision by Bagosora that led to the much reported gruesome nature of Rwanda's genocide.

\section{$\underline{\text { Decision Point }}$}

Similar to the Holocaust, the decision point in Rwanda begins prior to the start of the genocide. In Rwanda, the assassination of Habyarimana on the evening of April 6, 1994 was the triggering event that sparked his minions and the Akazu into action. However, these agents of the genocide had a plan in place prior to April 6 that allowed for them to initiate at a moment's notice. Preparations for mass killing were well underway for some time by April 6. Lieutenant General Roméo Dallaire was the UN Force Commander of the United Nations Assistance Mission for Rwanda (UNAMIR) in 1993. Dallaire sent a now infamous cable to the UN Peacekeeping Headquarters on January 11, 1994 which has been retroactively termed the "genocide fax." In this fax Dallaire informed UN headquarters staff that he was “...put in contact with [an] informant by very very important government politician [who was] ... a top level trainer

\footnotetext{
${ }^{716}$ Desforges, Leave None to Tell the Story, p. 9.

${ }^{717}$ Desforges, Leave None to Tell the Story, p. 9.
} 
in the cadre of Interahamwe - armed militia of MRND." ${ }^{\text {718 }}$ Dallaire went on to say that the informant had admitted to training 1,700 Interahamwe militiamen in Rwandan military camps, just outside Kigali. He informed Dallaire that this contingent had been divided into groups of approximately 40 each and scattered throughout the capital. Dallaire subsequently informed New York that the primary mission of the Interahamwe was to register all Tutsi in Kigali and the informant suspected "...it is for their extermination. Example he gave [Dallaire speaking in reference to informant] was that in 20 minutes his personnel could kill up to 1,000 Tutsis." ${ }^{.719}$ With this cable alone, we can conclude that future perpetrators have planned on exterminating Tutsis for at least three months before Habyarimana's assassination, we still do not know who fired the missile that took down his airplane on the night of April 6. Some have suggested that the RPF organized the assassination but there is little evidence to support this accusation. ${ }^{720}$ Others have claimed it was Hutu extremists that organized the plot so they could use the ensuing crisis to launch their extermination campaign. Regardless of the exact culprits, what remains clear is that Hutu hardliners in the military and political space seized power and ordered one of the $20^{\text {th }}$ centuries most swiftly executed genocides.

By late March 1994, elite Hutu hardliners had announced their intentions to mass murder all Tutsis and any moderate Hutu politician and citizen that opposed

\footnotetext{
${ }^{718}$ Roméo Dallaire, “Outgoing Code Cable: Request for Protection for Informant," United Nations Assistance Mission for Rwanda, January 11, 1994, p. 1-2.

${ }^{719}$ Dallaire, "Request for Protection for Informant," p. 1-2.

${ }^{720}$ Hele Epstein, "Sources That Link RPF to Rwanda Plane Plot," September 20, 2017, The Guardian. URL: https://www.theguardian.com/world/2017/sep/20/sources-that-link-rpf-to-rwanda-plane-plot.
} 
Habyarimana and the Hutu Power ideology. ${ }^{721}$ This pronouncement when acted upon would break the Arusha Accords and allow for a re-ignition of the civil war with the RPF. Alison Desforges eloquently summarizes the final preparations for mass murder:

They had soldiers and militia ready to attack the targeted victims in the capital and in such outlying areas as Cyangugu in the southwest, Gisenyi in the northwest and Murambi in the northeast. But elsewhere they had not completed the arrangements. In the center of the country, they had successfully disseminated the doctrine of Hutu Power, but they were unsure how many ordinary people would transform that ideology into action. In other areas, particularly in the south, they had not won large numbers of supporters to the idea, far less organized them to implement it. ${ }^{722}$

At approximately 10:20pm on the evening of April 6 word had spread from UNAMIR personnel at Kigali International Airport that "there has been an explosion."723 Dallaire had initially thought his weapons cache had been blown up but soon learned the explosion was from a plane crash. It was assured and eventually confirmed that the plane was Habyarimana's own and ironic twist of fate had crashed into his very own presidential compound at Kanombe Camo located in the suburbs of Kigali. ${ }^{724}$ As news of the plane crash was broadcast on the RTLMC radio station, presidential guardsmen and Interahamwe loyalists lashed out in anger, "they headed straight for the homes of political

\footnotetext{
${ }^{721}$ Desforges, Leave None to Tell the Story, p. 9.

${ }^{722}$ Desforges, Leave None to Tell the Story, p. 9-10.

${ }^{723}$ Roméo Dallaire, Shake Hands with the Devil: The Failure of Humanity in Rwanda (New York: Carroll and Graf Publishers, 2005), p. 221.

${ }^{724}$ Anyidoho, Guns over Kigali, p. 20.
} 
opponents of the president's party and started mass killings.."725 The assassination of Habyarimana sparked an immediate call for mass murder of Tutsis in Kigali, which over the next few days quickly spread outwards to Rwanda's provinces Moreover, this crisis reignited the civil war with the RPF, who had a battalion stationed in Kigali to protect their politicians during the Arusha process.

Col. Bagosora, the army chief of staff, quickly stepped forward into the power vacuum created in the aftermath of Habyarimana's assassination and formed a crisis committee which oversaw the mass killings and construction of road blocks throughout Kigali. The RTLMC immediately began broadcasting hate speech and calls to deliberately kill Tutsis "to avenge the death of our president." ${ }^{\text {"726 }}$ As RTLMC had gained wide popularity in the preceding months, thousands of Rwandans heard these calls to action, and many answered. Politicians and local elites had previously disparaged RTLMC because:

The station was rowdy and used street language, there were disc jockeys, pop music and phone-ins. Sometimes the announcers were drunk, particularly Noël Hitimana, whose jokes became offensive, vulgar and crude. RTLMC was designed to apple to the unemployed, the delinquents, and the gangs of thigs in the militia. ${ }^{727}$

After April 6, no diplomat, politician, or bystander doubted the influence of RTLMC had over mobilizing Interahamwe and other perpetrators to kill. Announcers on

\footnotetext{
${ }^{725}$ Anyidoho, Guns over Kigali, p. 23.

${ }^{726}$ Prunier, The Rwanda Crisis, p. 224.

${ }^{727}$ Linda R. Melvern, A People Betrayed: The role of the West in Rwanda's genocide (London and New York: Zed Books, 2000), p. 70.
} 
RTLMC regularly said the war against the RPF and by extension all Tutsis could not be won by the military alone, “...it required the participation of the entire Rwandan population. In one telling broadcast after the genocide had started, an announcer said: 'Stand up, take action... without worrying about international opinion.",728 Just like Dallaire's informant warned, death lists were widely distributed to future perpetrators, including the presidential guard, Interahamwe, Impuzamugambi, and others. ${ }^{729}$ It is clear from the historical record and eyewitness accounts that these murders were not spontaneous outbursts in response to Habyarimana's death but part of a pre-planned effort to exterminate once and for all the Tutsis from Rwanda.

This mass political violence episode was not a product of "ancient tribal hatreds" as some have argued. Nor were perpetrators exclusively driven by poverty and economic collapse. ${ }^{730}$ This genocide was the result of a "deliberate choice of a modern elite to foster hatred and fear to keep itself in power."731 Like the leaders at the top, the managers, principal perpetrators, accomplices, and beneficiaries of the genocide were not sadists, monsters, or demons but simply put, "they were people who chose to do evil.",732 While individual motivations vary (see Straus 2006 for more details on perpetrator

\footnotetext{
${ }^{728}$ Melvern, A People Betrayed, p. 72.

${ }^{729}$ Prunier, The Rwanda Crisis, p. 224.

${ }^{730}$ Desforges, Leave None to Tell the Story, p. 6.

${ }^{731}$ Desforges, Leave None to Tell the Story, p. 6.

${ }^{732}$ Desforges, Leave None to Tell the Story, p. 6.
} 
motives) perpetrators relentlessly sought out Tutsis and murdered them en masse until the RPF drove them from power. ${ }^{733}$

We do not know the exact number of perpetrators who took part in the killing during 1994. There have been several attempts to estimate this figure. Straus conducted formal and informal interviews with perpetrators and senior government officials after the genocide. These government officials claimed there were three million perpetrators. ${ }^{734}$ Philip Gourevitch's book We wish to inform you that tomorrow we will be killed with our families, also supports this claim with his own interview of a presidential advisor. ${ }^{735}$ This figure likely over estimates the total number of perpetrators (including: leaders, managers, principal perpetrators, accomplices, and beneficiaries). According to UN and World Bank statistics, the population of Rwanda in 1994 was about seven million. ${ }^{736}$ If correct, this means about four out of every ten people were perpetrators in the genocide. Other observers have estimated that the real figure lies in the hundreds of thousands range. ${ }^{737}$ Jones argues that possibly only tens of thousands were implicated in

\footnotetext{
${ }^{733}$ The author spoke with several Tutsi survivors who communicated that while the genocidaires were driven from Rwanda in July 1994, they too conducted cross-border raids and targeted killings for years after the war had formally concluded.

${ }^{734}$ Scott Straus, "How many perpetrators were there in the Rwandan genocide? An estimate" Journal of Genocide Research 6:1 (2004), p. 85.

${ }^{735}$ Philip Gourevitch, We wish to inform you that tomorrow we will be killed with our families: Stories from Rwanda (New York: Farrar, Straus \& Giroux, 1998), p. 244.

736 "Outreach Programme on the Rwanda Genocide and the United Nations," The United Nations, URL: www.un.org/en/preventgenocide/rwanda/education/rwandagenocide.shtml; "Rwanda," The World Bank Data, URL: htpp:data.worldbank.org/counry/Rwanda?view=chart.

${ }^{737}$ Des Forges, A. (1999) Leave None to Tell the Story: Genocide in Rwanda (New York: Human Rights Watch). Mamdani, M. (2001) When Victims Become Killers: Colonialism, Nativism, and the Genocide in Rwanda (Princeton: Princeton University Press); Scherrer, C. (2002) Genocide and Crisis in Central Africa: Conflict Roots, Mass Violence, and Regional War (Westport, CT: Praeger); Waller, J. (2002) Becoming Evil: How Ordinary People Commit Genocide and Mass Killing (Oxford: Oxford University Press).
} 
killing. ${ }^{738}$ Jones performs a rudimentary calculation. If the low estimate of victim is correct (i.e., 500,000 killed) and each perpetrator on average killed 10 people, then over the course of the genocide there was likely 50,000 perpetrators. To date, Straus in a separate article from his seminal book goes through painstaking detail to systematically estimate how many perpetrators there were. He concludes that the number is most likely between 175,000 and 210,000 people. ${ }^{739}$ We may never know the precise number of perpetrators, but we do know that most of them were overwhelming ordinary Rwandans who chose to do evil things to Tutsis and any Hutu who stood up for them.

\section{The Victims}

Within one hundred days of Habyarimana's plane crash, about 75 percent of Tutsis in Rwanda were murdered. ${ }^{740}$ This would prove to be the twentieth century's most swiftly executed genocide. Most of the Tutsis who died were killed within the initial days and weeks of the genocide. Just within Kibuye Precture, located in the west and bordering Lake Kivu, we saw 2.5 percent of all people killed during the genocide, murdered within the first 24 hours. ${ }^{741}$ There was also variation in violence across provinces. By enlarge "the percentage of Tutsis killed in a prefecture as a function of all Tutsis killed is similar to the percentage of Tutsis living in a prefecture as a function of

\footnotetext{
${ }^{738}$ Jones, B. (2001) Peacemaking in Rwanda: The Dynamics of Failure (Boulder: Lynne Rienner).

${ }^{739}$ Straus, "How many perpetrators were there in the Rwandan genocide?" p. 94.

${ }^{740}$ Straus, The Order of Genocide, p. 41.

${ }^{741}$ Straus, The Order of Genocide, p. 57.
} 
all Tutsis in Rwanda. ${ }^{\not 42}$ Moreover there was fluctuations in when the violence occurred. In some principalities Hutus began immediately and in others the perpetrators waited one to two weeks. ${ }^{733}$ We may never know the exact number of people killed. Initial estimates placed the number at about a half million killed. ${ }^{744}$ Many scholars have since used 800,000 as a general marker of the civilian death toll, while others including the new post-genocide government placed the total death count closer to one million. ${ }^{745}$ Whether the number is 500,000 or one million the devastation left in the wake of perpetrator actions has been one of history's worst atrocities. We should not gage our outrage by the top-line number of civilian deaths but by the actions of perpetrators. Victims endured such cruelty, torture, and savagery that scholars like Mamdani have documented:

About forty-eight methods of torture were used countrywide. They ranged from burying people alive in graces they had dug up themselves, to cutting and opening wombs of pregnant mothers. People were quartered, impaled or roasted to death... [Quoting a survivor] 'In some cases, victims had to pay fabulous amounts of money to the killers for a quick death. ${ }^{746}$

Most analysis of the genocide that focus primarily on the national level tend to overlook regional variations (like Straus uncovered) and the gendered dynamics of

\footnotetext{
${ }^{742}$ Straus, The Order of Genocide, p. 53-54.

${ }^{743}$ Straus, The Order of Genocide, p. 55.

${ }^{744}$ Desforges, Leave None to Tell the Story, p. 6.

${ }^{745}$ Binaifer Nowrojee, Shattered Lives: Sexual Violence During the Rwandan Genocide and Its Aftermath (New York: Human Rights Watch, 1996), p. 12.

${ }^{746}$ Mamdani, When Victims Become Killers, p. 6.
} 
violence. By the time of the genocide, there were over a dozen newspapers that had exploited intergroup animosities. ${ }^{747}$ These newspapers had a relatively small readership that was mostly confined to the capital district. Transient workers from the countryside would bring these papers to their home communities over the weekend. The periodicals regularly "printed graphic cartoons to portray Tutsi women using their supposed sexual prowess on U.N. Peacekeepers... and [sic] moderate Prime Minister Agathe Uwilingiyimana in various sexual posts with other politicians." ${ }^{, 748}$ When the genocide began rape of Tutsi women was widespread, in part, because of these gendered and ethnic stereotypes that portrayed Tutsi women as "beautiful and desirable, but inaccessible to Hutu men whom they allegedly looked down upon..."749

We may never know the exact number of women who faced widespread rape and abuse, but some observers believe that almost every woman who had survived the genocide was subject to this weapon of war. ${ }^{750}$ Rwandan culture, like many states around the globe stigmatizes sexual victimization and as a consequence this has kept women from reporting these incidents. ${ }^{751}$ According to the UN Special Rapporteur on Rwanda

\footnotetext{
${ }^{747}$ Nowrojee, Shattered Lives, p. 12.

${ }^{748}$ Nowrojee, Shattered Lives, p. 13.

${ }^{749}$ Nowrojee, Shattered Lives, p. 13.

${ }^{750}$ Nowrojee, Shattered Lives cites Catherine Bonnet, "Le viol des femmes survivantes du genocide du Rwanda," in Rwanda: Un genocide du XXe siècle, (Raymond Verdier, Emmanuel Decaux, Jean-Pierre Chrétien eds. (Paris: Editions L'Harmattan, 1995), p. 18.

${ }^{751}$ Christopher W. Mullins, “'We Are Going to Rape You and Taste Tutsi Women': Rape During the 1994 Rwandan Genocide" The British Journal of Criminology Vol 49. (2009), p. 725.
} 
René Degni-Segui, "rape was the rule and its absence the exception." "752 Christopher Mullins had identified three types of sexual victimization that occurred in 1994. The first were opportunist rapes, where individuals took advantage of the war and chaos. The second form was sexual enslavement, where women were held captive and repeatedly raped over an extended period of time. The third category of sexual violence was genocidal rapes, masses of perpetrators were ordered (or at minimum encouraged, teased, and pressured) to rape, humiliate and in some most gruesome encounters mutilated their victims. For those who protest the idea that rape can be used as an organized weapon of mass political violence, I highly suggest you read Carrie Sperling's article "Mother of Atrocities." In this influential work she notes that hundreds of patients in hospitals with AIDS were released and sent to rape women as "to cause slow, agonizing, painful deaths." 753 She reports that about two-thirds of genocide survivors are estimated to be HIV-positive from this organized sexual assault campaign.

Not only were women's experiences as victims of the genocide largely neglected by national accounts of the violence. So too was female involvement as perpetrators. Women played an active role as perpetrators in the genocide, but they have often been removed from the national discussion. ${ }^{754}$ Female perpetrators have been "depicted as

\footnotetext{
${ }^{752}$ United Nations, Report on the Situation of Human Rights in Rwanda submitted by Mr. René Degni-Segui, Special Rapporteur of the Commission on Human Rights, under paragraph 20 of the resolution \#-3/1 of 25 May 1994, E/CN.4/1996/68, January 29, 1996, p. 7.

${ }^{753}$ Carrie Sperling, "Mother of Atrocities: Pauline Nyiramasuhuko's Role in the Rwandan Genocide" Fordham Urban Law Journal Vol. 33, No. 2 (2006), p. 110.

${ }^{754}$ Sara E. Brown, "Female Perpetrators of the Rwandan Genocide," International Feminist Journal of Politics Vol. 16, No. 3 (2014), p. 448.
} 
deviant anomalies and stripped of their gender and humanity."755 Women were involved in direct and indirect means of violence. Jean Hatzfeld interviewed a prisoner after the genocide who said that "there were even healthy men who sent their wives to replace them for a day on the expeditions, but that didn't happen often because it was illegitimate." ${ }^{756}$ Beyond these cases, women were also implicated in indirect means of violence, that being, they exposed Tutsis in hiding, stealing, or looting for food. ${ }^{757}$ There was also "gender-specific mobilization" that fueled female perpetration of violence. One of the most influential mobilizing factors came from fear. For instance, Sara Brown reported, "One witness noted the sexual threat that Tutsi women represented led Hutu women to celebrate and encourage their mass killing: 'now these [Hutu] ladies were saying now we have husbands because these [Tutsi women] will be killed." "758 Another form of female perpetration of violence was a number of instances of women raping young Tutsi boys. One male victim of female-perpetrated gang rape recounted being drugged, stripped naked, undergoing sexual enslavement and being repeatedly raped by four women over the course of three days. ${ }^{759}$ This male survivor stressed that he was not alone in his suffering, but due to Rwandans' notion of masculinity, this crime has gone grossly underreported.

\footnotetext{
${ }^{755}$ Brown, "Female Perpetrators of the Rwandan Genocide," p. 449.

756 Jean Hatzfeld, Machete Season: The Killers in Rwanda Speak (New York: Farrar, Straus and Giroux, 2005), p. 73.

${ }^{757}$ Brown, "Female Perpetrators of the Rwandan Genocide," p. 449.

${ }^{758}$ Brown, "Female Perpetrators of the Rwandan Genocide," p. 457.

${ }^{759}$ Brown, "Female Perpetrators of the Rwandan Genocide," p. 459.
} 
Pauline Nyiramasuhuko was a high-profile female perpetrator. Pauline was associated with Madam Agathe Habyarimana, who supported her rise through the bureaucracy. ${ }^{760}$ After Habyarimana's assassination, Pauline was sent to Butare Prefecture to organize the genocide there for the interim government. She frequently incited Hutus to exterminate Tutsis and Hutu "accomplices" and provided these militias with the weapons to do it. ${ }^{761}$ It has even been reported that she had her son drive her around the prefecture and announced from a loud speaker that Tutsi men should be killed and their women raped and murdered. ${ }^{762}$ The role of women in Rwanda's 2994 genocide was complex. Women were both victims and perpetrators.

Let me conclude with a brief discussion of the only organized Tutsi defense during the genocide. This resistance took place in the hills surrounding Bisesero, which is a particularly mountainous area in western Rwanda. The killings took place between April and June 1994. The chance of survival for Rwandan Tutsis was extremely low, but because of Bisesero's high mountain ranges and organized defense, Tutsis in this area stood the best chance of survival. The first skirmishes took place within three days of Habyarimana's plane crash. The Hutu belligerents were largely peasants armed with traditional weapons. ${ }^{763}$ As the resistance stiffened Hutu genocidaires called in reinforcements who were from the army, Presidential Guard, militias, and other local

\footnotetext{
${ }^{760}$ Sperling, "Mother of Atrocities," p. 111.

${ }^{761}$ Sperling, "Mother of Atrocities," p. 112.

${ }^{762}$ Sperling, "Mother of Atrocities," p. 112-113.

${ }^{763}$ African Rights, with photographs by Jenny Matthews, Resisting Genocide: April-June 1994 (London: African Rights, 1997), p. 15.
} 
people. ${ }^{764}$ The attackers knew the victims by name and would call out to them as a form of verbal terrorism. They would also chant "Tubatsembatsembe," which translates to "eliminate them all." ${ }^{765}$ Because Bisesero was the only area of Rwanda with organized ad-hoc collective resistance, the perpetrators made Bisesero a top priority. They wanted to deprive the Tutsis of a pyric victory and avoid embarrassment from their inability to defeat this collective civilian force. After all these Tutsis were not trained for combat. They fought for weeks armed with rocks and stones. One survivor described the battle as "the war of stones against bullets." 766 The Tutsi employed a tactic called "merging," where they would lay flat on the ground and rise up at the very last minute to close ranks with the enemy so that the perpetrators could not use heavy weapons without fear of striking their own soldiers. ${ }^{767}$

Genocidaires became so incensed with the elusive nature of the Tutsi in Bisesero that when they captured and killed members of this group they would at times behead the victim o take to the local prefect, "so [he could] receive his reward." ${ }^{, 768}$ As the genocide wound down, there was a moment of hope for the approximate 2,000 survivors. Near the end of June, the French launched Operation Turquoise which on paper was to provide a "humanitarian protected zone" in south-western Rwanda. In reality the killing continued in this so-called protected zone. When French troops arrived at Bisesero, local militias

\footnotetext{
${ }^{764}$ African Rights, Resisting Genocide, p. 56.

${ }^{765}$ African Rights, Resisting Genocide, p. 15.

${ }^{766}$ African Rights, Resisting Genocide, p. 2.

${ }^{767}$ Desforges, Leave None to Tell the Story, p. 165.

${ }^{768}$ African Rights, Resisting Genocide, p. 56.
} 
were attempting to convince the French that this location was already safe. ${ }^{769}$ Then Tutsi survivors rushed too French and put forward their French translator to convince the soldiers that they were in danger. They showed their wounds and the corpses of dead neighbors. ${ }^{770}$ Either unconvinced, under orders, or out of neglect, the French reconnaissance force left the area and returned four days later. By the time they had returned, of the 2,000 survivors, only about 1,000 remained alive. ${ }^{771}$ At the beginning of the genocide about 50,000 men, women, and children gathered in the hills a top of Bisesero. By the end of major hostilities only 1,000 survived. Unfortunately for these survivors their nightmare was not over. Even once killing had largely seized French soldiers grew irritated with any Tutsi who wishes to return to RPF held territory. One survivor wrote, that after a French soldier heard his request to transfer " ...the attitude of the French soliders immediately changed, they became angry. They refused to give us any more food."772 Operation Turquoise should be a warning sign of the dangers in allowing state's with a vested interest in the domestic politics of a former client to conduct so-called "humanitarian" operations. No doubt lives could have been saved if humanitarian intervention took a different form.

\footnotetext{
${ }^{769}$ African Rights, Resisting Genocide, p. 61.

${ }^{770}$ African Rights, Resisting Genocide, p. 61-62.

${ }^{771}$ African Rights, Resisting Genocide, p. 62.

772 African Rights, Resisting Genocide, p. 63.
} 


\section{Conclusion}

The Holocaust and Rwandan genocides represent one of history's largest examples of mass political violence. Though each event is unique in its own right, they share similar conditions, tactics, and stratagems. There are four important conclusions that can be drawn from these two case studies. First, anti-group propaganda played an important role prior to the outbreak of mass violence. In each case periodicals were created to disperse disinformation about the target population. This distorted reality served to indoctrinate regime personnel and the masses. When the time came to exterminate all members of the victim group, individual perpetrators could rely on propaganda for encouragement and rationalization of their evil acts.

The second element used in these two state-society coalitions was an extensive dehumanization campaign. Both the Jews and Tutsis were viewed as "foreign" populations to the host country. Each group were compared to sub-human creatures like cockroaches or vermin. In both episodes' dehumanization came from the regime and from private organizations in society, thus giving the illusion of control in the dissemination of anti-group propaganda. Research shows that when individuals are exposed to dehumanized rhetoric overtime from a supra-individual entity (i.e., the state, military, or militia) and "feel controlled, they often respond by behaving in a less civilized, more antisocial manner."773 Moreover, research shows that dehumanization denies both perpetrator and victim an individual sense of identity and community. ${ }^{774}$

\footnotetext{
773 Arlen C. Moller and Edward L. Deci, "Interpersonal control, dehumanization, and violence: A selfdetermination theory perspective," Group Processes \& Intergroup Relations Vol. 13, Iss. 1 (2009), p. 41-53.

${ }^{774}$ Herbert G. Kelman, "Violence without Moral Restraint: Reflections on the Dehumanization of Victims and Victimizers," Journal of Social Issues Vol. 29, No. 4 (1973), p. 25-61.
} 
When perpetrators de-individualize their neighbors as was the case in Jedwabne, Poland and Bisesero, Rwanda, the victimizers are exceedingly more likely to enact violence and cruelty on their neighbors, because they are not viewed as equals (i.e., human beings) or individuals worth mercy.

A third important take away is the variation in how each state employed its regime power. Both Nazi Germany and Habyarimana's Rwanda were strong states. Germany was a totalitarian state. There were no limits on the power and authority of Hitler and his henchmen and women. Rwanda was not a totalitarian state, but it was strongly authoritarian. The distinction is important. While Habyarimana, the Akazu, the MRND, and the military had supreme rule, it was not absolute. A second variation between these two case studies is how the regime applied its power. In Germany, particularly towards the beginning of the war, mid-level bureaucrats retained a great deal of authority in how they accomplished the regime's goals. Eichmann's 1939 deportation project is one such example. It was neither approved by his superiors nor coordinated with local civilian authorities. Eichmann candidly took it upon himself to organize this experiment in savagery. In Rwanda genocidaires did not employ initiative in the same way as Eichmann. The order of the day was essentially to "search and destroy" all Tutsis. No mid-level bureaucrats changed or experimented in this gruesome task. The irony here is that while Germany maintained the stronger state system, its perpetrators were granted more unilateral authority than those in Rwanda.

Finally, there were also disparities in popular participation. When organized civilian militias or mobs engaged in violence against the Jews they did so with little attention or support of German forces. In these cases, it was relatively clear that the local 
Jewish populations posed no direct threat to the perpetrators and as such German officials allowed local peoples to brutally murder their neighbors. The societal support here was auxiliary and complimentary to German forces. In Rwanda, popular participation was essential to the effectiveness of the genocide. Without organized societal support the genocide would not have been nearly as catastrophic. In this case the social appetite for violence was equal to if not more important than the levers of the state in carrying out mass political violence. 


\section{CHAPTER VI: HIDDEN TRENDS: \\ STATE-SPONSORED GROUPS AND NON-STATE ACTORS}

\section{Introduction}

So far I have assessed the two dominant and historically prevalent types of mass political violence perpetrators - state perpetrators and state-society coalitions. These two categories have caused the most destruction of civilian populations in modern history. It is because of their severity in violence, that many, if not most Genocide Studies scholars have chosen to focus on these cases at the active or passive exclusion of lesser-known episodes of violence. Chapter six explores the final two categories of mass political violence perpetrators: state-sponsored groups and non-state actors. These groups may seem similar or even identical from an outsider's perspective. However, they are in fact conceptually and empirically distinct types. Section two unpacks the theory underpinning state-sponsored groups, which is followed by its application to three case studies. Section three assesses the dynamic structural approach to non-state actors and subsequently applies this theory to three relevant case studies. What follows is a discussion of historically marginalized and "hidden trends" in Genocide Studies research, that are becoming ever more important in the modern world.

\section{A Dynamic Structural Approach to State-Sponsored Groups}

Compared to state actors and state-society coalitions, state-sponsored groups have been a historically understudied topic within Genocide Studies. There has been much 
written about so-called "state-sponsored mass murder." 775 However, most authors use the term "state-sponsored" to reference mass violence that is primarily enacted by the state. Here I use the phrase "state-sponsored groups" to note mass political violence that is conceived by the state but carried out by sub-state or non-state armed groups (i.e., ethnic, religious, or political groups). These designated social groups implement violence on behalf of the state. These perpetrators may use a variety of tactics, including, mob violence, looting, slash-and-burn methods, or vigilantism against the regime's opponents. The primary difference in this category from state actors is that, the government lacks the appropriate resources or political will or determination to carry out violence on its own. Therefore, the government seeks assistance from social groups to kill on its behalf. This does not mean government soldiers will not partake in the violence. They are not the primary aggressors.

What is the existing polity structures of societies willing and able to use statesponsored mass political violence? Regime power is ranked from moderate too high. In these instances, the regime may control the capital, city, suburbs, and key municipalities across its land but it cannot exercise complete control over the population and territory. Therefore, regime power is moderate too high but geographically constrained to major municipalities. State capacity in these contexts is low. This is indicative of the fact that the regime is limited to specific areas. However, the restrictions of regime power and state capacity are aided by substantial support from organized social units. These social groups exist and support the regime's goals. They are eventually used as frontline

\footnotetext{
775 See, for example, Matthew Krain, "State-Sponsored Mass Murder" Journal of Conflict Resolution Vol. 41, No. 3 (1997), p. 331-360.
} 
perpetrators in the mass political violence of the regime. They may support the regime for a variety of reasons: a transactional association with the regime, perhaps an offer of greater regional autonomy post-conflict, or these groups may be ideologically aligned with the goals and objectives of the state. Regardless of the specific motive, what is clear, is that these social groups will become a central part of the ensuing violence.

Why might a government subcontract social groups to kill on its behalf? Beyond the limitations of its own authority and power, government agents may seek to preserve a semblance of anonymity or distance themselves from this state-orchestrated violence. There are many examples of states employing this clandestine military strategy. For instance, Russian president Vladimir Putin ordered elite Russian military units to capture the Crimean Peninsula from Ukraine in March $2014 .{ }^{776}$ These troops were called "highly organised local "self-defence groups" or "little green men." 777 According to the Russian government, these "self-defense groups" were organized by locals who took it upon themselves to purchase uniforms and hardware from "a shop." 778 By ordering these Russian soldiers to remove all insignia from their uniforms and to deny any association with the government, Putin's regime was able to distance themselves from this act of aggression. In this case the clandestine nature of the regime was not sufficient in distracting the international community and media from the true culprits. That said, it is a

\footnotetext{
${ }^{776}$ Daniel Treisman, "Why Putin Took Crimea: The Gamble in the Kremlin” Foreign Affairs May/June 2016. URL: https://www.foreignaffairs.com/articles/ukraine/2016-04-18/why-putin-took-crimea.

777 Vitaly Shevchenko, "Little Green Men" or "Russian Invaders"? BBC, March 11, 2014. URL: https://www.bbc.com/news/world-europe-26532154.

778 Vitaly Shevchenko, "Little Green Men" or "Russian Invaders"? BBC, March 11, 2014. URL: https://www.bbc.com/news/world-europe-26532154.
} 
prime example of why regimes distance themselves from groups. Secondly, Russia's annexation of Crimea and use of "little green men" were in fact government troops. When we apply this strategy to state-sponsored mass political violence, the "little green men" would be from a social group and not the national military.

Where would we see this kind of mass political violence? To reiterate and clarify, there are at minimum three specific circumstances that are conducive to state-sponsored groups. First, states where governmental and regime power has limited to no ability to govern all territorial provinces under its control. The second circumstance is in fragile, weak, or collapsed states experiencing conflict and violence. Finally, state-sponsored groups are likely to be used when the regime wishes to maintain an aura of international prestige and innocence and aims to side step public outrage and blowback from the principal perpetrators of violence.

What is the likely sustained killing capacity of state-sponsored groups? Due to the limitations explained above, I argue that state-sponsored groups as perpetrators of mass political violence are likely to be less severe in absolute terms of victim body counts, compared to state actors and state-society coalitions. The limitations on coordinating groups of perpetrators, inter-perpetrator group communication, and supply problems, and the clandestine nature of this type of violence all contribute to this moderate killing capacity.

Finally, who exactly are the perpetrators of mass political violence? The state and its regime elites remain the leaders in the hierarch of perpetrators (see Figure 3.1). The leaders are responsible for orchestrating and planning the actions of frontline personnel. The managers - the interlocutors between leaders and frontline perpetrators - are from 
the local groups who will enact violence. Finally, the principal perpetrators are from local or regional social, ethnic, political, religious, or mercenary groups. These frontline "troops" may be supported and/or directed by government forces. However, government troops are relegated to a supportive or coordination role.

\section{Brief Case Studies: State-Sponsored Groups}

\section{Massacres of Armenians in Ottoman Empire}

The first case study in state-sponsored groups took place in the Ottoman Empire during the late $19^{\text {th }}$ and early $20^{\text {th }}$ centuries. Throughout the Ottoman Empire, the regime used a variety of tactics and methods of mass political violence. This example is confined to the 1894-96 and 1909 massacres. The Ottoman socio-political system was divided into two “... antiethical entities: the ruling nation (millet hâkime) and the subject nation (millet mahküme). ${ }^{, 779}$ Central to this superior-inferior dichotomy was the Ottoman Islamic belief that the faithful (i.e., Muslims) were superior to the "infidels" (i.e., nonMuslims). ${ }^{780}$ This religious belief was ingrained in Ottoman law. Armenians were the dominant non-Muslim minority in Asia Minor. Their inferior and precarious status was exacerbated by the absolute denial of the right to bear arms. ${ }^{781}$ Finally, Ottoman minorities - the Armenians, Assyrians, and Greeks - operated many of the empire's

\footnotetext{
${ }^{779}$ Dinah L. Shelton ed., Encyclopedia of Genocide and Crimes Against Humanity (New York: Thomson Gale, 2005), p. 69.

${ }^{780}$ Shelton, Encyclopedia of Genocide and Crimes Against Humanity, p. 69.

${ }^{781}$ Shelton, Encyclopedia of Genocide and Crimes Against Humanity, p. 69.
} 
businesses and farms. Despite their essential function, "many of these populations were also subject to conditions tantamount to slavery on farms and plantations." ${ }^{, 782}$

At the national level, tensions between the Ottoman Turks and Armenians stemmed from "maladministration, mark by blight and ineptness," which increased the Armenians distressed conditioned. ${ }^{783}$ Outside interventionist responses "from Russia, England and France furthered the tensions.. ${ }^{1784}$ However, it was during these outside interventions that the Armenians were able to "jar themselves loose from the Ottoman yoke." ${ }^{, 785}$ Contrary to their sister groups in the Balkans, the Armenians initially did not want independence from the Sultan, but rather greater local autonomy. This call for greater local control over their lives grew into a nationalist-independence movement. ${ }^{786}$ Abdul Hamid II was the last Sultan of the Ottoman Empire. He was known as the "Great Assassin." ${ }^{787}$ Hamid consolidated power in the executive branch (his seat of power) within the constitutional monarchy. ${ }^{788}$ The weak institutional constraints on Hamid's monarchy "largely dissolved themselves" which soon gave way to an "unfettered autocracy" and eventually pure "despotism." 789 Hamid did not intervene on

\footnotetext{
${ }^{782}$ Hannibal Travis, Genocide in the Middle East: The Ottoman Empire, Iraq, and Sudan (Durham, NC: Carolina Academic Press, 2010), p. 174.

${ }^{783}$ Shelton, Encyclopedia of Genocide and Crimes Against Humanity, p. 70.

${ }^{784}$ Shelton, Encyclopedia of Genocide and Crimes Against Humanity, p. 70.

${ }^{785}$ Shelton, Encyclopedia of Genocide and Crimes Against Humanity, p. 70.

786 Travis, Genocide in the Middle East, p. 177.

${ }^{787}$ Shelton, Encyclopedia of Genocide and Crimes Against Humanity, p. 69.

${ }^{788}$ Shelton, Encyclopedia of Genocide and Crimes Against Humanity, p. 70.

${ }^{789}$ Shelton, Encyclopedia of Genocide and Crimes Against Humanity, p. 70.
} 
behalf of the Armenians during the massacres of 1894-1896. In fact, he implemented new Armenian policies that endorsed anti-Armenian persecution and state sanctioned violence. ${ }^{790}$ In the wake of these efforts the Armenian reform movement emerged and confronted the Ottoman regional and central governments. ${ }^{791}$

In anticipation of more conflict with the Armenian minority, Hamid established "an irregular force of pro-government Kurdish horsemen called the Hamidiye." ${ }^{, 92}$ By 1899 their numbers swelled from 33 to 63 regiments. ${ }^{793}$ These quasi-official regiments received ranks, uniforms, regimental badges, firearms, and with them, the license to intensify the level of persecution of the unarmed and highly vulnerable Armenian population..."794 These regiments played a key role in the 1894-96 massacres. Hannibal Travis compares the Hamidiye of Ottoman Turkey to the Janjaweed horsemen in Darfur, Sudan circa 2003-2005, an analogy worth noting. ${ }^{795}$ Many Kurdish leaders benefited from authority and public offices in the Ottoman regime. These elders used their official powers to "prey upon and oppress the country people," and inflict "innumerable oppressions and wrongs upon the Armenians and Assyrians." ${ }^{.796}$ French Ambassador Paul Cambon wrote the Ottoman government had "for the last few years, been pursuing its

\footnotetext{
${ }^{790}$ Shelton, Encyclopedia of Genocide and Crimes Against Humanity, p. 70.

${ }^{791}$ Shelton, Encyclopedia of Genocide and Crimes Against Humanity, p. 71.

${ }^{792}$ Travis, Genocide in the Middle East, p. 179.

${ }^{793}$ Shelton, Encyclopedia of Genocide and Crimes Against Humanity, p. 70.

${ }^{794}$ Shelton, Encyclopedia of Genocide and Crimes Against Humanity, p. 70.

${ }^{795}$ Travis, Genocide in the Middle East, p. 179.

${ }^{796}$ Travis, Genocide in the Middle East, p. 179.
} 
goals of gradually annihilating the Christian element... giving the Kurdish chieftains carte blanche to do whatever they please to enrich themselves at the Christians “expense."797

Sultan Hamid II initiated an empire-wide plan to massacre Armenians that lasted two years (circa 1894-1896). This vast effort claimed between 250,000 and 300,000 lives from both direct and indirect methods of violence. ${ }^{798}$ The perpetrators used "special cudgels or sticks that were fitted with a piece of iron" to inflict great bodily trauma on their victims. ${ }^{799}$ There was also organized popular participation in these massacres that were led by Mullahs on Fridays during "special religious services." ${ }^{800}$ Moreover, in some towns convicts were temporarily released from prison "for massacre duty" against Armenian civilians. ${ }^{801}$ These massacres were clearly orchestrated by agents of the state. Nearly all perpetrators were spared legal prosecution and punishment, thereby confirming once again the nature of state-sponsored mass political violence.

In addition to the 1894-1896 empire-wide massacres, the 1909 Adana massacre of Armenians is yet another example of state-sponsored groups mass political violence. Adana was a major city of the Vilayet in southern Turkey. ${ }^{802}$ Some 25,000 Armenians

\footnotetext{
${ }^{797}$ Travis, Genocide in the Middle East, p. 180.

${ }^{798}$ Shelton, Encyclopedia of Genocide and Crimes Against Humanity, p. 71.

${ }^{799}$ Shelton, Encyclopedia of Genocide and Crimes Against Humanity, p. 71.

${ }^{800}$ Shelton, Encyclopedia of Genocide and Crimes Against Humanity, p. 71.

${ }^{801}$ Shelton, Encyclopedia of Genocide and Crimes Against Humanity, p. 71.

${ }^{802}$ George Weissman and Duncan Williams eds., The Balkan Wars 1912-13: The War Correspondence of Leon Trotsky (New York: Monad Press, 1980), p. 457.
} 
fell victim to this bloodbath of violence. ${ }^{803}$ Dinah Shelton writes, “...the level of fiendishness and ferocity of which exceeded those of all other episodes of mass murder against the Armenians, including the World War I genocide." 804 What factors led to this hellish nightmare that so many Armenian men, women, and children faced? One contributing factor was the wealth accumulated by Armenian survivors of the 1894-1896 massacres served as a catalyst for intrepid perpetrators in $1909 .{ }^{805}$ Some Armenians espoused "aggressive" nationalist rhetoric which contributed to the polarization of Ottoman Turks and Armenians. This rhetoric fueled intergroup conflict and fed national narratives. Finally, there were large numbers of people who identified with the monarchy, local religious and military leaders who enthusiastically joined in the violence once it had begun. Their personal and socio-political bonds to perpetrators helped to swell their ranks and recruit likeminded "soldiers" for this intense massacre.

There is no question that the massacres of the late $19^{\text {th }}$ and early $20^{\text {th }}$ centuries were "centrally directed" by Sultan Hamid II and the subsequent Young Turks. ${ }^{806}$ The key question here is what makes these mass political violence episodes conceptually and empirically different from state-led mass political violence? One crucial element is the reliance on third-party organizations to implement and carryout these savage massacres of Armenians. The use of third-party organizations for this purpose is further flushed out in the next two case studies.

\footnotetext{
${ }^{803}$ Shelton, Encyclopedia of Genocide and Crimes Against Humanity, p. 72.

${ }^{804}$ Shelton, Encyclopedia of Genocide and Crimes Against Humanity, p. 72.

${ }^{805}$ Shelton, Encyclopedia of Genocide and Crimes Against Humanity, p. 72.

${ }^{806}$ Shelton, Encyclopedia of Genocide and Crimes Against Humanity, p. 72.
} 


\section{The 1960s "Congo Crisis"}

As witnessed in the Ottoman Empire, state-sponsored groups can take the form of organized militiamen who are given military rank, uniforms, and a quasi-official status. However, this avenue of state-sponsored group perpetrators requires more than a little but not quite substantial recruitment, coordination, oversight, and planning by governmental officials. There is another approach available to regimes in this predicament. It is less expensive, at least in terms of direct government oversight. States may hire mercenaries or as we have come to call them "private security companies" to do their bidding. ${ }^{807}$ Patrick Baker writes, "Mercenaries have existed as long as organized armies have existed, they have been despised and denigrate. Aristotle wrote of them, as did Machiavelli." ${ }^{808}$ Baker is correct, mercenary armies were the mainstay in antiquity where standing and ad-hoc armies would be comprised of individuals seeking financial or personal gain. The benefit of these "armies" to the state lie in their ability to assemble quickly and support the usually meager internal security forces.

There are two types of mercenaries. The first is a traditional soldier, individual or group that is for hire. They may be hired to supplement existing standing armies. They might be hired for their expertise in a given area. Or, they may be hired to preserve anonymity and plausible deniability on behalf of the state. The second type of mercenary is what some may call "the soldier of fortune." These soldiers belong to a well-organized,

\footnotetext{
${ }^{807}$ Zachary Karazsia, "Peace Inc? The Role of Contractors in International Peace Operations" Ford Institute for Human Security, University of Pittsburgh, April 11, 2012, p. 1.

${ }^{808}$ Patrick S. Baker, "Mercenaries and the Congo Crisis,” Saber and Scroll Vol. 2, Iss. 1 (2013), pp. 89.
} 
hierarchical structure, unified and run as a corporation. In fact, they are legally registered corporations. Academi is one such company, though most know them by their former name, Blackwater. Erick Prince, a former navy seal team member, founded the company in the late 1990s. Blackwater was heavily criticized for its role in the 2003 Iraq War. But there are many companies around the globe that can perform the same duties (and deserve the same attention) as Blackwater. For example, ICTS International N.V. is an Israeli owned and operated company; Northbridge Security Group is registered in the Dominican Republic but operates branch offices in the U.S., U.K., and Ukraine; AEGIS Defense Services is a British private security company; so is KBR, however KBR has expanded its focus to also include engineering and construction services and is based in the U.S.; and the list goes on and on. It is no surprise that corporate security forms hate being lumped in with "traditional" mercenaries. From their perspective private security corporations provide "vital services in conflict, post-conflict, and disaster relief operations." ${ }^{809}$ For clarity in understanding, I use H.C. Burmester's conceptualization of mercenaries: “...A mercenary [is] a volunteer who, for monetary reward, enters into an agreement to fight for the armed forces belonging to a foreign state or an entity purporting to exercise authority over a country or people or a part thereof." ${ }^{\prime 10}$

The so-called "Congo Crisis" is an example of state-sponsored groups as mercenaries. On June 30, 1960 Congo-Kinshasa gained independence from Belgium. Soon after independence, Congo experienced severe socio-political chaos, which has

\footnotetext{
${ }^{809}$ Karazsia, "Peace Inc?” p. 1-2.

${ }^{810}$ H. C. Burmester, "The Recruitment and Use of Mercenaries in Armed Conflicts," The American Journal of International Law Vol. 72, No. 1 (Jan. 1978), pp. 37.
} 
become known as the "Congo Crisis." Lazlo P.C. Passemiers eloquently defines the "crisis" as “...a power struggle over who was most suitable and entitled to administer and control Congo, and what political model and ideological trajectory the newly independent state should follow." 811 The crisis began as "sporadic bursts of localized violence and protest" during the immediate aftermath of independence. ${ }^{812}$ This localized violence snowballed into widespread chaos that led to the secession of Katanga Province and South Kasai. Beyond national domestic violence, Congo was soon to be another proxy battle of the Cold War rivalry. A U.N. peacekeeping mission was authorized after Congo's first democratically elected Prime Minister Patrice Lumumba was assassinated. This mission led to "the emergency of the popular Kwilu and eastern rebellions; and the enlistment of a large contingent of foreign white mercenaries." ${ }^{813}$

The secession of Katanga Province was a major milestone in the escalation of violence. Katanga's governor Moïse Tshombe declared independence from Congo on July 11, 1960. Tshombe earned immediate support from the Katangese Mining Company and Belgium. ${ }^{814}$ During this two-year long uprising, Tshombe relied on three sources for armed support. He used rural youth groups in north Katanga, gendarmerie, and beginning in "January 1961 [Tshombe] had reinforced [these troops] ... with white mercenaries from Belgium, France, South Africa, and Rhodesia." ${ }^{815}$ As hypothesized, Tshombe relied

\footnotetext{
811 Lazlo Patrick Christian Passemiers, "South Africa and the 'Congo Crisis', 1960-1965" (doctoral dissertation, The University of the Free State, 2016), p. 1.

${ }^{812}$ Passemiers, "South Africa and the "Congo Crisis"”, p. 1.

${ }^{813}$ Passemiers, "South Africa and the 'Congo Crisis", p. 1.

${ }^{814}$ Passemiers, "South Africa and the 'Congo Crisis", p. 287.

${ }^{815}$ Passemiers, "South Africa and the 'Congo Crisis"', p. 33.
} 
on mercenaries - principally from South Africa and Rhodesia - as a last resort. ${ }^{816}$

Tshombe lacked the resources to wage this violence and secessionist movement on his own. As Passemiers notes, Tshombe was well aware of the political repercussions in using (white) mercenaries to do his dirty work, but his view was that he had no other choice than to risk damaging his public image. ${ }^{817}$ There was vast intergovernmental exchanges between Western and African nations over the question of supporting Katanga. The U.S. approached Belgium to enquire if they would send troops to calm the situation and provide security. Belgium ultimately declined to send frontline troops but did increase its military technical advisors. ${ }^{818}$ Tshombe reached out to the governments in Senegal, Ethiopia, and Nigeria for assistance but his overtures were rebuffed. Once these avenues were closed he was "forced to rely on a white mercenary force. Brussels and Washington supplied the necessary finances and equipment to make this force operational." 819

There has not been extensive scholarly analysis of the mercenaries involved in the Congo Crisis. According to Passemiers most of the literature has been rooted in "unacademic" and "biased" approaches. The majority of work on this topic has relied on the personal accounts of ex-mercenaries to describe the conflict - thus undoubtedly skewing the reporting in favor of them. ${ }^{820}$ The decision to use mercenaries as a state-sponsored

\footnotetext{
${ }^{816}$ Passemiers, "South Africa and the 'Congo Crisis"”, p. 41.

${ }^{817}$ Passemiers, "South Africa and the 'Congo Crisis", , p. 41.

${ }^{818}$ Passemiers, "South Africa and the "Congo Crisis"”, p. 41.

${ }^{819}$ Passemiers, "South Africa and the 'Congo Crisis"”, p. 41.

${ }^{820}$ Passemiers, "South Africa and the "Congo Crisis", p. 8; For more on mercenary's personal accounts see Michael Hoare's The Road to Kalamata: A Congo Mercenary’s Personal Memoir and Congo Mercenary;
} 
group beholden to Tshombe was a decision made out of principally domestic factors.

That said, the government of South Africa allowed its citizens to be recruited and funneled to Katanga so that "Pretoria... [could] test international reactions as well as its own capacity to fill the vacuum which had resulted from the withdrawal of the European powers." 821 Stephen Clarke argues that the use of South African mercenaries was a "symbolic marker" used by the South African government to preserve white apartheid role over the region. ${ }^{822}$ It is clear Tshombe's decision to use mercenaries had exogenous effects and benefited other countries, but that does not minimize their use in Congo.

The government of Katanga made three types of requests to South Africa.

Tshombe wanted South Africa and other (African and non-African) nations to recognize Katanga's independence, engage in commerce and trade, and with special emphasis on South Africa to supply arms and munitions. ${ }^{823}$ Katanga used South Africa as a

Hans Germani's, White Soldiers in Black Africa: Related from His Own Experiences; Jerry Puren's, Mercenary Commander; and Ivan Smith's, Mad Dog Killers: The Story of a Congo Mercenary.

821 Stephen Clarke's The Congo Mercenary: A History and Analysis (Johannesburg: The South African Institute of International Affairs, 1968), p. 35.

822 "According to the secondary literature, Pretoria knew about the South African mercenaries in Congo, and various government departments had covert contact with them.” Jerry Puren and Brian Pottinger, Mercenary Commander: Col Jerry Puren as Told by Brian Pottinger (Alberton: Galago, 1986), p. 196.

There are also allegations that members of the South African Defense Force infiltrated the mercenary force, and that Pretoria supplied military equipment to the Katangese government and later to the Central Congolese government. Passemiers, "South Africa and the "Congo Crisis",, p. 41; Mockler, The Mercenaries, p. 223; Gleijeses, 'Flee! The White Giants Are Coming!', p. 224; Andrew Cohen, 'A Difficult, Tedious and Unwanted Task': Representing the Central African Federation in the United Nations, 19601963', Itinerario, 34, 2 (August 2010), pp. 112- 113; Hughes, The Central African Federation, Katanga and the Congo Crisis, pp. 2; 34.

"Such brief references in the literature were never further investigated or corroborated, leaving much of Pretoria's controversial involvement in the Congo crisis shrouded in mystery." Passemiers, "South Africa and the "Congo Crisis"', p. 10.

${ }^{823}$ Passemiers, "South Africa and the "Congo Crisis"”, p. 73. 
commercial hob for importing goods and disguising weapons as goods for delivery. ${ }^{824}$ There were reports of non-sanctioned aircraft flying to and from Katana-South Africa. It is speculated that these likely carried goods that were meant to stay off the political radar and support Tshombe's movement. However, South Africa was not a complete “openborder" ally for Katanga. Despite much arms begin sent to South Africa and funneled to Katanga via Angola, the South African government did intervene to stop several "questionable material" in transit. ${ }^{825}$ It is likely the government performed these interdiction measures to combat international accusations by U.N. member states that linked South Africa to Katanga rebels. ${ }^{826}$ Therefore, secrecy was key on behalf of both parties.

We understand Tshombe's goals vis-à-vis the regional hegemon. Why might South Africa choose to support and aid or at minimum allow those within their borders to support and aid Katanga? Just briefly, there may be three such reasons. First, South Africa remained an apartheid state and as such did not support the decolonization of Congo. The white minority government wanted to avoid "the emergence of a black Congolese government." ${ }^{827}$ Belgium and South Africa did not enjoy amicable diplomatic relations before decolonization, and the governments had no such hope of improvements after independence. Tension with former colonial overlords and now independence African states were a constant source of frustration and anxiety for South Africa. The

\footnotetext{
${ }^{824}$ Passemiers, "South Africa and the 'Congo Crisis"”, p. 75.

${ }^{825}$ Passemiers, "South Africa and the 'Congo Crisis", p. 76.

${ }^{826}$ Passemiers, "South Africa and the 'Congo Crisis"”, p. 76.

${ }^{827}$ Passemiers, "South Africa and the "Congo Crisis"”, p. 45.
} 
second possible motive of support would be to minimize refugee/migrant flows southward.

There were concerns that a considerable number of refugees on the copper belt would want to immigrate to South Africa, but [South Africa's High Commissioner in Salisbury, Harold Taswell] warned that many of them were not of the most desirable type. These undesirable refugees were mostly Greek, Maltese, Cypriot, and Italians, noting that many of them look like the real ducktail type. ${ }^{828}$

Finally, as has been the motivation for many decades, if not centuries, the government wanted access to Katanga's rich mineral reserves. ${ }^{829}$ All considered, these are three possible motivations behind South Africa's track-two support for Tshombe's secessionist government.

Based on the available record, the first point of contact between Katanga and South African mercenaries dates back to August $1960 .{ }^{830}$ Further mercenary recruitment occurred in January 1961 - which sought support in France and Belgium. ${ }^{831}$ And, recruitment picked up in March 1961, with many South Africans joining the call. As discussed, the government in Pretoria was not directly involved in the recruitment process but "it was certainly well aware of it." 832 According to the literature, there is no record of any instance where the South African government prevented an individual from

\footnotetext{
${ }^{828}$ Passemiers, "South Africa and the 'Congo Crisis"”, p. 59.

${ }^{829}$ Passemiers, "South Africa and the 'Congo Crisis"”, p. 66.

${ }^{830}$ Passemiers, "South Africa and the 'Congo Crisis"”, p. 78.

${ }^{831}$ Clarke, The Congo Mercenary, p. 27-28.

${ }^{832}$ Passemiers, "South Africa and the "Congo Crisis"”, p. 80.
} 
joining the Katanga mercenary force ${ }^{833}$ These men would eventually form the bulk of $\mathrm{V}$ Commando that was deployed in the northern Katanga region. ${ }^{834}$

The "Congo Crisis" was not confined to Katanga. There were rebellions in the east too. First, the Mulelists uprising and revolt was led by a former minister of the deceased prime minister's cabinet, Pierre Mulele. ${ }^{835}$ Mulele initiated his revolt after returning from Communist China in 1963. The Mulelists would not achieve any "major military victory" but nonetheless have caused between 60,000 and 100,000 deaths. ${ }^{836} \mathrm{~A}$ second rebellious group called the Simbas, launched a revolt in July 1964. On July 21 the Simbas took the city of Kindu and then captured Stanleyville, Congo's third largest city, on August $4{ }^{837}$ In a shocking surprise to all, the Simbas gained control of more than onethird of Congo. ${ }^{838}$ The Simbas were largely composed of random groups of fighters who were not trained soldiers. ${ }^{839}$ These men were “...especially ill disciplined. Acts of fetishism and witchcraft were widespread in their ranks, and as their defeats accumulated their previously good relations with local population[s] deteriorated." 840

\footnotetext{
${ }^{833}$ Passemiers, "South Africa and the 'Congo Crisis"”, p. 81.

${ }^{834}$ Passemiers, "South Africa and the 'Congo Crisis"', p. 111.

${ }^{835}$ Ludo De Witte, "The suppression of the Congo rebellions and the rise of Mobutu, 1963-5," The International History Review Vol. 39, No. 1 (2017), pp. 110.

${ }^{836}$ De Witte, "The suppression of the Congo rebellions and the rise of Mobutu," p. 110.

${ }^{837}$ De Witte, "The suppression of the Congo rebellions and the rise of Mobutu," p. 110.

${ }^{838}$ De Witte, "The suppression of the Congo rebellions and the rise of Mobutu," p. 110.

${ }^{839}$ De Witte, "The suppression of the Congo rebellions and the rise of Mobutu," p. 114.

${ }^{840}$ De Witte, "The suppression of the Congo rebellions and the rise of Mobutu," p. 114.
} 
Let me briefly say another word on external involvement in the Congo Crisis.

Piero Gleijeses quotes Carl Rowan, a former director of the U.S. Information Agency in his article "“Flee! The White Giants Are Coming!"” as writing in a memorandum to the president:

A real danger that in saving the present situation in the Congo we... could lose the longer range struggle for all of Africa. I am particularly concerned about the damaging implications of possible press reports that United States' planes are hauling Belgian guns to be used by South African and Southern Rhodesian mercenaries to kill Africans and to protect Tshombe and European financial interests. ${ }^{841}$

The U.S. Ambassador to Congo said of the mercenaries, “... [they are] an uncontrollable lot of toughs... who considered looting or safecracking fully within their prerogatives." $\$ 42$ Finally, there is no record of any U.S. official disagreeing with Katanga's use of mercenaries. They only noted that their deployment in Congo would constitute a "pyrrhic [victory] if it caused a backlash in Africa or at home." ${ }^{, 843}$

By 1963 Tshombe's effort to secure an independent Katangese state had collapsed. In 1964 Tshombe became prime minister in Congo under a nationally unified government. Here Tshombe "looked to recruit [again] a mercenary force to bolster the military position. Under the direction of South African Mike Hoare, a mercenary army was rapidly assembled." ${ }^{844}$ Whether leading the Katanga independence movement or Congo writ large, Tshombe was an advocate of state-sponsored mercenary groups. So

\footnotetext{
${ }^{841}$ Piero Gleijeses, “'Flee! The White Giants Are Coming!': The United States, the Mercenaries, and the Congo, 1964-65” Diplomatic History Vol. 18, No. 2 (2007), pp. 207-237.

${ }^{842}$ Gleijeses, “"Flee! The White Giants Are Coming!’” p. 218.

${ }^{843}$ Gleijeses, “"Flee! The White Giants Are Coming!”” p. 222.

${ }^{844}$ De Witte, "The suppression of the Congo rebellions and the rise of Mobutu," p. 111.
} 
much so that by mid-1964 Hoare's mercenary force had recruited dozens of South African, Rhodesian, Belgian, Italian, and German fighters. ${ }^{845}$

Recall that the Simbas captured Stanleyville for an extended period of time. After 111 days of occupation, the Congolese mercenaries launched an operation to retake control of the city, called "Operation Red Dragon." 846 The attack was two-pronged. Belgian paratroopers were flown in and dropped over the city while the mercenary force named "Ommegang," or the parade, charged over land. ${ }^{847}$ There are many stories of the Ommegang's brutality, including rape and murder. ${ }^{848}$ The Observer publication covered the atrocities. Ludo De Witte writes, "One image shows [in The Observer] a group of mercenaries arguing about who was going to hang two Africans. Other images showed executions by firing squad and hangings of prisoners. Some African prisoners were even used for target practice." 849 When the final attack commenced, the Belgian troops seized control of the city center and Ommegang approached from the exterior. Once Ommegang entered the city, "a massacre ensued." 850 The victims of these atrocities did include the Simbas, rebels writ large, Mulelists, and other insurgents, "but in reality the victims were very often ordinary inhabitants of the city." ${ }^{851}$ Belgian press reported on this nightmarish

\footnotetext{
${ }^{845}$ De Witte, "The suppression of the Congo rebellions and the rise of Mobutu," p. 111.

${ }^{846}$ De Witte, “The suppression of the Congo rebellions and the rise of Mobutu," p. 118.

${ }^{847}$ De Witte, “The suppression of the Congo rebellions and the rise of Mobutu," p. 118.

${ }^{848}$ De Witte, “The suppression of the Congo rebellions and the rise of Mobutu," p. 116.

${ }^{849}$ De Witte cites "Escale a Léo" [A Visit to Leo] Jeune Afrique, August 8, 1965, p. 19 in De Witte, "The suppression of the Congo rebellions and the rise of Mobutu," p. 116.

${ }^{850}$ De Witte, “The suppression of the Congo rebellions and the rise of Mobutu,” p. 118.

${ }^{851}$ De Witte, "The suppression of the Congo rebellions and the rise of Mobutu," p. 118.
} 
situation, saying "the inhabitants of Stanleyville are going into hiding and they are right to do so. Black citizens that dare to show themselves in the streets risk their lives. Simbas or not, any and all Africans were targeted." ${ }^{" 552}$ There was undoubtedly a racial component. To celebrate their "victory" mercenaries committed crimes, looted, plundered, and raped the city. The perpetrators were nearly all white. ${ }^{853}$

Despite all the atrocities endured during the capture of Stanleyville, the real horrors came a week later. After Belgian troops left, any restraint that had been exercised over the Ommegang evaporated. It was upon their Belgian compatriots' departure that the mercenaries began to systematically "cleanse" the city. ${ }^{854}$ In a blatant effort demonstrating their plans, mercenaries' setup a perimeter around the city to establish a secure killing zone. ${ }^{855}$ Victor Nendaka, who had previously formed "security squads" in 1960, used these troops to assist the mercenaries in their killings. There were 50,000 people who had gathered in a stadium. The perpetrators systematically identified Simbas and their supporters. According to reports, the actions of perpetrators were so gruesome that most personal accounts did not go into the details. Here the Nendaka "security squads," more accurately termed "killing squads" performed the vast amount of violence while the other white mercenaries "relieve[d] the wounded from their suffering by

\footnotetext{
${ }^{852}$ De Witte, "The suppression of the Congo rebellions and the rise of Mobutu," p. 118.

${ }^{853}$ De Witte, "The suppression of the Congo rebellions and the rise of Mobutu," p. 119.

${ }^{854}$ De Witte, "The suppression of the Congo rebellions and the rise of Mobutu," p. 108.

${ }^{855}$ De Witte, "The suppression of the Congo rebellions and the rise of Mobutu," p. 108.
} 
finishing them off while the Congolese took great satisfaction in seeing their opponents suffer and die slowly." 856

The Congo Crisis is somewhat a misnomer, it should be named the Congo Crises to better explore the multifaceted, complex nature of violence. Beyond the assassination of Congo's first democratically elected prime minister, casualty figures include the various secession movements and rebellions. There is a combined estimate of between 138,045 and 264,800 deaths attributed to all crises. ${ }^{857}$ Establishing clear victim thresholds is difficult. However, one can reliably conclude the victim casualties were greater than 10,000 within a 12 -month period. And, mercenaries were an instrument used by both domestic and international actors. It is clear that their involvement in Congo contributed to a higher death toll.

\section{$\underline{\text { Mass Political Violence and Genocide in Darfur }}$}

At the time of the Darfurian rebellion and mass political violence, Sudan was the largest country in Africa. Darfur has long been a marginalized province. The Darfurian people were neglected long before Sudan became independent. This policy of neglect dated back to British colonial rule. In January 2003, the Sudanese Liberation Army/Movement (SLM) and the Justice and Equality Movement (JEM) launched attacks on crucial military outposts. ${ }^{858}$ The SLM and JEM insurgencies ignited a war for

\footnotetext{
${ }^{856}$ De Witte, "The suppression of the Congo rebellions and the rise of Mobutu," p. 119.

${ }^{857}$ Passemiers, "South Africa and the 'Congo Crisis"', p. 43.

${ }^{858}$ Noah R. Bassil, The Post-Colonial State and Civil War in Sudan (London and New York: I.B. Tauris, 2013), p. 3.
} 
independence and autonomy. By the middle of 2003, the Government of Sudan, led by president Omar Hassan al-Bashir, responded to the Darfurian rebel movements by ordering "a massive campaign of killing and expulsion [that was] carried out both by regular army troops [primarily in a support capacity] and by a proxy force known as the Janjaweed." ${ }^{859}$ Right from the beginning Khartoum's policy was one of death and destruction. There would be no negotiation, no truce, the Sudanese government would conquer and subdue the people of Darfur by any means necessary. This genocide is a classic example of "how a dominant center manages its peripheries." 860

Darfur had a history of armed movements vis-à-vis its internal relations and neighbors. In the 1980s to 1990s, the Sudanese People's Liberation Army (SPLA) had tried to "provoke an uprising in Darfur." ${ }^{861}$ One reason the SPLA wanted Darfurians to rebel was to create a unified front against the politicians in Khartoum, who had embraced an ideology of Arab supremacy over the western and southern Christians. ${ }^{862}$ Darfur's relative deprivation expounded with a drought and subsequent famine in the mid-1980s. As s these challenges were not enough, the Zaghawa, a Muslim ethnic group, had toppled the Chadian government in 1990 but were also very reluctant in directly confronting

\footnotetext{
${ }^{859}$ Debarati Guha-Sapir and Olivier Degomme, "Counting the Deaths in Darfur: Estimating mortality from multiple survey data," Households in Conflict Network, The Institute of Development Studies (Falmer, England: University of Sussex, 2006), p. 1.

${ }^{860}$ Alex de Waal, "Darfur's Elusive Peace," in Alex de Waal, ed., War in Darfur and the Search for Peace (Cambridge, MA: Global Equity Initiative, Harvard University, and Justice Africa, 2007), p. 368.

${ }^{861}$ Ali Haggar, "The Origins and Organization of the Janjawiid in Darfur," in Alex de Waal, ed., War in Darfur and the Search for Peace (Cambridge, MA: Global Equity Initiative, Harvard University, and Justice Africa, 2007), p. 142.

${ }^{862}$ Haggar, "The Origins and Organization of the Janjawiid in Darfur," p. 142.
} 
Khartoum. ${ }^{863}$ The immediate problem for the Zaghawa was fighting the Awlad Zeid Arab nomads who had fought the Zaghawa for years. Darfur's history of violence and restraint from attacking forces aligned with and of the government of Sudan was wearing thin by the early 2000s.

The modern Darfur rebel movement began to organize itself in 2001, just two years prior to the start of the rebellion. These small militia groups had "little more than weapons... for personal defense." ${ }^{864}$ Violent clashes between the Zaghawa and Awlad Zeid forces reached a point of no return in May 2001 when the latter group killed more than 70 Zaghawa at an important watering hole. ${ }^{865}$ In the aftermath, government forces deployed to the area forced the Zaghawa people away from this vital natural resource. This incident convinced many Zaghawa that their fight was not only with other local tribes but with the national government. Between 2001 and 2003 all competing rebel forces met and agreed to fight under a loose coalition. ${ }^{866}$ This confederation did not last long nor achieve much success. It was riddled with infighting and backstabbing. Eventually by 2002 the organizational structure was cemented. A member of the Fur group would be named chairman, a Zaghawa was to be the chief of staff, and a Masalit was the deputy chairman. ${ }^{867}$ Once the conflict reached a boiling point in 2003, the SLA and JEM led separate but sometimes coordinated attacker on the state and its state-

\footnotetext{
${ }^{863}$ Julie Flint, "Darfur's Armed Movements," in Alex de Waal, ed., War in Darfur and the Search for Peace (Cambridge, MA: Global Equity Initiative, Harvard University, and Justice Africa, 2007), p. 144.

${ }^{864}$ Flint, "Darfur's Armed Movements," p. 147.

${ }^{865}$ Flint, “Darfur’s Armed Movements,” p. 144-145.

${ }^{866}$ Flint, “Darfur's Armed Movements,”p. 145.

${ }^{867}$ Flint, “Darfur's Armed Movements," p. 146.
} 
sponsored groups. The SLA was typically less funded and supported than the JEM. ${ }^{868}$ The JEM also benefited from a more disciplined hierarchical structure. Despite these differences the rebel movements continued to fight on.

How did the violence against Darfurian civilians unfold? Once fighting erupted, the rebels achieved quick success. They killed nearly 700 police officers, destroyed more than 80 police buildings, and had wounded another 500 persons. ${ }^{869}$ The rebels claimed responsibility for these attacks and blamed Khartoum for having marginalized and keeping Darfur in a perpetual underdeveloped state. ${ }^{870}$ The government responded to these vicious attacks by formalizing and arming the Janjaweed, an irregular paramilitary force, to counterattack the rebels. The Janjaweed were the principal perpetrators of violence. However, the national army and air force supported the Janjaweed in bombing Zaghawa and other villages, then allowing the Janjaweed to ride in to town on horseback and slaughter the survivors. ${ }^{871}$ Why did Khartoum rely, in part, on local defense forces and irregular paramilitary units (Janjaweed) to combat the rebels in Darfur? One reason was that al-Bashir and his military commanders could not guarantee where the loyalty of individual units resided - in the national military. Some estimates placed over half of the Sudanese armed forces personnel as coming from Darfur. ${ }^{872}$ This created a dilemma for

\footnotetext{
${ }^{868}$ Flint, “Darfur's Armed Movements,” p. 142.

${ }^{869}$ Mamman Musa Adamu, "An Appraisal of the Crisis in Darfur in Western Sudan and the Prospect for a Lasting Peace," African Research Review Vol. 2, No. 3 (2008), p. 315.

${ }^{870}$ Julie Flint and Alex de Waal, Darfur: A Short History of a Long War (London: Zed Books, 2006).

${ }^{871}$ Adamu, "An Appraisal of the Crisis in Darfur in Western Sudan and the Prospect for a Lasting Peace,” $p$. 316.

${ }^{872}$ Adamu, "An Appraisal of the Crisis in Darfur in Western Sudan and the Prospect for a Lasting Peace,” p. 316.
} 
Khartoum. Obviously the military could not rely on units to murder their own families or neighbors. Therefore, the Janjaweed would be more useful here. The second reason is that, as I have argued in other case studies, the government did not want to be connected to the killing of civilians. In fact, the government consistently and forcefully denied having any connection with the Janjaweed. ${ }^{873}$ This means the government could rely on soldiers to kill Darfurians because they had no personal restrictions and they could deny any association with the campaign to slaughter innocent civilians.

We now understand who the perpetrators were. Let us turn to their tactics for accomplishing mass political violence. Part of the reason the crisis in Darfur reached monumental levels, was due to Khartoum's use of direct and indirect methods of violence. Al-Bashir's government ordered the bombing of villages by the Sudanese Air Force. Then instructed its frontline perpetrators to burn what was left to ashes. These Janjaweed "devils on horseback" also murdered, raped, and systematically destroyed Darfurians livelihoods. ${ }^{874}$ Khartoum's harshness did not end once violence subsided. After each village was bombed, burned, and broken Khartoum denied access to these areas to prevent humanitarian assistance. This act alone sealed the fate of survivors who could not receive adequate medical care or basic necessities to survive. In 2004, government troops and the Janjaweed launched a large scale invasion of northern Darfur

\footnotetext{
${ }^{873}$ BBC News, "World / Africa Analysis: Defining Genocide," February 27, 2007.

${ }^{874}$ James Traub, "Unwilling and Unable: The Failed Response to the Atrocities in Darfur," Occasional Paper Series (New York: Global Centre for the Responsibility to Protect, 2010), p. 2; International Criminal Court, "The Prosecutor v. Omar Hassan Ahmad Al Bashir: Case Information Sheet," Updated April 2018, ICCPIDS-CIS-SUD-02-006/19_Eng.
} 
which forced the rebels to retreat. ${ }^{875}$ Even though an African Union force had been deployed, the killings, mass rape, starvation, and despair of Darfur's population continued. ${ }^{876}$ The Janjaweed used rape as a particularly brutal tactic against women. ${ }^{877}$ Because of the social stigma attached to rape survivors, the Janjaweed raped women en masse so that they died a thousand deaths of humiliation.

When we expose Sudan's use of state-sponsored groups to carry out the $21^{\text {st }}$ century's first genocide, we see six distinct categories of pro-government forces deployed in Darfur. These six go beyond use of the national military and police force. ${ }^{878}$ These forces were: The Peace Force; the Nomad Protection Forces; the Um Bakha irregular forces; the Um Kwak attacker force; the Popular Defense Force; and the Popular Police Force. ${ }^{879}$ All six of the groups worked closely with the Janjaweed and the national military and police forces. Further supporting Darfur as an example of state-sponsored groups mass political violence can be found in the International Criminal Court arrest warrant for al-Bashir where they charged hum as responsible for coordinating the Janjaweed and other groups. ${ }^{880}$ The Janjaweed find their origins back to the 1970 s and 1980s. They formed out of the "local politics of Darfur and the military mobilization of

\footnotetext{
${ }^{875}$ Flint, “Darfur’s Armed Movements," p. 154.

${ }^{876}$ Adamu, “An Appraisal of the Crisis in Darfur in Western Sudan and the Prospect for a Lasting Peace,” 315.

${ }^{877}$ Adamu, “An Appraisal of the Crisis in Darfur in Western Sudan and the Prospect for a Lasting Peace,” p. 316.

${ }^{878}$ Haggar, "The Origins and Organization of the Janjawiid in Darfur,” p. 113.

${ }^{879}$ Haggar, "The Origins and Organization of the Janjawiid in Darfur,” p. 113.

${ }^{880}$ International Criminal Court, "The Prosecutor v. Omar Hassan Ahmad Al Bashir: Case Information Sheet,” Updated April 2018, ICC-PIDS-CIS-SUD-02-006/19_Eng.
} 
Chadian Arabs under Libyan sponsorship." 881 The Janjaweed were "activated" in 2001 and 2003 as a result of certain agreements between Arab tribal leaders. As the war heated up, other Arab and non-Arab groups were outfitted and deployed with the Janjaweed in eastern and southern Darfur. ${ }^{882}$

The term Janjaweed is used to describe armed Arab tribes. However, this term is widely used by outsider groups. The "Janjaweed" prefer to call themselves "horsemen," (Furson) ${ }^{883}$ As Brian Steidle and Gretchen Steidle Wallace wrote, these armed groups were truly "the devil that came on horseback." ${ }^{884}$ The Janjaweed were an ideal statesponsored group. They shared Khartoum's ideology of Arab supremacy and were willing agents of mass political violence.

The Janjaweed began in an abrupt, ad-hoc capacity. However, after several initial years and the evolution of the crisis in Darfur, Janjaweed forces were quickly regularized. They moved from an ad-hoc force into a "semi-regularized or paramilitary" force under direction from Khartoum. ${ }^{885}$ To put it plainly, before the Darfurian rebellion they were localized militias. After the rebellion and their cooptation by al-Bashir's government, the Janjaweed were "official," but unrecognized public forces of the national government. It is vital to note that other Arab and non-Arab militias were formed and used as weapons of war by the state. These competing groups were just as gruesome

\footnotetext{
${ }^{881}$ Haggar, “The Origins and Organization of the Janjawiid in Darfur,” p. 113-114.

${ }^{882}$ Haggar, "The Origins and Organization of the Janjawiid in Darfur," p. 114.

${ }^{883}$ Haggar, “The Origins and Organization of the Janjawiid in Darfur," p. 114.

${ }^{884}$ Brian Steidle and Gretchen Steidle Wallace, The Devil Came on Horseback: Bearing Witness to the Genocide in Darfur (New York: Public Affairs, 2007).

${ }^{885}$ Haggar, "The Origins and Organization of the Janjawiid in Darfur," p. 128.
} 
and effective at killing. ${ }^{886}$ For instance, one such militias were the Murahalin. These militiamen partook in the 1987 massacre of "Dinka people in el Da'ien." 887 Having shown their long time willingness to resort to violence, as a military, the Murahaliin joined the internal conflict in Darfur at the direction of Khartoum. ${ }^{888}$ The government even made overtures to reconcile "intertribal" conflict so that their hand was strengthened vis-à-vis the rebels. ${ }^{889}$ All this demonstrates the secretive nature of the national government and the lengths by which Khartoum went to cover its tracks in the pursuit of mass political violence.

What were the aims of perpetrators in Darfur? There are two broad answers to this question. First, in a narrow view, the government sought to stabilize Darfur and halt further secessionist movements. One way albeit violent, was to employ Arab militias including the Janjaweed to carry out attacks in Darfur as a means to stabilize the rebellion. This goal was criticized by local tribal leaders, especially by those who were not on the frontlines of violence. ${ }^{890}$ These leaders accurately pointed out that by using Janjaweed and other militias in lieu of the professional, regularized troops enabled the violence to spin out of control. As argued at the time, it is difficult for irregular forces to follow internal norms, laws, and moral code once intertribal violence begins. They were simply unable to control themselves from massacring everyone in sight. Moreover, local

\footnotetext{
${ }^{886}$ Haggar, "The Origins and Organization of the Janjawiid in Darfur,” p. 128.

${ }^{887}$ Haggar, “The Origins and Organization of the Janjawiid in Darfur,” p. 129.

${ }^{888}$ Haggar, "The Origins and Organization of the Janjawiid in Darfur,” p. 128.

${ }^{889}$ Haggar, "The Origins and Organization of the Janjawiid in Darfur,” p. 128.

${ }^{890}$ Haggar, "The Origins and Organization of the Janjawiid in Darfur," p. 115.
} 
leaders correctly predicted that the use of the Janjaweed would hinder political reconciliation. ${ }^{891}$ The second and overarching aim of the perpetrators was to fundamentally alter the demography of the region. ${ }^{892}$ Through a secretive public policy, Khartoum could alter the demography composition of Darfur, thereby maintain its dominance over the province. This was a maximum goal for the use of mass political violence.

One common thread in this dissertation is that perpetrators of mass political violence may engage in violent acts for a specific reason, a multitude of reasons, or for no reason at all. The extant literature in the Darfur genocide has debated at least five main causes for the crisis. Because I view large-scale violence as instrumental, the overarching reasons are not my first concern in explaining violence. As such, I will briefly cover the debate over causes here. The first explanation blames ethnic and religious differences for fomenting the rebellion and subsequent government crackdown on the civilian population. The news media largely portrayed the crisis as a "tribal" conflict between black African villagers in Darfur and Arab militias. ${ }^{893}$ This first, popular wave of discourse has been questioned by scholars like Ateem Selso and Alex de Waal, among others who demonstrate in their research that "there is little or no racial difference between the language groups..." as a result of intergroup marriage over time. ${ }^{894}$

\footnotetext{
${ }^{891}$ Haggar, "The Origins and Organization of the Janjawiid in Darfur," p. 115.

${ }^{892}$ Haggar, "The Origins and Organization of the Janjawiid in Darfur," p. 114.

${ }^{893}$ Adamu, "An Appraisal of the Crisis in Darfur in Western Sudan and the Prospect for a Lasting Peace," p. 317.

${ }^{894}$ Adamu, "An Appraisal of the Crisis in Darfur in Western Sudan and the Prospect for a Lasting Peace," p. 317.
} 
Nevertheless when mass political violence erupts between two "different" groups this is often the first explanation offered.

The second explanation offered is that Khartoum had a "single minded" directive to subjugate, marginalize, and ultimately eradicate the black African groups in Darfur and drive or kill them from Sudan. ${ }^{895}$ Eric Reeves argues that the government of Sudan directed all Janjaweed and militias to "change the demography of the area and make it void of African tribes by killing people, burning their villages and forms, terrorizing them and confiscating their property and forcing them out of the region." ${ }^{\not 96}$ Reeves concluded this from documents that were seized from Janjaweed persons. Third, more similar to the ethnic and racial explanation, is authors who contend that the tribal/racial conflict was not rooted in their identities but actually the competition over scarce natural resources. ${ }^{897}$ In this case the violence stems from traditional competitions over land. The fourth explanation, and are in which I am most inclined to associate with, places the genesis of violence in Darfur as a power struggle between a province and the capital. ${ }^{898}$ Darfur had been neglected for decades, even during colonialism the region had been marginalized by its governors. Authors here bring the state back in to discuss the center-periphery battle between Khartoum and Darfur that was fundamentally rooted in a battle over regional autonomy and independence. Scholars in this stream of research argue all excesses in war

\footnotetext{
895 Eric Reeves, "Stopping Genocide in Darfur: What Must Be Done", May 17, 2004. URL: http:sudanrevees.org.

${ }^{896}$ Adamu, “An Appraisal of the Crisis in Darfur in Western Sudan and the Prospect for a Lasting Peace,” 319.

${ }^{897}$ Haggar, “The Origins and Organization of the Janjawiid in Darfur,” p. 138.

${ }^{898}$ Bassil, The Post-Colonial State and Civil War in Sudan, p. 15.
} 
originated from this challenge to state authority. Finally, there is scholarship that addresses the international dimension in the conflict. For example, where did perpetrators obtain their weapons? China was accused of providing some weapons to Sudan, in exchange for oil contracts. ${ }^{899}$ An oil for guns program, if you will. That said, China's interest in the Sudanese government's right to absolute sovereignty was another reason for their involvement. ${ }^{900}$ China has been a staunch defender of absolute sovereignty and therefore opposed to international intervention in Darfur. ${ }^{901}$ Western powers, like the United States' Central Intelligence Agency were also supplying arms, munitions, and money to Darfur's rebels, as they did in South Sudan. ${ }^{902}$ The U.S. engaged in this type of covert action because Sudan's Islamic government was “deemed insufficiently proAmerican and too Islamic." 903 Another international dimension was the presence of alQaeda in Darfur. Al-Qaeda had chosen Afghanistan as a training ground because of its secluded nature from global politics. Al-Qaeda was interested in Darfur because of the region's lax borders and historically neglected nature in domestic, regional, and global politics. ${ }^{904}$ Members of the JEM rebel group also received limited training from al-Qaeda

\footnotetext{
${ }^{899}$ Adamu, "An Appraisal of the Crisis in Darfur in Western Sudan and the Prospect for a Lasting Peace," p. 323.

900 Traub, "Unwilling and Unable," p. 11.

901 Traub, "Unwilling and Unable," p. 11.

902 Adamu, “An Appraisal of the Crisis in Darfur in Western Sudan and the Prospect for a Lasting Peace," p. 324.

${ }^{903}$ Adamu, "An Appraisal of the Crisis in Darfur in Western Sudan and the Prospect for a Lasting Peace," p. 324.

${ }^{904}$ Adamu, "An Appraisal of the Crisis in Darfur in Western Sudan and the Prospect for a Lasting Peace," p.
} 324. 
instructors on logistics and guerrilla and urban warfare. ${ }^{905}$ Therefore, China and the U.S. used Darfur as a low-level proxy conflict, but for entirely different reasons.

We will never know the exact number of people who died in the Darfur region. ${ }^{906}$ As we have seen in other cases, estimating an exact mortality rate is especially challenging. This is partly due to Darfur's inaccessibility to outsiders, but estimates are also challenged by counting the number of victims killed by direct and indirect means of violence. How many Darfurians died from their inability to access clean watering holes that were guarded by Janjaweed horsemen? How many fled as refugees but fell victim to starvation or maladministration in neighboring countries? The estimates below may only scratch the surface of the total body count.

There is no doubt that the conflict in Darfur led to an enormous loss of life, property, culture, and dignity for locals. In a speech to the UN General Assembly on September 21, 2004, US President George W. Bush said "the world is witnessing terrible suffering and horrible crimes in the Darfur region of Sudan, crimes my government has concluded are genocide. ${ }^{907}$ Unfortunately, by early 2005 the Bush Administration had backed off this definitive claim. ${ }^{908}$ For a superb discussion of "the politics of civilian casualty counts" see Taylor Seybolt, Jay Aronson, and Baruch Fischhoff's Counting Civilian Casualties book. The bulk of killing occurred between 2003 and 2005. The US

\footnotetext{
${ }^{905}$ Adamu, "An Appraisal of the Crisis in Darfur in Western Sudan and the Prospect for a Lasting Peace," p. 324.

${ }^{906}$ Debarati Guha-Sapir and Olivier Degomme, "Counting the Deaths in Darfur: Estimating mortality from multiple survey data," Households in Conflict Network, The Institute of Development Studies (Falmer, England: University of Sussex, 2006), p. 1.

907 “Transcript of Bush's UN Address," CNN.com, September 21, 2004, Accessed on August 21, 2018. URL: www.cnn.com.2004/US/09/21bush.un.transcript/index.html.

${ }^{908}$ Seybolt et al., Counting Civilian Casualties, p. 43.
} 
Department of State estimated the number of death to be between 98,000 and 181,000 dead from March 2003 to January 2005..$^{909}$ The UN has referenced the Coalition for International Justice who contend almost 400,000 have died. ${ }^{910}$ Eric Reeves, as cited above, argues that the true number could be upwards of 500,000, while the WHO counted 50,000 in September 2004. There is a plethora of estimates that fall within this range. What I can definitively conclude is that the thresholds established in this dissertation were not only met but far exceeded. I simply cannot conclude by how much the body count threshold was surpassed.

\section{A Dynamic Structural Approach to Non-State Perpetrators}

Genocide Studies is logically a reactive field. This interdisciplinary research enterprise has developed in response to some of history's most severe atrocities. Eric Weitz argues that the $20^{\text {th }}$ century should be named "a century of genocide." 911 Weitz, in part, labels the $20^{\text {th }}$ century this way because it was host to many large-scale atrocities. These mass political violence episodes were most often directed by states or state-society coalitions. Now that we live comfortably in a new century, are that is wirelessly connected, perpetrators of mass political violence have evolved. The final category of perpetrator I discuss is non-state actors. Historically, these groups have been under

\footnotetext{
${ }^{909}$ Government Accountability Office, "Darfur Crisis: Death Estimates Demonstrate Severity of Crisis, but Their Accuracy and Credibility Could Be Enhanced" (Washington, DC: Government Accountability Office, 2006), p. 1.

${ }^{910}$ Coalition for International Justice, "New Analysis Claims Darfur Deaths Near 400,000: Experts Estimates 500 People A Day Are Dying,” 2005.

${ }^{911}$ Eric D. Weitz, A Century of Genocide: Utopias of Race and Nation (Princeton: Princeton University Press, 2003).
} 
theorized vis-à-vis their ability to commit genocide and mass political violence. This state-centric bias is demonstrated time and again. In fact, when defining the conceptual boundaries of what is and is not genocide, scholars like Vahakn Dadrian, Isidor Wallimann and Michael Dobkowski, Tony Barta, Barbara Harff, Ted Robert Gurr, Frank Chalk, Kurt Jonassohn, Robert Melson, Irving Louis Horowitz, Levon Chorbajian, and Manus Midlarsky specifically defined genocide as an exclusively state-directed act. It is true that three of four perpetrator categories possess some form of state involvement in mass political violence. However, non-state actors, who operate independently of states also have an increasing ability to wage this type of human destruction.

How are non-state actors conceptually and empirically different from statesponsored groups? Both are considered non-state armed groups. From an outsider's perspective to a conflict, each group may seem similar or act in analogous ways. Therefore, what makes non-actors different? The crucial distinction lies in the fact that no government is pulling the strings behind the scene. It may appear that state-sponsored groups are independent of the government, but in actuality the government is coordinating their supplies, issuing orders, or actively allowing the group to roam their territory without fear of accountability. For non-state actors there is no state-group connection. The only possible connection would be that a particular state government was so weak, fragile, or collapsed that its inability to govern gave rise to the sociopolitical conditions that forms a breeding ground for non-state actors. The second characteristics is that violence is independent with little sustained killing capacity. On the contrary states can and do wage war on civilian populations for years and decades. Nonstate actors are most likely to possess limited means and ability to kill large groups of 
people for months and years, and not decades. The time horizon is considerably shorter for these group perpetrators.

There are specific socio-political conditions that enable non-state perpetrators to develop. The regime's power is low too moderate: this practically means the regime lacks political power and influence, control is often limited to the capital city or essential military installations. That said, the regime lacks a monopoly on the use of force within its sovereign lands. Similarly, state capacity is weak, so much so that the state cannot effectively coordinate, mobilize or control its population. Finally, the social appetite for violence is limited and there may be isolated pockets of support for non-state actors to emerge.

Non-state actors have existed as a perpetrator category long before modern states were formed. These groups quickly fell out of favor as states replaced kingdoms and monarchies as the most powerful unit. Throughout the $20^{\text {th }}$ century, at least until the end of the Cold War, states were the far majority in terms of number of mass political violence perpetrators. However, as more states confront internal conflicts like democratic challenge, social movements, or rebellion, non-state actors once again have emerged as a viable alternative for enacting mass violence. Since Genocide Studies only emerged during the height of modern states' power, it has almost entirely focused on cases where the perpetrators were members of a state. This is a bias we must change. As the world changes, so must our theoretical understanding. It is for this reason that non-state actors must be readily included into our intellectual canon. What follows is three examples of mon-state perpetrators carrying out mass political violence. 


\section{Brief Case Studies: Non-State Actors}

\section{$\underline{\text { Pre-Communist China and Mao Zedong }}$}

Mao Zedong once wrote, “A revolution is not a dinner party, or writing an essay, or painting a picture, or doing embroidery; it cannot be so refined, so leisurely and gentle, so temperate, kind, courteous, restrained, and magnanimous. A revolution is an insurrection, an act of violence by which one class overthrows the power of another."912 Mao Zedong is undoubtedly the most influential Chinese leader of the last century. He was a student turned revolutionary, turned military genius, autocrat and mass murderer. ${ }^{913}$ Under Mao's leadership - before and after the civil war - China "was transformed from a weak, disunited country to a power on the world stage." 914 When we reflect on Mao's accomplishments, we often think of his tenure as China's Communist Party Chairman and not of his rebel years. This section explores the devastation in Mao's wake that led to his eventual totalitarian control over mainland China. Mao's strategy was a “socialist transformation through the process of political mobilization," similar, in part, to Stalin's Soviet Union and Pol Pot's Cambodia. ${ }^{915}$ That transformation began in the "wilderness" when the Chinese Communist Party (CCP) was driven into near exile in the 1920s. ${ }^{916}$ There is little data on this period. Historians have been able to piece together a record

\footnotetext{
${ }^{912}$ Delia Davin, Mao: A Very Short Introduction (Oxford: Oxford University Press, 2013), p. 21.

${ }^{913}$ Davin, Mao, p. 1.

${ }^{914}$ Davin, Mao, p. 1.

915 Charles P. Cell, Revolution at Work: Mobilization Campaigns in China (New York: Academic Press, 1977), p. 1.

${ }^{916}$ Edgar Snow, Random Notes on Red China: 1936-1945 (Cambridge, MA: East Asian Research Center, Harvard University Press, 1968), p. v.
} 
based on "reports of observers, particularly of journalists who collected information from Communist leaders themselves when opportunity was particularly favorable in the midthirties." $" 917$

Non-state actors thrive in circumstances of social and political instability. There is no better way to describe China in the period of Mao Zedong's emergence. The Chinese government was "corrupt" and "inept.",918 Immediately preceding Japan's invasion of China, the government remained "a patchwork of regional powers." 919 There was very little popular support for the "national government." Many locals were still affiliated with regional warlords or other factions. The CCP defined China during this period as "a weak semi-colonial and semi-feudal country." ${ }^{, 920}$ The divide between urban residents and rural people became even more transparent as the imperial democracy failed in its fiscal responsibilities. ${ }^{921}$ Thus rural villages were "left on their own to a great extent."922 Chinese cities posed everything their rural counterparts lacked. They were developing rapidly, particularly from western influences. ${ }^{923}$ This stark divide in social politics

\footnotetext{
${ }^{917}$ Snow, Random Notes on Red China, p. v.

918 Jerome Ch'en eds., Mao (Englewood Cliffs, NJ: Prentice-Hall, Inc, 1969), p. 9

${ }^{919}$ Henry G. Schwarz, Liu Shao-Ch'I and "People's War": A Report on the Creation of Base Areas in 1938 (New York: Paragon Book Gallery, Ltd, 1969), p. 3-4

${ }^{920}$ Lin Piao, Long Live the Victory of People's War! (Peking: Foreign Languages Press, 1965), p. 1; Mao Tse-Tung, On Protracted War (Peking: Foreign Languages Press, 1967), p. 15.

${ }^{921}$ Peter Zarrow, China in War and Revolution, 1895-1949 (London and New York: Routledge, 2005), p. 101.

${ }^{922}$ Zarrow, China in War and Revolution, p. 101.

${ }^{923}$ Zarrow, China in War and Revolution, p. 112.
} 
coupled with a weak national government provided Mao with an opportunity to break

out.

In chapter three I argue that non-state actors typically possess little to no support from local populations. In China's case, this was originally a valid claim, but as the CCP grew into a national social movement, its support could no longer be described as "little." In this sense the CCP's rise as a non-state perpetrator deviates slightly from the ideal type. That said, when assessing a group's support, it is helpful to use both absolute and percentage numbers. When the CCP held its first Soviet congress in 1931, they claimed to represent eight to 10 million people. ${ }^{924}$ This is a large number of "supporters," or at least Chinese they claim to represent. Population data is scarce for this time period. However, in 1932-1933 China's population was about 429.5 million. ${ }^{925}$ Assuming both of these numbers are accurate - and that is a substantial assumption for the former - the CCP could claim about 2.3 percent societal support. In this respect their societal support confirms to the typology in chapter three. China is both unique and ordinary in this respect. ${ }^{926}$

\footnotetext{
924 Edgar Snow, Random Notes on Red China: 1936-1945 (Cambridge, MA: East Asian Research Center, Harvard University Press, 1968), p. 18-19.

${ }^{925}$ Office of Population Research, "Current Estimates of the Size and Distribution of China's Population," Population Index Vol. 14, No. 1 (January 1948), p. 6.

${ }^{926}$ There has been much written about the extent to which Chinese actually supported the CCP or passively supported them to combat the Japanese invasion of northern China. In this sense the CCP's support was comprised of ideologies but also other Chinese who simply wanted to fight back against this external terror. To use a phrase, "all politics is local," applies here. One CCP official said "starting up the mass movement is not a simple matter. We should decide the policy of our mass movement on the basis of local circumstances..." The debates on the role of China's peasantry are to detailed for a discussion here. One view is that China's peasantry was initially passive, indifferent, and after the Japanese invasion wanting to be utilized in this national struggle. Others like Frederick T.C. Yo and Stewart Fraser contend that the population had to undergo substantial re-indoctrination and re-education to support the CCP. Either way the CCP did motivate China's population for wholesale war. See Davin, Mao, p. 36; Schwarz, Liu Shao-Ch'I
} 
Mao grew up in a period of "intense nationalism against foreign interests in China." ${ }^{927}$ In 1911 the Chinese dynasty was overthrown by a revolution. ${ }^{928}$ However, the new republic that filled the void continued the tradition of political maladministration. After the revolution and founding of the new republic, "no single national government achieved control over the whole of China." ${ }^{929}$ In the next decade and a half china had seen "at least four different constitutions, and all of them became dead letters as soon as they were promulgated." ${ }^{930}$ Mao rose from an isolated peasant with grand goals to one that could unite disenfranchised youth against the ineffective "national" government.

By the summer of 1921 delegates from far and wide came together for the First Congress of the Chinese Communist Party. ${ }^{931}$ Moscow had dispatched persons to attend and help steer the movement in this early stage. Right from the beginning the Chinese Communists resented Moscow's attempt to influence China's Communist movement. This tension helps demonstrate that the $\mathrm{CCP}$ was a non-state actor and not a statesponsored group operating on behalf of the Soviet Union. In June 1923 the CCP began its first United Front with the Kuomintang (National Party). ${ }^{932}$ This détente did not last long. The infamous Chiang Kai-Shek led a coup against the CCP three years later. The next

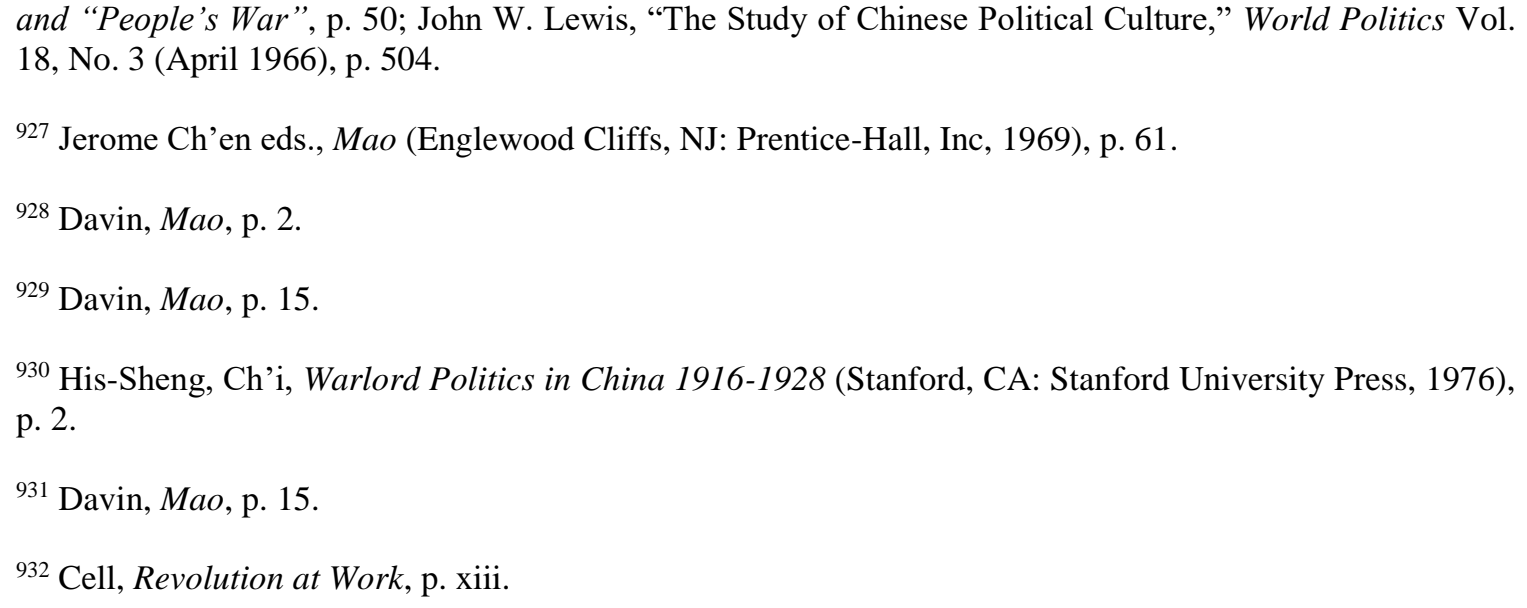


decade is characterized by Kuomintang forces solidifying control over China's urban centers and the CCP moving to border regions to establish a base of operations. ${ }^{933}$ As the Japanese invasion of northern China intensified and World War II escalated, the CCP and Nationalist forces formed a second United Front in December 1936. ${ }^{934}$ It is here that the Communist rebels under Mao's leadership began the process of mass mobilization. ${ }^{935}$ The second alliance allowed the $\mathrm{CCP}$ to rebuild its forces, organize a stronger command and control system, and survive until the end of the war. After Japan's unconditional surrender in 1945, Mao plotted to overthrow the United Front. Within a year's time, allout civil war ensued between the CCP and Kuomintang. However, this time the advantage lay with the Communists.

Mao's success in the late 1940s against the Kuomintang can be traced back to his time in the 1920s where he systematically established rural bases. After facing near defeat, Mao created his new strategies for winning wars and subduing populations. The prime lesson learned was that "political power is obtained from the barrel of a gun." ${ }^{936}$ By the time World War II ended, the CCP was no longer a small non-state actor. It was a force consisting of about two million men fully capable of fighting any known army in the world. ${ }^{937}$

\footnotetext{
${ }^{933}$ Cell, Revolution at Work, p. xiii.

${ }^{934}$ Cell, Revolution at Work, p. xiv.

${ }^{935}$ Cell, Revolution at Work, p. xiv.

${ }^{936}$ Davin, Mao, p. 23.

${ }^{937}$ Peter Carter, Mao (London: Oxford University Press, 1976), p. 116.
} 
Unlike the Islamic State or the Lord's Resistance Army today, Mao's CCP conducted surveys - at least in the beginning - of social and economic life of villagers. ${ }^{938}$ He used this information to form a national plan which would eventually be forced upon the same villagers he once sought guidance from. Mao gave the peasantry a voice. Once China's peasantry and youth were secured in the fight for Communism, he broadened his goals. One of the tactics that may not be solely unique to non-state actors but at minimum intensified is their recruitment of youth. All three non-state actors in this section rely on youth support - coerced or voluntary. By 1934, the Communist youth force reached $100,000 .{ }^{939}$ In the same year about 40 percent of the CCP's army writ large was comprised of men under 23 years of age. ${ }^{940}$ The motto of the CCP's youth brigades was, "You do the work at the front; we'll do the work in the rear."941 That said, Mao's strategies went far beyond coopting China's youth.

How did Mao's leadership and strategies cause so much devastation? First, Mao’s doctrine was to secure and live off the rural lands. Thus he would order the full encirclement of major metropolitan areas and then launch attacks on these urban areas. This policy of encirclement and subsequent attack on cities led to widespread civilian casualties. Particularly when the CCP marched into town. In Mao's own words:

To achieve success, the Chinese troops must conduct their warfare with a high degree of mobility on extensive battlefields, making swift advances, and withdrawals, swift concentrations and dispersals. This means large-

\footnotetext{
${ }^{938}$ Davin, Mao, p. 27.

939 Edgar Snow, Random Notes on Red China: 1936-1945 (Cambridge, MA: East Asian Research Center, Harvard University Press, 1968), p. 52.

${ }^{940}$ Snow, Random Notes on Red China, p. 52.

${ }^{941}$ Snow, Random Notes on Red China, p. 55.
} 
scale mobile warfare, and not positional warfare depending exclusively on defense works with deep trenches, high fortresses and successive rows of defensive positions. It does not mean the abandonment of all the vital strategic points, which should be defended by positional warfare as long as profitable. But the pivotal strategy must be mobile warfare. ${ }^{942}$

Mao would go on to say that the "key to victory... lies in developing... a war of total resistance by the whole nation. Only through such a war of total resistance can final victory be won." 943 If any Chinese or foreign national did not endorse this strategy, then they fell victim to its brutality. Mao said to Lin Piao, another CCP official, "Be firmly determined to fight a battle of annihilation on a scale larger than you have ever fought before."944 Through his words, it is self-evident that all of Chinese society had to choose a side in this total war. Failure to embrace Communism meant certain death for many. And, even among those converts, loyalty to the party - and Mao - was prized above all else.

To highlight the power of Mao's leadership in converting Chinese to his side, we can simply review the CCP's strength and organization. In 1921 there were 57 party members. ${ }^{945}$ By 1925 this number increased to 950 party members. ${ }^{946}$ After a major labor incident and subsequent movement of May $30^{\text {th }}$, the CCP saw a massive increase in recruits. Within two years there were about 68,000 members and by 1933 its ranks

\footnotetext{
${ }^{942}$ Mao Tse-Tung, On Protracted War (Peking: Foreign Languages Press, 1967), p. 9.

943 Tse-Tung, On Protracted War, p. 12.

944 Tse-Tung, On Protracted War, p. 12.

${ }^{945}$ Franz Schurmann, Ideology and Organization in Communist China, Second Edition, Enlarged (Berkeley and Los Angeles, 1968), p. 129.

946 Schurmann, Ideology and Organization in Communist China, p. 129.
} 
swelled to about 300,000 persons ${ }^{947}$ Every year since, CCP party members steadily climbed and eventually arrived at 1.2 million in 1945, 2.8 million in 1947, and by the end of the Chinese Civil War possessed over 3 million. ${ }^{948}$ This evolution shows that one reason Mao's CCP was able to kill and destroy much of China's urban centers lay in his ability to convince Chinese to join his cause. Of the three non-state actors in this section Mao's insurgency is the only one that transitioned from a ragtag insurgency to a state force - and eventually would become state perpetrators of mass political violence.

Finally, connecting Mao's ideology and strategy to mass civilian casualties. Mao once said, "After our armed enemies have been crushed, there will still be our unarmed enemies, who will try to fight us to the death. We must never underestimate their strength. Unless we think of the problem in precisely those terms, we will commit the gravest of errors. ${ }^{" 449}$ Mao turned China from a patchwork of semi-autonomous regions into a totalitarian state within several decades. If it was not for his ill-will towards those who differed slightly, this transition could have been hailed as a remarkable achievement. Mao ruled post-civil war China with such power that he was known as the "Red Emperor. ${ }^{950}$ We can see the beginnings of his totalitarian tendencies during China's civil war periods. Like all too many conflicts, the true number of deaths attributed to the Chinese civil war will never be known. ${ }^{951}$ The CCP killed millions of Chinese, but so too

\footnotetext{
${ }^{947}$ Schurmann, Ideology and Organization in Communist China, p. 129.

${ }^{948}$ Schurmann, Ideology and Organization in Communist China, p. 129.

${ }^{949}$ Courtois et al., Black Book, p. 463.

${ }^{950}$ Courtois et al., Black Book, p. 465-466.

${ }^{951}$ Michael Lynch, The Chinese Civil War 1945-49 (Oxford: Osprey Publishing Ltd, 2010), p. 91.
} 
did the Kuomintang, and warlord kingdoms. ${ }^{952}$ Just within the civil war period of 194649, six million civilians and soldiers lost their lives. ${ }^{953}$ If we simply look at the CCP's advance on Szechuan, an area with about one million inhabitants. When the Red Army left, "the population was reduced by half." 954 Though it will never fully by understood, the true devastation enacted on China's population will go down in history as one of the bloodiest conflicts vis-à-vis civilian in known human history.

\section{The Lord's Resistance Army}

Before there was the Islamic State, there was the Lord's Resistance Army (LRA) in central and east Africa. The LRA began in 1987 as an off shoot of the Holy Spirit Movement. ${ }^{955}$ The LRA, led by Joseph Kony, is a criminal, terrorist and non-state perpetrator of mass political violence. Most of the deaths attributed to Kony's fighters have come from indirect means and second order effects of his violence. The original goal of the LRA was "allegedly [to carry out] ... an insurgency against the government of Uganda and the Ugandan army..." ${ }^{956}$ However, the consequences of this so-called insurgency fell hardest on the Acholi people. ${ }^{957}$ The LRA has "brutalized" civilians

\footnotetext{
952 Snow, Random Notes on Red China, p. 87.

${ }^{953}$ Lynch, The Chinese Civil War 1945-49, p. 7, 91.

${ }^{954}$ Snow, Random Notes on Red China, p. 87.

955 "Profile: The Lord's Resistance Army" Al Jazeera (May 6, 2014). URL: https://www.aljazeera.com/news/africa/2011/10/2011101418364196576.html.

${ }^{956}$ International Criminal Court, "The Prosecutor v. Joseph Kony and Vincent Otti: Case Information Sheet" Updated April 2018, ICC-PIDS-CIS-UGA-001-006/18_Eng, p. 2.

${ }^{957}$ Frank Van Acker, "Uganda and the Lord's Resistance Army: The New Order No one Ordered" African Affairs Vol. 103. No. 412, (2004), pp. 335.
} 
through "acts including murder, abduction, sexual enslavement, mutilation, as well as mass burnings of houses and looting of camp settlements and that abducted civilians, including... [have been used as] fighters, porters, and sex slaves." 958

In the years since its founding, the LRA's leader Joseph Kony has faced at least 12 counts of crimes against humanity, and 21 counts of war crimes. ${ }^{959}$ Kony has claimed in the past to be "possessed by multiple spirits." $" 960$ Perhaps as a way of deflecting guilt over his bloodthirsty acts. According to some reports, the LRS has abducted over 67,000 youth, among which about 30,000 were and are children. ${ }^{961}$ Nearly 1.5 million people have been internally displaced. ${ }^{962}$ The LRA became the first non-state perpetrator to be referred to the International Criminal Court by a head of state - Ugandan President Yoweri Museveni. ${ }^{963}$ At the core of this conflict resides the fact that "consecutive Ugandan [and neighboring Congo, South Sudan, and the Central African Republic governments have failed] to construct and consolidate a modern state that legitimizes and

\footnotetext{
958 Van Acker, "Uganda and the Lord's Resistance Army,” p. 2.

959 Van Acker, "Uganda and the Lord's Resistance Army,” p. 1.

960 Anthony Vinci, “The Strategic Use of Fear by the Lord's Resistance Army” Small Wars and Insurgencies Vol. 16, No. 3 (2005), pp. 360.

961 The Enough Project, "Lord's Resistance Army" Accessed: May 24, 2018. URL: https://enoughproject.org/conflicts/lra).

962 Tim Allen and Koen Vlassenroot eds., The Lord's Resistance Army: Myth and Reality (London and New York: Zed Books, 2010), p. ix.

963 "International Criminal Court Investigations Uganda,” Global Policy Forum, Accessed: June 9, 2018. URL: https://www.globalpolicy.org/international-justice/the-international-criminal-court/iccinvestigations/uganda.html.
} 
promotes a collective aspirations, and to wield the magnitudes and levels of power a modern state conveys." 964

Even though the Ugandan state could not adequately control its northern territory the LRA moved its bases around and between northern Uganda, the CAR, South Sudan, and Congo-Kinshasa. ${ }^{965}$ The fact that all these countries could not control their territory led to the rise and preservation of the LRA today.

The LRA has always struggled to garner popular support in any of its occupied territories. The "rampant atrocities undermine[d] the credibility of the LRA as a popular political protest." $" 966$ This is squarely in line with the prediction of low societal support for non-state perpetrators of mass political violence. Some have argued that Kony's tactics rise to "religious terrorism," and not political terrorism because of his belief to rule Uganda in accordance with the Christian Ten Commandments and thus "purify" society. ${ }^{967}$

Kony's LRA used the idea of "strategic fear" to paralyze Ugandan society and hold it hostage to his radical demands. ${ }^{968}$ Even though the LRA has received resources from the Sudanese government, they are not beholden to any group or nation. ${ }^{969}$ Sudan initially sought the LRA to open up a second front in their war against the SPLM/A in

\footnotetext{
964 Van Acker, “Uganda and the Lord's Resistance Army,” p. 336.

965 The Enough Project, "Lord's Resistance Army" Accessed: May 24, 2018. URL: https://enoughproject.org/conflicts/lra).

966 Van Acker, “Uganda and the Lord's Resistance Army,” p. 336.

${ }^{967}$ Van Acker, “Uganda and the Lord's Resistance Army,” p. 349.

968 Vinci, "The Strategic Use of Fear by the Lord's Resistance Army,” p. 361.

969 Van Acker, “Uganda and the Lord's Resistance Army,” p. 337.
} 
southern Sudan. LRA “soldiers” used hit-and-run tactics. One solider said, "we killed people so that they would fear us." "970 These tactics coupled with the use of "strategic fear," meaning killing people to fear the LRA, became a "force multiplier." 971 This is in part how a small ragtag group of gangsters consisting of no more than 3,000 at any given time could hold off a professional army of about 40,000 to 60,000 strong, engage in simultaneous battle with the SPLA, and all the "while effectively controlling millions of civilians in the north... an area the size of Belgium." 972

Why count the LRA as a non-state perpetrator of mass political violence? One justification is that their violence and tactics were used as "collective punishment" for the civilian population. ${ }^{973}$ Since the late 1980 s Kony's insurgency has forcibly “abducted tens of thousands of children and adults to serve as porters and soldiers." 974 Some of these abductees who were as young as seven years old were coerced into mutilating and murdering civilians and in some cases members of their own families and villages. ${ }^{975}$ Despite president Museveni's proclamation that 2002 "would be a year of peace for all

\footnotetext{
${ }^{970}$ Vinci, "The Strategic Use of Fear by the Lord's Resistance Army," p. 360.

${ }^{971}$ Vinci, “The Strategic Use of Fear by the Lord's Resistance Army,” p. 361.

972 The LRA had between 500 and 1,000 "hardcore fighters," and up to 2,000 additional fighters of carrying degrees of loyalty. Vinci, “The Strategic Use of Fear by the Lord's Resistance Army,” p. 361; 368.

${ }^{973}$ Allen and Vlassenroot, The Lord's Resistance Army, p. 38.

974 Phoung Pham, Patrick Vinck, and Eric Stover, “Abducted: The Lord's Resistance Army and Force Conscription in Northern Uganda" Berkeley-Tulane Initiative on Vulnerable Populations (Human Rights Center, University of California, Berkeley, Payson Center for International Development, Tulane University, June 2007), p. 1.

${ }^{975}$ Pham, et al., "Abducted," p. 1.
} 
Ugandans," the LRA attacks increased. ${ }^{976}$ By 2003 the LRA incursions had become so bad that the number of people residing in displacement camps was about $800,000 .{ }^{977}$ Human Rights Watch placed their estimate at between 800,000 and 1.2 million displaced persons. ${ }^{978}$ The terror was such that people were called "night commuters." They would flee the area at night for safety and return to their lands during daylight hours.

As I argue in chapter three, the weakness of a regime coupled with low state capacity and limited to no societal support will enable non-state actors to emerge if they wish to do. The post-colonial Ugandan state was "rooted in the militarization of society."979 However, these recruits were often "low-skilled," "ill-trained," and of "poor discipline" to project power throughout the land. The weakness of this force allowed the LRA to take advantage of a political opening and maintain its campaign of mass political violence for decades. They have garnered additional resources from outside the territory and in some areas coerced or accepted local support. All told, despite Museveni's claim that the LRA were puppets of the Sudanese state. I argue that it was Uganda's own failures to govern that, in part, led to the LRA's rise and persistence.

It is clear through the actions of LRA members and its leadership that they conceptually fit within the non-state perpetrator category. It is difficult to estimate the total and annual death tolls enacted on the region. That said, according to the UN, the

\footnotetext{
${ }^{976}$ Morten Bøås and Kevin C. Dunn, eds., African Guerrillas: Raging Against the Machine (Boulder, CO: Lynne Rienner Publishers, 2007), p. 131.

${ }^{977}$ Bøås and Dunn, African Guerrillas, p. 131.

${ }^{978}$ Human Rights Watch (HRW), Abducted and Abused: Renewed Conflict in Northern Uganda, Report Vol. 15, No. 12 (A), July 2003, available online at http://www.hrw.org/reports/2003/uganda0703 (visited 5 February 2004), p. 37.

${ }^{979}$ Van Acker, “Uganda and the Lord's Resistance Army,” p. 339.
} 
LRA has killed through direct and indirect means more than 100,000 people in the central and east Africa region. ${ }^{980}$ Death's attributable to direct violence is likely in the low single to tens of thousands. ${ }^{981}$ I stress likely. However, we can never be certain. Indirect violence has claimed far more lives. According to

Adults surveyed in camps... over 50 percent had been abducted at some point during the war, nearly 40 percent had their own children abducted, over two-thirds had witnessed a child abducted, nearly half had witnessed a family member being killed, over half had been threatened with death, and nearly 20 percent had been physically mutilated, maimed or injured. ${ }^{982}$

Despite these gruesome accounting, the overall violence faced by persons in camps were much higher. The World Health Organization and the Ugandan Ministry of Health said that in 2005 , there were an estimated 1,000 excess deaths per week. ${ }^{983}$ Though not directly killed by Kony's henchmen these men, women, children, brothers, sisters, and fellow human beings are dead because of the LRA's insidious campaign of terror. Therefore, they bear responsibility for this mass political violence.

\footnotetext{
980 "Kony's LRA has killed more than 100,000: UN" The Denver Post (Denver, Colorado) May 20, 2013. URL: https://www.denverpost.com/2013/05/20/konys-lra-has-killed-more-than-100000-un/.

${ }^{981}$ Joe Bavier, "Victims of Uganda's Lord's Resistance Army" The Telegraph, February 18, 2011. URL: https://www.telegraph.co.uk/news/worldnews/africaandindianocean/uganda/8331004/Victims-of-UgandasLords-Resistance-Army.html.

982 Ronald R. Atkinson, "From Uganda to the Congo and Beyond: Pursuing the Lord's Resistance Army" International Peace Institute (December 2009), p. 8.

${ }^{983}$ Atkinson, "From Uganda to the Congo and Beyond," p. 9.
} 


\section{The Islamic State}

David Wasserstein says it best, "We know both too much and too little about the Islamic State." 984 Similar to the LRA, the Islamic State uses strategic fear and strategic violence to conquer land, subdue populations, and instill all-out fear into large groups of people in Iraq, Syria, and beyond. The Islamic State has become the poster child for nonstate perpetrators in this age. They are a truly "deadly and adaptive foe... [That] seemed to come out of nowhere in June 2014, when it conquered Mosul, Iraq's second-largest city." 985 Previously named the Islamic State of Iraq and Syria (ISIS), the group advanced into Syrian territory in the second half of $2011 .{ }^{986}$ After consolidating its strategy, building on small and mid-level gains, the terror group expanded in to Iraq in 2014. Howard Shatz and Erin-Elizabeth Johnson write, “...instead of limiting its savagery, [ISIS] doubled down." "987 The Islamic State has not reached anywhere close to causing turmoil and destruction as Mao's forces have, but it is not because of a lack for trying.

The terror group's origins can be traced to the early 1990s. In 2004 one of the group's founders had been working with al-Qaeda in Iraq. ${ }^{988}$ There had been several successful counterinsurgency operations led against this and other terror groups in the 2000s. In 2010, the group's most well-known leader, Abu Bakr al-Baghdadi took

\footnotetext{
${ }^{984}$ David J. Wasserstein, Black Banners of ISIS: The Roots of the New Caliphate (New Haven and London: Yale University Press, 2017), p. 1.

985 Howard J. Shatz and Erin-Elizabeth Johnson, The Islamic State We Knew (Santa Monica, CA: Rand Corporation, 2015), p. 1.

986 Shatz and Johnson, The Islamic State We Knew, p. 1.

987 Shatz and Johnson, The Islamic State We Knew, p. 1.

${ }^{988}$ Shatz and Johnson, The Islamic State We Knew, p. 2.
} 
control. ${ }^{989}$ When ISIS captured Mosul in 2014, al-Baghdadi victoriously renamed the group the Islamic State and declared publicly that he was reinstating the Islamic caliphate and declaring himself the Caliph. ${ }^{990}$ The Islamic State partnered with al-Qaeda in Iraq during the early to mid-years of the war. The terror group suffered several defeats during this time because of their loss in popular Sunni support. ${ }^{991}$ This support fell through, in part, because of their ruthless policies. Most outsiders at the time thought it would be "reasonable to expect the Islamic State would want to avoid another Sunni Awakening. But instead of limiting its brutality, the Islamic State doubled down." ${ }^{\circ 92}$ Under alBaghdadi's command, the Islamic State publically executed any person suspected of aiding U.S., Coalition, or Iraqi forces. ${ }^{993}$ In perhaps a first for al-Qaeda, their leadership very publically broke ties with the Islamic State because of the group's "notorious intractability... [And] most extreme of the Islamist groups was the fighting in Syria [and Iraq]. ${ }^{9994}$ By the end of 2017, the Islamic State controlled an area the size of the U.K. and a population of about eight million..$^{995}$

\footnotetext{
${ }^{989}$ Shatz and Johnson, The Islamic State We Knew, p. 2.

${ }^{990}$ Michael Georgy and Maher Chmaytelli, "From 'Caliph' to Fugutive: IS Leader Baghdadi's New Life on the Run,” Reuters, June 14, 2017, Accessed on August 8, 2018.

${ }^{991}$ Shatz and Johnson, The Islamic State We Knew, p. 2.

${ }^{992}$ Shatz and Johnson, The Islamic State We Knew, p. 5.

${ }^{993}$ Loretta Napoleoni, ISIS: The Terror Nation (New York: Seven Stories Press, 2017), p. 25.

${ }^{994}$ Liz Sly, "Al-Qaeda disavows any ties with radical Islamist ISIS group in Syria, Iraq" The Washington Post, February 3, 2014. URL: https://www.washingtonpost.com/world/middle east/al-qaeda-disavows-anyties-with-radical-islamist-isis-group-in-syria-iraq/2014/02/03/2c9afc3a-8cef-11e3-98abfe5228217bd1_story.html?noredirect=on\&utm term=.6b053c02ac73.
}

${ }^{995}$ David J. Wasserstein, Black Banners of ISIS: The Roots of the New Caliphate (New Haven and London: Yale University Press, 2017), p. 57. 
The Islamic State had a four-pronged strategy vis-à-vis its domination of Iraq and Syria. This included securing financial resources, defining an organizational hierarchy for governance, recruitment and propaganda as a means of sustaining its organizational needs, and finally to act with utmost speed. ${ }^{996}$ The depth and detail of IS's strategic plan supports the nation that their organization has been highly effective and autonomous of outside cooptation. The Islamic State's financial plan was to raise funds domestically to ensure their autonomy from outside state-sponsors. ${ }^{997}$ Their revenue came primarily from oil trafficking, extortion, the sale of high priced stolen goods and artifacts, and other typical forms of racketeering and criminal behavior. ${ }^{998}$

The Islamic State possessed a great deal of professionalism, as it pertains to political and military command structures. The group's organizational strategy was based on security, sharia law, military preparedness, and the administration of conquered territory. ${ }^{999}$ In this sense the group's structure mimicked that of a nation-state, with "lower-level units reporting to upper-level units." 1000 In fact, the bureaucratic organization became so refined that IS's police force was issuing speeding tickets in their occupied territory to person's violating motor vehicle laws. ${ }^{1001}$

\footnotetext{
${ }^{996}$ Shatz and Johnson, The Islamic State We Knew, passim.

${ }^{997}$ Shatz and Johnson, The Islamic State We Knew, p. 2.

${ }^{998}$ Shatz and Johnson, The Islamic State We Knew, p. 3.

999 Shatz and Johnson, The Islamic State We Knew, p. 9.

${ }^{1000}$ Shatz and Johnson, The Islamic State We Knew, p. 3.

1001 Paul Szoldra, "Here's What a Traffic Ticket Looks Like from The "Islamic State," Business Insider, September 4, 2014. URL: http://www.businessinsider.com/is-traffic-ticket-2014-9.
} 
The Islamic State built up an intense propaganda and recruitment network. This was a virtual network that allowed IS to reach the furthest corners of the globe. ${ }^{1002}$ Over a ten-month period between 2014 and 2015 IS opponents online typically outnumbered their supporters ten to one. ${ }^{1003}$ With these odds we would expect IS detractors to have a greater online presence than their supporters. This was not the case, so much so that IS supporters regularly out tweeted opponents by 50 percent per day. ${ }^{1004}$ There were "more than 90,000 IS-affiliated twitter accounts in existence." ${ }^{1005}$ In 2014, of this number, about 46,000 individual twitter accounts were designated as "hyperactive users," meaning they pushed a "high volume and concentrated bursts of tweets to help land ISIS hashtags and messages on top trending charts."1006 All of which culminated in IS's final strategy of acting fast to take as much land, resources, and people in as little time as possible. This strategy on the part of IS was aided by the international community's "wait-and-see approach" to the crisis. ${ }^{1007}$ That said, none of this would have been possible without fighters. Since 2011 there have been over 30,000 foreign fighters who have converged on Iraq and Syria. ${ }^{1008}$

\footnotetext{
1002 Shatz and Johnson, The Islamic State We Knew, p. 6.

1003 Elizabeth Bodine-Baron, Todd C. Helmus, Madeline Magnuson, Zev Winkelman, "Examining ISIS Support and Opposition Networks on Twitter” (Santa Monica, CA: Rand Corporation, 2016), p. xi.

${ }^{1004}$ Bodine-Baron et al., "Examining ISIS Support and Opposition Networks on Twitter,” p. xi.

1005 Covarrubias et al., The New Islamic State, p. 188.

1006 J.M. Berger and Jonathon Morgan, "The ISIS Twitter Census: Defining and Describing the Population of ISIS Supporters on Twitter,” Brookings Institution, No. 20, March 2015.

${ }^{1007}$ William McCants, The ISIS Apocalypse: The History, Strategy, and Doomsday Vision of the Islamic State (New York: St. Martin's Press, 2015), p. 155.

1008 Richard Norton-Taylor, "Up to 30,000 Foreign Fighters Have Gone to Syria and Iraq Since 2011 Report" The Guardian, November 17, 2015.
} 


\section{CHAPTER VII: CONCLUSION}

"The Ethnonationalism aspirations and national-security doctrines of the major powers and their proxies have been deadly for millions of minority leaders, members of indigenous peoples, and war-ravaged communities... A new cosmopolitical order promises to interrupt this cycle by outlawing war and promoting the peaceful development of the earth."

- Hannibal Travis 1009

\section{Introduction}

In the newly published edited volume Perpetrators and Perpetration of Mass Violence, Scott Straus poses the question, "Is a comparative theory of perpetrators possible?"1010 Answering this question was, in fact, the primary aim of this dissertation. The evidence in this dissertation suggests a comparative theory of perpetrators is, not only possible, by probable. As I have argued in chapter two, genocidal violence should be examined in relation to other forms of extreme violence. That is why I conceptualized and operationalized the term "mass political violence." The use of this new term enables broader comparative analysis of mass violence episodes, by avoiding the politically charged application of the political-legal term genocide.

There are four central conclusions of this dissertation. First, when assessing the severity and destructive power of each perpetrator category, we must use both absolute

\footnotetext{
1009 Hannibal Travis, Genocide, Ethnonationalism, and the United Nations: Exploring the Causes of Mass Killing Since 1945 (New York and London, Routledge, 2013), p. 177.

1010 Scott Straus, "Is a comparative theory of perpetrators possible?" in Timothy Williams and Susanne Buckley-Zistel, Perpetrators and Perpetration of Mass Violence: Action, Motivations and Dynamics (London and New York: Routledge, 2018), p. 204-209.
} 
and relative thresholds. Neither on its own is sufficient for understanding why and how perpetrators target and eliminate vast segments of society. Professional observers of mass killing will naturally ask: which perpetrator type is the most violent? Which category is generally the deadliest form? There are a number of avenues to answering these questions. First and foremost, as genocide theorist and political violence scholars, we should not be in the business of comparing acts of depravity based purely on death tolls, as if we were comparing the trivial differences among lump sum lottery payouts to winners. Every episode of violence, including those that claim as few as one life is profoundly monumental. To flatly declare one episode to epitomize evil and others to be of lesser brutality is problematic at the least, and insensitive at most. Nonetheless, as social scientists, we must establish some form or benchmark to compare violent episodes. Two such measures include absolute casualty counts and percentage casualty measures. First, as described in chapter two and reiterated in this chapter, one measure of mass political violence resides in establishing thresholds of violence; to distinguish between normal levels of political violence and extreme violence. In this dissertation, I set forth the lowest disciplinary threshold to date, 10,000 victims killed within a 12-month span. Inevitably the first manner by which we can compare the Holocaust with the Rwandan genocide, or Boko Haram with the Islamic State, is through counting civilian and non-combatant casualties. Simply counting the number of victims targeted, purged, cleansed, disappeared or murdered is one technique to establish quantifiable benchmarks for comparison. Using this metric, we can carefully conclude that state actors (category of perpetrator "a" see Table 3.1) are often the most lethal. Examples of these perpetrators include the Soviet communists and Khmer Rouge of Cambodia. When state actors partake 
in mass political violence, they often possess the most lethal means of enacting violence on a large-scale. Lethality is not equivalent to severity of evil actions. This is not a moral claim of rank-ordering case studies. This numeric measure of lethality in terms of victim deaths is solely used for establishing one benchmark for scholarly comparison, and not for moral judgments or moral comparisons of malevolent events.

While counting casualties is an inevitable exercise, absolute numbers do a disservice to violent episodes that involve substantially smaller target groups. Therefore, a second metric may be utilized in the instances where victim groups are a small minority or substantially small population; here a percentage indicator should be calculated. Examples where a percentage indicator is most useful would be in comparing the Holocaust and Rwandan genocides to that of China's Cultural Revolution and Great Leap Forward. Perhaps a better reflection of Nazi genocidal impact calculating the percentage of Jews killed out of the total under within the Nazi reach. In this instance. The percentage would reflect in even more severe terms the destructive power of Hitler's antiSemitic regime and associated militias. In Rwanda, the Tutsi population is not satisfactorily known. Nevertheless, based on quasi-accurate census data, the Tutsi minority population in 1994 was approximately 10-15 percent of the national population. The genocide against the Tutsi would nearly eradicate this ethnic minority from the Rwandan countryside in whole. With estimates of 500,000 to 800,000 Tutsis murdered, the numeric casualty count pale in comparison to those of China's Cultural Revolution or the Great Leap Forward. However, this number reflects a near eradication of this ethnic minority group that in fact suffered a complete loss at the hands of perpetrators more than two decades ago. Depending on comparative analysis, genocide scholars should use 
either a numeric or percentage indicator in assessing the seriousness of each mass political violence episode. Anything less would demean those who perished at the hands of perpetrators and undermine unbiased research into the consequences of genocide and mass political violence.

The second conclusion based on the analysis in this dissertation is that we must question the so-called unitary role of the state. Since 1945, much of the scholarship on the Holocaust and genocide has revolved around the role of the state. It would be academic malpractice to ignore the institutional drivers of mass political violence, particularly, of the twentieth century's most violent bureaucratic genocide. However, the extant literature has sidelined two important questions. First, what is the comparative influence of the state across genocides and mass political violence episodes? Existing scholarship, to a large degree, has lumped the involvement of the state into one category: primary perpetrator. By unpacking the influence, capacity, process, and function of the state in various cases of mass political violence, we can see how the state's involvement differs. The second neglected area of research here, relies on the exclusion of non-state actors from analysis. Stemming from this over concentration on state actors, we have largely neglected the role of non-state actors in committing genocide and mass political violence. This dissertation addresses both these concerns. As Richard Haass argues, our "world [is] in disarray."1011 In the last thirty years we have seen a global explosion in the number of failed and collapsed states. It is these vast swaths of territory that statesponsored groups and non-state actors are most likely to emerge and use heinous tactics,

${ }^{1011}$ Richard Haass, A World in Disarray: American Foreign Policy and the Crisis of the Old Order (New York: Penguin Books, 2017). 
like mass political violence. Therefore, theory building and theory testing within Genocide Studies must evolve to include this new dimension. It is not only imperative we do so for historical accuracy but also in diagnosing states that are prone to extreme violence.

The third conclusion is that perpetrator type implicitly limits the scope of violence and target group(s). Mass political violence usually stems from some form of state involvement but not always (see Table 3.2). When the state is the sole perpetrator of violence the target group is likely to be a large segment of society. State perpetration of mass political violence is when government agents, bureaucrats, formal institutions, and regime hardliners are motivated and directed to eliminate a target group that is perceived to be a threat. Chapter four unpacks this most devastating form of mass political violence in the Soviet Union and Cambodian case studies. As was seen here, state perpetrators enacted brutally harsh conditions on vast national and sub-national populations that were designed to suppress, coerce, and annihilate dissidents. This type of mass political violence is empirically different than what transpired during the Holocaust and in 1994 Rwanda. When state-society coalitions engage in this level of violence they will typically target an ethno-religious population compared to state perpetrator's war on society writ large. This is likely the case because state-society coalitions - as were present in Nazi Germany and Rwanda - require both governmental and societal mass mobilization. This dual effort is most likely to occur when the target group is used as a scapegoat for the nation's ill-health. Finally, both state-sponsored groups and non-state actors are likely to emerge in socio-political contexts that limit their overall sustainability over time. 
The final conclusion generated from the evidence of this dissertation is that there are variations between perpetrator categories (i.e., state perpetrators and state-society coalitions) and there is variation within each perpetrator category (see Figure 7.1). This is vitally important. Variation exists both between and within these perpetrator types. Tables 3.1 and 3.2 represent mass political violence perpetrator ideal types, in an abstract form. When these events are witnessed in the social world, each case is, to some extent, sui generis.

\section{Figure 7.1}

\section{Mapping Case Studies of Mass Political Violence by Perpetrator Ideal Type}

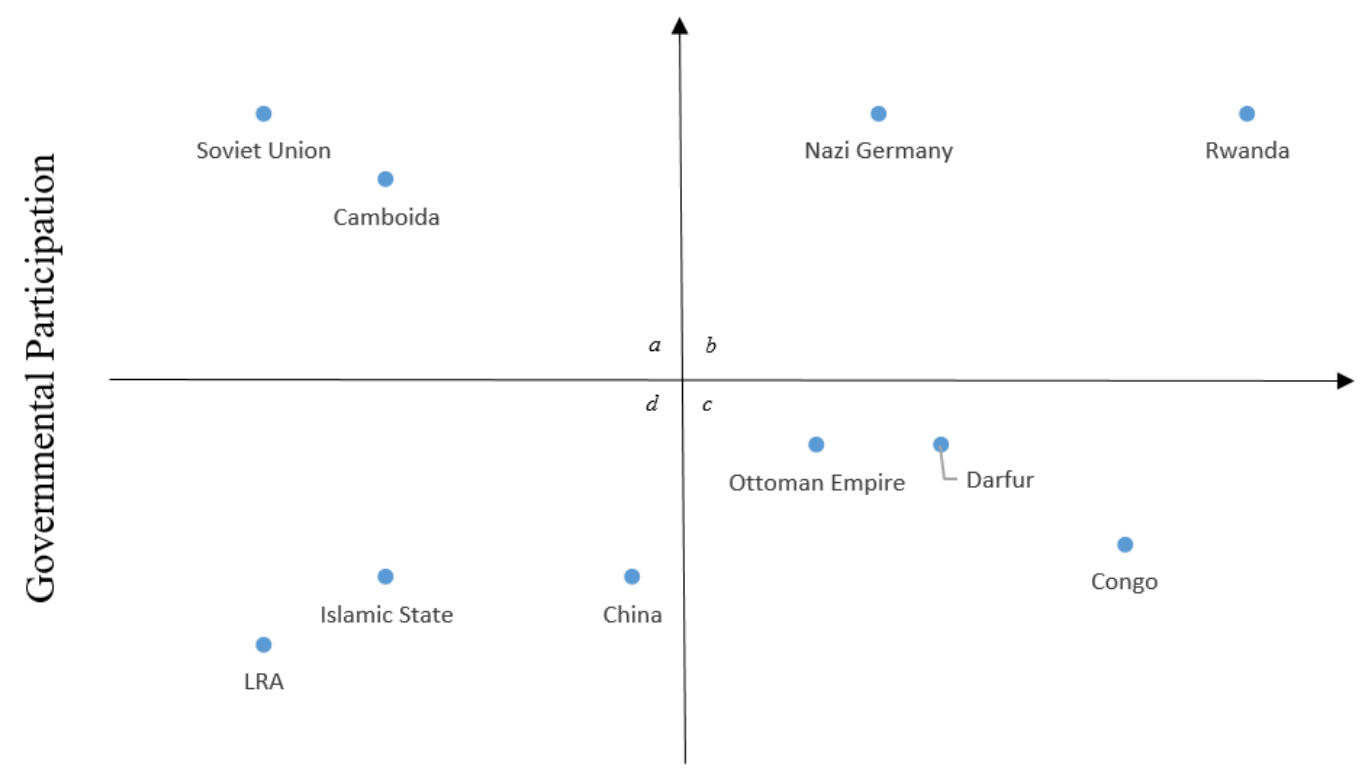

Societal Participation

Legend: a) state perpetrators; b) state-society coalitions; c) state-sponsored groups; d) non-state actors

For instance, in both Nazi Germany and Rwanda's mass political violence episodes there was vast societal support - taking many forms- for the violence enacted on target populations. That said, in the case of Rwanda, I argue that there was even more widespread 
societal support and mass mobilization for killing the Tutsi minority than was seen in the Holocaust and other Nazi genocidal atrocities. This variation is important for understanding the factual record of violence and for theorizing about this perpetrator category. Why was it that more civilians participated in a state-society coalition in Rwandan than Nazi Germany? The answer may reside in the strength of governmental institutions for starters. Nazi Germany under Adolf Hitler had become one of only a handful of countries in the modern world to reach a totalitarian state - a governmental structure where the regime, headed often by a charismatic leader, controls both the hearts and minds of its people. This was clearly present in Hitler's Germany and was not present in Rwanda. Under Habyarimana's regime and his successors' Rwanda became a vast authoritarian state but never reached the level of governmental and social control witnessed decades earlier in Germany. Therefore, this single factor, among many, may lead to the disparities in social participation in mass political violence. What is fundamentally important for the reader to understand is, that yes, there are comparative perpetrator ideal types that reflect and exhibit similar characteristics and qualities. Second, within this initial grouping of case studies exists further variation that should be explored and understood on a deeper level, both for the purpose of theory building and historical accuracy.

\section{Why Rely on a Dynamic Structural Approach to Mass Political Violence?}

A common theme throughout this dissertation is that mass political violence perpetrators may engage in large-scale violence against a target group for a singular reason, a group of reasons, or for no reason at all. Mass political violence, as assumed in this dissertation, is largely employed for instrumental means by perpetrators. To emphasize, 
existing theories of genocide and mass atrocities revolve in some way around the assessment of perpetrator motivations coupled with their ability to enact violence. Helen Fein, Barbara Harff, Ted Robert Gurr, Donald Beachler, Vahakn Dadrian, or Benjamin Valentino, to name but a few prominent scholars, largely segregate episodes into categories based on motivations/scenarios. Valentino developed six types of mass killing episodes in a descriptive fashion to address the $20^{\text {th }}$ century's largest episodes of human destruction. While his work has greatly advanced our understanding of the "strategic" motivations of perpetrators it has limitations in assisting policy makers to develop early warning mechanisms for genocide/mass atrocity onset. My research endeavors to bridge this knowledge gap.

When parsing group or individual means of violence, one cannot escape the perennial debate on rationality. Are individuals who enact violence against one another for genocidal or otherwise insidious reasons "rational"? In domestic legal systems, we have carved out a defense for reasons of "temporary insanity." Similarly, authors like Christian Gerlach contend, this temporary fever pitch may occur at group levels too, a process he refers to as "extremely violent societies." Many social scientists have weighed in on the debate over rationality and its applicability to the social world. As part of my "dynamic structuralist" approach, I make the assumption that individuals may engage in, coerce, participate in, or support violence for many different reasons, or simply no reason at all. At the same time, this approach is similar to what Benjamin Valentino refers to as the "strategic perspective." Valentino argues that individuals employ mass killing when they perceive it to be the most efficient means of accomplishing their desired goals and 
objectives. Additionally, Valentino argues that, because of the individual and social costs mass killing entails, such strategies are likely to be a last resort and not the first option.

There are two general understandings of rationality. The first and most prevalent use is taken from economics. Economic rationality is used when individuals calculate the benefit-cost analysis of a decision, using a transactional approach to maximizing one's gains. In other words, weighing the costs and benefits and making decisions based upon the net effect those choices provide. If leader A chooses option 1, she may endure $\mathrm{X}$ and Y costs and benefits, but if leader A selects option 2, she may obtain greater values on each. Most social science research in politics references, in some form, economic rationality, as is simplified here. ${ }^{1012}$ The second meaning/category, and my point of focus here, is strategic or instrumental rationality. This more nuanced perspective views an individual's actions as "rational" if her actions overlap with her beliefs, ideology, or goals. This means, an individual may be "rational," even if their chosen path negatively affects leaders in seemingly illogical ways. Perhaps the ideal case for explaining strategic rationality (or the strategic perspective as Valentino prefers) is the Holocaust.

On September 1, 1939 the German Wehrmacht, armed forces, invaded Poland. By 1942, "after three years of war... 75 percent of the Jews who would be murdered in the Holocaust were still alive." 1013 Within one year, of those Jews who would be mass

\footnotetext{
1012 For a comprehensive analysis of economic rationality read Paul Weirich, "Economic Rationality" in Alfred R. Mele and Piers Rawling eds., The Oxford Handbook of Rationality (Oxford, Oxford University Press, 2004).

1013 Doris L. Bergen, War \& Genocide: A Concise History of the Holocaust (Rowman \& Littlefield Publishers, Inc., New York 2009), p. 182.
} 
murdered, 75 percent were dead. ${ }^{1014}$ By the end of 1944, many Germans entertained the idea that they could lose the war. With US and Allied forces advancing in the west and the Soviets storming across the Eurasian plains in the east, Hitler's "thousand year Reich" was beginning to feel severe pressure in the homeland. Between 1944 and 1945, the US and Royal Air Forces dropped 1.4 million tons of bombs on German-held territories. ${ }^{1015}$ With vast shortages in the German labor market, Nazis increasingly relied on forced laborers towards the end of the war. ${ }^{1016}$ This raises the question, why did Hitler divert vital men and material away from the war effort to continue his campaign of mass murder? Even once defeat became clear, German personnel, weapons, material, resources, and precious time went to killing "undesirables," rather than trying to win the war or sue for a peaceful settlement of hostilities. Economic rationalists have a difficult time explaining why Hitler would choose to divert vital material away from winning the war in lieu of genocidal campaigns. One argument is that, by this point, Hitler was no longer of sound mind, and was behaving irrationally because of mental illness. Thereby arguing that he was no longer capable of making "rational" decisions, though this argument lacks evidence in many respects. ${ }^{1017}$

\footnotetext{
${ }^{1014}$ Bergen, War \& Genocide, p. 183.

${ }^{1015}$ Bergen, War \& Genocide, p. 216.

1016 Wolf Gruner, Jewish Forced Labor Under the Nazis: Economic Needs and Racial Aims, 1938-1944, trans. Kathleen M. Dell'orto (New York: Cambridge University Press, 2006).

1017 The reader may ask, what is the difference between "rational" and "reasonable" decisions? Both terms are "derived from the same noun, and designating a conformity with reason, would pose no problem if the two terms were interchangeable." In essence, rational behavior is defined by one's behavior that conforms to a set of principles and "chooses ends through knowledge of cause... [and] not allowing oneself to be held or led astray by the emotions or passions." On the contrary, reasonable behavior can be assessed as one operating in accordance with common sense decisions, meaning, "...for what is acceptable in his milieu and even beyond it, for what should be accepted by all." For a complex, sophisticated discussion of the many unique
} 
A strategic rationalist would assert, perhaps winning the war was not Hitler's first priority. Due to his severe hatred of the Jewish people and other "non-desirables," he opted to devote time and resources to eradicating this "scourge" from the face of the earth immediately, rather than wait until the war's conclusion. There is ample evidence to support Hitler's prioritization of genocidal policies over conventional war fighting efforts. This prioritization of interests is "rational" if Hitler believed his highest priority was to wage war against domestic groups then opposing states. Even if these efforts of mass extermination cost Germany the war, his strategic goals were met, that being a war against European Jewry and other "asocial” groups.

As noted above, perpetrators enact violence for a variety of reasons. Most important is to assess under what conditions people carry out violence rather than unpacking individual or collective motives. Violence may be a means to an end or an end in itself. This distinction does not matter to victims or myself. For violence to reach a massive level (i.e., 10,000 victims within a 12-month period), there must be certain factors present that enable a transition from "normal" levels of political violence to mass political violence. Understanding and explaining these factors are my principal concern.

Therefore, why a dynamic structural approach? There remains a collective misunderstanding of pertinent risk factors for genocide and mass political violence, which presents vast problems in explaining, understanding, and forecasting such events. The following is a summary of major non-mutually exclusive variables that have been used to

characteristics in each term and for analysis of the above quoted material see Chaim Perelman, "The Rational and the Reasonable" Philosophic Exchange 10:1 (1979), p. 29-34. 
understand macro-, meso-, and micro-levels influences on genocide. This is not an exhaustive list: ${ }^{1018}$

- Armed conflict (or) war

- Assassinations

- Authoritarianism

- Convenience and opportunity

- Deep-seated hatreds

- Dehumanization and deindividuation

- Discriminatory legislation

- Economic causes (numerous)

- Ethno-cultural elite

- Existing discrimination against a particular group

- Fear (simple and of pollution)

- Fragile, weak or state collapses

- Frustration-aggression

- Government capabilities

- Greed and grievance

- High infant mortality

- Ideology (exclusionary or transformative)

- Large-scale instability

- Low-trade openness

- Nonviolent protests

- Outlawing political parties

- Percentage of GDP spent on military

- Polarized society

- Political and social upheaval

- Prior genocide or mass atrocities

- Realpolitik and risk minimization

- Regime type (all)

- Religious motivations

- Revenge

- Rigged elections

- Sadism

1018 Compiled from a host of sources with special attention to the following: Scott Straus. February 2014. Fundamentals of Genocide and Mass Atrocity Prevention. Washington, D.C.: United States Holocaust Memorial Museum; Madeline K. Albright and William S. Cohen, eds. 2008. Preventing Genocide: A Blueprint for U.S. Policymakers. Washington, D.C: United States Holocaust Memorial Museum, The American Academy of Diplomacy, and the Endowment of the United States Institute of Peace; and secondary attention to the following reference material: Harff, 2003, "No Lessons Learned from the Holocaust."; Chirot and McCauley, 2006, Why Not Kill Them All?; Valentino, 2004, Final Solutions; Gerlach, 2010, Extremely Violent Societies; Rummel, 1994, Death by Government; Midlarsky, 2005, The Killing Trap. 
- Size of the military

- State capacity

- Stockpiling weapons

- Totalitarianism

- Triggering events

- Youth indoctrination

As is readably apparent, we have an overabundance of control and causal variables to consider when assessing the complex causal mechanisms that lead to genocide and mass atrocities. Scholars seeking to make a contribution to this sub-field must address these issues and assign credibility to certain variables over others. This inherently provides a lacuna in our understanding of these processes and inability to narrow the field of study.

To identify societies at risk of mass political violence (MPV), we might employ a criminological perspective by asking: what are the motives, means, and opportunities for perpetrators in a given context? Pinpointing perpetrator ideological beliefs would be one priority in unpacking possible motives. Harken back to pre-war Germany where society was imbued with notions of antisemitism that permeated nearly all aspects of life. Germans were taught to blame Jews for Germany's defeat and subsequent decline after World War I. This scapegoating came from the administrative state and was echoed in many churches across the continent. National Socialisms of the 1930s took advantage of this particularly violent strain termed "eliminationist antisemitism" by tapping into preexisting beliefs, values and attitudes towards Jews. This deep ideological belief, held by many, could be a key motivating factor in the Holocaust and other Nazi genocidal atrocities. That said, antisemitism by itself is not solely sufficient in explaining the totality of National Socialist violence. Antisemitism was indeed a unifying credo among many Germans. However, running parallel to this attitude was individual psychological 
reasons for participating. Most Germans viewed the dispossession of Jewish businesses and property as "a once-in-a-lifetime opportunity" to enrich themselves at the expense of their Jewish neighbors. In many of these cases German proprietors may have sympathized with anti-Semitic attitudes but individual financial greed coupled with opportunity could be the tipping point to violence. Greed is just one of dozens of psychological dispositions that have been catalogued to encourage people to commit violence against another.

Most theories revolve in some way around the assessment of perpetrator motivations coupled with their ability to enact violence (i.e., their means). There is often a confluence of motives as discussed above. Any cursory search of the academic literature on the causes of genocide would return thousands of hits explaining in granular detail ideological motivations of individuals and societies. However, investigating individual motives for violence can be a slippery slope. Many social scientists, including myself, contend human beings wield violence for a variety of reasons. Perhaps most pertinent to my framework, is violence wielded in a specific, quasi-organized fashion that result in massive levels of fatalities. If operating from the assumption that violence is first and foremost instrumental, thereby tied to elite or mass goals, establishing a unified theory of mass political violence onset (i.e., pre-violence) based on the "strategic" goals of individuals is inherently difficult. As human goals may change from decade to decade or even week to week. Rather than asking why people kill - because such a list is never ending - we should ask under what conditions do people kill? Understanding the conditions that give rise to such extreme events will yield analytically more fruitful responses than scholarly attempts at unpacking the political psychology that is required in 
predicting perpetrator motives. Therefore, isolating particular motives is not the most efficient way of identifying societies at risk of mass political violence.

Because agents are largely bound by their physical and to some extent social environment, theorizing these constraints is vital to explaining why violence occurs or is prevented in any given context. In other words, rather than emphasizing "motives and means," I stress the role "opportunity" plays in the development of violence. The social scientific term for my approach would be "dynamic structuralism." I define dynamic structuralism as the need to examine both slowly changing variables - i.e., structural factors - like a regime's military capacity, ideology, infrastructure and bureaucratic state capacity, civic tolerance, or social cleavages with dynamic processes such as exogenous/endogenous shocks to society as in terrorism, armed conflict, assassination, or economic collapse.

Therefore, in assessing state-society relations, I use three structural variables combined with estimates of perpetrator tactics and stratagems (dynamic processes) to determine the likelihood of MPV onset. MPV can materialize during armed conflict or its absence, in developed or developing economies, or in heterogeneous or homogenous states. Thus, rather than over complicating our model of MPV onset I rely on three principal factors that are most likely to enable perpetrators of MPV to emerge. Savvy perpetrators use state and societal indicators as a means of triangulating their window of opportunity. Any perpetrator dead set on enacting violence can attempt so at any time, irrespective of these social structures. However, for violence to reach a level of 10,000 or more victims within a 12-month period, these structures (i.e., a) regime power, b) state 
capacity, and c) social appetite for violence) must interact in specific ways to facilitate such desires.

\section{Expectations of Mass Political Violence in a $21^{\text {st }}$ Century World}

Given what has been iterated throughout this dissertation, I argue that mass political violence is not a random or rare phenomena. It is the result of widespread sociopolitical changes that originate from a variety of state and societal involvement in the perpetration of violence. As our political world continues to collapse in territories throughout the world we will likely see more, not less, mass political violence episodes. State perpetrators have been and are likely to be the most common category of perpetrator witnessed in our global society. Separate from this, I argue that we are most likely to see an increase in the number of state-sponsored groups and non-state actors who turn toward mass political violence as a means of achieving their desired social, political, economic, or territorial conquests. Though bleak, the future does not look to be different than our most recent experiences in widespread in mass atrocities. Genocide and mass political violence is a one hundred percent preventable phenomenona. Unlike natural disasters, this human phenomenona is entirely of our own creation. Therefore, if we desire a world with fewer mass political violence episodes it is up to us as human beings to be make this utopian vision a reality. 


\section{LIST OF REFERENCES}

“Adolf Eichmann.” 2018. United States Holocaust Memorial Museum. Accessed April 17, 2018. URL: https://www.ushmm.org/wlc/en/article.php?ModuleId=10007412.

"Collaboration." 2018. United States Holocaust Memorial Museum. Accessed on April 7, 2018. URL: https://www.ushmm.org/wlc/en/article.php?ModuleId=10005466.

"Einsatzgruppen (Mobile Killing Units)." 2018. United States Holocaust Memorial Museum. Accessed on April 18, 2018. URL:

https://www.ushmm.org/wlc/en/article.php?ModuleId=10005130.

"From the Editor: the eagles and the worms: on the future agenda of genocides studies." 2001. Journal of Genocide Research 3 (3): 345-346.

"From the guest editors: Raphael Lemkin: the "founder of the United Nation's Genocide Convention" as a historian of mass violence." 2005. Journal of Genocide Research 7 (4): 447-452.

"International Criminal Court Investigations Uganda." 2018. Global Policy Forum. Accessed: June 9, 2018. URL: https://www.globalpolicy.org/international-justice/theinternational-criminal-court/icc-investigations/uganda.html.

"Kony's LRA has killed more than 100,000: UN." 2013. The Denver Post. Denver, Colorado, May 20, 2013. URL: https://www.denverpost.com/2013/05/20/konys-lra-has-

killed-more-than-100000-un/.

"Kristallnacht." 2018. United States Holocaust Memorial Museum. Accessed on April 30, 2018. URL: https://www.ushmm.org/wlc/en/article.php?ModuleId=10005201.

"Martin Niemöller: "First they came for the Socialists..." 2018. United States Holocaust Memorial Museum, accessed on April 30, 2018. URL:

https://www.ushmm.org/wlc/en/article.php?ModuleId=10007392.

"Nazi Camps." 2018. United States Holocaust Memorial Museum. Accessed on April 7, 2018. URL: https://www.ushmm.org/wlc/en/article.php?ModuleId=10005144.

"Operation Reinhard (Einsatz Reinhard)." 2018. United States Holocaust Memorial Museum. Accessed April 17, 2018. URL:

https://www.ushmm.org/wlc/en/article.php?ModuleId=10005195.

"Outreach Programme on the Rwanda Genocide and the United Nations." 2018. The United Nations, URL:

www.un.org/en/preventgenocide/rwanda/education/rwandagenocide.shtml. 
"Press Releases: Collaboration and Complicity during the Holocaust." 2018. United States Holocaust Memorial Museum. Issued May 1, 2015. Accessed on April 19, 2018. URL: https://www.ushmm.org/information/press/press-releases/collaboration-andcomplicity-during-the-holocaust.

"Profile: Guatemala's Efrain Rios Montt." 2013. BBC News. May 11, 2013. Accessed on November 8, 2017. URL: http://www.bbc.com/news/world-latin-america-22486387.

"Profile: The Lord's Resistance Army." 2014. Al Jazeera. May 6, 2014. URL: https://www.aljazeera.com/news/africa/2011/10/2011101418364196576.html.

"SS Police State." United States Holocaust Memorial Museum. Accessed on April 7, 2018. URL: https://www.ushmm.org/outreach/en/article.php?ModuleId=10007675.

"Transcript of Bush's UN Address." 2004. CNN.com. September 21, 2004. Accessed on August 21, 2018. URL: www.cnn.com.2004/US/09/21bush.un.transcript/index.html.

"Wannsee Conference and the "Final Solution."' United States Holocaust Memorial Museum. Accessed on May 2, 2018. URL:

https://www.ushmm.org/wlc/en/article.php?ModuleId=10005477.

Ad Hoc Committee, supra note 3, Sixth Session, 13th meeting. 1948. UN Doc E/AC.25/SR.13.

Adamu, Mamman Musa. 2008. "An Appraisal of the Crisis in Darfur in Western Sudan and the Prospect for a Lasting Peace." African Research Review 2 (3): 315-333.

Adler, Nanci. 1993. Victims of Soviet Terror: The Story of the Memorial Movement. Westport, CT: Praeger.

African Rights, with photographs by Jenny Matthews. 1997. Resisting Genocide: AprilJune 1994. London: African Rights.

Al Jazeera. "Erdogan: Armenia 'genocide' used to blackmail Turkey." 2006. Al Jazeera. June 4, 2006. URL: http://www.aljazeera.

Albright, Madeline K. and William S. Cohen, eds. 2008. Preventing Genocide: A Blueprint for U.S. Policymakers. Washington, D.C: United States Holocaust Memorial Museum, The American Academy of Diplomacy, and the Endowment of the United States Institute of Peace.

Allen, Tim and Koen Vlassenroot eds., 2010. The Lord's Resistance Army: Myth and Reality. London and New York: Zed Books. 
Andreopoulos, George ed., 1994. Genocide: Conceptual and Historical Dimensions. Philadelphia: University of Pennsylvania Press.

Angier, Carole. 2002. The Double Bond: Primo Levi a Biography. New York: Farrar, Straus and Giroux.

Anthony, Andrew. 2009. "Interview: We'd walk to the field to work and see the bodies. They left them there to scare us." The Guardian. November 14, 2009. Accessed on March 17, 2018.

Applebaum, Anne. 2017. Red Famine: Stalin's War on Ukraine. New York: Doubleday.

Arendt, Hannah. 1964. Eichmann in Jerusalem: A Report on the Banality of Evil. New York: Viking Press.

Arendt, Hannah. 1951. The Origins of Totalitarianism. New York: Harcourt Brace Jovanovich, Inc.

Arendt, Hannah. 1970. On Violence. New York: Harcourt Brace Jovanovich, Publishers.

Atkinson, Ronald R., 2009. "From Uganda to the Congo and Beyond: Pursuing the Lord's Resistance Army.” International Peace Institute.

Baker, Patrick S. 2013. "Mercenaries and the Congo Crisis." Saber and Scroll. 2 (1): 89103.

Barta, Tony. 2008. Relations of Genocide: Land and Lives in the Colonization of Australia. Los Angeles, CA: Sage.

Bartov, Omer, eds. 2000. The Holocaust: Origins, Implementation, Aftermath. London and New York: Routledge.

Bartrop, Paul R. and Steven Leonard Jacobs. 2011. Fifty Key Thinkers on the Holocaust and Genocide. London and New York: Routledge.

Bartusevicius, Vincas, Joachim Tauber, and Wolfram Wette. 2003. Holocaust in Litauen: Krieg, Judenmorde und Kollaboration im Jahre 1941. Cologne: Böhlau.

Bassil, Noah R. 2013. The Post-Colonial State and Civil War in Sudan: The Origins of Conflict in Darfur. London: I.B. Tauris.

Bauman, Zygmunt. 2007 [1989]. Modernity and the Holocaust. Maldon, MA: Polity Press. 
Baumeister, Roy F. 2002. "The Holocaust and the Four Roots of Evil," in Leonard S. New man and Ralph Erber eds., Understanding Genocide: The Social Psychology of the Holocaust. Oxford and New York: Oxford University Press.

Bavier, Joe. 2011. "Victims of Uganda's Lord's Resistance Army." The Telegraph. February 18, 2011.URL:https://www.telegraph.co.uk/news/worldnews/africaandindianocean/uganda/8 331004/Victims-of-Ugandas-Lords-Resistance-Army.html.

BBC News. 2007. "World / Africa Analysis: Defining Genocide.” February 27, 2007.

Beachler, Donald W. 2011. The Genocide Debate: Politics, Academics, and Victims. Palgrave Macmillan US.

Beardsley, Major Brent. 2006. "The Endless Debate over the 'G Word.'” Genocide Studies and Prevention. 1 (1): 79-82.

Becker, Elizabeth. 1998. When the War Was Over: Cambodia and the Khmer Rouge Revolution, Revised Edition. New York: Public Affairs.

Becker, Jasper. 1998. Hungry Ghosts: Mao’s Secret Famine. Holt Paperbacks.

Bellamy, Alex. 2011. "Mass Atrocities and Armed Conflict: Links, Distinctions, and Implications for the Responsibility to Protect." Stanley Foundation, URL: http://www.stanleyfoundation.org/resources. cfm?ID=445. Ulfelder, Jay, and Benjamin Valentino. 2008. "Assessing the Risks of State-Sponsored Mass Killing." Political Instability Task Force, Washington, DC.

Beorn, Waitman Wade. 2017. "The crimes of the Wehrmacht and the Alt Right in American Reenacting." Presentation, Florida International University, Miami, FL, February 16, 2017.

Berenbaum, Michael. 2017. "Religion and the Holocaust in Contemporary Discourse." Presentation, Inaugural Suzanne R. and Dr. Lawrence M. Fishman Scholar-in-Residence, Florida International University, Miami, FL, February 14, 2017.

Bergen, Doris L. 2009. War \& Genocide: A Concise History of the Holocaust, Second Edition. New York: Rowman \& Littlefield Publishers, Inc.

Berger, J.M. and Jonathon Morgan. 2015. "The ISIS Twitter Census: Defining and Describing the Population of ISIS Supporters on Twitter," Brookings Institution, No. 20.

Bergsmo, Morten. 2009. "Intent" in Samuel Totten and Paul R. Bartrop ed., The Genocide Studies Reader. New York: Routledge. 
Berkhoff, Karel C. 2004. Harvest of Despair: Life and Death in Ukraine under Nazi Rule. Cambridge, MA: Belknap.

Bloxham, Donald and A. Dirk Moses eds. 2010. The Oxford Handbook of Genocide Studies. New York: Oxford University Press.

Bloxham, Donald. 2003. "The Armenian Genocide of 1915-1916: Cumulative Radicalization and the Development of a Destruction Policy." Past and Present 181: 141-92.

Bøås, Morten and Kevin C. Dunn eds. 2007. African Guerrillas: Raging Against the Machine. Boulder, CO: Lynne Rienner Publishers.

Bodine-Baron, Elizabeth, Todd C. Helmus, Madeline Magnuson, Zev Winkelman. 2016. "Examining ISIS Support and Opposition Networks on Twitter." Santa Monica, CA: Rand Corporation.

Boghossian, Paul 2010. "Response to my critics." Journal of Genocide Research. 12 (12): 105-112.

Boghossian, Paul. 2010. "The concept of genocide." Journal of Genocide Research. 12 (1-2): 69-80.

Bonnier, Evelina, Jonas Poulsen, Thorsten Rogall, and Miri Stryjan. May 2015. "Preparing for Genocide: Community Work in Rwanda." Presented at: ASWEDE Conference on Development Economics, SSE, and Columbia Development Colloquium.

Boyden, Jo. 2003. "The Moral Development of Child Soldiers: What Do Adults Have to Fear?" Peace and Conflict: Journal of Peace Psychology. 9 (4): 352-353.

Breitman, Richard. 1992. The Architect of Genocide: Himmler and the Final Solution. The Tauber Institute Series for the Study of European Jewry, Brandeis.

Brown, Kate. 2004. A Biography of No Place: From Ethnic Borderland to Soviet Heartland. Cambridge, MA: Harvard University Press.

Brown, Sara E. 2014. "Female Perpetrators of the Rwandan Genocide," International Feminist Journal of Politics. 16 (3).

Browning, Christopher. 1994. "Ordinary Germans or Ordinary Men,” Address and Response at the Inauguration of the Dorot Chair of Modern Jewish and Holocaust Studies. Emory University, Atlanta.

Browning, Christopher R. 2004. The Origins of the Final Solution: The Evolution of Nazi Jewish Policy, September 1939-March 1942. Lincoln, NE: University of Nebraska. 
Browning, Christopher R. The Path to Genocide: Essays on Launching the Final Solution. New York: Cambridge University Press.

Buchler, Yehoshua. 1986. "Kommandostab Reichsführer-SS: Himmler's Personal Murder Brigades in 1941.” Holocaust and Genocide Studies. 1 (1): 11-25.

Burleigh, Michael. 2000. "Psychiatry, German society and the Nazi "euthanasia" programme," in Omer Bartov eds., The Holocaust: Origins, Implementation, Aftermath (London and New York: Routledge, p. 43-62.

Burmester, H. C. 1978. "The Recruitment and Use of Mercenaries in Armed Conflicts." The American Journal of International Law. 72 (1).

Buzan, Barry and Richard Little. 2002. "International systems in world history: remaking the study of international relations" in Stephen Hobden and John M. Hobson eds.

Historical Sociology of International Relations. Cambridge: Cambridge University Press.

Carter, Peter. 1976. Mao. London: Oxford University Press.

Cell, Charles P. Revolution at Work: Mobilization Campaigns in China. New York: Academic Press.

Ch’en, Jerome eds. 1969. Mao. Englewood Cliffs, NJ: Prentice-Hall, Inc.

Chalk, Frank and Kurt Jonassohn. 1990. The History and Sociology of Genocide: Analyses and Case Studies. New Haven: Yale University Press).

Chandler, David P. 1999. Brother Number One: A Political Biography of Pol Pot. Boulder, CO: Westview Press.

Chandler, David P. 1991. The Tragedy of Cambodian History: Politics, War, and Revolution since 1945. New Haven and London: Yale University Press.

Charny, Israel W., in foreword of Alan S. Rosenbaum eds. 1996. Is the Holocaust Unique? Perspectives on Comparative Genocide. Boulder, CO: Westview Press Inc.

Charny, Israel. 1994. "Toward a generic definition of genocide," in George Andreopoulos, ed., Genocide: Conceptual and Historical Dimensions. Philadelphia: University of Pennsylvania Press.

Charny, Israel. 1982. How Can We Commit the Unthinkable? Genocide, the Human Cancer. Boulder, CO: Westview. 
Charny, Israel, ed. 1984. Toward the Understanding and Prevention of Genocide:

Proceedings of the International Conference on the Holocaust and Genocide. Boulder: Westview Press, pp 32-47.

Charny, Israel. 1994. The Widening Circle of Genocide. Piscataway, NJ: Transaction Publishers.

Chigas, George and Dmitri Mosyakov. 2018. "Literacy and Education under the Khmer Rouge," The Cambodian Genocide Program, Yale University. Accessed on March 17, 2018. URL: https://gsp.yale.edu/literacy-and-education-under-khmer-rouge.

Chirot, Daniel and Clark McCauley. 2006. Why Not Kill Them All? The Logic and Prevention of Mass Political Murder. Princeton: Princeton University Press.

Chorbajian, Levon and George Shirinian ed. 1999. Studies in Comparative Genocide. New York: St. Martin's Press, Inc.

Chossudousky, Michel. 1997. The Globalisation of Poverty: Impacts of IMF and World Bank Reforms. London and New Jersey: Zed Books; Penang: Third World Network.

Churchill, Winston. 2017. "The Atlantic Charter" Speech, July 29, 1941. The International Churchill Society. Accessed on February 3, 2017. URL: http://www.winstonchurchill.org/resources/speeches/1941-1945-war-leader?start=10.

Clarke, Stephen. 1968. The Congo Mercenary: A History and Analysis. Johannesburg: The South African Institute of International Affairs.

Collier, Paul and Anke Hoeffler. 2004. "Greed and grievance in civil war." Oxford Economic Papers. 56 (4): 563-595.

Collins, Barrie. 1998. Obedience in Rwanda: A Critical Question. Sheffield: Hallam University School of Cultural Studies.

Colombijn, Freek and J. Thomas Lindblad eds. 2002. Roots of Violence in Indonesia: Contemporary violence in historical perspective. Leiden, Netherlands: KITLV Press.

Conley-Zilkic, Bridget. 2016. "How Mass Atrocities End." World Peace Foundation. 1 (9).

Conquest, Robert. 1978. Kolyma: The Artic Death Camps. Viking Adult.

Conquest, Robert. 1990. The Great Terror: A Reassessment. New York: Oxford University Press. 
Conquest, Robert. 1986. The Harvest of Sorrow: Soviet Collectivization and the TerrorFamine. New York and Oxford: Oxford University Press.

Conquest, Robert. 1970. The Nation Killers: The Soviet Deportation of Nationalities. The Macmillan Company.

Conquest, Robert. 1960. The Soviet Deportation of Nationalities. Macmillan.

Convention on the Prevention and Punishment of the Crime of Genocide, Article 2(c).

Cook, Susan E eds. 2009. Genocide in Cambodia and Rwanda: New Perspectives, $4^{\text {th }}$ Edition New Brunswick and London: Transaction Publishers.

Cooper, Julian and Maureen Perrie eds. 1995. Soviet History, 1917-53. New York: St. Martin's Press, Inc.

Courtois, Stéphane, Nicolas Werth, Jean-Louis Panné, Andrezej Paczkowski, Karel Bartošek, and Jean-Louis Margolin, eds. 1999. The Black Book of Communism: Crimes, Terror, Repression. Cambridge, MA: Harvard University Press.

Covarrubias, Jack and Tom Lansford. 2016. The New Islamic State: Ideology, Religion and Violent Extremism in the $21^{\text {st }}$ Century. New York: Routledge.

D’Agostino, Anthony. 2011. The Russian Revolution, 1917-1945. Santa Barbara:

Praeger.

Dadrian, Vahakn N. and Taner Akçam. 2011. Judgment at Istanbul: The Armenian Genocide Trials. New York: Berghahn Books.

Dadrian, Vahakn N. 1975. “A Typology of Genocide." International Review of Modern Sociology. 5:2.

Dadrian, Vahakn N. 2004. "Patterns of twentieth century genocides: the Armenian, Jewish and Rwandan cases." Journal of Genocide Research 6 (4): 487-522.

Dallaire, Roméo. 1994. "Outgoing Code Cable: Request for Protection for Informant," United Nations Assistance Mission for Rwanda. January 11, 1994.

Dallaire, Roméo. 2005. Shake Hands with the Devil: The Failure of Humanity in Rwanda. New York: Carroll and Graf Publishers.

Daniel J. Goldhagen. 1996. Hitler's Willing Executioners: Ordinary Germans and the Final Solution. New York: Knopf.

Davin, Delia. 2013. Mao: A Very Short Introduction. Oxford: Oxford University Press. 
Dawidowicz, Lucy. 1975. The War against the Jews, 1933-1945. New York: Holt, Rinehart and Winston.

de Swaan, Abram. 2001. "Dyscivilization, Mass Extermination and the State," Theory, Culture \& Society. 18 (2-3).

de Swaan, Abram. The Killing Compartments: The Mentality of Mass Murder. New Haven and London: Yale University Press.

de Waal, Alex. 2007. "Darfur's Elusive Peace," in Alex de Waal, ed., War in Darfur and the Search for Peace. Cambridge, MA: Global Equity Initiative, Harvard University, and Justice Africa.

De Witte, Ludo. 2017. "The suppression of the Congo rebellions and the rise of Mobutu, 1963-5." The International History Review. 39 (1).

Dean, Martin. 2000. Collaboration in the Holocaust: Crimes of the Local Police in Belorussia and Ukraine. New York: St. Martin's Press.

Des Forges, Allison (1999) Leave None to Tell the Story: Genocide in Rwanda (New York: Human Rights Watch).

Desforges, Alison, Leave None to Tell the Story: Genocide in Rwanda (Human Rights Watch, March 1999).

Diamond, Jared, The Third Chimpanzee (New York: Harper Perennial, 1992).

Dieckmann, Christoph, Kooperation und Verbrechen: Fromen der "Kollaboration" im östlichen Europa, 1939-1945 (Göttingen: Wallstein, 2003).

Domarus, Max, edited by Patrick Romane, The Essential Hitler: Speeches and Commentary (Wauconda, IL: Bolchazy-Carducci Publishers, Inc., 2007).

Drost, Pieter, The Crime of State: Penal Protection for Fundamental Freedoms of Persons and Peoples (A.W. Sythoff, 1959).

Dumitru, Diana, The State, Antisemitism, and Collaboration in the Holocaust: The Borderlands of Romania and the Soviet Union (New York: United States Holocaust Memorial Museum and Cambridge University Press, 2016).

Eckhardt, A. L. and A. R. Eckhardt, "The Holocaust and the Enigma of Uniqueness. A Philosophical Effort at Practical Clarification," in I. G. Shur, F. H. Littell and E. Wolfgang, eds, Reflections on the Holocaust: Historical, Philosophical, and Educational 
Dimensions, Vol 450 of The Annals of the American Academy of Political and Social Science, July 1980, pp 165-178.

Elbedour, Salman, Ahmad M. Baker, and William R. Charlesworth, "The impact of political violence on moral reasoning in children," Child Abuse \& Neglect 21:11 (1997).

Elden, Stuart, "National Socialism and the Politics of Calculation," Social \& Cultural Geography Vol. 7, No. 5 (October 2006).

Elder, Tanya, "What you see before your eyes: documenting Raphael Lemkin's life by exploring his archival Papers, 1900-1959," Journal of Genocide Research 7:4 (2005) 469-499.

Ellman, Michael, "Stalin and the Soviet Famine of 1932-133 Revisited" Europe-Asia Studies 59:4 (June 2007), pp. 663-693 and he attributes this number to S.V. Kul'chits'kii, Golod 1932-1933 gg. v. Ukraine kak genotsid (Kyiv: Institute of Ukrainian History and Ukranian Academy of Sciences, 2005).

Epstein, Hele, "Sources That Link RPF to Rwanda Plane Plot," September 20, 2017, The Guardian. URL: https://www.theguardian.com/world/2017/sep/20/sources-that-link-rpfto-rwanda-plane-plot.

Etcheson, Craig, The Rise and Demise of Democratic Kampuchea (Boulder, CO: Westview Press, 1984).

Etcheson, Craig. After the Killing Fields: Lessons from the Cambodian Genocide, Greenwood (2005).

Evans, Richard J., The Coming of the Third Reich (New York: The Penguin Press, 2004).

Excerpt from Otto von Bismarck's "Blood and Iron" speech at a meeting of the Prussian Parliament on September 30, 1862. Translated by Jeremiah Riemer from source: Otto von Bismarck, Reden 1847-1869 [Speeches, 1847-1869], ed., Wilhelm Schüßler, vol. 10, Bismarck: Die gesammelten Werke [Bismarck: Collected Works], ed. Hermann von Petersdorff. Berlin: Otto Stolberg, 1924-35, pp. 139-40. URL:

http://germanhistorydocs.ghidc.org/sub_document.cfm?document_id=250\&language=en glish.

Fackenheim, Emil L. "The Holocaust and Philosophy," The Journal of Philosophy Vol. 82, No. 10 (October 1985), p. 507-508.

Fein, Helen. 1979. Accounting for Genocide: National Responses and Jewish Victimization during the Holocaust. New York: Free Press. 
Fein, Helen. 1984. "Scenarios of Genocide: Models of Genocide and Critical Responses." In Toward the Understanding and Prevention of Genocide, ed. Israel W. Charny. Boulder, CO: Westview Press.

Fein, Helen. 1984. "Scenarios of Genocide: Models of Genocide and Critical Responses." In Toward the Understanding and Prevention of Genocide, ed. Israel W. Charny. Boulder, CO: Westview Press.

Finkel, Evgeny and Scott Straus, "Macro, Meso, and Micro Research on Genocide: Gains, Shortcomings, and Future Areas of Inquiry," Genocide Studies and Prevention 7:1 (Spring 2012).

Finkelstein, Norman, “The Holocaust industry" Index on Censorship 29:2 (2000) 120130.

Fitzpatrick, Sheila, "New Perspectives on Stalinism" The Russian Review 45:4 (October 1986).

Fitzpatrick, Sheila, Stalin's Peasants: Resistance and Survival in the Russian Village after Collectivization (New York: Oxford University Press, 1994).

Fleet, Josh, "History and Meaning of the Word 'Holocaust': Are We Still Comfortable with This Term?" The Huffington Post, March 28, 2012, http://www.huffingtonpost.com/2012/01/27/the-word-holocaust-history-andmeaning_n_1229043.html.

Fletcher, Jonathan, Violence and Organization: An Introduction to the Work of Norbert Elias (Cambridge: Polity Press, 1997).

Flint, Julie and Alex de Waal, Darfur: A Short History of a Long War (London: Zed Books, 2006).

Flint, Julie, "Darfur's Armed Movements," in Alex de Waal, ed., War in Darfur and the Search for Peace (Cambridge, MA: Global Equity Initiative, Harvard University, and Justice Africa, 2007).

Freeman, Michael, "The Theory and Prevention of Genocide," Holocaust and Genocide Studies Vol. 6. (1991).

Friedlander, Henry, "Step by step: the expansion of murder, 1939-1941," in Omer Bartov eds., The Holocaust: Origins, Implementation, Aftermath (London and New York: Routledge, 2000), p. 63-76.

Friedlander, Henry, The Origins of Nazi Genocide: From Euthanasian to the Final Solution (Chapel Hill and London: The University of North Carolina Press, 1995). 
Friedländer, Saul, Pius XII and the Third Reich: A Documentation (Knopf, 1966).

Friedländer, Saul, The Years of Extermination: Nazi Germany and the Jews, 1939-1945 (New York: Harper Collins Publishers, 2007).

Friedman, Saul S., A History of the Holocaust (London and Portland, OR: Vallentine Mitchell, 2004).

From the Editor: the eagles and the worms: on the future agenda of genocides studies," Journal of Genocide Research 3:3 (2001).

Fujii, Lee Ann, Killing Neighbors: Webs of Violence in Rwanda (Ithaca, NY: Cornell University Press, 2009).

Gaunt, David, Paul A. Levine, and Laura Palosuo, Collaboration and Resistance during the Holocaust: Belarus, Estonia, Latvia, Lithuania (New York: Peter Lang, 2004).

George, Alexander L. and Andrew Bennett, Case Studies and Theory Development in the Social Sciences (Cambridge and London: MIT Press, 2004).

Georgy, Michael and Maher Chmaytelli, "From 'Caliph' to Fugutive: IS Leader Baghdadi's New Life on the Run,” Reuters, June 14, 2017, Accessed on August 8, 2018.

Gerlach, Christian. 2010. Extremely Violent Societies: Mass Violence in the TwentiethCentury World. Cambridge: Cambridge University Press.

Gerlach, Christian. 2010. Extremely Violent Societies: Mass Violence in the TwentiethCentury World. Cambridge: Cambridge University Press.

Germani, Hans, White Soldiers in Black Africa: Related from His Own Experiences; Jerry Puren's, Mercenary Commander.

Getty, J. Arch and Oleg V. Naumov, trans. by Benjamin Sher, The Road to Terror: Stalin and the Self-Destruction of the Bolsheviks, 1932-1939 (New Haven and London: Yale University Press, 1999).

Gibbs, David N.. 2009. First Do No Harm: Humanitarian Intervention and the Destruction of Yugoslavia. Nashville: Vanderbilt University Press.

Glanville, Luke, "Is “genocide" still a powerful word?" Journal of Genocide Studies 11:4 (2009). 
Gleijeses, Piero, "'Flee! The White Giants Are Coming!': The United States, the Mercenaries, and the Congo, 1964-65" Diplomatic History Vol. 18, No. 2 (2007), pp. 207-237.

Goldenberg, Myrna and Amy H. Shapiro, Different Horrors, Same Hell: Gender and the Holocaust (Seattle, WA: University of Washington Press, 2013).

Goldhagen, Daniel J., Christopher R. Browning, Leon Wieseltier, and Michael Berenbaum, "The "Willing Executioners" / "Ordinary Men" Debate," Selections from the Symposium, United State Holocaust Memorial Museum, April 8, 1996.

Goldsmith, Katherine, "The Issue of Intent in the Genocide Convention and Its Effect on the Prevention and Punishment of the Crime of Genocide: Toward a Knowledge-Based Approach," Genocide Studies and Prevention 5:3 (Winter 2010).

Gorove, Stephen, "The Problem of "Mental Harm" in the Genocide Convention," Washington University Law Quarterly Vol. 1951, Issue 2 (1951) 174-187.

Gould, Harry D. , "Categorical obligation in international law" International Theory Vol 3., No. 2, (2011).

Gould, Harry D. , The Legacy of Punishment in International Law (Palgrave Macmillan, 2010).

Gourevitch, Philip, We wish to inform you that tomorrow we will be killed with our families: Stories from Rwanda (New York: Farrar, Straus \& Giroux, 1998).

Government Accountability Office, "Darfur Crisis: Death Estimates Demonstrate Severity of Crisis, but Their Accuracy and Credibility Could Be Enhanced" (Washington, DC: Government Accountability Office, 2006).

Grau, Günter, "Final Solution of the Homosexual Question? The Antihomosexual Policies of the Nazis and the Social Consequences for Homosexual Men," in Michael Berenbaum and Abraham J. Peck eds., The Holocaust and History: The Known, the Unknown, the Disputed, and the Reexamined (Washington, D.C., Bloomington and Indianapolis: United States Holocaust Memorial Museum and Indiana University Press, 1998).

Grau, Günter, eds., Hidden Holocaust? Gay and Lesbian Persecution in Germany 193345 (Chicago and London: Fitzroy Dearborn, 1995).

Graziosi, Andrea, "The Soviet 1931-1933 Famines and the Ukrainian Holodomor: Is a New Interpretation Possible, and What Would Its Consequences Be?" Harvard Ukrainian Studies 27:1/4 (2004-2005). 
Griech-Polelle, Beth A., Anti-Semitism and the Holocaust: Language, Rhetoric and the Traditions of Hatred (London: Bloomsbury, 2017).

Gross, Jan T. , Neighbors: The Destruction of the Jewish Community in Jedwabne, Poland (Princeton, NJ: Princeton University Press, 2001).

Gruner, Wolf, Jewish Forced Labor Under the Nazis: Economic Needs and Racial Aims, 1938-1944, trans. Kathleen M. Dell'orto (New York: Cambridge University Press, 2006).

Guatemala: Memory of Silence, Report of the Commission for Historical Clarification, United Nations, (1997).

Guha-Sapir, Debarati and Olivier Degomme, "Counting the Deaths in Darfur: Estimating mortality from multiple survey data," Households in Conflict Network, The Institute of Development Studies (Falmer, England: University of Sussex, 2006).

Haass, Richard, A World in Disarray: American Foreign Policy and the Crisis of the Old Order (New York: Penguin Books, 2017).

Hagan, John and Wenona Rymond-Richmond, "The Collective Dynamics of Racial Dehumanization and Genocidal Victimization in Darfur, American Sociological Review 73 (2008), p. 875-902.

Hagenloh, Paul, Stalin's Police: Public Order and Mass Repression in the USSR, 19261941 (Washington, DC and Baltimore: Woodrow Wilson Center Press and The Johns Hopkins University Press, 2009).

Haggar, Ali, "The Origins and Organization of the Janjawiid in Darfur," in Alex de Waal, ed., War in Darfur and the Search for Peace (Cambridge, MA: Global Equity Initiative, Harvard University, and Justice Africa, 2007).

Hansen, Randall, Fire and Fury: The Allied Bombing of Germany, 1942-1945 (New York: Nal Caliber, New American Library, 2008).

Harff, Barbara and Ted Robert Gurr, "Systematic Early Warning of Humanitarian Emergencies." Journal of Peace Research Vol. 35, No. 5, (1998).

Harff, Barbara and Ted Robert Gurr, "Toward Empirical Theory of Genocides and Politicides: Identification and Measurement of Cases Since 1945" International Studies Quarterly 32:3 (September 1988).

Harff, Barbara and Ted Robert Gurr, "Toward Empirical Theory of Genocides and Politicides: Identification and Measurement of Cases Since 1945, International Studies Quarterly, Vol. 32, No. 3, (1988) 364-365. 
Harff, Barbara, "No Lessons Learned from the Holocaust? Assessing Risks of Genocide and Political Mass Murder since 1955," American Political Science Review Vol. 97, No. 1 (2003).

Harff, Barbara, Genocide and Human Rights: International Legal and Political Issues (Denver, CO: Monograph Series in World Affairs, Graduate School of International Studies, University of Denver, 1984) Vol. 20, Book 3.

Harff, Barbara. 2003. "No Lessons Learned from the Holocaust? Assessing Risks of Genocide and Political Mass Murder since 1955." American Political Science Review 97(1), pp. 57-73.

Hatzfeld, Jean, Machete Season: The Killers in Rwanda Speak (New York: Farrar, Straus and Giroux, 2005).

Hausner, Gideon, WPBH video "The Hunter and the Hunted" (PBS 1981), quoted in Stephen C. Feinstein, ed., Absence/Presence: Critical Essays on the Artistic Memory of the Holocaust (Syracuse, NY: Syracuse University Press, 2005).

Heinsohn, Gunnar, "What makes the Holocaust a uniquely unique genocide? Journal of Genocide Studies 2:3 (2000) 411-430.

Heitmeyer, Wilhelm and John Hagan, eds., International Handbook of Violence Research (Springer-Science+Business Media, B.V., 2003).

Hendrix, Steve, "Poland wants to outlaw blaming Poles for Nazi atrocities. But what about the Jedwabne massacre?" The Washington Post, February 6, 2018, accessed on April 12, 2018. URL:

https://www.washingtonpost.com/news/retropolis/wp/2018/02/06/poland-wants-tooutlaw-blaming-poles-for-nazi-atrocities-but-what-about-the-jedwabnemassacre/?noredirect $=$ on\&utm_term $=. \mathrm{a} 8 \mathrm{fc} 946 \mathrm{~b} 203 \mathrm{c}$.

Herf, Jeffrey, "The 'Jewish War': Goebbels and the Antisemitic Campaigns of the Nazi Propaganda Ministry," Holocaust and Genocide Studies Vol. 19, No. 1 (Spring 2015), p. 51-80.

Herf, Jeffrey, The Jewish Enemy: Nazi Propaganda During World War II and the Holocaust (Cambridge, MA and London: The Belknap Press of Harvard University Press, 2006).

Herman, Judith, Trauma and Recovery: The aftermath of violence - from domestic abuse to political terror (New York: Basic Books, 1997). 
Heuveline, Patrick. "Between One and Three Million': Towards the Demographic Reconstruction of a Decade of Cambodian History (1970-79)" Population

Studies (Taylor \& Francis, 1998) pp. 49-65.

Hilberg, Raul, Perpetrators, Victims, Bystanders: The Jewish Catastrophe 1933-1945 (New York: Harper-Collins, 1992).

Hilberg, Raul, The Destruction of the European Hews, revised edition, 3 volumes (New York: Holmes \& Meier, 1985).

Hilberg, Raul, The Destruction of the European Jews (Chicago: Quadrangle, 1967).

Hintjens, Helen M. "Explaining the 1994 genocide in Rwanda," The Journal of Modern Africa Studies 37:2 (1999).

Hinton, Alexander Laban, Thomas La Pointe, and Douglas Irvin-Erickson, eds. 2014. Hidden Genocides: Power, Knowledge, Memory. New Brunswick, NJ: Rutgers University Press.

His-Sheng, Ch'i, Warlord Politics in China 1916-1928 (Stanford, CA: Stanford University Press, 1976).

Hitler, Adolf, Mein Kampf, trans. by Ralph Manheim (New York: Houghton Mifflin Company, [1925] 1971).

Hoare, Michael, The Road to Kalamata: A Congo Mercenary's Personal Memoir and Congo Mercenary. 2014.

Holquist, Peter, "“Conduct Merciless Mass Terror': Decossackization on the Don, 1919” Cahiers du Monde russe 38 (1-2) 1997: 127-162.

Horowitz, Irving Louis, Genocide: State Power and Mass Murder (New Brunswick, NJ: Transaction Books, 1976).

Hovannisan, Richard G., "Etiology and Sequence of the Armenian Genocide," in George J. Andreopoulos, eds. Genocide: Conceptual and Historical Dimensions (Philadelphia, University of Pennsylvania Press, 1994) 111-140.

Human Rights Watch (HRW), Abducted and Abused: Renewed Conflict in Northern Uganda, Report Vol. 15, No. 12 (A), July 2003, available online at http://www.hrw.org/reports/2003/uganda0703 (visited 5 February 2004).

Huttenbach, Henry, "Locating the Holocaust on the genocide spectrum" Holocaust and Genocide Studies 3:3 (1988) 289-304. 
International Criminal Court, "The Prosecutor v. Joseph Kony and Vincent Otti: Case Information Sheet” Updated April 2018, ICC-PIDS-CIS-UGA-001-006/18_Eng.

International Criminal Court, "The Prosecutor v. Omar Hassan Ahmad Al Bashir: Case Information Sheet,” Updated April 2018, ICC-PIDS-CIS-SUD-02-006/19_Eng.

International Criminal Tribunal for Rwanda, The Prosecutor versus Jean-Paul Akayesu, Case No. ICTR-96-4-T, (1998).

International Criminal Tribunal for the Former Yugoslavia, The Prosecutor v. Goran Jelisi. Case No. IT-95-10-T, (1999).

Jackson, Karl D., "The Ideology of Total Revolution,” in Karl D. Jackson, ed., Cambodia: 1975-1978: Rendezvous with Death (Princeton: Princeton University Press, 1989), p. 39-49.

Jonassohn, Kurt and Karin Solveig Björnson, Genocide and Gross Human Rights Violations: In Comparative Perspective (New Brunswick, NJ and London: Transaction Publishers, Inc., 1998).

Jones, Adam "Diffusing Genocide Studies, Defusing Genocides," Genocide Studies and Prevention 6:3 (Winter 2011).

Jones, Adam, "Genocide as Political Violence" in Marie Breen-Smyth, ed., The Ashgate Research Companion to Political Violence (London and New York: Routledge, 2012).

Jones, Adam, Genocide: A Comprehensive Introduction, Second Edition. (New York: Routledge, Taylor \& Francis Group, 2011).

Jones, B. (2001) Peacemaking in Rwanda: The Dynamics of Failure (Boulder: Lynne Rienner).

Julicher, Peter, "Enemies of the People" Under the Soviets: A History of Repression and Its Consequences (Jefferson, NC: McFarland \& Company, Inc., 2015).

Karazsia, Zachary A., "Developing Hearts and Land: A Case Study of Reconciliation, Governance, and Development in Rwanda," in Louis A. Picard, Terry F. Buss, Taylor B. Seybolt, and Macrina C. Lelei eds., Sustainable Development and Human Security in Africa: Governance as the Missing Link (Boca Raton, FL: CRC Press, 2015), pp. 233248.

Karazsia, Zachary A., "Peace Inc? The Role of Contractors in International Peace Operations" Ford Institute for Human Security, University of Pittsburgh, April 11, 2012. 
Katz, Steven, The Holocaust in Historical Context: The Holocaust and Mass Death before the Modern Age, Volume I (New York: Oxford University Press, 1994).

Kelman, Herbert G., "Violence without Moral Restraint: Reflections on the Dehumanization of Victims and Victimizers," Journal of Social Issues Vol. 29, No. 4 (1973), p. 25-61.

Kenez, Peter, A History of the Soviet Union from the Beginning to the End (Cambridge: Cambridge University Press, 1999).

Kershaw, Ian and Moshe Lewin eds., Stalinism and Nazism: Dictatorships in Comparison (Cambridge: Cambridge University Press, 1997).

Kershaw, Ian and Moshe Lewin, eds, Stalinism and Nazism: Dictatorships in Comparison (Philadelphia: Cambridge University Press, 2012).

Kershaw, Ian, "Hitler and the Uniqueness of Nazism," Journal of Contemporary History Vol. 39, No. 2 (2004), p. 239-254.

Kessler, Gijs "The Passport System and State Control over Population Flows in the Soviet Union, 1932-1940," Cahiers du Monde Russe 42:2-4 (2001), 477-504.

Kiernan, Ben, Blood and Soil: A World History of Genocide and Extermination from Sparta to Darfur (New Haven and London: Yale University Press, 2009).

Kiernan, Ben, How Pol Pot Came to Power: Colonialism, Nationalism, and Communism in Cambodia, 1930-1975, $2^{\text {nd }}$ Edition (New Haven and London: Yale University Press, 2004).

Kiernan, Ben, The Pol Pot Regime: Race, Power, and Genocide under the Khmer Rouge, 1975-79 (New Haven and London: Yale University Press, 2008).

Kifner, John, “Armenian Genocide of 1915: An Overview," The New York Times (May 31, 2013).

Kimonyo, Jean-Paul, Rwanda's Popular Genocide: A Perfect Storm, trans. by Wandia Njoya (Boulder, CO and London: Lynne Reiner Publishers, 2016).

Kimura, Akio, "Genocide and the modern mind: intention and structure," Journal of Genocide Studies 5:3 (2003).

Kissi, Edward, Revolution and Genocide in Ethiopia and Cambodia (Lanham: Lexington Books, 2006). 
Kolakowski, Leszek, "Marxist Roots of Stalinism” in Robert C. Tucker eds., Stalinism: Essays in Historical Interpretation (New York: W.W. Norton and Company, Inc., 1977).

Korff, Gottfried and Larry Peterson, "From Brotherly Handshake to Militant Clenched Fist: On Political Metaphors for the Worker's Hand," International Labor and WorkingClass History No. 42 (1992).

Kort, Michael, The Soviet Colossus: History and Aftermath, $6^{\text {th }}$ Edition (Armonk, NY: M.E. Sharpe, 2006).

Krain, Matthew, "State-Sponsored Mass Murder" Journal of Conflict Resolution Vol. 41, No. 3 (1997), p. 331-360.

Kreindler, Stuart M., "History's Accounting: Liability Issues Surrounding German Companies for the Use of Slave Labor by Their Corporate Forefathers," Penn State International Law Review 18:2 (2000).

Kuper, Leo, "Types of genocide and mass murder," in Israel Charny, ed., Toward the Understanding and Prevention of Genocide: Proceedings of the International Conference on the Holocaust and Genocide (Boulder: Westview Press, 1984), pp 32-47.

Kuper, Leo, Genocide: Its Political Use in the Twentieth Century (New Haven, CT: 1981).

Kuper, Leo, Genocide: Its Political Use in the Twentieth Century (New Haven, CT: 1981).

Kuper, Leo, The Pity of It All: Polarisation of Racial and Ethnic Relations (Minneapolis: University of Minnesota Press, 1977).

Kwami Anyidoho, Henry, Guns over Kigali: The Rwandese Civil War - 1994 (A Personal Account) (Accra New Town, Ghana: Fountain Publishers, 1998).

Labott, Elise and Tal Kopan. March 18, 2016. "John Kerry: ISIS responsible for genocide,” CNN. URL: http://www.cnn.com/2016/03/17/politics/us-iraq-syria-genocide/.

Lang, Berel, "Response to Paul Boghossian, 'The concept of genocide,' Journal of Genocide Research 12:1-2 (2010).

Lautman, Rüdiger, "The Pink Triangle: Homosexuals as "Enemies of the State" in Michael Berenbaum and Abraham J. Peck eds., The Holocaust and History: The Known, the Unknown, the Disputed, and the Reexamined (Washington, D.C., Bloomington and Indianapolis: United States Holocaust Memorial Museum and Indiana University Press, 1998). 
Lemarchand, René "Disconnecting the threads: Rwanda and the Holocaust reconsidered," Journal of Genocide Research Vol. 4, No. 4 (2002).

Lemarchand, René, Rwanda and Burundi (London: Pall Mall Press, 1970).

Lemkin, Raphael, "Totally unofficial," manuscript, undated, New York Public Library, Manuscript and Archives Division, The Raphael Lemkin Papers, Box 2: Bio- and Autobiographical Sketches of Lemkin.

Lemkin, Raphael, Axis Rule in Occupied Europe: Laws of Occupation, Analysis of Government, Proposals for Redress (Washington, DC: Carnegie Endowment for International Peace, Division of International Law, 1944).

Leu-wiesel, Rachel and Marianne Amir, "Holocaust Child Survivors and Child Sexual Abuse," Journal of Child Sexual Abuse Vol. 14, No. 2 (2005).

Levene, Mark, "Creating a Modern 'Zone of Genocide': The Impact of Nation- and State-Formation on Eastern Anatolia, 1878-1923," Holocaust and Genocide Studies 12:3 (1998): 393-433.

Lieberman, Benjamin, "Ethnic Cleansing versus Genocide?" in Donald Bloxham and A. Dirk Moses, eds., The Oxford Handbook of Genocide Studies (Oxford and New York: Oxford University Press, 2010).

Lifton, Robert Jay and Erik Markusen. 1991. The Genocidal Mentality: Nazi Holocaust and Nuclear Threat. Basic Books.

Lippman, Matthew , "The Nazi Doctors Trial and the International Prohibition on Medical Involvement in Torture," Loyola of Los Angeles International and Comparative Law Review 2:1 (1993) 395-441.

Lippman, Matthew, "A road map to the 1948 Convention on the Prevention and Punishment of the Crime Genocide" Journal of Genocide Studies 4:2 (2002).

Locard, Henri, "State Violence in Democratic Kampuchea (1975-1979) and Retribution (1979-2004)" European Review of History 12:1 (March 2005).

Longman, Timothy, "Church Politics and the Genocide in Rwanda," Journal of Religion in Africa Vol. 31, Iss. 2 (2001).

Longman, Timothy, "Identity Cards, Ethnic Self-Perception, and Genocide in Rwanda," in Jane Caplan and John Torpey, eds., Documenting Individual Identity: The Development of State Practices in the Modern World (Princeton and Oxford: Princeton University Press, 2001). 
Longman, Timothy, Christianity and Genocide in Rwanda (Cambridge: Cambridge University Press, 2010).

Louis, W.M. Roger, Ruanda-Urundu: 1884-1919 (Oxford: Clarendon Press, 1963).

Lower, Wendy, Nazi Empire-Building and the Holocaust in Ukraine (Chapel Hill: University of North Carolina Press, 2004).

Lutz, Ellen L. and Caitlin Reiger, ed., Prosecuting Heads of State (New York: Cambridge University Press, 2009).

Lynch, Michael, The Chinese Civil War 1945-49 (Oxford: Osprey Publishing Ltd, 2010).

Madley, Benjamin, "From Africa to Auschwitz: How German South West Africa Incubated Ideas and Methods Adopted and Developed by the Nazis in Eastern Europe" European History Quarterly 35:3 (2005).

Malia, Martin, The Soviet Tragedy: A History of Socialism in Russia, 1917-1991 (New York: Free Press, 1994).

Mamdani, Mahmood, The Politics of Naming: Genocide, Civil War, Insurgency (London: London Review of Books, 2007).

Mamdani, Mahmood, When Victims Become Killers: Colonialism, Nativism, and the Genocide in Rwanda (Princeton, NJ: Princeton University Press, 2001).

Mann, Michael. 2005. The Dark Side of Democracy: Explaining Ethnic Cleansing. Cambridge: Cambridge University Press.

Mao Tse-Tung, On Protracted War (Peking: Foreign Languages Press, 1967).

Margolin, Jean-Louis quoting Marek Sliwinski, Le genocide Khmer rouge: Une analyze démographique (Paris: L'Harmattan, 1995).

Matthews, Mervyn, The Passport Society: Controlling Movement in Russia and the USSR (Boulder: Westview Press, 1993).

May, Larry, Genocide: A Normative Account (New York: Cambridge University Press, 2010).

McAdam, Doug, Sidney Tarrow, and Charles Tilly. 2001. Dynamics of Contention. Cambridge: Cambridge University Press.

McCants, William, The ISIS Apocalypse: The History, Strategy, and Doomsday Vision of the Islamic State (New York: St. Martin's Press, 2015). 
McCullum, Hugh, The Angels Have Left Us: The Rwanda Tragedy and the Churches (Geneva: WCC Publications, 1995).

McDoom, Omar, "Rwanda's Ordinary Killers: Interpreting Popular Participation in the Rwandan Genocide," Crisis States Research Centre Working Papers Series, 1, 77 (London: Crisis States Research Centre, London School of Economics and Political Science, 2005).

Melson, Robert F., Revolution and Genocide: On the Origins of the Armenian Genocide and the Holocaust (Chicago and London: The University of Chicago Press, 1992).

Melson, Robert, 'Modern genocide in Rwanda: ideology, revolution, war, and mass murder in an African state', in Robert Gellately and Ben Kiernan (eds), The Specter of Genocide: Mass Murder in Historical Perspective (Cambridge: Cambridge University Press 2003).

Melson, Robert, Revolution and Genocide: On the Origins of the Armenian Genocide and the Holocaust (University of Chicago Press, 1992).

Melvern, Linda R., A People Betrayed: The role of the West in Rwanda's genocide (London and New York: Zed Books, 2000).

Melvin, Jess, The Army and the Indonesian Genocide: Mechanics of Mass Murder (London and New York: Routledge, 2018).

Mennecke, Martin, "What's in a Name? Reflections on Using, Not Using, and Overusing the "G Word," Genocide Studies and Prevention 2:1 (Spring 2007).

Mennell, Stephen, "Norbert Elias 91897-1990)," Norbert Elias Foundation. Accessed on February 5, 2018. URL: http://www.norberteliasfoundation.nl/elias/index.php.

Meyler, Bernadette, "Economic Emergency and the Rule of Law," DePaul Law Review Vol. 56 (2007).

Midlarsky, Manus I., "The Demographics of Genocide: Refugees and Territorial Loss in the Mass Murder of European Jewry," Journal of Peace Research 42 (Jul 2005): 375-91.

Midlarsky, Manus I., The Killing Trap: Genocide in the Twentieth Century (Cambridge: Cambridge University Press, 2005).

Moller, Arlen C. and Edward L. Deci, "Interpersonal control, dehumanization, and violence: A self-determination theory perspective," Group Processes \& Intergroup Relations Vol. 13, Iss. 1 (2009), p. 41-53. 
Moses, A Dirk, "Revisiting a Founding Assumption of Genocide Studies," Genocide Studies and Prevention 6:3 (Winter 2011) 288.

Moses, A. Dirk, "From the Editor: the eagles and the worms: on the future agenda of genocides studies," Journal of Genocide Research 3:3 (2001) 345-346.

Moses, A. Dirk, "Raphael Lemkin, Culture, and the Concept of Genocide" in Donald Bloxham and A. Dirk Moses, eds. The Oxford Handbook of Genocide Studies (New York: Oxford University Press, 2010).

Muhumuza, Rodney, "British official: South Sudan violence is tribal 'genocide,"' Associated Press. Accessed on April 21, 2017, URL:

http://www.hawaiinewsnow.com/story/35139385/british-official-south-sudan-violenceis-tribal-genocide.

Mullins, Christopher W. “'We Are Going to Rape You and Taste Tutsi Women': Rape During the 1994 Rwandan Genocide" The British Journal of Criminology Vol 49. (2009).

Naimark, Norman M. 2001. Fires of Hatred: Ethnic Cleansing in Twentieth Century Europe. Harvard University Press.

Napoleoni, Loretta, ISIS: The Terror Nation (New York: Seven Stories Press, 2017).

Nettl, J.P., The Soviet Achievement (New York: Harcourt Brace \& Co., 1967).

Newman, Leonard S. and Ralph Erber, eds. Understanding Genocide: The Social Psychology of the Holocaust (Oxford: Oxford University Press, 2002).

Ngor, Haing, Survival in the Killing Fields (London: Macmillan Publishing Company, 1987).

Norton-Taylor, Richard, "Up to 30,000 Foreign Fighters Have Gone to Syria and Iraq Since 2011 - Report” The Guardian, November 17, 2015.

Nowrojee, Binaifer, Shattered Lives: Sexual Violence During the Rwandan Genocide and Its Aftermath (New York: Human Rights Watch, 1996).

Nowrojee, Shattered Lives cites Catherine Bonnet, "Le viol des femmes survivantes du genocide du Rwanda," in Rwanda: Un genocide du XXe siècle, (Raymond Verdier, Emmanuel Decaux, Jean-Pierre Chrétien eds. (Paris: Editions L'Harmattan, 1995).

Nussebaum Soumerai, Eve and Carol D. Schultz, Daily Life During the Holocaust (Westport, CT and London: Greenwood Press, 1998). 
Office of Population Research, "Current Estimates of the Size and Distribution of China's Population," Population Index Vol. 14, No. 1 (January 1948).

Olson, Richard, personal correspondence with author, November 8, 2017.

OMICS International, Accessed April 10, 2017, URL:

http://research.omicsgroup.org/index.php/

Passemiers, Lazlo Patrick Christian "South Africa and the 'Congo Crisis', 1960-1965" (doctoral dissertation, The University of the Free State, 2016).

Paust, Jordan J., M. Cherif Bassiouni, Michael Scharf, Leila Sadat, Jimmy Gurulé, and Bruce Zagaris, Human Rights Module: On Crimes Against Humanity, Genocide, Other Crimes Against Human Rights, and War Crimes: Third Edition (Durham, NC: Carolina Academic Press, 2014).

Perelman, Chaim, “The Rational and the Reasonable” Philosophic Exchange 10:1 (1979).

Pham, Phoung, Patrick Vinck, and Eric Stover, "Abducted: The Lord's Resistance Army and Force Conscription in Northern Uganda" Berkeley-Tulane Initiative on Vulnerable Populations (Human Rights Center, University of California, Berkeley, Payson Center for International Development, Tulane University, June 2007).

Piao, Lin, Long Live the Victory of People's War! (Peking: Foreign Languages Press, 1965).

Pipes, Richard, eds., The Unknown Lenin: From the Secret Archive, trans. of Russian documents by Catherine A. Fitzpatrick (New York: Yale University Press, 1998).

Poliakov, Léon, Harvest of Hate: The Nazi Program for the Destruction of Jews in Europe (New York: History Library, 1956).

Ponchaud, François, Cambodia Year Zero, trans. by Nancy Amphoux (New York: Holt, Rinehart and Winston, 1977).

Porter, Jack Nusan, The Genocidal Mind: Sociological and Sexual Perspectives (University Press of America, 1982).

Powell, Christopher and Amarnath Amarasingam. 2017. "Atrocity and Proto-Genocide in Sri Lanka" in Scott W. Murray, ed., Understanding Atrocities: Remembering, Representing, and Teaching Genocide. Calgary, Alberta, Canada: University of Calgary Press.

Powell, Christopher, "What do genocides kill? A relational conception of genocide," Journal of Genocide Research 9:4 (2007) 527-547. 
Priestland, David, Stalinism and the Politics of Mobilization: Ideas, Power, and Terror in Inter-war Russia (Oxford: Oxford University Press, 2007).

Prunier, Gérard, The Rwanda Crisis: History of a Genocide (New York: Columbia University Press, 1995).

Puren, Jerry and Brian Pottinger, Mercenary Commander: Col Jerry Puren as Told by Brian Pottinger (Alberton: Galago, 1986).

Reed, Wm. Cyrus, "Exile, Reform, and the Rise of the Rwandan Patriotic Front," Journal of Modern African Studies 34, 3 (1996).

Rees, E.A., eds., Centre-Local Relations in the Stalinist State, 1928-1941 (New York: Palgrave Macmillan, 2002).

Rees, E.A., Iron Lazar: A Political Biography of Lazar Kaganovich (London: Anthem Press, 2013).

Reeves, Eric, "Stopping Genocide in Darfur: What Must Be Done", May 17, 2004. URL: http:sudanrevees.org.

Rhodes, Richard, Master of Death: The SS-Einsatzgruppen and the Invention of the Holocaust (New York: Vintage Books, 2003).

Ringelheim, Joan "Women and the Holocaust: A Reconstruction of Reserves," Signs Vol. 10, No. 4 (Summer 1985), p. 743-744.

Rome Statute of the International Criminal Court, Text of the Rome Statute circulated as document A/CONF.183/9 of 17 July 1998 and corrected by process-verbaux of 10 November 1998, 12 July 1999, 30 November 1999, 8 May 2000, 17 January 2001 and 16 January 2002. The Statute entered into force on 1 July 2002, Accessed April 16, 2017, p. 3.

Rosenbaum, Alan S. Is the Holocaust unique? Perspectives on Comparative Genocide (Boulder, CO: Westview Press Inc., 1996).

Rosenberg, Alan, "Was the Holocaust Unique? A Peculiar Question?" in Isidor Wallimann \& Michael N. Dobkowski, Genocide in the Modern Age: Etiology and Case Studies of Mass Death (New York: Greenwood Press, 1987) 145-161.

Rotzoll, Maike, Paul Richter, Petra Fuchs, Annette Hinz-wessels, Sascha Topp, and Gerrit Hohendorf, "The First National Socialist Extermination Crime: The T4 Program and Its Victims," International Journal of Mental Health Vol. 35, No. 3 (Fall 2006). 
Rummel, R.J., Lethal Politics: Soviet Genocide and Mass Murder since 1917 (New Brunswick: Transaction Publishers, 1990).

Rummel, Rudolph, 1998. Statistics on Democide: Genocide and Mass Murder since 1900. Wissenschaftliche Paperbacks.

Rummel. Rudolph J., 1994. Death by Government. New Brunswick, N.J.: Transactions Publishers.

Salmon, Wesley C., Logic (Englewood Cliffs: Prentice-Hall, 1963).

Sartori, Giovanni, "Concept Misformation in Comparative Politics," The American Political Science Review 64:4 (December 1970), 1033-1053.

Savon, Hervé, Du cannibalisme au genocide (Paris: Hachette, 1972). Summarized by Frank Chalk and Kurt Jonassohn, The History and Sociology of Genocide: Analysis and Case Studies (New Haven and London: Montreal Institute for Genocide Studies and Yale University Press, 1990).

Schaack, Beth Van, "The Crime of Political Genocide: Repairing the Genocide Convention's Blind Spot," The Yale Law Journal 106:7 (May 1997): 2259-2291.

Schabas, William A., "Definitional Traps and Misleading Titles," Genocide Studies and Prevention 4:2 (Summer 2009) 177-183.

Schabas, William A., Genocide in International Law (Cambridge: Cambridge University Press, 2000).

Schabas, William A., Genocide in International Law (Cambridge: Cambridge University Press, 2000).

Schabas, William, Introduction to the International Criminal Court, 2nd ed., (New York: Cambridge University Press, 2004).

Schaller, Dominik J. "From Lemkin to Clooney: The Development and State of Genocide Studies," Genocide Studies and Prevention 6:3 (Winter 2011) 245-256.

Scheffer, David, "Genocide and Atrocity Crimes" Genocide Studies and Prevention: An International Journal 1:3 (2006).

Scherrer, Christian P. "Towards a theory of modern genocide. Comparative genocide research: Definitions, criteria, typologies, cases, key elements, patterns and voids," Journal of Genocide Research 1:1 (1999) 13-23. 
Schurmann, Franz, Ideology and Organization in Communist China, Second Edition, Enlarged (Berkeley and Los Angeles, 1968).

Schwarz, Henry G. Liu Shao-Ch'I and "People's War": A Report on the Creation of Base Areas in 1938 (New York: Paragon Book Gallery, Ltd, 1969).

Schwarz, Liu Shao-Ch'I and “People's War”, p. 50; John W. Lewis, “The Study of Chinese Political Culture,” World Politics Vol. 18, No. 3 (April 1966).

Segesser, Daniel Marc and Myriam Gessler, "Raphael Lemkin and the international debate on the punishment of war crimes (1919-1948)," Journal of Genocide Research 7:4 (2005).

Sémelin, Jacques, "In consideration of massacres," Journal of Genocide Research 3:3 (2001) 377-389.

Semelin, Jacques, "Toward a vocabulary of massacre and genocide" Journal of Genocide Research 5:2 (2003).

Semelin, Jacques, Purify and Destroy: The Political Uses of Massacre and Genocide. Translated from the French by Cynthia Schoch, (New York: Columbia University Press, 2007).

Sereny, Gitta, “Spin Time for Hitler,” The Observer Review, April 21, 1996.

Seybolt, Taylor B. with Shena L. Cavallo, Stephen Coulthart, Zachary A. Karazsia, Aurora Matthews, and Farhod Yuldashev (2011) "Unpacking the Process of Mass Killing: Motives, Means, and Opportunities," presented by Dr. Taylor B. Seybolt, at the Annual Meeting of the American Political Science Association, Seattle, Washington, September 1-2, 2011.

Seybolt, Taylor B., Jay D. Aronson, and Baruch Fischoff, Counting Civilian Casualties (Oxford: Oxford University Press, 2013).

Shatz, Howard J. and Erin-Elizabeth Johnson, The Islamic State We Knew (Santa Monica, CA: Rand Corporation, 2015).

Shaw, Martin, War \& Genocide (Cambridge: Polity Press, 2003).

Shaw, Martin, What is Genocide? (Malden, MA: Polity Press, 2007).

Shearer, David R., "Elements Near and Alien: Passportization, Policing, and Identity in the Stalinist State, 1932-1952," Journal of Modern History 76:4 (2004), 835-881. 
Shelton, Dinah L., ed., Encyclopedia of Genocide and Crimes Against Humanity (New York: Thomson Gale, 2005).

Sherman, Howard J., The Soviet Economy (Boston: Little, Brown, 1969).

Sherry, Michael S., The Rise of American Air Power: The Creation of Armageddon (New Haven and London: Yale University Press, 1987).

Shevchenko, Vitaly, "Little Green Men" or "Russian Invaders"? BBC, March 11, 2014. URL: https://www.bbc.com/news/world-europe-26532154.

Short, Philip, Pol Pot: Anatomy of a Nightmare (New York: Henry Holt and Company, 2004).

Sly, Liz, "Al-Qaeda disavows any ties with radical Islamist ISIS group in Syria, Iraq" The Washington Post, February 3, 2014. URL:

https://www.washingtonpost.com/world/middle_east/al-qaeda-disavows-any-ties-withradical-islamist-isis-group-in-syria-iraq/2014/02/03/2c9afc3a-8cef-11e3-98abfe5228217bd1_story.html?noredirect=on\&utm_term=.6b053c02ac73.

Smith, Ivan, Mad Dog Killers: The Story of a Congo Mercenary (Helion and Company, 2012).

Smith, Roger, "Human destructiveness and politics: the twentieth century as an age of genocide," in Isidor Walliman and Michael Dobkowski, eds, Genocide and the Modern Age: Etiology and Case Studies of Mass Death (Westport: Greenwood Press, 1987), pp 23-27.

Snow, Edgar, Random Notes on Red China: 1936-1945 (Cambridge, MA: East Asian Research Center, Harvard University Press, 1968).

Snyder, Timothy, Black Earth: The Holocaust as History and Warning (London: The Bodley Head, 2015).

Snyder, Timothy, Sketches from a Secret War: A Polish Artist's Mission to Liberate Soviet Ukraine (New Haven: Yale University Press, 2005).

Snyder, Timothy, The Reconstruction of Nations: Poland, Ukraine, Belarus, 1569-1999 (New Haven: Yale University Press, 2003).

Sperling, Carrie, "Mother of Atrocities: Pauline Nyiramasuhuko's Role in the Rwandan Genocide" Fordham Urban Law Journal Vol. 33, No. 2 (2006),

Spitz, Vivien, Doctors from Hell: The Horrific Account of Nazi Experiments on Humans (Boulder, CO: Sentient Publications, 2005). 
Stang, Knut, Kollaboration und Massenmord: Die Litauische Hilfspolizei, das, Rollkommando Hamman und die Ermordung der litauischen Juden (Frankfurt am Mian: Peter Lang, 1996).

Stanton, Gregory, “The 8 Stages of Genocide," Genocide Watch: The International Campaign to End Genocide.

Staub, Ervin, The Roots of Evil: The Origins of Genocide and Other Group Violence (Cambridge, UK: Cambridge University Press, 1989).

Steidle, Brian and Gretchen Steidle Wallace, The Devil Came on Horseback: Bearing Witness to the Genocide in Darfur (New York: Public Affairs, 2007).

Stein, Stuart, "Geno- and other cides: a cautionary note on knowledge accumulation" Journal of Genocide Research 4:1 (2002).

Stein, Stuart. 2005. "Conceptions and Terms: Templates for the Analysis of Holocausts and Genocides," Journal of Genocide Research Vol 7., No. 2., p. 171-203.

Storey, Andy, "Structural Adjustment, State Power \& Genocide: The World Bank \& Rwanda," Review of African Political Economy Vol. 28, No. 89 (2001), p. 365-385.

Straus, Scott, "Contested meanings and conflicting imperatives: A conceptual analysis of genocide," Journal of Genocide Research 3:3 (2001).

Straus, Scott, "Contested meanings and conflicting imperatives: A conceptual analysis of genocide," Journal of Genocide Research 3:3 (2001) 349-375.

Straus, Scott, "How many perpetrators were there in the Rwandan genocide? An estimate" Journal of Genocide Research 6:1 (2004).

Straus, Scott, "Is a comparative theory of perpetrators possible?" in Timothy Williams and Susanne Buckley-Zistel, Perpetrators and Perpetration of Mass Violence: Action, Motivations and Dynamics (London and New York: Routledge, 2018).

Straus, Scott, Fundamentals of Genocide and Mass Atrocity Prevention (Washington, DC: United States Holocaust Memorial Museum, 2015).

Straus, Scott, The Order of Genocide: Race, Power, and War in Rwanda (Ithaca and London: Cornell University Press, 2006).

Straus, Scott. 2015. Making and Unmaking Nations: War, Leadership, and Genocide in Modern Africa. Ithaca: Cornell University Press. 
Straus, Scott. February 2014. Fundamentals of Genocide and Mass Atrocity Prevention. Washington, D.C.: United States Holocaust Memorial Museum.

Strous, Rael D., "Images in Psychiatry: Nazi Euthanasia of the Mentally Ill at Hadamar," American Journal of Psychiatry Vol. 163, No. 1 (January 2006).

Su, Yang, Collective Killings in Rural China during the Cultural Revolution (Cambridge: Cambridge University Press, 2011).

Su, Yang. 2011. Collective Killing in Rural China during the Cultural Revolution. New York: Cambridge University Press.

Szoldra, Paul "Here's What a Traffic Ticket Looks Like from The "Islamic State," Business Insider, September 4, 2014. URL: http://www.businessinsider.com/is-trafficticket-2014-9.

Tams, Christian J., Lars Berster, and Björn Schiffbauer, Convention on the Prevention and Punishment of the Crime of Genocide: A Commentary (Oxford: Hart Publishing, 2014).

Teitel, Ruti. 1996. "Judgment at The Hague." East European Constitutional Review 5(4) (Fall): 80-85.

The Associated Press, "Hugo Boss Acknowledges Link to Nazi Regime," The New York Times online, August 15, 1997. URL:

http://www.nytimes.com/1997/08/15/business/hugo-boss-acknowledges-link-to-naziregime.html.

The Avalon Project: Documents in Law, History and Diplomacy, Yale Law School Lillian Goldman Law Library, Accessed April 16, 2017, URL:

http://avalon.law.yale.edu/imt/count3.asp.

The Convention on the Prevention and Punishment of the Crime of Genocide, 1948. United Nations.

The Enough Project, "Lord's Resistance Army” Accessed: May 24, 2018. URL:

https://enoughproject.org/conflicts/lra).

The Holocaust: A Historical Summary (Washington, D.C.: U.S. Holocaust Memorial Museum, 1997).

The International Churchill Society. Speech titled, "The Atlantic Charter." URL: http://www.winstonchurchill.org 
Totten, Samuel, William S. Parsons, and Israel W. Charny, eds., Century of Genocide: Critical Essays and Eyewitness Accounts, Second Edition (New York and London: Routledge, 2004).

Traub, James, "Unwilling and Unable: The Failed Response to the Atrocities in Darfur," Occasional Paper Series (New York: Global Centre for the Responsibility to Protect, 2010).

Travis, Hannibal, "Genocide, Counterinsurgency, and the Self-Defense of UN Member States Before the International Criminal Court," UC Davis Journal of International Law \& Policy Vol. 22, No. 2, (Spring 2016).

Travis, Hannibal, "On the Original Understanding of the Crime of Genocide," Genocide Studies and Prevention 7:1 (Spring 2012).

Travis, Hannibal, comments in electronic communication with the author, March 2, 2018.

Travis, Hannibal, Genocide in the Middle East: The Ottoman Empire, Iraq, and Sudan. Durham, (NC: Carolina Academic Press, 2010).

Travis, Hannibal, Genocide, Ethnonationalism, and the United Nations: Exploring the Causes of Mass Killing Since 1945 (New York and London: Routledge, Taylor \& Francis Group, 2013).

Treisman, Daniel, "Why Putin Took Crimea: The Gamble in the Kremlin" Foreign Affairs May/June 2016. URL: https://www.foreignaffairs.com/articles/ukraine/2016-0418/why-putin-took-crimea.

Tucker, Robert C., ed. "The Eighteenth Brumaire of Louis Bonaparte," in The MarxEngels Reader, Second Edition (New York: W.W. Norton \& Company, 1978).

Tyner, James A., The Killing of Cambodia: Geography, Genocide and the Unmaking of Space (Burlington, VT: Ashgate, 2008).

Tyner, James A., The Killing of Cambodia: Geography, Genocide and the Unmaking of Space (Burlington, VT: Ashgate Publishing Limited, 2008).

Ulam, Adam B. 1973. Stalin: The Man and His Era. New York: The Viking Press.

U.S. Department of State, Daily Press Briefing Transcript, Friday, June 10, 1994. Accessed on April 13, 2017 from URL:

http://dosfan.lib.uic.edu/ERC/briefing/daily_briefings/1994/9406/940610db.html.

Ung, Loung, First They Killed My Father: A Daughter of Cambodia Remembers (New York: Harper Collins Publishers, 2000). 
Üngör, Uğur Ümit, "Studying Mass Violence: Pitfalls, Problems, and Promises," Genocide Studies and Prevention 7:1 (Spring 2012).

United Nations General Assembly Resolution 96(I), Fifty-Fifth Plenary Meeting December 11, 1946.

United Nations, Report on the Situation of Human Rights in Rwanda submitted by Mr. René Degni-Segui, Special Rapporteur of the Commission on Human Rights, under paragraph 20 of the resolution \#-3/1 of 25 May 1994, E/CN.4/1996/68, January 29, 1996.

United States Holocaust Memorial Museum, "Hermann Göring," accessed on April 18, 2017 from URL: https://www.ushmm.org/wlc/en/article.php?ModuleId=10007112.

Uvin, Peter, "Prejudice, crisis and genocide in Rwanda African Studies Review 40:2 (1997).

Uvin, Peter, Aiding Violence: The Development Enterprise in Rwanda (West Hartford, CT: Kumarian Press, 1998).

Valentino, Benjamin A. Final Solutions: Mass Killing and Genocide in the $20^{\text {th }}$ Century (Ithaca: Cornell University Press, 2004).

Valentino, Benjamin A. 2004. Final Solutions: Mass Killing and Genocide in the $20^{\text {th }}$ Century. Ithaca: Cornell University Press.

Valentino, Benjamin, Paul Huth, and Dylan Balch-Lindsay, “'Draining the Sea': Mass Killing and Guerrilla Warfare," International Organization Vol 58., (2004) 375-407.

van Acker, Frank, "Uganda and the Lord's Resistance Army: The New Order No one Ordered" African Affairs Vol. 103. No. 412, (2004).

Verdeja, Ernesto, "On Situating the Study of Genocide within Political Violence," Genocide Studies and Prevention 7:1 (Spring 2012) 81-88.

Verdery, Katherine, The Political Lives of Dead Bodies: Reburial and Postsocialist Change (New York: Columbia University Press, 1999).

Verlinden, Lies, The Aftermath of a Dark Past: Forensic archeology and memorialization of the 1994 Genocide against the Tutsi (Dissertation, 2015-2016) cites Anil Aggrawal, "Mass Murder" in Payne-James, J.J., Byard, R.W. Corey, T.S., and Henderson, C. (eds). Encyclopedia of Forensic and Legal Medicine Vol. 3, pp. 216.

Vickery, Michael, "Democratic Kampuchea: Themes and Variations," in David P. Chandler and Ben Kiernan eds., Revolution and Its Aftermath in Kampuchea: Eights 
Essays (New Haven: Yale University Southeast Asia Studies Monograph Series No. 25, 1983).

Vickery, Michael, Cambodia: 1975-1982 (Boston, MA: South End Press, 1985).

Vinci, Anthony, "The Strategic Use of Fear by the Lord's Resistance Army" Small Wars and Insurgencies Vol. 16, No. 3 (2005).

von Joeden-Forgey, Elisa, "Genocidal Masculinity" in Adam Jones eds., New Directions in Genocide Research (London and New York: Routledge, 2012).

Waller, James, Becoming Evil: How Ordinary People Can Commit Genocide and Mass Killing (New York: Oxford University Press, 2002).

Wallimann, Isidor \& Michael N. Dobkowski, Genocide in the Modern Age: Etiology and Case Studies of Mass Death (New York: Greenwood Press, 1987).

Warren, Mary Anne, Gendercide: The Implications of Sex Selection (Totowa, NJ: Rowman \& Allanheld, 1985). Martin Shaw. 2007. What is Genocide? Malden, MA: Polity Press.

Wasserstein, David J. Black Banners of ISIS: The Roots of the New Caliphate (New Haven and London: Yale University Press, 2017).

Watts, Franklin, Civil War and Genocide (Hachette Children's Group, forthcoming in 2018); Marcia Esparza, Henry R. Huttenbach, and Daniel Feierstein, eds., State Violence and Genocide in Latin America: The Cold War Years (New York: Routledge, 2010).

Weiner, Amir, Making Sense of War: The Second World War and the Fate of the Bolshevik Revolution (Princeton, NJ: Princeton University Press, 2001).

Weirich, Paul, "Economic Rationality" in Alfred R. Mele and Piers Rawling eds., The Oxford Handbook of Rationality (Oxford, Oxford University Press, 2004).

Weissman, George and Duncan Williams eds., The Balkan Wars 1912-13: The War Correspondence of Leon Trotsky (New York: Monad Press, 1980).

Weitz, Eric D. "Genocide and the rigor of philosophy: a comment on Paul Boghossian," Journal of Genocide Research 12:1-2 (2010) 101-104.

Weitz, Eric D. A Century of Genocide: Utopias of Race and Nation (Princeton: Princeton University Press, 2003).

Welaratna, Usha, Beyond the Killing Fields: Voices of Nine Cambodian Survivors in America (Stanford, CA: Stanford University Press, 1993). 
Winestone, Martin, The Holocaust Sites of Europe: An Historical Guide (London and New York: I.B. Tauris, 2015).

Wohlgelernter, Maurice, “Hitler's Willing Executioners: Daniel Jonah Goldhagen Interviewed by Maurice Wohlgelernter" Society Vol. 34, Iss. 2 (1992).

Yathay, Pin, Stay Alive, My Son (Ithaca and London: Cornell University Press, 1987).

Yitzhak Arad, Belzec, Sobibor, Treblinka: The Operation Reinhard Death Camps (Bloomington and Indianapolis: Indiana University Press, 1999).

Zarrow, Peter, China in War and Revolution, 1895-1949 (London and New York: Routledge, 2005).

Zimbardo, Philip, The Lucifer Effect: Understanding How Good People Turn Evil (New York: The Random House Publishing Group, 2008). 


\section{APPENDIX A}

\section{First Wave Alternative Definitions of Genocide}

Raphael Lemkin (1944)

Nuremburg Trial

Proceedings Volume 1

Indictment: Count 3

(1945)

UN General Assembly

Resolution 96(I) (1946)

UN Genocide

Convention (1948)

Pieter Drost (1959)
"[Genocide is] the destruction of a nation or of an ethnic group." 1019

"They conducted deliberate and systematic genocide, viz., the extermination of racial and national groups, against the civilian populations of certain occupied territories in order to destroy particular races and classes of people and national, racial, or religious groups, particularly Jews, Poles, and Gypsies and others."1020

"Genocide is a denial of the right of existence of entire human groups, as homicide is the denial of the right to live of individual human beings; such denial of the right of existence shocks the conscience of mankind, results in great losses to humanity in the form of cultural and other contributions represented by these human groups, and is contrary to moral law and to the spirit and aims of the United Nations. ... The General Assembly, therefore, affirms that genocide is a crime under international law... whether the crime is committed on religious, racial, political or any other grounds are punishable." ${ }^{1021}$

"[Genocide is] acts committed with intent to destroy, in whole or in part, a national, ethnical, racial, or religious group as such." 1022

"Deliberate destruction of physical life of individual human beings by reason of their membership of any human collectivity as such." 1023

${ }^{1019}$ Lemkin, Axis Rule in Occupied Europe, 79.

1020 The Avalon Project: Documents in Law, History and Diplomacy, Yale Law School Lillian Goldman Law Library, Accessed April 16, 2017, URL: http://avalon.law.yale.edu/imt/count3.asp.

${ }^{1021}$ United Nations General Assembly Resolution 96(I), Fifty-Fifth Plenary Meeting December 11, 1946, p. 188-189.

1022 The Convention on the Prevention and Punishment of the Crime of Genocide, 1948, Article 2, p. 1.

1023 Pieter Drost, The Crime of State: Penal Protection for Fundamental Freedoms of Persons and Peoples (A.W. Sythoff, 1959); Scott Straus, "Contested meanings and conflicting imperatives: A conceptual analysis of genocide," Journal of Genocide Research 3:3 (2001) 350. 
Vahakn Dadrian (1975)

Leo Kuper (1981)

Jack Nusan Porter (1982)

Yehuda Bauer (1984)
"Genocide is the successful attempt by a dominant group, vested with formal authority and/or with preponderant access to the overall resources of power, to reduce by coercion or lethal violence the number of a minority group whose ultimate extermination is held desirable and useful and whose respective vulnerability is a major factor contributing to the decision for genocide."1024

"Genocide, in terms of the perspective of this study, is a crime against a collectivity, taking the form of massive slaughter, and carried out with explicit intent. As a crime against a collectivity, it sets aside the whole question of individual responsibility; it is a denial of individuality." 1025

"Genocide is the deliberate destruction, in whole or in part, by a government or its agents, of a racial, sexual, religious, tribal or political minority. It can involve not only mass murder, but also starvation, forced deportation, and political, economic and biological subjugation. Genocide involves three major components: ideology, technology, and bureaucracy/organization."1026

Bauer makes a conceptual distinction between "genocide" and "holocaust." "[Genocide is] the planned destruction, since the mid-nineteenth century, of a racial, national, or ethnic group as such, by the following means: (a) selective mass murder of elites or parts of the population; (b) elimination of national (racial, ethnic) culture and religious life with the intent of 'denationalization', (c) enslavement, with the same intent; (d) destruction of national (racial, ethnic) economic life, with the same intent; (e) biological decimation through the kidnapping of children, or the prevention of normal family life, with the same intent... [Holocaust is] the planned physical annihilation, for

\footnotetext{
1024 Vahakn N. Dadrian, “A Typology of Genocide.” International Review of Modern Sociology 5:2., (1975) 201.

1025 Kuper, Genocide, 86.

1026 Jack Nusan Porter, The Genocidal Mind: Sociological and Sexual Perspectives (University Press of America, 1982), 7.
} 
John L. Thompson and Gail A. Quets (1987)

Isidor Wallimann \& Michael N. Dobkowski (1987)

Tony Barta (1987)

Henry Huttenbach (1988)

Barbara Harff and Ted Robert Gurr (1988) ideological or pseudo-religious reasons, of all the members of a national, ethnic, or racial group."1027

"Genocide is the extent of destruction of a social collectivity by whatever agents, with whatever intentions, by purposive actions which fall outside the recognized conventions of legitimate warfare." 1028

"Genocide is the deliberate, organized destruction, in whole or in large part, of racial or ethnic groups by a government or its agents. It can involve not only mass murder but also forced deportation (ethnic cleansing), systematic rape, and economic and biological subjugation." 1029

"My conception of a genocidal society-as distinct from a genocidal state-is one in which the bureaucratic apparatus might officially be directed to protect innocent people but in which a whole race is nevertheless subject to remorseless pressures of destruction inherent in the very nature of the society." 1030

"Genocide is any act that puts the very existence of a group in jeopardy." 1031

"The promotion and execution of policies by a state or its agents which result in the deaths of a substantial portion of a group." 1032

\footnotetext{
${ }^{1027}$ Adam Jones, Genocide: A Comprehensive Introduction, Second Edition. (New York: Routledge, Taylor \& Francis Group, 2011) 17.

${ }^{1028}$ Ibid, 17.

${ }^{1029}$ Isidor Wallimann \& Michael N. Dobkowski, Genocide in the Modern Age: Etiology and Case Studies of Mass Death (New York: Greenwood Press, 1987), x.

1030 Tony Barta, Relations of Genocide: Land and Lives in the Colonization of Australia (Los Angeles, CA: Sage, 2008), 239-240.

${ }^{1031}$ Henry Huttenbach, "Locating the Holocaust on the genocide spectrum" Holocaust and Genocide Studies 3:3 (1988) 289-304.

1032 Barbara Harff and Ted Robert Gurr, "Toward Empirical Theory of Genocides and Politicides: Identification and Measurement of Cases Since 1945" International Studies Quarterly 32:3 (September 1988) 360 .
} 
Helen Fein (1988)

Ervin Staub (1989)

Frank Chalk and Kurt Jonassohn (1990)

Helen Fein (1990)

Robert Melson (1992)
"Genocide is a series of purposeful actions by a perpetrator(s) to destroy a collectivity through mass or selective murders of group members and suppressing the biological and social reproduction of the collectivity. This can be accomplished through the imposed proscription or restriction of reproduction of group members, increasing infant mortality, and breaking the linkage between reproduction and socialization of children in the family or group of origin. The perpetrator may represent the state of the victim, another state, or another collectivity."1033

"An attempt to exterminate a racial, ethnic, religious, cultural, or political group, either directly through murder or indirectly by creating the conditions that lead to the group's destruction."1034

"A form of one-sided mass killing in which a state or other authority intends to destroy a group, as that group and membership in it are defined by the perpetrator." 1035

"Sustained purposeful action by a perpetrator to physically destroy a collectivity directly or indirectly, through interdiction of the biological and social reproduction of group members, sustained regardless of the surrender or lack of threat offered by the victim."

"A public policy mainly carried out by the state whose intent is the destruction in whole or in part of a social collectivity or category, usually a communal group, class, or a political faction." 1037

\footnotetext{
1033 OMICS International, Accessed April 10, 2017, URL: http://research.omicsgroup.org/index.php/ Genocide_definitions\#cite_note-FOOTNOTEKieserSchaller2001-13.

1034 Ervin Staub, The Roots of Evil: The Origins of Genocide and Other Group Violence (Cambridge, UK: Cambridge University Press, 1989).

1035 Frank Chalk and Kurt Jonassohn, The History and Sociology of Genocide: Analyses and Case Studies (New Haven: Yale University Press, 1990).

1036 Scott Straus, “Contested meanings and conflicting imperatives: A conceptual analysis of genocide,” 352.

${ }^{1037}$ Robert Melson, Revolution and Genocide: On the Origins of the Armenian Genocide and the Holocaust (University of Chicago Press, 1992).
} 
Steven Katz (1994)

Israel Charny (1994)

Irving Louis Horowitz (1996)

Yehuda Bauer (1999)

Levon Chorbajian (1999)

Rome Statute (2002)
"Actualization of the intent, however successfully carried out, to murder in its totality any national, ethnic, racial, religious, political, social, gender, or economic group, as these groups are defined by the perpetrator, by whatever means." 1038

"Mass killing of substantial numbers of human beings, when not in the course of military action against the military forces of an avowed enemy, under conditions of the essential defenselessness and helplessness of victims." 1039

"Genocide is herein defined as a structural and systematic destruction of innocent people by a state bureaucratic apparatus [emphasis in original] .... Genocide means the physical dismemberment and liquidation of people on largescales, an attempt by those who rule to achieve the total elimination of a subject people." 1040

"A purposeful attempt to eliminate an ethnicity or a nation, accompanied by the murder of large numbers of the targeted group." 1041

"Initiated by authoritarian states, premediated, involving great cruelty, and bringing about large numbers of deaths in absolute terms and deaths as a percentage of target." 1042

"For the purpose of this Statute, 'genocide' means any of the following acts committed with intent to destroy, in whole or in part, a national, ethnical, racial or religious group, as such: (a) Killing members of the group;

(b) Causing serious bodily or mental harm to members of the group; (c) Deliberately inflicting on the group conditions of life calculated to bring about its physical

\footnotetext{
1038 Steven T. Katz, The Holocaust in Historical Context, Vol. 1: The Holocaust and Mass Death Before the Modern Age (New York: Oxford University Press, 1994) 131.

1039 Israel Charny, "Toward a generic definition of genocide," in George Andreopoulos, ed., Genocide: Conceptual and Historical Dimensions (Philadelphia: University of Pennsylvania Press, 1994).

1040 Jones, Genocide: A Comprehensive Introduction, 19.

1041 Scott Straus, “Contested meanings and conflicting imperatives: A conceptual analysis of genocide,” 352.

1042 Levon Chorbajian and George Shirinian, ed., Studies in Comparative Genocide (New York: St. Martin’s Press, Inc., 1999) xxi.
} 
destruction in whole or in part; (d) Imposing measures intended to prevent births within the group; (e) Forcibly transferring children of the group to another group." 1043

Manus Midlarsky (2005) "Genocide is understood to be the state-sponsored systematic mass murder of innocent and helpless men, women, and children denoted by a particular ethnoreligious identity, having the purpose of eradicating this group from a particular territory." 1044

Mark Levene (2005) "Genocide occurs when a state, perceiving the integrity of its agenda to be threatened by an aggregate population defined by the state as an organic collectivity, or series of collectivities - seeks to remedy the situation by the systematic, en masse physical elimination of that aggregate, in toto, or until it is no longer perceived to represent a threat." 1045

Jacques Sémelin (2005) "I will define genocide as that particular process of civilian destruction that is directed at the total eradication of a group, the criteria by which it is identified being determined by the perpetrator." 1046

Daniel Chirot and Clark McCauley (2006)

"A genocidal mass murder is politically motivated violence that directly or indirectly kills a substantial proportion of a targeted population, combatants and noncombatants alike, regardless of their age or gender."1047

\footnotetext{
${ }^{1043}$ Rome Statute of the International Criminal Court, Text of the Rome Statute circulated as document A/CONF.183/9 of 17 July 1998 and corrected by process-verbaux of 10 November 1998, 12 July 1999, 30 November 1999, 8 May 2000, 17 January 2001 and 16 January 2002. The Statute entered into force on 1 July 2002, Accessed April 16, 2017, p. 3.

${ }^{1044}$ Manus I. Midlarsky, The Killing Trap: Genocide in the Twentieth Century (Cambridge: Cambridge University Press, 2005).

1045 Jones, Genocide: A Comprehensive Introduction, 19.

1046 Jacques Sémelin, Purify and Destroy: The Political Uses of Massacre and Genocide, Translated from the French by Cynthia Schoch (New York: Columbia University Press, 2005).

${ }^{1047}$ Daniel Chirot and Clark McCauley, Why Not Kill Them All? The Logic and Prevention of Mass Political Murder (Princeton: Princeton University Press, 2006) 17.
} 
Martin Shaw (2007)

Jacques Semelin (2007)

Donald Bloxham (2009)
"[Genocide is] a form of violent social conflict, or war, between armed power organizations that aim to destroy civilian social groups and those groups and other actors who resist this destruction." 1048

"Genocide is a particular process of civilian destruction that is directed at the total eradication of a group, the criteria by which it is identified being determined by the perpetrator." 1049

"[Genocide is] the physical destruction of a large portion of a group in a limited or unlimited territory with the intention of destroying that group's collective existence." 1050

${ }^{1048}$ Martin Shaw, What is Genocide? (Malden, MA: Polity Press, 2007).

1049 Jacques Semelin, Purify and Destroy: The Political Uses of Massacre and Genocide (New York: Columbia University Press, 2007), 340.

${ }^{1050}$ Jones, Genocide: A Comprehensive Introduction, 20. 


\begin{abstract}
APPENDIX B
Second Wave Sub-Categories of Genocide

Auto-genocide

Biological Genocide

Decolonization Genocide

Despotic Genocide

"The curious idea of "auto-genocide" is applied principally to the Cambodian case. The term's strangeness is that, taken literally, it suggests self-destruction: and while individuals often take their own lives, collective suicide is much rarer - and no one has suggested that this has happened in any genocide, including in Cambodia. The term has been defined instead as "mass killing of members of the group to which the perpetrators themselves belong." 1051

"The prevention of births within a group...broadly conceived as encompassing castration, compulsory abortion, sterilization and the segregation of the sexes." 1052

Classified as "genocide following upon decolonization of a two-tier structure of domination." Leo Kuper, "Types of genocide and mass murder."1053

"Genocides are typical in "new" states, among peoples sharing little or no common history or traditions... Upon independence the "strong man" from the leading tribe exerts his will on unwilling minorities, often using strong measures to preempt oppositional moves."1054
\end{abstract}

\footnotetext{
${ }^{1051}$ Martin Shaw, What is Genocide? (Malden, MA: Polity Press, 2007) 76-77; Also see William A. Schabas, Genocide in International Law (Cambridge: Cambridge University Press, 2000) 119-120.

1052 Ad Hoc Committee, supra note 3, Sixth Session, 13th meeting, at 11, 14 UN Doc E/AC.25/SR.13 (1948) (Mr. Ordonneau, Fr.) cited in Matthew Lippman, "A road map to the 1948 Convention on the Prevention and Punishment of the Crime Genocide," Journal of Genocide Research 4:2 (2002), 182.

1053 In Israel Charny, ed., Toward the Understanding and Prevention of Genocide: Proceedings of the International Conference on the Holocaust and Genocide (Boulder: Westview Press, 1984), pp 32-47.

1054 Harff and Gurr, "Toward Empirical Theory of Genocides and Politicides," 362; Helen Fein, "Scenarios of Genocide: Models of Genocide and Critical Responses," in Toward the Understanding and Prevention of Genocide, ed., Israel W. Charny (Boulder, CO: Westview Press, 1984).
} 
Developmental Genocide Are "often economically exploited, they offer little resistance to "progress" and are perceived as standing in the way of further development" both in terms of territory and ideology. ${ }^{1055}$

Ecological (or)

Destruction Genocide

Genocidal Massacre

Hegemonial Geno-/

Politicide

Ideological Genocide
Described as "genocide as a result of ecological destruction and abuse." Some cases include the Germany targeting of the Herero population in Southwest Africa, hole in the ozone layer, poisoning of water supplies, and air and nuclear pollution. ${ }^{1056}$

These are smaller scale genocides, such as in Tiananmen Square or Sri Lanka. Israel Charny, "Toward a generic definition of genocide."1057

"Mass murders which occur when distinct ethnic, religious, or national groups are being forced to submit to central authority, for example during the consolidation of power by a new state or in the course of national expansion." 1058

Preexisting prejudices and stereotypes are exploited by the dominant group. Minority or marginalized groups are scapegoated or discriminated against, which is consistent with the prevailing ideology of elite rulers. ${ }^{1059}$

1055 Harff and Gurr, "Toward Empirical Theory of Genocides and Politicides," 362; Fein, Helen. 1984. "Scenarios of Genocide: Models of Genocide and Critical Responses." In Toward the Understanding and Prevention of Genocide, ed. Israel W. Charny. Boulder, CO: Westview Press.

1056 Israel Charny, "Toward a generic definition of genocide," in George Andreopoulos, ed., Genocide: Conceptual and Historical Dimensions (Philadelphia: University of Pennsylvania Press, 1994), p 91.

1057 In George Andreopoulos, ed., Genocide: Conceptual and Historical Dimensions (Philadelphia: University of Pennsylvania Press, 1994), p 91.

1058 Harff, Barbara and Ted Robert Gurr. 1988. "Toward Empirical Theory of Genocides and Politicides: Identification and Measurement of Cases Since 1945. International Studies Quarterly, Vol. 32, No. 3, p. 359371 on p. 363.

1059 Harff, Barbara and Ted Robert Gurr. 1988. "Toward Empirical Theory of Genocides and Politicides: Identification and Measurement of Cases Since 1945. International Studies Quarterly, Vol. 32, No. 3, p. 359371 on p. 362; Fein, Helen. 1984. "Scenarios of Genocide: Models of Genocide and Critical Responses." In Toward the Understanding and Prevention of Genocide, ed. Israel W. Charny. Boulder, CO: Westview Press. 
Indigenous Genocide

Institutional Genocide

Intentional Genocide

Latent Genocide
Genocides enacted against indigenous populations, for example, during colonization the Americas, Australia, and Africa. ${ }^{1060}$

“...was the major source of politically sanctioned mass murder in the ancient and medieval worlds. The massacre of men, the enslavement of women and children, and, often, the razing of the countryside, were universal aspects of conquest: genocide was embedded in the very notion of warfare." See Roger Smith, "State power and genocidal intent." 1061

Simply put, the intentional, straightforward hunting and murder of a population, for example, Nazi atrocities and genocidal campaigns against the Jews, Roma and homosexuals. Israel Charny, "Toward a generic definition of genocide." 1062

Whatever the scope and its intensity, latent genocide is a by-product or result of goals in the pursuit of which unintended consequences develop. Military operations, tactical or strategic in character, may engulf civilian populations. Peacetime relocations or wartime deportations of large segments of a minority group may exact heavy tolls and casualties, depleting the ranks of the affected group. When the dominant group persists in these violent efforts and refrains from obviating the adverse, unintended consequences, such behavior may be termed genocidal." 1063

\footnotetext{
${ }^{1060}$ Leo Kuper, “Types of genocide and mass murder," in Israel Charny, ed., Toward the Understanding and Prevention of Genocide: Proceedings of the International Conference on the Holocaust and Genocide (Boulder: Westview Press, 1984), pp 32-47.

1061 In Levon Chorbajian and George Shirinian, eds, Studies in Comparative Genocide (New York: St. Martin's Press, 1999), pp 5-8. See also Roger Smith, "Human destructiveness and politics: the twentieth century as an age of genocide," in Isidor Walliman and Michael Dobkowski, eds, Genocide and the Modern Age: Etiology and Case Studies of Mass Death (Westport: Greenwood Press, 1987), pp 23-27.

1062 in George Andreopoulos, ed., Genocide: Conceptual and Historical Dimensions (Philadelphia: University of Pennsylvania Press, 1994), p 91.

1063 Vahakn N. Dadrian. 1975. “A Typology of Genocide.” International Review of Modern Sociology. Vol. 5., No. 2., p. 205-206.
} 
Monopolistic Genocide

Optimal Genocide

Partial Genocide

Repressive Geno-/

Politicides

Retributive Geno-/

Politicide
"Most genocide prior to the twentieth century was external - it was exacted of groups that lived outside one's territorial boundaries. There are some important exceptions - most of them connected with religious persecution - but for the most part genocide was directed outwards: its goals were conquest and colonial expansion." For example, the colonial conquest against indigenous peoples around the world. See Roger Smith, "State power and genocidal intent." 1064

"Here, the destruction process is massive, relatively indiscriminate in terms of victims' age, sex and other categories, is sustained in duration, and aims at the total obliteration of the victim group. Consequently, the scale of casualties is maximum and victimization is optimal." 1065

In these cases, mass murder is used to elicit order and/or alter the identity and political beliefs of a group, not necessarily its complete destruction. ${ }^{1066}$

"Mass murders targeted at political parties, factions, and movements because they are engaged in some form of oppositional activity." 1067

"...These genocides occur in the wake of decolonization or of war and conquest. Typically, two or more people vie for power in the same domain, neither accepting the other's domination. One evident difference between retributive and despotic genocides is that in the former, ethnic

\footnotetext{
1064 in Levon Chorbajian and George Shirinian, eds, Studies in Comparative Genocide (New York: St. Martin's Press, 1999), pp 5-8. See also Roger Smith, "Human destructiveness and politics: the twentieth century as an age of genocide," in Isidor Walliman and Michael Dobkowski, eds, Genocide and the Modern Age: Etiology and Case Studies of Mass Death (Westport: Greenwood Press, 1987), pp 23-27.

1065 Vahakn N. Dadrian. 1975. “A Typology of Genocide.” International Review of Modern Sociology. Vol. 5., No. 2., p. 210.

1066 Beachler, Donald W. 2011. The Genocide Debate: Politics, Academics, and Victims. Palgrave Macmillan US; Robert Melson, 'Modern genocide in Rwanda: ideology, revolution, war, and mass murder in an African state', in Robert Gellately and Ben Kiernan (eds), The Specter of Genocide: Mass Murder in Historical Perspective (Cambridge: Cambridge University Press 2003).

1067 Harff, Barbara and Ted Robert Gurr. 1988. "Toward Empirical Theory of Genocides and Politicides: Identification and Measurement of Cases Since 1945. International Studies Quarterly, Vol. 32, No. 3, p. 359371
} 


\section{Revolutionary Geno-/ Politicide}

Terroristic Genocide

Total Genocide

Utilitarian Genocide animosities are entrenched prior to the takeover or establishment of the new regime." 1068

"Mass murders of class or political enemies in the service of new revolutionary ideologies."1069

The authors do not use this term directly but they write, "to spread terror among real or potential enemies," thus I termed it "terroristic genocide" to describe their definitive sub-category. ${ }^{1070}$

Compared to partial genocides, the complete destruction of a population or group is desired, for example, as in the Holocaust, Rwanda or Armenian genocides. ${ }^{1071}$

"Limited in scope because of such limited objectives as economic advantages, demographic considerations, military designs, etc. utilitarian genocide involves regional massacres en masse, segmental cross-country massacres, or limiting massacres to such categories as sex, age, religion, and so forth. The character of objectives is matched by the limited capabilities of the perpetrator vis-àvis a resistant prone victim, whose vulnerability is further reduced by internal dissension besetting the perpetrator group." 1072

\footnotetext{
1068 Harff, Barbara and Ted Robert Gurr. 1988. "Toward Empirical Theory of Genocides and Politicides: Identification and Measurement of Cases Since 1945. International Studies Quarterly, Vol. 32, No. 3, p. 359371 on p. 362; Vahakn N. Dadrian. 1975. "A Typology of Genocide." International Review of Modern Sociology. Vol. 5., No. 2., p. 207; Fein, Helen. 1984. "Scenarios of Genocide: Models of Genocide and Critical Responses." In Toward the Understanding and Prevention of Genocide, ed. Israel W. Charny. Boulder, CO: Westview Press.
}

1069 Harff, Barbara and Ted Robert Gurr. 1988. "Toward Empirical Theory of Genocides and Politicides: Identification and Measurement of Cases Since 1945. International Studies Quarterly, Vol. 32, No. 3, p. 359371.

${ }^{1070}$ Frank Chalk and Kurt Jonassohn, The History and Sociology of Genocide: Analyses and Case Studies (New Haven: Yale University Press, 1990), pp 44-45.

${ }^{1071}$ Beachler, Donald W. 2011. The Genocide Debate: Politics, Academics, and Victims. Palgrave Macmillan US.

1072 Vahakn N. Dadrian. 1975. “A Typology of Genocide.” International Review of Modern Sociology. Vol. 5., No. 2., p. 209. 
Wealth Genocide

Xenophobic Genocide
The authors do not use this term directly but they write, "to acquire wealth," therefore I use the term "wealth genocide" to capture their meaning. ${ }^{1073}$

"Mass murders of ethnically, religiously, or nationally distinct groups in the service of doctrines of national protection or social purification which define the victims as alien and threatening." 1074

${ }^{1073}$ Frank Chalk and Kurt Jonassohn, The History and Sociology of Genocide: Analyses and Case Studies (New Haven: Yale University Press, 1990), pp 44-45.

${ }^{1074}$ Harff, Barbara and Ted Robert Gurr. 1988. "Toward Empirical Theory of Genocides and Politicides: Identification and Measurement of Cases Since 1945. International Studies Quarterly, Vol. 32, No. 3, p. 359371. 


APPENDIX C
Third Wave Substitutive Terms for Genocide
"...atrocity crimes [are] a grouping of crimes that includes
genocide but is not confined to that particular crime... [and]
atrocity crimes describe a basket of particularly heinous
crimes that are suitable for criminal prosecution before
international tribunals and national courts and for which
states and certain non-state organizations and groups should
be held responsible. Atrocity crimes also are collectively
executed crimes of such magnitude and destructive character
as to be particularly prominent and logically inconsistent
with the protection of human rights and the maintenance of
international peace and security in an increasingly
interdependent and sophisticated global society."1075
The targeting of social classes for their destruction or
annihilation. ${ }^{2}$
"This concept shares three basic premises with genocide or
"This
mass killing. First, the criteria for becoming a victim are not
about deeds but rather with membership in a group. Second,
the killing must be intentional, which is distinct from acts of
endangerment that carry no goal of killing in the first place.
Using torture to elicit confessions, for example, may cause
significant numbers of deaths. Third, the number of victims
must reach a certain level. This aspect is very much related
to the first premise regarding membership: Individuals are
rounded up because they are members of a particular group,
which by definition results in a collective of victims. I
replace the word mass with collective, for the analysis of
units smaller than a country as a while, for example, county.
Collective killings may occur in smaller areas without
meeting the criteria suggested by [Benjamin]
Valentino..."1077

1075 David Scheffer, "Genocide and Atrocity Crimes" Genocide Studies and Prevention: An International Journal 1:3 (2006) 230, 238.

${ }^{1076}$ Martin Shaw. 2007. What is Genocide? Malden, MA: Polity Press, p. 72.

${ }^{1077}$ Su, Yang. 2011. Collective Killing in Rural China during the Cultural Revolution. New York: Cambridge University Press, p. 13. 
Communalism

Cultural Genocide

Culturecide

Dekamegamurders

Democide

Ethnic Cleansing
Stuart Stein references communalism in his article "Genoand other cides." Communalism generally refers to violence in and between localized neighborhoods, villages, districts or cells, though I have found no clear definition within the literature that has been operationalized. ${ }^{1078}$

"Violence may be implied via threats to secure compliance with the wishes of the dominant group. However, with actual compliance violence becomes superfluous and thus the resulting minority-group behavior is in a Simmelian sense voluntary, the option for non-compliance not having been exercised. In consequence, non-violent genocide may ensue. Massive conversions in the religion of the dominant group, systematic adoption of a large category of offsprings [sic] of the victim group, discriminating practices to promote deethnicisation, in brief, the deliberate structuring of preemptive assimilation may be involved." 1079

The process of denationalization or the attempt to remove cultural, social and political associations of one group from the national or local context. ${ }^{1080}$

“...deka- means ten or tens; mega- means millions." Rummel uses these as a category to refer to episodes where the victim casualties reach tens of millions of people. ${ }^{1081}$

"The murder of any person or people by a government, including genocide, politicide, and mass murder." ${ }^{1082}$

Can be related or overlapped with genocide but defined to a specific geographic territory. ${ }^{1083}$

\footnotetext{
${ }^{1078}$ Stuart Stein, "Geno- and other cides: a cautionary note on knowledge accumulation” Journal of Genocide Research 4:1 (2002) 39-63.

1079 Vahakn N. Dadrian. 1975. “A Typology of Genocide." International Review of Modern Sociology. Vol. 5., No. 2., p. 205.

${ }^{1080}$ Stein, Stuart. 2005. "Conceptions and Terms: Templates for the Analysis of Holocausts and Genocides," Journal of Genocide Research Vol 7., No. 2., p. 171-203, on p. 180.

${ }^{1081}$ Rummel, R.J. 1990. Death by Government. New Brunswick, NJ: Transaction Publishers, p. xviii.

${ }^{1082}$ Rummel, 1990, p. 31.

1083 Naimark, Norman M. 2001. Fires of Hatred: Ethnic Cleansing in Twentieth Century Europe. Harvard University Press.
} 
Ethnocide

Extremely Violent

Societies

Femicide (gynocide)

Gendercide

Holocaust (Shoah)
This term first developed by Raphael Lemkin to reflect the killing of members who belong to a particular ethnic group, perhaps, a more specific term then genocide. ${ }^{1084}$

"By extremely violent societies, I mean formations where various population groups become victims of massive physical violence, in which, acting together with organs of the state, diverse social groups participate for a multitude of reasons." 1085

"...implie[s] that only one gender category, women, [are] targets of gender-selective killings."1086

"...the deliberate extermination of persons of a particular sex (or gender)." "1087 This is a gender-neutral term, meaning, either sex may be the recipients of violence.

This term is exclusively used to reference Nazi atrocities against the Jewish people during the Second World War and sometimes is expanded to include other marginalized populations marked for death (e.g., homosexuals, Roma, Jehovah Witnesses, Freemasons, and political opponents). The word Holocaust has become synonymous with genocide in many popular circles that it bears mentioning here, though it is not a substitutive for genocide, but perhaps may qualify as a sub-category of, in that is referencing a particular victim group. In addition to the term Holocaust, others have referred to this particular genocide as the "Final Solution" or "Shoah," Hebrew for "catastrophe." 1088

\footnotetext{
${ }^{1084}$ Lemkin, Axis Rule, p. 79.

1085 Gerlach, Christian. 2010. Extremely Violent Societies: Mass Violence in the Twentieth-Century World. Cambridge: Cambridge University Press, p. 1.

1086 Stuart Stein, “Geno- and other cides: a cautionary note on knowledge accumulation” Journal of Genocide Research 4:1 (2002) 39.

${ }^{1087}$ First coined by Mary Anne Warren, Gendercide: The Implications of Sex Selection (Totowa, NJ: Rowman \& Allanheld, 1985). Martin Shaw. 2007. What is Genocide? Malden, MA: Polity Press, p. 67.

1088 Alan S. Rosenbaum, Is the Holocaust unique? Perspectives on Comparative Genocide (Boulder, CO: Westview Press Inc., 1996); Josh Fleet, "History and Meaning of the Word 'Holocaust': Are We Still Comfortable with This Term?" The Huffington Post, March 28, 2012, http://www.huffingtonpost.com/2012/01/27/the-word-holocaust-history-and-meaning_n_1229043.html.
} 
Infanticide

Man-Made Deaths

Mass Annihilation

Mass Atrocity

Mass Categorical

Violence

Mass Death
The systematic killing of children, particularly, infants. ${ }^{1089}$

Similar to communalism and infanticide, "man-made deaths," to the author's knowledge, has not been operationalized in the same manner as other such terms, but substantially used to reference the large-scale killing of persons by perpetrators. ${ }^{1090}$

"Regimes that resort to mass annihilation do so mostly under conditions of advanced compartmentalization, a separation of the regime's people from the target group in every sense and at every level. The targeted people must first be demarcated, they must be registered, and they must be isolated and made the object of a persistent campaign of vilification and dehumanization. The rest of the population is incited to hate and loathe them."1091

Some describe a mass atrocity as 5,000 civilian deaths within a 12-month period (Alex Bellamy) and others have lowered the threshold to 1,000 civilian deaths per year (Jay Ulfelder and Benjamin Valentino). ${ }^{1092}$

Is "large-scale, group-selective violence... In particular, group-selective violence typically requires perpetrators to command effective territorial domination over target populations. Local actors in general possess the information necessary to identify and sort target populations." ${ }^{1093}$

Katz defines genocide and mass death as the "actualization of the intent, however successfully carried out, to murder in its totality any national, ethnic, racial, religious, political,

\footnotetext{
${ }^{1089}$ Stuart Stein, "Geno- and other cides: a cautionary note on knowledge accumulation" Journal of Genocide Research 4:1 (2002) 39-63.

${ }^{1090}$ Stuart Stein, "Geno- and other cides: a cautionary note on knowledge accumulation" Journal of Genocide Research 4:1 (2002) 39-63.

${ }^{1091}$ De Swaan, Abram. 2015. The Killing Compartments: The Mentality of Mass Murder. New Haven: Yale University Press, p. 119.

1092 Bellamy, Alex. 2011. "Mass Atrocities and Armed Conflict: Links, Distinctions, and Implications for the Responsibility to Protect." Stanley Foundation, URL: http://www.stanleyfoundation.org/resources. $\mathrm{cfm}$ ?ID=445. Ulfelder, Jay, and Benjamin Valentino. 2008. "Assessing the Risks of State-Sponsored Mass Killing." Political Instability Task Force, Washington, DC.

Straus, Scott. 2015. Making and Unmaking Nations: War, Leadership, and Genocide in Modern Africa. Ithaca: Cornell University Press, p. 17.
} 
Mass Killing

Mass Murder

Mass Political Murder

Mass Violence

Massacre social, gender or economic group, as these groups are defined by the perpetrator, by whatever means."1094

Defined "as the intentional killing of a massive number of noncombatants." This definition has three characteristics: the mass killing must be intentional, there must be at least 50,000 victims within a five-year period, and the victims must be civilians or non-combatants. ${ }^{1095}$

"The indiscriminate killing of any person or people by a government."1096

Is episodes where "categories were used to target victims; the aim was political. That is, a certain group was deemed to pose a threat of some sort to those in control, and therefore it has to be eliminated." 1097

“...means widespread physical violence against noncombatants, that is, outside of immediate fighting between military or paramilitary personnel."1098

The term "massacre" has been overly used within the academic and popular discourse. However, this term carries a deep and complex meaning. Here are two understandings of the term from Jacques Semelin. “.... a state or non-state power resorts to massacre in order to overcome its position of weakness, to ensure influence over the people and to extend its own power." 1099

"The notion of "massacre" gives rise to various problems of definition. Etymologically, the word derives from the popular Latin "matteuca," meaning "bludgeon." The word contains the sense of "butchery," designating both the

\footnotetext{
${ }^{1094}$ See Steven Katz, The Holocaust in Historical Context: The Holocaust and Mass Death before the Modern Age, Volume I (New York: Oxford University Press, 1994): 131.

1095 Valentino, Benjamin A. 2004. Final Solutions: Mass Killing and Genocide in the $20^{\text {th }}$ Century. Ithaca: Cornell University Press, p. 10-14.

1096 Rummel, R.J. 1990. Death by Government. New Brunswick, NJ: Transaction Publishers, p. 31. Chirot, Daniel and Clark McCauley. 2006. Why Not Kill Them All? The Logic and Prevention of Mass Political Murder. Princeton: Princeton University Press, p. 14-15.

1098 Gerlach, Christian. 2010. Extremely Violent Societies: Mass Violence in the Twentieth-Century World. Cambridge: Cambridge University Press, p. 1.

1099 Jacques Semelin, "Toward a vocabulary of massacre and genocide" Journal of Genocide Research 5:2 (2003) 195.
} 
Megamurders

Megapogroms abattoir and the butcher's shop. From the eleventh century on "massacre" becomes synonymous with the putting to death of animals and human beings. Historically, therefore, massacre appears to suppose a relationship of proximity between the assassin and his victim, based as it is on a technique of murder that applies also to animals. In this way the practice of slitting the throat, emerging from peasant know-how, is found to be used, for example, in the massacres of civil wars whether in Algeria or Greece.10 If, therefore, massacre implies a type of "one on one," must we then conclude that other technologies of murder, that imply distance between the killer and his victim, cannot be properly spoken of as "massacres"? [...] Alain Corbin uses the term to describe the killing of a single individual! A careful reading of his text shows, nonetheless, that its author hesitates in employing this term, preferring often to resort to that of "sacrifice." Or is it rather the case, following the "Guatemalan Commission of Human Rights," that massacre begins with the death of at least three individuals? The proposition that massacre is determined by numbers also appears to be arguable. But how many victims constitute a massacre? Stathis Kalyvas proposes the figure of at least 10 deaths while at the same time recognising that such an estimation is arbitrary."1100

This category is one below dekamegamurders, where victim casualties reach millions (one to ten). ${ }^{1101}$

"The role of the central state is much less visible. The initiators are local notables, politicians, gangsters, clerics. The perpetrators are not in the service of the regime, and they too, are local men. Because this is little organization and minimal logistic support, the killing episodes in any given location last only a few days or weeks at most."1102

\footnotetext{
${ }^{1100}$ Jacques Semelin, “In consideration of massacres” Journal of Genocide Research 3:3 (2001) 378-379.

${ }^{1101}$ Rummel, R.J. 1990. Death by Government. New Brunswick, NJ: Transaction Publishers, p. xviii.

1102 De Swaan, Abram. 2015. The Killing Compartments: The Mentality of Mass Murder. New Haven: Yale University Press, p. 190.
} 
Multicide

Murderous Cleansing

Nuclear Omnicide

Pogrom

Political Genocide

Politicide
"Mass murder - the killing of four or more victims at one time and location - has become increasingly common of late... Mass murder is one of several forms of multicide..."1103

"Murderous cleansing is modern - it is "the dark side of democracy." It results where the demos (democracy) is confused with the ethnos (the ethnic group). Danger arises where two rival ethnonational movements each claims "its own" state over the same territory." 1104

Omnicide is meant to describe "the destruction of all life." Omnes, meaning "towards all" or "everyone," and-cide, meaning "to kill.".1105

Typically, small-scale mob violence directed at a group of individuals sharing similar social characteristics. ${ }^{106}$

Describes the murder of individuals for political reasons or membership in a group, that is, perceived to challenge status quo. ${ }^{1107}$

"In politicides the victim groups are defined primarily in terms of their hierarchical position or political opposition to the regime and dominant groups." 1108

\footnotetext{
${ }^{1103}$ Found in Lies Verlinden, The Aftermath of a Dark Past: Forensic archeology and memorialization of the 1994 Genocide against the Tutsi (Dissertation, 2015-2016) cites Anil Aggrawal, "Mass Murder" in PayneJames, J.J.; Byard, R.W.; Corey, T.S., and Henderson, C. (eds). Encyclopedia of Forensic and Legal Medicine Vol. 3, pp. 216.

1104 Mann, Michael. 2005. The Dark Side of Democracy: Explaining Ethnic Cleansing. Cambridge: Cambridge University Press.

${ }^{1105}$ Lifton, Robert Jay and Erik Markusen. 1991. The Genocidal Mentality: Nazi Holocaust and Nuclear Threat. Basic Books, p. 3.

${ }^{1106}$ Stein lists "pogrom" in his article but does not provide a definition. Therefore, the generic definition is included above. Stuart Stein, "Geno- and other cides: a cautionary note on knowledge accumulation" Journal of Genocide Research 4:1 (2002) 39.

${ }^{1107}$ Beth Van Schaack uses this term as a synonym for politicide. Beth Van Schaack, "The Crime of Political Genocide: Repairing the Genocide Convention's Blind Spot," The Yale Law Journal 106:7 (May 1997): 2259-2291.

${ }^{1108}$ Harff, Barbara and Ted Robert Gurr. 1988. "Toward Empirical Theory of Genocides and Politicides: Identification and Measurement of Cases Since 1945." International Studies Quarterly Vol. 32, No. 3, p. 359-371 on p. 360; Martin Shaw. 2007. What is Genocide? Malden, MA: Polity Press, p. 69.
} 
Population Cleansing

Proto-Genocide

State Crime

Urbicide

Vigilantism

Zones of Violence
Is "the planned, deliberate removal from a certain territory of an undesirable population distinguished by one or more characteristics such as ethnicity, religion, race, class, or sexual preference." 1109

"This concept adds clarity to studies of cultural genocide by helping to distinguish between situations where a collective identity is under violent attack and situations of full-blown genocide." 1110

Similar to communalism, state crime lacks a clear definition within political science. It has been employed to classify incidents of state-directed violence. ${ }^{1111}$

This is the destruction of urban centers and urban life. "Urban centers, originally fortified centres of power, have always been pivotal to warfare, and modern war has targeted industrial and capital cities with bombs and nuclear missiles." 1112

Violence perpetrated by persons acting in an extra-judicial capacity against members of a group. ${ }^{1113}$

"This approach implies a geographical focus and aims to examine the violent exchange between several population groups in so-called borderlands in the longue durée. This framework's innovative potential lies in its transnational orientation. The dynamics of mass violence can only be adequately understood if broader regional contexts are taken into account. Refugee flows, famines, epidemics, and environmental degradation are phenomena that cross

\footnotetext{
1109 Developed by Andrew Bell-Fialkoff quoted in Martin Shaw. 2007. What is Genocide? Malden, MA: Polity Press, p. 50.

${ }^{1110}$ Christopher Powell and Amarnath Amarasingam. 2017. "Atrocity and Proto-Genocide in Sri Lanka" in Scott W. Murray, ed., Understanding Atrocities: Remembering, Representing, and Teaching Genocide. Calgary, Alberta, Canada: University of Calgary Press, p. 19.

1111 Stuart Stein, “Geno- and other cides: a cautionary note on knowledge accumulation" Journal of Genocide Research 4:1 (2002) 39-63.

1112 Martin Shaw. 2007. What is Genocide? Malden, MA: Polity Press, p. 75.

1113 Stuart Stein, "Geno- and other cides: a cautionary note on knowledge accumulation" Journal of Genocide Research 4:1 (2002) 39-63.
} 
national borders and often contribute to political tensions and outbreaks of mass violence." 1114

1114 Quoted text from Dominik J. Schaller, "From Lemkin to Clooney: The Development and State of Genocide Studies" Genocide Studies and Prevention: An International Journal 6:3 (2011) 252; also see the following: Mark Levene, "Creating a Modern 'Zone of Genocide': The Impact of Nation- and StateFormation on Eastern Anatolia, 1878-1923,’ Holocaust and Genocide Studies 12:3 (1998): 393-433. 
VITA

ZACHARY A. KARAZSIA

2018-present Limited Term Assistant Professor

Georgia Southern University, Statesboro, GA

$2017-2018$

Fellow

University Graduate School, Florida International University, Miami, FL

$2015 \quad$ Fellow

American Political Science Association Africa Workshop, Nairobi, Kenya

2012-2013 Research Associate

HPW Associates, LLC, Pittsburgh, PA

Bachelor of Arts (with high distinction) in Global Studies, 2009

The Pennsylvania State University, Berks College

Major: Contemporary African Politics and History

Bachelor of Arts (with high distinction) in Communication Arts \& Sciences, 2009

The Pennsylvania State University, Berks College

Honor Society: Lambda Pi Eta, Inducted 2009

Master of International Development, 2012

University of Pittsburgh, Graduate School of Public and International Affairs

Major: Human Security

Master of Arts in Political Science, 2016

Florida International University

Major: Comparative Politics Minor: International Relations

Ph.D. in Political Science, (ABD), expected 2019

Florida International University

Dissertation: Genocide in the Modern Age: State-Society Relations in the Making of Mass

Political Violence, 1900-2015 


\section{PUBLICATIONS AND PRESENTATIONS}

Karazsia, Zachary A. "An Unfulfilled Promise: The Genocide Convention and the Obligation of Prevention.” Journal of Strategic Security 11:4 (2018): DOI: 10.1080/2156 5503.2018.1529604.

Karazsia, Zachary A. "A Long Way to Peace: Identities, Genocide, and State Preservation in Burma, 1948-2016" (with Adam Howe). Politics, Groups, and Identities (2018). DOI: 10.1080/21565503.2018.1529604.

Karazsia, Zachary A. "Evaluating the "Success" of Disarmament, Demobilization, and Reintegration Programs: The Case of Congo-Brazzaville," Journal of Interdisciplinary Conflict Science, (2015) 1:2, pp. 1-32.

Karazsia, Zachary A. "Developing Hearts and Land: A Case Study of Reconciliation, Governance, and Development in Rwanda" in Sustainable Development and Human Security in Africa: Governance as the Missing Link, Louis A. Picard, Terry F. Buss, Taylor Seybolt, and Macrina Lelei, eds., Boca Raton, FL: CRC Press, Taylor and Francis Group, 2015, pp. 233-248.

Picard, Louis A. and Zachary A. Karazsia, "The Truman Administration's Foreign Aid Legacy: From the Cold War to the War on Terrorism" in The Foreign Aid Legacy of Harry S. Truman, eds. Michael Divine and Ray Geselbracht. Kirksville, MO: Truman State University Press, The Truman Legacy Series vol. 10, 2015, pp. 11-32.

Karazsia, Zachary A. "Generalized Chaos: An A Posteriori Analysis of the Dynamics of Post-Conflict State Building,” Pitt Policy Journal, (Spring 2012, Vol. 4), pp. 131-149.

Karazsia, Zachary A. Review of Vahakn N. Dadrian and Taner Akçam, Judgment at Istanbul: The Armenian Genocide Trials, New York: Berghahn Books, 2011, Insight Turkey 17:4, forthcoming.

Karazsia, Zachary A. Review of Noah R. Bassil, Fall 2015. The Post-Colonial State and Civil War in Sudan: The Origins of Conflict in Darfur, London: I.B. Tauris \& Co Ltd, 2013, Journal of Third World Studies.

Karazsia, Zachary A. "Peace Inc.? The Role of Contractors in International Peace Operations," The Ford Institute for Human Security, University of Pittsburgh, April 11. 2012.

Karazsia, Zachary A. "African Security and the African Command," The Ford Institute for Human Security, University of Pittsburgh, September 16, 2011. 